\title{
補 冊
}

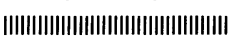

\section{第20回 RI インビトロ検査全国コントロールサーベイ 成績報告要旨 $(1998 \text { 年 })^{\dagger}$}

(社)日本アイソトープ協会医学・薬学部会インビトロテスト専門委員会 ${ }^{\dagger+}$

113-8941 東京都文京区本駒込 2-28-45

\begin{abstract}
Key Words : control survey, radioimmunoassay, immunoradiometric assay, growth hormone, somatomedin $\mathrm{C}$, follicle stimulating hormone, luteinizing hormone, prolactin, thyroid stimulating hormone, triiodothyronine, free triiodothyronine, thyroxine, free thyroxine, thyroxine binding globulin, calcitonin, insulin, C-peptide, glucagon, gastrin, testosterone, free testosterone, estradiol, progesterone, $\beta$ human chorionic gonadotropin, $17 \alpha$ hydroxyprogesterone, aldosterone, cortisol, dehydroepiandrosterone sulfate, renin, immunoglobulin E, digoxin, $\alpha$-fetoprotein, carcinoembryonic antigen, tissue polypeptide antigen, CA125, CA19-9, CA15-3, prostatic acid phosphatase, prostate specific antigen, $\beta_{2}$-microglobulin, ferritin, neuron specific enolase
\end{abstract}

\section{1.はじめに}

正確な臨床検査值は疾患の診断，治療効果の 判定，治療指針などに不可欠であるが，実際の 臨床の場において種々の測定キットが使用され ているため，必ずしも同じ標準的な臨床検査值 で判断されているわけではない。日本アイソ

\footnotetext{
${ }^{\dagger}$ Summary, The 20th Quality Control Survey for Radioisotope in vitro Tests in Japan, 1998. Subcommittee for Radioisotope in vitro Test, Medical and Pharmaceutical Committee, Japan Radioisotope Association, 2-28-45, Honkomagome, Bunkyo-ku, Tokyo 113-8941, Japan.

"t委員長 紫芝 良昌 虎の門病院 副委員長 小林 久江 群馬大学生体調節研究所 委 員 市原 清志 川崎医科大学医学部 高坂 唯子 京都大学医学部附属病院 清水多恵子 虎の門病院

立花 克彦 神奈川県立こども

医療センター

對馬 敏夫 東京女子医科大学 星野 稔 静岡県立大学薬学部 森 三樹雄 獨協医科大学越谷病院
}

トープ協会医学・薬学部会インビトロテスト専 門委員会は, 全国のインビトロ検査実施施設に おいて施行されている測定の実際を知るため, 1978年より毎年コントロールサーベイを行って きた。これによって現在のインビトロ検査の質 の向上を図ることを目的としたものである。 今回は1998年度に行われた「第 20 回 RI イ ンビトロ検查全国コントロールサーベイ」の集 計結果について報告する。

\section{2. 対象亡方法}

\section{$2 \cdot 1$ 調查対象施設}

今回のサーベイに参加した施設は，1998年12 月の時点で RI インビトロ検査を実施している 全国 285 の病院, 診療所, 衛生検查所, 試薬 メーカーのうち参加の申し込みを得た 143 施設 である（参加率 $50.2 \%$ )。参加施設の内訳は表 1 に示すように国・公立大学病院 20 , 私立大学 病院 18 , 国立病院 8, 公立病院 13 , 民間病院 
21 , 衛生検查所 41 , 試薬メーカー 22 であっ た。

\section{$2 \cdot 2$ 調查対象項目}

今回調查対象としたのは下垂体機能検查関連 物質 6 項目 $(\mathrm{GH}, \mathrm{FSH}, \quad \mathrm{LH}, \quad$ プロラクチン, TSH，ソマトメジンC／I GF-I ），甲状腺機能 検查関連物質 5 項目 $\left(T_{3}\right.$, Free $T_{3}, T_{4}, F$ ree $T_{4}$, $\mathrm{TBG}$ ), 副甲状腺機能関連物質 1 項目 (カルシ トニン), 消化管・膵機能関連物質 4 項目 (1 ンスリン, C-ペプチド，グルカゴン，ガストリ ン), 性腺・胎盤機能検查関連 5 項目 ( $\beta \mathrm{HCG}$, テストステロン, Free テストステロン，エスト ラジオール, プロゲステロン), 副腎機能検查関 連 4 項目（コルチゾール,アルドステロン, $17 \alpha$ ヒドロキシプロゲステロン, DHEA-S), 腎・血 圧調節機能検查関連 1 項目 (レニン定量), 免 疫グロブリン 1 項目 ( $\mathrm{IgE}$ ), 薬物 1 項目 (ジゴ キシン), 腫瘍関連抗原 11 項目 (AFP, CEA, TPA, CA125, CA 19-9, CA 15-3, PAP, PA, $\beta_{2}-$ マ イクログロブリン, フェリチン, NSE) である。 本年度新たに NSE が加わり全項目数は 39 で, 各項目についての参加施設数は表 1 に示すとお りである。延べ項目数は 2471 で，うち非アイ ソトープ（non-RI）法による測定は延べ 1208 項目であった。

\section{$2 \cdot 3$ 検查試料}

各項目ごとに濃度の異なる 2 ないし 3 試料を 調製し，凍結乾燥品として参加施設に送付し た。試料は各施設において液体サンプルに再調 製されて測定に供された。資料の保存・調製に 当たっては添付された条件を厳守するように依 頼した。なお，試料の蛋白組成は七ト血清とほ ぼ同様であった（表 2 )。また，表 3 に示した 14 項目については同時再現性, 日差再現性, 凍結・融解反復の影響, 溶解後の測定值の経時 的变動について検討した (表 $4-$ 表 6 )。

\section{$2 \cdot 4$ 測定方法}

上記の各試料の濃度測定は従来ラジオイムノ アッセイ（RIA）やイムノラジオメトリック アッセイ（IRMA）によるあのが主流であった が, 近年は酵素, 蛍光, 化学発光物質など非了 イソトープ (non-RI) を用いた方法が急激に普 及している。今回のサーベイでもnon-RI を用 いた測定は $49.0 \%$ で前回を上回った。non-RI の種類は, EIA (enzyme immunoassay), ELISA (enzyme-linked immunosorbent assay), LPIA (latex photometric immunoassay), PAMIA (particle mediated immunoassay), FIA (fluoro immunoassay), FPIA (fluorescence polarization immunoassay), NIA (nephrometric mmunoassay), LAT (latex turbidimetric immunoassay), CLIA (chemiluminescent immunoassay), ECLIA (electrochemiluminescent immunoassay) など多様であっ た。測定は各試料 2 重測定で行われた。

\section{$2 \cdot 5$ 測定結果の解析}

\section{$2 \cdot 5 \cdot 1$ 測定結果の処理}

各項目, 各キットごとに検体測定値の平均値 $(M)$ ，標準偏差 $(\mathrm{SD})$, 変動係数 $(\mathrm{CV} \%)$ を計 算した。また， 6 施設以上の参加が得られたも のについては平均值から $\pm 2 S D$ 以上はずれる あのを除外し，新たに $M, \mathrm{SD}, \mathrm{CV} \%$ を算出し， 表 7 の下欄に示した。さらにこれらの測定値か ら，一元配置分散分析を用いてキット内变動係 数 (施設間変動係数), キット間変動係数 (試薬 間変動係数) を計算するとともに，ここ数年間 の変化について検討した（表 8 )。

計算方法は下記のとおりである。

測定キット数： $a$

各測定キットを利用した施設： $n_{i}$

キット別の平均值: $\bar{X}_{i}$ 総平均: $\tilde{X}$

$S_{\text {粗キット間 }}^{2}=\frac{\sum_{i}^{a} n_{i} \cdot\left(\bar{X}_{i}-\tilde{X}\right)^{2}}{a-1}$ 


$$
S_{\text {キット内 }}^{2}=\frac{\sum_{i}^{a} \sum_{j}^{n_{i}}\left(X_{i j}-\bar{X}_{i}\right)^{2}}{\sum_{i}^{a}\left(n_{i}-1\right)}
$$

となる。ここで粗キット間 CV\% と純粋なキッ ト間 CV\%の関係は

$$
S_{\text {粗キット間 }}^{2}=S_{\text {キット内 }}^{2}+n_{0} \cdot S_{\text {キット間 }}^{2}
$$

$n_{0}$ は一つの測定法当たりの平均の参加施設 に相当し， $N$ をデー夕総数とすると，

$$
n_{0}=\frac{1}{a-1} \cdot\left(N-\frac{\sum_{i}^{a} n_{i}{ }^{2}}{N}\right)
$$

となる。これから，キット内 $\mathrm{CV} \%$ を取り除い た純粋なキット間 CV\%の大きさ $\left(S^{2}\right.$ キット間)

$$
S_{\text {キット間 }}^{2}=\frac{S_{\text {粗キット間 }}^{2}-S_{\text {キット内 }}^{2}}{n_{0}}
$$

となる。

なお，これらの計算は，あらかじめ分布の両 端の極端な值を 3SD 1 回切断除外して行った。

$2 \cdot 5 \cdot 23$ 検体試料の測定值の一貫性

同一キットで 3 試料の測定が 4 施設以上で行 われたキットについて, 試料の測定値の関係を 調べた（図 1 )。各施設の 3 試料の測定值（各試 料 2 重測定の時はその平均値) $X_{\mathrm{A}}, X_{\mathrm{B}}, X_{\mathrm{C}}$ を, 3 試料の総平均值（全キットの測定值の平均） $\bar{X}_{\mathrm{A}}, \bar{X}_{\mathrm{B}}, \bar{X}_{\mathrm{C}}$ に対して直線回帰して，その傾きを 調べた。

なお，各平均值は $\pm 2 \mathrm{SD}$ 以上偏位したデー 夕は除外して再計算した值を用いた。なお，本 要旨では具体例を省略した。

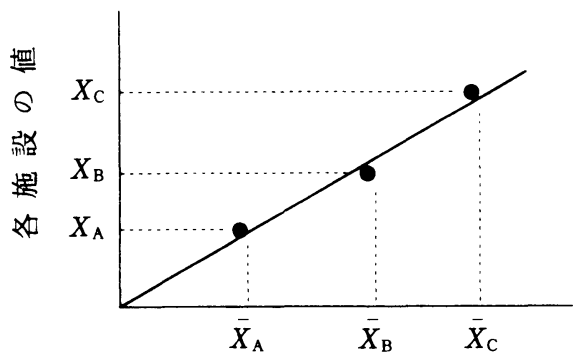

総平均值

図 13 测定值の配置の直線性

\section{$2 \cdot 5 \cdot 3$ 検量線の検討}

参加施設が 4 施設以上あったキットについて 標準曲線を比較した。横軸に濃度を，縦軸には $B / T$ ないし $B / B_{0}$ で示した。なお， $B_{0}$ は RIA， その他の競合法ではゼロ濃度における結合能 を, IRMA その他の非競合法では最大濃度に おける結合能を用いた。本要旨では具体例を省 略した。

\section{3. 成 績}

項目別の測定結果の一覧を表 7 に示す。ま た，表 8 にキット内・キット間における変動係 数，表 9,10 にそれぞれキット内・キット間 $\mathrm{CV} \%$ の年次変化，表 11 にキットごとの CV\% の年次推移および表 12 にキットの標準物質に ついて示す。

\section{$3 \cdot 1$ 同時および日差再現性}

表 3 に示した 14 項目で同時再現性を検討し た結果， 3 種類の検体 (PA のみ 2 検体) で $\mathrm{CV}$ $\%$ は全項目とも $10 \%$ 以下であった。低濃度検 体の 3 項目を除き，ほとんどが $5 \%$ 以下であっ た。

また，表 4 に示すように，異なる日に 5 回施 行した測定での CV\% は Free テストステロン 以外はおおむね $10 \%$ 以下であった。

\section{$3 \cdot 2$ 凍結融解の影響}

上記の検体について 5 回まで凍結融解を繰り 返した結果を表 5 に示した。いずれの項目であ 凍結融解での大きな影響は見られなかった。

\section{$3 \cdot 3$ 検体融解後の経時的変化}

凍結保存, 融解後の $4{ }^{\circ} \mathrm{C}$ 保存および室温保 存した検体について保存に伴う測定値の経時的 変化について検討した結果を表 6 に示す。凍結 保存の場合にはガストリンで経時的な測定值の 低下が認められたが，その他の項目では 10 日 間で測定値には変化が認められなかった。 $4{ }^{\circ} \mathrm{C}$ 保存の場合にはカルシトニン, C-ペプチド, 
ガストリン, PA（PSA）で測定値の低下が認 められた。室温保存の場合には, 上記 4 項目で は $4{ }^{\circ} \mathrm{C}$ 保存の場合よりあさらに測定値の低下 は顕著であった。また, インスリンあ室温保存 で測定値の低下が見られた。なお，グルカゴン に関しては室温保存で経時的な測定值の上昇が 認められた。

\section{$3 \cdot 4$ 項目別の測定結果}

今回測定の対象となった 39 項目について, 個別の集計結果を表 7 に示す。

以下に各項目について概略を述べる。

\section{$3 \cdot 4 \cdot 1 \quad \mathrm{GH}$}

参加施設数 49,2 種類の IRMA キット (41 施設), 1 種類の EIA キット ( 5 施設) および 1 種類の CLIA キット（3 施設）が使用された。 3 キットにおけるキット内 CV\% は昨年と同様 に $10 \%$ 以下であり，ほぼ満足できる結果と思 われる。キット間 CV\%は 3 検体とも $20 \%$ を 超えていた昨年度に比して改善されているが, RIA キットの使用がなかったためと思われる。 昨年度む指摘のあった， $\mathrm{GH}$ キット「第一」が 他のキットに比べて高値を示す傾向は変わって いない。

\section{$3 \cdot 4 \cdot 2$ ソマトメジン C}

参加 施設数 18,2 種類の IRMA キット（15 施設)， 1 種類の RIA キット ( 3 施設) が使用 された。キット内変動は 8.9-11.5\% であった が, キット間 CV\% は 20.8-39.4\%であった。 例年よりは改善されているものの良好な結果と はいえない。一昨年度の検討で, 測定值の乘離 は検体試料（凍結乾燥品）による可能性が高い ものと思われる。

\section{$3 \cdot 4 \cdot 3 \mathrm{FSH}$}

参加 施設数は 89, 標準物質 WHO 2nd IRP 78/549 に準拠した 3 種類の IRMA キット（35 施設)， 7 種類の EIA キット (25 施設)， 3 種類 の CLIA キット ( 7 施設), 1 種類の FIA キッ 卜 ( 2 施設), 1 種類の ECLIA キット ( 2 施設 $)$ であった。また，標準物質 WHO 2nd IRP 94/
632 に準拠する 2 種類の CLIA キット（18 施 設）が使用された。キット内 CV\%は 3 検体で $5 \%$ 前後で安定しているが，RIキット間 CV\% は 26.0-34.6\% で, 例年に比して大きくなって いる。これはアレグロ FSH キットの低値傾向 が強まったためと思われる。

$3 \cdot 4 \cdot 4 \mathrm{LH}$

参加 施設数は 89 , 標準物質 WHO 1 st IRP 68/40 に準拠する 3 種類の IRMA キット（35 施設)， 4 種類の EIA キット (21 施設)， 2 種類 の CLIA キット（6 施設）であった。また，標 準物質 WHO 2nd IRP 80/552 に準拠する 4 種 類の CLIA キット (20 施設), 2 種類の EIA キット ( 4 施設), 1 種類の FIA キット（2 施 設), 1 種類の ECLIA キット（1 施設）が使用 された。キット内 CV\%は，いずれのキットで も $7 \%$ 前後で問題はない。しかし，同一の標準 品を使用していながら， RIキット間 CV\% は 20.9-43.6\% ट改善の傾向は見られない。昨年 度指摘された低值傾向のキットは本年度もその ままであった。

$3 \cdot 4 \cdot 5$ プロラクチン

参加施設数 83, 標準物質が NIH VLS\# 4 に 準拠する 1 種類の IRMA キット ( 4 施設), WHO 1st IRP $75 / 504$ に準拠する 2 種類の IRMA キット (27 施設), WHO 2nd IRP 83/ 562 に準拠するそれぞれ 1 種類の IRMA キッ 卜 ( 2 施設), EIA キット ( 2 施設 $),$ WHO 3rd IRP 84/500 に準拠するキット 13 種類 (48 施 設）が使用された。 RI キット間 CV\% は例年高 く，本年度は $77 \%$ となっている。Ab ビーズ プロラクチン ‘栄研’ と $\mathrm{E}$ テスト [TOSOH] II PRL の両キットは, 同一の標準品を使用して いるにも関わらず，測定值が倍以上になってい る。WHO 3rd IRP 84/500 に準拠するキットの うち DPC・イムライズプロラクチンの測定值 が特に低值であった。標準品が異なっても単位 はすべて $\mathrm{ng} / \mathrm{ml}$ の重量表示であるから，測定 值を近づける努力が欲しい。 


\section{$3 \cdot 4 \cdot 6$ TSH}

参加施設数 124,5 種類の IRMA キット（45 施設), 1 種類の RIA キット ( 3 施設), 8 種類 の $\mathrm{EIA}$ キット (26 施設), 5 種類の CLIA キッ 卜 (45 施設), 1 種類の ECLIA キット ( 4 施 設), 1 種類の ELISA キット（1 施設）という 21 種類の測定キットでの報告があった。昨年 度に比してキット内 CV\%が大きくなったキッ トが増えた。 RI キット間 CV\% は $10 \%$ 前後で 従来の成績と差はなかった。

\section{$3 \cdot 4 \cdot 7 \quad \mathrm{~T}_{3}$}

参加施設数 100,7 種類の RIA キット $(39$ 施 設), 8 種類の EIA キット (21 施設)，4 種類の CLIA キット (37 施設), 1 種類の ECLIA キッ ト（3 施設）が使用された。キット内 CV\%は 低濃度検体で 10\% を超えるキットあ見られた が，中・高濃度検体では $10 \%$ 以下であった。 また， RI キット間 CV\%あ，それぞれ 9.1 , $9.9,11.2 \%$ と満足できる結果であった。

\section{$3 \cdot 4 \cdot 8 \quad$ Free $\mathrm{T}_{3}$}

参加施設数 112, 4 種類の RIA キット (42 施 設), 8 種類の EIA キット (20 施設), 6 種類の CLIA キット (45 施設), 1 種類の ECLIA キッ 卜 ( 4 施設)，1 種類の ELISA キット（1 施設） が使用された。キット内 CV\% は各濃度とも 7 \%前後と良好であったが，キット間 CV\%は， ここ数年間高值のままで改善されていない。測 定值はキットごとにまちまちで, 2 倍から 4 倍 の開きがある。日本 DPC 社の 2 製品は特に低 值を示している。

\section{$3 \cdot 4 \cdot 9 \quad \mathrm{~T}_{4}$}

参加施設数 99,7 種類の RIA キット (37 施 設)， 5 種類の $\mathrm{EIA}$ キット (11 施設)，4 種類の CLIA キット (37 施設), 1 種類の ECLIA キッ ト ( 3 施設), 2 種類の FPIA キット (10 施設), 1 種類の LPIA キット（1 施設）が使用された。 低値検体のキット内 CV\% で 10\% を超える キットがあったが， RI キット間 CV\% は 1.9 $7.6 \%$ で満足できる結果であった。特に目立つ 低値や高值の報告はない。
$3 \cdot 4 \cdot 10 \quad$ Free $T_{4}$

参加施設数 121,6 種類の RIA キット $(37$ 施 設), 8 種類の EIA キット (24 施設)， 5 種類の CLIA キット (45 施設)， 1 種類の ECLIA キッ ト ( 4 施設)，1 種類の ELISA キット（1 施設） が使用された。一部のキットで変動が大きい報 告ああるが，キット内 CV\% は 10\% 以下でお おむね良好である。しかし，キット間 CV\%は $24.3,50.1,32.9 \%$ ときわめて大きい值を示し, この傾向はここ数年改善されていない。

\section{$3 \cdot 4 \cdot 11$ TBG}

参加施設数 26,2 種類の RIA キット $(24$ 施 設)，1 種類の EIA キット ( 1 施設)，1 種類の CLIA キット（1 施設）が使用された。キット 内 CV\% は各検体とも $10 \%$ 以下で良好であっ た。キット間 CV\%は 10.4-17.3\%であった。 両者の値屯数年間変化していない。

\section{$3 \cdot 4 \cdot 12$ カルシトニン}

参加施設数 23,4 種類の RIA キットが使用 された。キット内，キット間 CV\%とも大き い。特にカルシトニンキット「第一」は，キッ 卜内 CV\%が 3 検体とも $20 \%$ 以上であった。 この傾向は昨年と同様で改善されていない。

\section{$3 \cdot 4 \cdot 13$ インスリン}

参加施設数 107,5 種類の RIA キット (36 施 設), 1 種類の IRMA キット (35 施設), 5 種類 の $\mathrm{EIA}$ キット (23 施設), 2 種類の CLIA キッ 卜 $(6$ 施設), 1 種類の PAMIA キット ( 2 施 設)，1 種類の ELISA キット ( 3 施設)，1 種類 の LPIA キット（2 施設）が使用された。キッ ト内 CV\% (10\% 以下)，キット間 CV\% (15\% 前後) とも昨年度より改善され本年度む維持し ている。本年度むルミノマスター「IRI」は他 キットに比べて高值を示したが，昨年度行った 血清サンプルでの検討により，原因は検体試料 （凍結乾燥品）にあると思われる。

\section{$3 \cdot 4 \cdot 14$ C一ペプチド}

参加施設数 68,2 種類の RIA キット (58 施 設)，1 種類の EIA キット ( 8 施設)，1 種類の CLIA キット（2 施設）が使用された。キット 
内 CV\% はおおむね 10\% 以下で良好であるが， $\mathrm{RI}$ キット間 CV\% が $22.5-28.9 \%$ となお高 く, この傾向は数年変わらない。昨年度, 他の キットの測定値よりも $20-30 \%$ 高値を指摘さ れた C-ペプチドキット「第一」III は, 本年度 は各検体とも最も低值を示した。

\section{$3 \cdot 4 \cdot 15$ グルカゴン}

参加施設数 13,1 種類の RIA キットのみで 測定された。キット内 CV\% はいずれる $10 \%$ 前後で昨年度と同様の結果であった。

\section{$3 \cdot 4 \cdot 16$ ガストリン}

参加施設数 24,1 種類の RIA キットのみで 測定された。キット内 CV\% はそれぞれ 15.7, $6.4,7.6 \%$ であった。この結果は最近 5 年間の 結果と差はなかった。

\section{$3 \cdot 4 \cdot 17$ テストステロン}

参加施設数 27,3 種類の RIA キット (23 施 設), 3 種類の CLIA キット (11 施設), 1 種類 の EIA キット ( 2 施設), 1 種類の ECLIA キット（1 施設）が使用された。検体における キット内 CV\%は14.6, 4.4, 11.7\% であった。 低值検体と高值検体にばらつきの大きいキット が 2, 3 あるためのようである。キット間 CV $\%$ は，いずれの検体む $20 \%$ 以上でこの傾向は 数年来変わらないため, 昨年血清サンプルを使 用して検討を行った結果, 大きな測定値の変動 はなかったので検体試料の影響と思われる。

\section{$3 \cdot 4 \cdot 18$ Free テストステロン}

参加施設数 9 , すべて1 種類の RIA キットが 使用された。キット内 CV\% は低濃度検体で $16.8 \%$ であったが, 他の検体は $10 \%$ 以下で あった。これは例年と同じであった。

$3 \cdot 4 \cdot 19$ エストラジオール

参加施設数 64,4 種類の RIA キット (31 施 設), 4 種類の CLIA キット (19 施設)， 5 種類 の EIA キット (12 施設), 1 種類の FIA キット （2 施設）が使用された。キット内 CV\%は $11.6,10.3,9.8 \%$ であった。この傾向は例年ど おりであった。キット間 CV\% は，54.0，29.6， $48.2 \%$ と昨年度よりはやや改善されたものの,
高値を示した。

$$
3 \cdot 4 \cdot 20 \text { プロゲステロン }
$$

参加施設数 57,3 種類の RIA キット（29 施 設), 4 種類の CLIA キット (21 施設)， 5 種類 の EIA キット（ 7 施設）が使用された。キット 内 $\mathrm{CV} \%$ は 3 検体とも $10 \%$ 以下で良好であっ た。しかし，キット間 CV\%は 27.6, 17.6, $23.7 \%$ であり, 昨年までの傾向と変わらない。

$3 \cdot 4 \cdot 21 \quad 17 \alpha$-ヒドロキシプロゲステロン

参加施設数 6,1 種類の RIA キットのみの報 告であった。今年は EIA のキットの参加はな かった。昨年低值検体が非常に低值で測られ， キット内 CV\% は $71.9 \%$ であったが，今年は 低値検体の結果報告はなかった。中・高檤検体 は，これまでで一番高いキット内 $\mathrm{CV} \%$ の $27.4,23.8 \%$ という結果であった。

\section{$3 \cdot 4 \cdot 22 \cdot 1 \quad \beta \mathrm{HCG} 1$}

参加施設数 12,1 種類の IRMA キット（9 施設)， 1 種類の CLIA キット（ 3 施設）の報告 があった。キット内 CV\% は 10\% 前後で低值 の割には良好であった。キット間 CV\%あ $8.2,3.8 \%$ と良好であった。

\section{$3 \cdot 4 \cdot 22 \cdot 2 \quad \beta \mathrm{HCG} 2$}

参加施設数 14,5 種類の EIA キットが使用 された。キット内 CV\%，キット間 CV\%とも $10 \%$ 以下で良好な結果であった。

\section{$3 \cdot 4 \cdot 23$ アルドステロン}

参加施設数 51,3 種類の RIA キットが使用 された。キット内 CV\% は $10 \%$ 前後で良好で あるが，キット間 CV％は，29.8，10.1， $10.5 \%$ であった。アルドステロン・リアキッ ト II の低値検体の報告が他のキットに比べ高值 であるためにキット間 CV\% が大きくなってし まったと考えられる。中，高値検体のキット間 $\mathrm{CV \%}$ は昨年より改善された。

$$
3 \cdot 4 \cdot 24 \text { コルチゾール }
$$

参加施設数 66,5 種類の RIA キット (39 施 設), 4 種類の CLIA キット ( 8 施設), 5 種類 の EIA キット (11 施設), 1 種類の FPIA キッ ト (8 施設) が使用された。キット内 CV\%は は 
おおむね 10\% 以下で安定している。しかし， キット間 CV\% は，低值検体で $18.3 \%$ と近年 になく大きい結果となっている。

\section{$3 \cdot 4 \cdot 25$ DHEA-S}

参加施設数 12,2 種類の RIA キットの報告 があった。本年度は non-RI の報告はなかっ た。キット内 CV\% は 10\% 以下で良好である が，キット間 CV\% は $20.9 ， 37.4 ， 14.3 \%$ で あった。

\section{$3 \cdot 4 \cdot 26$ レニン}

参加施設数 18,1 種類の IRMA キットが使 用された。前回までの成績と同様にキット内 CV\% は 10\% 以下であった。

\section{$3 \cdot 4 \cdot 27 \quad \mathrm{IgE}$}

参加施設数 86,2 種類の RIA キット (10 施 設)， 5 種類の IRMA キット (24 施設)， 4 種類 の CLIA キット (17 施設)， 6 種類の EIA キッ 卜 (26 施設)， 4 種類の LPIA キット ( 4 施設), 1 種類の NIA キット ( 2 施設), 1 種類の LAT キット ( 1 施設), 1 種類の PAMIA キット（2 施設）が使用された。多様なキットが使用され たが，キット内 $\mathrm{CV} \%$ は 5.6-7.4\%，キット 間 CV\% 8.4-9.6\% と良好であった。これ らの值は前年と大差はない。

\section{$3 \cdot 4 \cdot 28$ ジゴキシン}

参加施設数 44, 1 種類の RIA キット（ 2 施 設), 7 種類の EIA キット (22 施設)， 1 種類の FPIA キット ( 6 施設), 2 種類の CLIA キット (13 施設), 1 種類の LPIA キット ( 1 施設) が 使用された。キット内 CV\%は低值検体で 10\%を超えたキットああったが，全体では 10\% 以下であった。キット間 CV\% はそれぞ れ $14.8,7.3 ， 8.1 \%$ であった。

\section{$3 \cdot 4 ; 29 \quad \alpha$-フェトプロテイン}

参加施設数 112,2 種類の RIA キット（8 施 設), 4 種類の IRMA キット (37 施設)， 3 種類 の CLIA キット (20 施設), 8 種類の EIA キッ 卜 $(29$ 施設), 3 種類の LPIA キット ( 6 施設), 1 種類の ELISA キット ( 2 施設), 1 種類の PAMIA キット (10 施設) が使用された。キッ
ト内 CV\% は $6.5-8.6 \%$ キット間 CV\% は 9.0 - 9.6\% であり, 前回までの成績と大差は なかった。リアグノスト cAFP の測定值が他 のキットに比べて 3 検体とも低值傾向を示し た。

\section{$3 \cdot 4 \cdot 30 \quad \mathrm{CEA}$}

参加施設数 111,1 種類の RIA キット（ 2 施 設)， 3 種類の IRMA キット (46 施設)，4 種類 の CLIA キット (21 施設), 9 種類の EIA キッ ト (28 施設)，1 種類の LPIA キット ( 4 施設), 1 種類の ELISA キット ( 1 施設), 1 種類の PAMIA キット（9施設）が使用された。キッ ト内 CV\% は $10.6 ， 9.1 \%$ と一見良さそうであ るが，それぞれのキットごとに調べると測定值 の差は大きく，キット間 $\mathrm{CV} \%$ は 73.5, $86.2 \%$ という結果であった。例年 $50 \%$ 台では あるが，本年度は特に大きいようである。ま

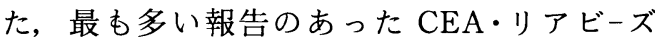
キットの測定值が他のキットに比べて特に低 く, 例年の測定值の傾向とも異なるので, 注意 が必要である。

\section{$3 \cdot 4 \cdot 31$ TPA}

参加施設数 40,2 種類の IRMA キット（39 施設)，1 種類の ELISA キット（1 施設）が使 用された。1 検体のみの検討である。昨年まで はプロリフィゲン TPA-M “第一”のキットが 他のキットの測定値に比べて約 3 倍の高值を示 していたが，本年度は約 3 分の 2 の結果となっ ている。理由は不明である。キット間 CV\% は $38.0 \%$ であった。

\section{$3 \cdot 4 \cdot 32$ CA 125}

参加施設数 91,3 種類の IRMA キット（49 施設)， 3 種類の CLIA キット (15 施設)， 7 種 類の EIA キット (25 施設), 1 種類の PAMIA キット（2 施設）が使用された。2 検体におけ るキット内 $\mathrm{CV} \%$ は $6 \%$ 前後で例年と変わらな かったが，キット間 CV\% は $20 \%$ 前後と昨年 よりあ大きくなっている。

$3 \cdot 4 \cdot 33$ CA $19-9$

参加施設数 104,3 種類の IRMA キット（50 
施設)， 4 種類の CLIA キット (24 施設)， 8 種 類の EIA キット (24 施設), 1 種類の LPIA キット ( 2 施設)， 1 種類の PAMIA キット（ 4 施設）が使用された。2 検体のキット内 CV\% は $10 \%$ 前後で例年通りであったが，キット間 CV\% はやや改善されている。特に RIA 系で は昨年度 $22.6,30.0 \%$ のところ $16.4,18.8 \%$ となった。しかし, LPIA·CA 19-9 テストの低 值検体での高值が目立っている。

\section{$3 \cdot 4 \cdot 34 \quad$ CA $15-3$}

参加施設数 54,3 種類の IRMA キット（34 施設)， 2 種類の CLIA キット ( 8 施設)， 5 種 類の EIA キット（12 施設）が使用された。 キット内 $\mathrm{CV} \%$ は $10 \%$ 前後と例年と大差はな かったが，キット間 CV\%は $6.7,4.1 \%$ と改 善された。

\section{$3 \cdot 4 \cdot 35 \mathrm{PAP}$}

参加施設数 38,2 種類の RIA キット（14 施 設)， 2 種類の IRMA キット ( 9 施設)， 1 種類 の CLIA キット ( 2 施設), 2 種類の EIA キッ ト ( 8 施設), 1 種類の LPIA キット ( 2 施設), 1 種類の FIA キット ( 2 施設), 1 種類の ELISA（ 1 施設）が使用された。キット間 CV $\%$ は経年毎に大きくなっており，本年度はそ れぞれ，28.2，30.4\% となってしまった。 ボールエルザ PAP キットの高值と， DPC・イ ムライズ PAP の低值が目立っている。

\section{$3 \cdot 4 \cdot 36$ PA (PSA)}

参加施設数 81,1 種類の RIA キット ( 2 施 設)， 2 種類の IRMA キット (19 施設)， 6 種類 の CLIA キット (21 施設), 9 種類の EIA キッ 卜 (31 施設)，1 種類の LPIA キット ( 1 施設), 1 種類の PAMIA キット ( 2 施設), 1 種類の FIA キット ( 3 施設), 2 種類の ELISA キット （2 施設）が使用された。RI 系でのキット間 CV\% は 5.8，10.6\% と良好であるが，non-RI 系ではともに $40 \%$ 以上で測定值も 4 倍以上の 開きがあり問題である。

$3 \cdot 4 \cdot 37 \beta_{2}-$ マイクログロブリン

参加施設数 86,3 種類の RIA キット $(38$ 施
設)， 2 種類の CLIA キット ( 6 施設)， 6 種類 の EIA キット (12 施設)， 4 種類の LPIA キッ 卜 $(22$ 施設 $), 1$ 種類の PAMIA キット ( 2 施 設)， 3 種類の LAT キット ( 6 施設) が使用さ れた。キット内 CV\%，キット間 CV\%も $10 \%$ 以下と良好であった。これらは例年と変わらな い值であった。

$3 \cdot 4 \cdot 38$ フェリチン

参加施設数 92,1 種類の RIA キット（ 3 施 設), 4 種類の IRMA キット (24 施設)， 5 種類 の CLIA キット (28 施設), 6 種類の EIA キッ 卜 (14 施設), 3 種類の LPIA キット（12 施 設)， 1 種類の PAMIA キット ( 6 施設)， 1 種 類の ECLIA キット ( 2 施設), 2 種類の LAT キット ( 2 施設), 1 種類の ELISA キット ( 1 施設）が使用された。昨年度 $6 \%$ 台であった キット内 CV\% は本年度は, $14.5,7.7 \%$ と なった。キット間 CV\%は 15.4，17.7\% と昨 年度と大差はなかった。

\section{$3 \cdot 4 \cdot 39$ NSE}

参加施設数 41,3 種類の RIA キット $(27$ 施 設), 3 種類の IRMA キット (11 施設), 3 種類 の EIA キット（ 3 施設）が使用された。本年度 より新たに採用された項目である。キット内 $\mathrm{CV} \%$ ，キット間 CV\% とも 10\% 前後の結果で あった。

\section{$3 \cdot 5$ キットごとの変動係数の変動}

表 11 に示すように，同一キットによる測定 値の変動（注：検体自体は毎年異なる）を見る と, 大部分のキットでは CV\% が 10\% 以下の 值を示した。低濃度検体では一部で $10 \%$ 以上 を示すあのああるが，これは感度の問題と思わ れる。Abビーズインシュリン“栄研”, CEA・ リアビーズの CV\% が今回大きいのは残念であ る。理由は不明である。

\section{4. 考察}

$4 \cdot 1$ 参加施設と測定キットの種類 前年度までと同様に第 20 回のサーベィでは 
全国の関連 施設に検体を送付し，その結果を 解析した。今回のサーベイには 143 施設が参加 し, 参加数は, 18 施設減少し, 参加率む $2.4 \%$ 減少して $50.2 \%$ であった。参加施設で測定さ れた項目は延べ 2471 項目で，そのうち non isotopic (non-RI) 法による測定は 1208 項目 (48.9\%) で昨年度の $44.5 \%$ よりさらに増加し た。non-RI 法の占める割合は年々増加し, 今 後もこの傾向は続くと思われる。また， non-RI 法による测定も EIA, ELISA, LIA, CLIA, FIA, EPIA, PAMIA, ECLIA など多様に なってきている。

\section{$4 \cdot 2$ 検体の測定に関する基礎的検討}

昨年と同様, 今回サーベイに使用した検体 （A-1, A-2，A-3 および B-1，B-2）はすべて凍結乾 燥品を用いた。これら検体の蛋白組成はいずれ あ血清と同等であった。サーベイに際して起こ りうる凍結融解の影響も表 5 に示した項目につ いてはないと考える。14 種類のキットを用い た同時再現性試験（表 3 ），検体試料の日差再 現性試験（表 4 ）の結果も満足すべき結果で あった。検体の融解後の保存条件についての検 討では $4{ }^{\circ} \mathrm{C}$ および室温での保存でカルシトニ ン, C-ペプチド，ガストリン，PA（PSA）で 測定值の低下が認められた（表 6 ）。室温保存 の場合には，インスリンも測定值の低下が見ら れた。なお，グルカゴンに関しては室温保存で 経時的な測定值の上昇が認められた。測定値の 増加の理由は明らかではないが非特異的なもの と考える。いずれにせよ，保存条件の差は今回 までのサーベイの結果に影響を与えるものでは ないと考えられる。

\section{$4 \cdot 3$ 各測定キットによる測定値}

10 施設以上で使用されだットごとに計算 した変動係数は大部分で 10\% 以下であった (表 11)。昨年までの結果では例年大きな変化 は見られなかったのであるが，本年度は $\mathrm{Ab}$ ビーズインシュリン“栄研’ のばらつきが大き
く，特に低值では $20 \%$ を超えてしまった。 $\mathrm{CEA}$ リアビーズは最も多くの施設が使用して いるキットであるにもかかわらず，測定值は著 しく低値で, CV\%あ大きかった。理由は不明で あるが測定者の技術等の問題ではないであろ う。

$4 \cdot 4$ キット内変動, キット間変動

RI 法と non-RI 法の両者での報告があった 項目につきキット内 $\mathrm{CV} \%$ を比較した結果では 中濃度，高濃度検体でキット内 $\mathrm{CV} \%$ が $10 \%$ 以上ある項目が RI 法では 7 項目, non-RI 法 では 5 項目であり, 大部分で差は見られなかっ た。昨年度指摘された FSH WHO 2nd IRP 78/ 549 に準拠しているキットの測定内 CV\% は RI 法で 4.0 - 5.2\%，non-RI 法で 6.4-8.6\% と改善された。キット間 CV\% あ大部分の項目 で両者の差は認められなかったが，C-ペプチ ドで RI 法での CV\% が 22.5 - 28.9\% と non-RI に比べて高く, PSA では逆に non-RI 法で 44.2-45.5\% と大きかった。

キット内 $\mathrm{CV} \%$ が 3 検体のうち 2 検体以上, あるいは 2 検体のうち 1 検体以上で $10 \%$ を超 えるものは，RI 法で 17\%（7/41)，すべての検 体で CV\% が 10\% を超えるものはカルシトニ ンだけで，昨年より改善されている。また，す べての検体で 10\% 以下の項目は 51\% (21/41) で昨年と同じであった。CV\% が 20\%を超え た項目は $17 \alpha$-OHP であった。Non-RI 法でも 同様にキット内 CV\% が 10\% を超えた項目は $6 \%(2 / 33)$ ，すべての検体で 10\% を超えた項 目はPA（PSA）のみであり，すべての検体で 10\% 以下の項目は 70\%（23/33）といずれも昨 年度より改善されていた。

一方，キット間 CV\% についてみると，すべ ての検体が 20\% を超えた項目は RI 法で34\% (11/32)，non-RI 法で 23\%（7/30）であった。 3 検体のうち 2 検体以上, 2 検体のうち 1 検体 以上で CV\% が $20 \%$ を超える項目は RI 法で 44\%（14/32），non-RI 法では 30\%（9/30）であ 
り，昨年度のそれぞれ $58.6 \% ， 43 \%$ と比較す ると改善された。RI 法と non-RI 法をまとめ てみた場合には（表 8-3），キット内 CV\% が 3 検体のうち 2 検体以上, 2 検体のうち 1 検体以 上で CV\% が 10\% を超える項目は 33\%（15/ 45）であった。すべての検体で $10 \%$ 以下の值 を示したのは $56 \%(25 / 45)$ であった。キット 間 CV\% では 3 検体のうち 2 検体以上， 2 検体 のうち 1 検体以上で CV\% が $20 \%$ を超える項 目は 43.6\% (17/39)，すべての検体で 30\% を 超える項目が 10\%（4/39）存在した。

$\mathrm{RI}$ 法のキット内 CV\% の年次変化 (表 9-1) を見ると，多少の変動はあるあのの $\mathrm{CV} \%$ は $10 \%$ 以下，あるいは $10 \%$ に近い值を示してい る。昨年度のサーベィですべての検体で 10\% 以上の CV\% を出していたのはカルシトニン, プロラクチン，グルカゴンであったが，本年度 はカルシトニン, $17 \alpha$-OHP, CEA, フェリチン であった。CEA の場合は，最も使用者数の多 いキットでの測定值が不安定でばらつきも大き いため, 理由の解明が是非とも必要である。 Non-RI 法ではキット内 CV\% は多くは 10\% 以下であるが, 昨年度のサーベイですべての検 体で $10 \%$ 以上の CV\%を出していたのはプロ ゲステロン，LH の 2 項目であったが，本年度 はPA（PSA）のみとなった。RI 法と non-RI 法を合わせたキット内 $\mathrm{CV} \%$ の年次変化は, 昨 年度のサーベイですべての検体で $10 \%$ 以上の $\mathrm{CV} \%$ を示していたのはカルシトニン, プロラ クチン，グルカゴンであったが，本年度はカ ルシトニン, $17 \alpha$-OHP, PA (PSA) であった。 $17 \alpha$-OHP は検体試料の問題も否定できず, PA（PSA）も昨年度と大幅に変わったわけで はないので, 全体としては, 徐々に改善される 傾向にあるといえる。

キット間 CV\% の経年変化 (表 9-2) あ同様 に例年と比較して大きな変化はなく, RI 法と non-RI 法を合わせた CV\% は高い項目は高く， 低い項目は低く推移していた。すべての検体の CV\% が 10\% 以下，あるいは 10\% 台にとど
まっているのは $47 \%$ (15/32)，3 検体のうち 2 検体以上， 2 検体のうち 1 検体以上で $\mathrm{CV} \%$ が $30 \%$ を超える項目は $18.8 \%$ （6/32）であった。 最近 5 年間の成績は古い順に $21.2 \%(7 / 33)$, $26.5 \%(9 / 34), 27.3 \%(9 / 33) ， 20.6 \%$ (7/ $34), 18.8 \%$ (6/32) で本年度が一番低かった。 しかし，まだまだ喜べる状態ではなく，全体の 2 割もの項目で測定方法を確認しなければ測定 値を比較できないという状態である。

\section{5. 結 論}

以上，今回のサーベイの結果は従来までの成 績と大きな差はなく，昨年よりやや改善された 傾向は見られるが，多くの項目で臨床的にはま だ満足すべき状態からは遠い現状であった。こ れも例年言われていて，いっこうに改善される きざしがないのであるが，キット間差の解消に はメーカー全体としての対応が不可欠であり， 測定値の混乱の原因の一つである標準品の統一 化あ急務である。一方, 検体試料のマトリック ス効果による問題も無視できない。今年度, CEA が例年とは異なる動きを見せ，原因は キットにあるのか，検体にあるのか不明である が，何とか解明したい。また， 3 検体の濃度が 低・中・高となっていない項目ああり，設定濃 度を改善する必要がある。本サーベイは各測定 施設における自己の評価にあ有用である。この 結果が各施設の測定の信頼性を高める一助に なれば幸いである。多くの方々の時間をいただ いて得た資料であるので，できうる限り公開 し,さらに精度のよいキット開発に役立つこと を願っている。

最後に今回のサーベイにご協力いただいた各 位に感謝いたします。 
表 1 参加施設数および項目別参加数

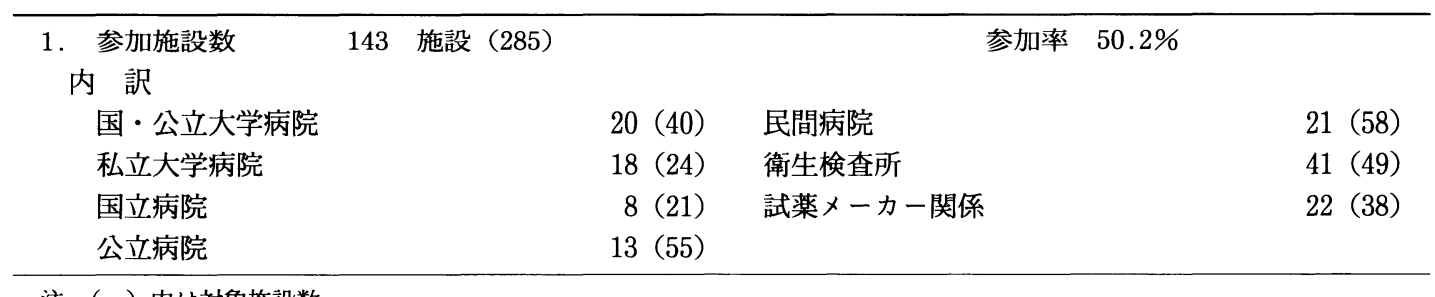

注（）内は対象施設数。

\begin{tabular}{|c|c|c|c|}
\hline 2. 項目別参加数 & & & \\
\hline 内 訳 & & & \\
\hline$\diamond$ 下垂体機能 & & $\diamond$ 副腎機能 & \\
\hline GH & $41(8)$ & $17 \alpha$-ヒドロキシプロゲステロン & 6 \\
\hline ソマトメジンC & 18 & アルドステロン & 51 \\
\hline FSH & $35(54)$ & コルチゾール & $39(27)$ \\
\hline $\mathrm{LH}$ & $35(54)$ & DHEA-S & 12 \\
\hline プロラクチン & $33(50)$ & $\diamond$ 腎・血圧調節機能 & \\
\hline $\mathrm{TSH}$ & $48(76)$ & レニン定量 & 18 \\
\hline$\diamond$ 甲状腺機能 & & ○免疫グロブリン & \\
\hline $\mathrm{T}_{3}$ & $39(61)$ & $\operatorname{IgE}$ & $34(52)$ \\
\hline Free $T_{3}$ & $42(70)$ & ○薬物 & \\
\hline $\mathrm{T}_{4}$ & $37(62)$ & ジゴキシン & $2(42)$ \\
\hline Free $T_{4}$ & $47(74)$ & ○腫痬マーカー & \\
\hline TBG & $24(2)$ & 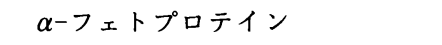 & $45(67)$ \\
\hline$\diamond$ 副甲状腺機能 & & CEA & $48(63)$ \\
\hline カルシトニン & 23 & TPA & $39(1)$ \\
\hline$\diamond$ 膵・消化管機能 & & CA 125 & $49(42)$ \\
\hline インスリン & $71(36)$ & CA $19-9$ & $50(54)$ \\
\hline Cーペプチド & $58(10)$ & CA $15-3$ & $34(20)$ \\
\hline グルカゴン & 13 & PAP & $23(15)$ \\
\hline ガストリン & 24 & PA (PSA) & $21(60)$ \\
\hline$\diamond$ 性腺・胎盤機能 & & $\beta_{2}-$ マイクログロブリン & $38(48)$ \\
\hline ・テストステロン & $23(14)$ & フェリチン & $27(65)$ \\
\hline Free テストステロン & 9 & NSE & $38(3)$ \\
\hline エストラジオール & $31(33)$ & & \\
\hline プロゲステロン & $29(28)$ & & \\
\hline$\beta \mathrm{HCG}$ & $9(17)$ & & \\
\hline
\end{tabular}

注（）内は non-isotopic 法による測定数。 
表 2 検体試料中の蛋白組成

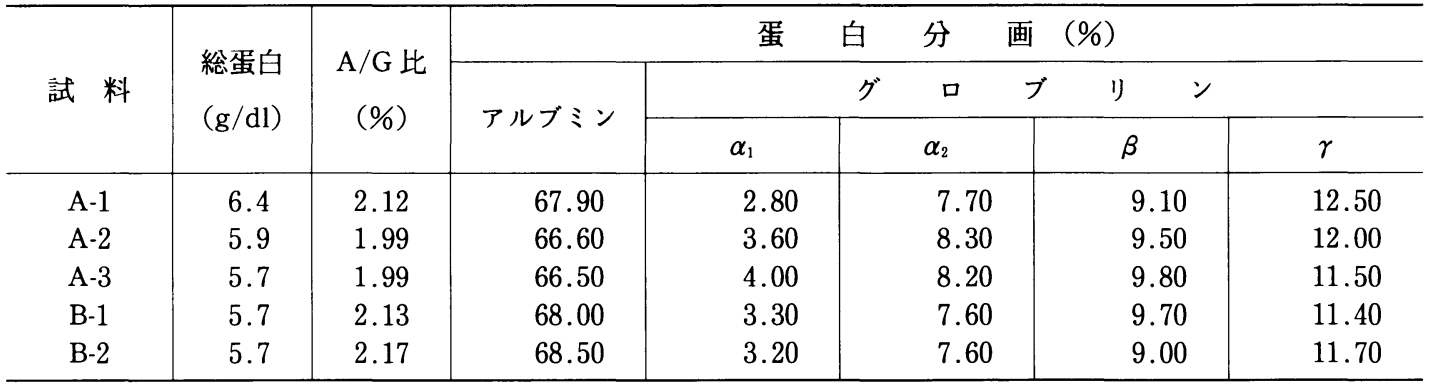

表 3 検体試料の同時再現性試験結果

\begin{tabular}{|c|c|c|c|c|c|c|c|c|c|c|c|c|c|}
\hline \multirow{2}{*}{ 項 } & \multirow{2}{*}{ 単 位 } & \multicolumn{4}{|c|}{ 検体試料 A-1 } & \multicolumn{4}{|c|}{ 検体試料 A-2 } & \multicolumn{4}{|c|}{ 検体試料 A-3 } \\
\hline & & $N$ & $M$ & $\mathrm{SD}$ & $\mathrm{CV}$ & $N$ & $M$ & SD & $\mathrm{CV}$ & $N$ & $M$ & $\mathrm{SD}$ & $\mathrm{CV}$ \\
\hline ソマトメジンC & $\mathrm{ng} / \mathrm{ml}$ & 10 & 68.2 & 2.57 & 3.77 & 10 & 87.8 & 61 & .25 & 10 & 69.4 & 2.12 & 3.05 \\
\hline $\mathrm{FSH}$ & $\mathrm{mIU} / \mathrm{ml}$ & 10 & 10.6 & & 4.8 & 10 & 20.3 & .39 & 9 & 10 & 48.8 & 2.13 & 4.4 \\
\hline LH & $\mathrm{mIU} / \mathrm{ml}$ & 10 & 2.7 & 0.17 & 6.3 & 10 & 18.6 & 0.58 & 1 & 10 & 38.1 & 0.86 & 2.3 \\
\hline TSH & $\mu \mathrm{U} / \mathrm{ml}$ & 10 & 0.32 & 0.014 & 4.4 & 10 & 8.41 & 0.179 & 2.1 & 10 & 22.2 & 0.35 & 1.6 \\
\hline カルシトニン & $\mathrm{pg} / \mathrm{ml}$ & 10 & 72.4 & 3.66 & 5.06 & 10 & 428 & 16.2 & 3.79 & 10 & 932 & 29.0 & 3.11 \\
\hline インスリン & $\mu \mathrm{U} / \mathrm{ml}$ & 10 & 16.2 & 0.70 & 4.3 & 10 & 54.1 & 1.01 & 1.9 & 10 & 141.3 & 2.84 & 2.0 \\
\hline C-ペプチド & $\mathrm{ng} / \mathrm{ml}$ & 10 & 2.8 & 0.13 & 4.6 & 10 & 7.6 & 0.33 & 4.3 & 10 & 16.0 & 0.78 & 4.9 \\
\hline グルカゴン & $\mathrm{pg} / \mathrm{ml}$ & 10 & 125 & 7.07 & 5.66 & 10 & 227 & 9.49 & 4.18 & 10 & 247 & 8.23 & 3.33 \\
\hline ガストリン & $\mathrm{pg} / \mathrm{ml}$ & 10 & 59.1 & 4.949 & 8.37 & 10 & 278 & 9.80 & 3.52 & 10 & 766 & 33.53 & 4.38 \\
\hline Freeテストステロン & $\mathrm{pg} / \mathrm{ml}$ & 10 & 1.04 & 0.092 & 8.81 & 10 & 10.4 & 0.431 & 4.15 & 10 & 35.66 & 1.079 & 3.03 \\
\hline$\beta \mathrm{HCG}$ & $\mathrm{ng} / \mathrm{ml}$ & 10 & $<0.1$ & - & - & 10 & 0.1 & 0.0 & 0.0 & 10 & 0.96 & 0.05 & 5.2 \\
\hline DHEA-S & $\mu \mathrm{g} / \mathrm{dl}$ & 10 & 17.4 & 1.39 & 8.0 & 10 & 135.1 & 5.77 & 4.3 & 10 & 520.4 & 21.7 & 4.0 \\
\hline レニン定量 & $\mathrm{pg} / \mathrm{ml}$ & 10 & 23.5 & 1.18 & 5.01 & 10 & 34.1 & 0.99 & 2.92 & 10 & 30.6 & 1.07 & 3.51 \\
\hline PA (PSA) & $\mathrm{ng} / \mathrm{ml}$ & 10 & 5.59 & 0.120 & 2.15 & 10 & 56.9 & 1.45 & 2.55 & & & & \\
\hline
\end{tabular}

注 1 測定は同一時の10重測定によるもので，それぞれの測定値は10重測定の平均值による集計。

注 2 PA (PSA) は，検体試料 B-1 および B-2 で測定した。

注 3 再現性・安定性試験に用いた測定試薬（表 3 - 表 6)。

\begin{tabular}{|c|c|c|}
\hline ソマトメジンC & ; ソマトメジンC・II「カイロン」 & (カイロン) \\
\hline FSH & ; スパック-S FSH キット & （第一 RI 研究所） \\
\hline LH & ; スパック-S LH キット & （第一 RI 研究所） \\
\hline TSH & ; TSH・リアビーズII & (ダイナボット) \\
\hline カルシトニン & ; カルシトニン RIA「ミッビシ」 & （三菱化学） \\
\hline インスリン & ; インスリンリアビーズ II & （ダイナボット） \\
\hline C-ペプチド & ; C-ペプチドリアシオノギ & （塩野義製薬） \\
\hline グルカゴン & ；グルカゴンキット「第一」 & （第一 RI 研究所） \\
\hline ガストリン & ; ガストリン・リアキット II & （ダイナボット） \\
\hline Free テストステロン & ; DPC・フリーテストステロンキット & （日本 DPC） \\
\hline$\beta \mathrm{HCG}$ & ; ボールエルザ・F- $\beta \mathrm{HCG} ・ キ ッ ト$ & (シーアイエスダイアグノスティック) \\
\hline DHEA-S & ; DPC・DHEA-S キット & (日本 DPC) \\
\hline レニン定量 & ; レニン IRMA「第一」 & （第一 RI 研究所） \\
\hline PA (PSA) & ; タンデム PSA & （ヤマサ醬油） \\
\hline
\end{tabular}


表 4 検体試料の日差再現性試験結果

\begin{tabular}{|c|c|c|c|c|c|c|c|c|c|c|c|c|c|}
\hline \multirow{2}{*}{ 項 } & \multirow{2}{*}{ 単 位 } & \multicolumn{4}{|c|}{ 検体試料 A-1 } & \multicolumn{4}{|c|}{ 検体試料 A-2 } & \multicolumn{4}{|c|}{ 検体試料 A-3 } \\
\hline & & $N$ & $M$ & SD & $\mathrm{CV}$ & $N$ & $M$ & SD & $\mathrm{CV}$ & $N$ & $M$ & SD & $\mathrm{CV}$ \\
\hline ソマトメジンC & $\mathrm{ng} / \mathrm{ml}$ & 5 & 67.8 & 3.03 & 4.47 & 5 & 86.4 & 3.44 & 3.98 & 5 & 69.8 & 2.49 & 3.57 \\
\hline FSH & $\mathrm{mIU} / \mathrm{ml}$ & 5 & 10.8 & 0.24 & 2.2 & 5 & 20.3 & 0.53 & 2.6 & 5 & 49.2 & 1.40 & 2.8 \\
\hline LH & $\mathrm{mIU} / \mathrm{ml}$ & 5 & 2.6 & 0.13 & 5.0 & 5 & 18.2 & 0.67 & 3.7 & 5 & 38.3 & 0.43 & 1.1 \\
\hline TSH & $\mu \mathrm{U} / \mathrm{ml}$ & 5 & 0.33 & 0.019 & 5.8 & 5 & 8.58 & 0.124 & 1.4 & 5 & 22.2 & 0.27 & 1.2 \\
\hline カルシトニン & $\mathrm{pg} / \mathrm{ml}$ & 5 & 72.6 & 2.41 & 3.32 & 5 & 436 & 27.0 & 6.19 & 5 & 924 & 28.8 & 3.12 \\
\hline インスリン & $\mu \mathrm{U} / \mathrm{ml}$ & 5 & 16.1 & 0.51 & 3.2 & 5 & 53.9 & 2.08 & 3.9 & 5 & 141.4 & 2.08 & 3.3 \\
\hline Cーペプチド & $\mathrm{ng} / \mathrm{ml}$ & 5 & 2.7 & 0.11 & 4.1 & 5 & 7.5 & 0.26 & 3.5 & 5 & 15.8 & 0.65 & 4.1 \\
\hline グルカゴン & $\mathrm{pg} / \mathrm{ml}$ & & 130 & 12.75 & 9.81 & 5 & 245 & 19.69 & 8.04 & 5 & 260 & 22.08 & 8.49 \\
\hline ガストリン & $\mathrm{pg} / \mathrm{ml}$ & 5 & 61.90 & 6.841 & 11.05 & 5 & 302.0 & 30.33 & 10.04 & 5 & 682.0 & 60.27 & 8.84 \\
\hline Free テストステロン & $\mathrm{pg} / \mathrm{ml}$ & 5 & 0.922 & 0.03 & 3.29 & 5 & 10.31 & 1.617 & 15.69 & 5 & 32.02 & 4.111 & 12.84 \\
\hline$\beta H C G$ & $\mathrm{ng} / \mathrm{ml}$ & 5 & $<0.1$ & - & - & 5 & 0.1 & 0.0 & 0.0 & 5 & 0.94 & 0.05 & 5.3 \\
\hline DHEA-S & $\mu \mathrm{g} / \mathrm{dl}$ & 5 & 18.1 & 1.27 & 7.0 & 5 & 145.5 & 5.09 & 3.5 & 5 & 506.1 & 26.12 & 5.2 \\
\hline レニン定量 & $\mathrm{pg} / \mathrm{ml}$ & 5 & 24.8 & 1.255 & 5.06 & 5 & 37.7 & 2.971 & 7.88 & 5 & 32.5 & 2.264 & 6.97 \\
\hline $\mathrm{PA}(\mathrm{PSA})$ & $\mathrm{ng} / \mathrm{ml}$ & 5 & 5.56 & 0.182 & 3.27 & 5 & 57.6 & 1.147 & 1.98 & & & & \\
\hline
\end{tabular}

注 1 測定は 5 回の異なった日に実施。

注 2 それぞれの測定値は 2 重測定の平均値による集計。

注 3 PA (PSA) は，検体試料 B-1 および B-2 で測定した。

表 5 検体試料の凍結融解の絽返し試験結果

\begin{tabular}{l|c|c|c|c|c|c|c|c|c|c}
\hline \multirow{2}{*}{\multicolumn{1}{c|}{ 項 }} & \multirow{2}{*}{ 単 位 } & \multicolumn{3}{c|}{ 検体試料 $\mathrm{A}-1$} & \multicolumn{3}{c|}{ 検体試料 $\mathrm{A}-2$} & \multicolumn{3}{|c}{ 検体試料 A-3 } \\
\cline { 3 - 11 } & & 1 回 & 3 回 & 5 回 & 1 回 & 3 回 & 5 回 & 1 回 & 3 回 & 5 回 \\
\hline ソマトメジンC & $\mathrm{ng} / \mathrm{ml}$ & 68 & 65 & 64 & 86 & 85 & 84 & 68 & 63 & 64 \\
$\mathrm{FSH}$ & $\mathrm{mIU} / \mathrm{ml}$ & 10.6 & 10.4 & 10.3 & 20.3 & 19.9 & 18.3 & 48.8 & 49.8 & 44.4 \\
$\mathrm{LH}$ & $\mathrm{mIU} / \mathrm{ml}$ & 2.7 & 2.7 & 2.9 & 18.6 & 18.1 & 18.5 & 38.1 & 37.7 & 39.4 \\
$\mathrm{TSH}$ & $\mu \mathrm{U} / \mathrm{ml}$ & 0.32 & 0.29 & 0.35 & 8.41 & 8.55 & 8.59 & 22.2 & 21.8 & 21.9 \\
カルシトニン & $\mathrm{pg} / \mathrm{ml}$ & 71 & 68 & 66 & 420 & 420 & 400 & 970 & 900 & 900 \\
インスリン & $\mu \mathrm{U} / \mathrm{ml}$ & 15.7 & 15.8 & 15.8 & 54.0 & 52.0 & 52.2 & 139.5 & 136.1 & 137.2 \\
C-ペプチド & $\mathrm{ng} / \mathrm{ml}$ & 2.7 & 2.5 & 2.5 & 7.6 & 7.4 & 7.3 & 16.0 & 15.8 & 15.8 \\
グルカゴン & $\mathrm{pg} / \mathrm{ml}$ & 145 & 140 & 140 & 280 & 270 & 265 & 290 & 285 & 295 \\
ガストiン & $\mathrm{pg} / \mathrm{ml}$ & 43.5 & 40.5 & 40.0 & 225 & 210 & 205 & 565 & 525 & 480 \\
Free テストステロン & $\mathrm{pg} / \mathrm{ml}$ & 0.8 & 0.9 & 0.9 & 8.3 & 8.3 & 8.1 & 29.9 & 28.5 & 29.6 \\
$\beta H C G$ & $\mathrm{ng} / \mathrm{ml}$ & $<0.1$ & $<0.1$ & $<0.1$ & 0.1 & 0.1 & 0.1 & 1.0 & 1.0 & 0.9 \\
DHEA-S & $\mu \mathrm{g} / \mathrm{dl}$ & 17.4 & 17.6 & 17.4 & 135.1 & 135.7 & 134.3 & 520.4 & 558.9 & 528.7 \\
レニン定量 & $\mathrm{pg} / \mathrm{ml}$ & 23.0 & 24.5 & 24.0 & 36.0 & 37.0 & 37.5 & 33.0 & 32.5 & 33.0 \\
\hline PA(PSA) & $\mathrm{ng} / \mathrm{ml}$ & 5.5 & 5.5 & 5.5 & 58 & 57 & 57 & & & \\
\hline
\end{tabular}

注 1 それぞれの娜定値は 2 重測定の平均値による集計。

注 2 PA (PSA) は, 検体試料 B-1 および B-2 で測定した。 


\begin{tabular}{|c|c|c|c|c|c|c|c|c|c|c|}
\hline & 彎 & $\notin$ i̊ & ت & $\left|\begin{array}{ccc}0 & \infty & \infty \\
\infty & \infty & \infty \\
\infty & \infty & \infty\end{array}\right|$ & 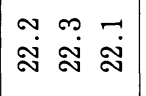 & 응 \&్రి & 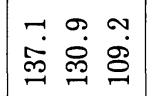 & $\begin{array}{lll}0 & 0 & \infty \\
\dot{J} & \ddots & 0\end{array}$ & 点 绍 误 & ஜ ஜ ஓ ণ \\
\hline & 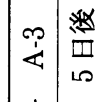 & $\notin \vec{\sigma}$ & $\mid \begin{array}{lll}0 & 0 & 0 \\
\infty & \dot{q} & \infty \\
\dot{q} & \infty & \infty\end{array}$ & 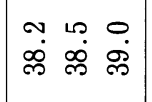 & 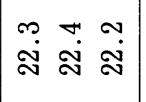 & 吕 \& & 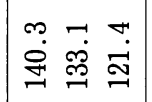 & 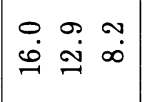 & శ్ఞ శ్లి శ్లి & ิㅗㅇํำ ำ \\
\hline & 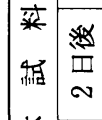 & 15 & 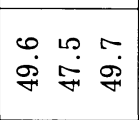 & 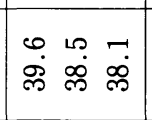 & 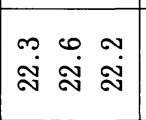 & 냉 옴 웜 & 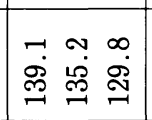 & 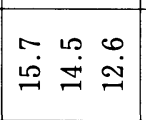 & 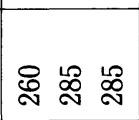 & م \\
\hline & 䇾 & I. & $\mid \begin{array}{lll}0 & \infty & 1 \\
\dot{0} & \dot{q} & \infty \\
10 & \infty\end{array}$ & 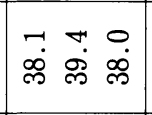 & 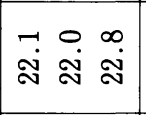 & \& & 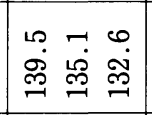 & $\left|\begin{array}{ccc}0 & 0 & \infty \\
\dot{0} & \dot{J} & \oplus \\
\end{array}\right|$ & 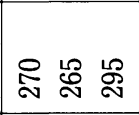 & ๕ి గ్రి ర్ণ \\
\hline & $\begin{array}{l}\text { 监 } \\
0\end{array}$ & \begin{tabular}{l|ll}
$\mid$ & $\mid$ & $\infty$
\end{tabular} \mid & 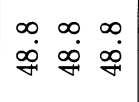 & 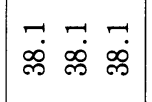 & 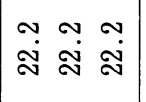 & | 옹 | & 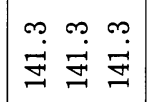 & $\begin{array}{lll}0 & 0 & 0 \\
\dot{0} & \oplus & 0 \\
\ddots & \ddots & \ddots\end{array}$ & 옷尺ㅗㅇํㅗ & 员员 员 \\
\hline & 亶 & $\vec{\infty} \cong \vec{\imath}$ & 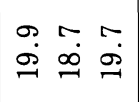 & $\left|\begin{array}{lll}\infty & \infty & 0 \\
\infty & 0 & 0 \\
\hdashline & 0 & 0\end{array}\right|$ & $\left|\begin{array}{lll}\infty & 0 & 0 \\
\infty & 10 & 0 \\
\infty & \infty & \infty\end{array}\right|$ & 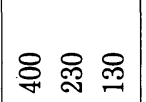 & 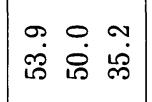 & 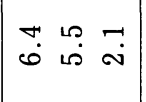 & 占 유 \& & 욤 $\stackrel{\circ}{\dot{9}} \stackrel{0}{9}$ \\
\hline & 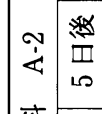 & 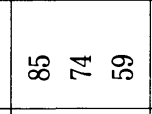 & 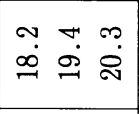 & 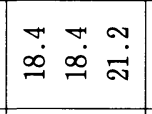 & 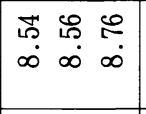 & 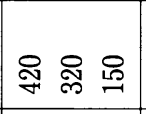 & 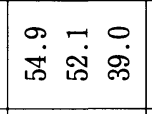 & $\left|\begin{array}{lll}\sigma & \sim & 0 \\
0 & 10 & 0\end{array}\right|$ & 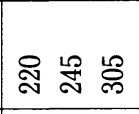 & ๙ิ \\
\hline & 标 & $\infty \infty$ & 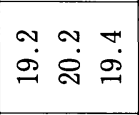 & $\left.\mid \begin{array}{lll}\infty & \infty & \infty \\
\infty & \infty & \infty \\
-1 & \infty & 9\end{array}\right]$ & 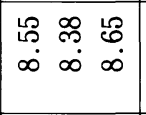 & 육 & 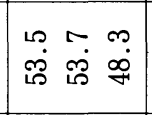 & $\mid$\begin{tabular}{lll}
0 & 0 & \multirow{2}{*}{} \\
$\sim$ & $\stackrel{0}{*}$ & 0
\end{tabular} & 웡 \&્ণ & L \\
\hline & 渠 & $\infty \propto \infty$ & 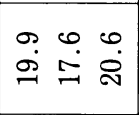 & $\begin{array}{ccc}\sim & - & 0 \\
\infty & \infty & \stackrel{\sigma}{-}\end{array}$ & $\begin{array}{ccc}P & 8 & \infty \\
\infty & \infty & \infty \\
\infty & \infty & \infty\end{array} \mid$ & 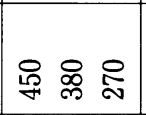 & ถேं & 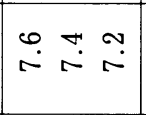 & 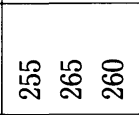 & L \\
\hline & 愁 & $|\infty|$ & m & $\left|\begin{array}{lll}0 & 0 & 0 \\
\infty & \infty & 0 \\
- & 0 & 0\end{array}\right|$ & $\mid \begin{array}{ccc}\exists & \exists & F \\
\infty & \infty & \infty\end{array}$ & $|\underset{\&}{\&}|$ & 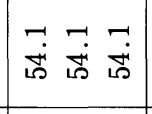 & $\mid \begin{array}{lll}0 & 0 & 0 \\
\sim & \stackrel{\sim}{r} & \sim\end{array}$ & 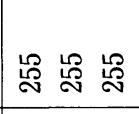 & 品 㒸 \\
\hline & 塄 & 8 & 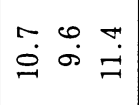 & $\left|\begin{array}{lll}\infty & \overrightarrow{0} & 0 \\
\dot{\sim} & \stackrel{\sim}{\sim} & \stackrel{\sim}{\sim}\end{array}\right|$ & 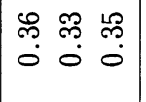 & ఇ & 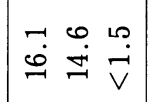 & 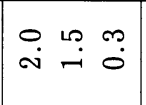 & 胫 占 号 & 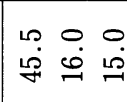 \\
\hline & 安 & 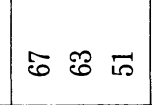 & $\stackrel{0}{\bullet} \because$ & 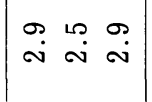 & $\left|\begin{array}{ccc}\dddot{m} & \dddot{m} & \tilde{m} \\
0 & 0 & 0\end{array}\right|$ & 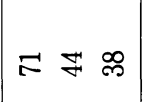 & ש مِ & $\left|\begin{array}{lll}m & 0 & 0 \\
\sim & -i & 0\end{array}\right|$ & 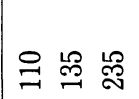 & 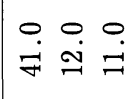 \\
\hline & 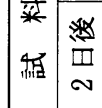 & 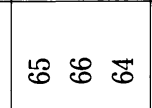 & $\begin{array}{lll}\sim & 0 & \ddots \\
0 & \beth & \beth\end{array}$ & $\mid \begin{array}{lll}\ddot{a} & \vec{\sim} & \infty \\
\dot{\sim} & \stackrel{i}{v}\end{array}$ & $\left|\begin{array}{ccc}\mathscr{m} & \text { mె } & \text { లె } \\
0 & 0 & 0\end{array}\right|$ & 농 & 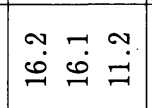 & 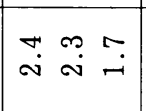 & 呑 号 & 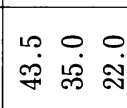 \\
\hline & 然 & 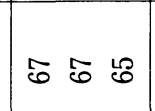 & $\ddot{0} \tilde{0}$ & 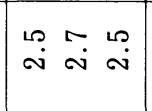 & $\begin{array}{ccc}\tilde{m} & \bar{m} & \text { mे } \\
0 & 0 & 0\end{array}$ & 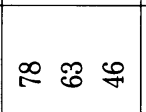 & 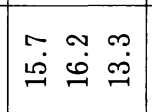 & 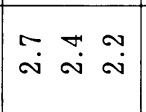 & 录 喿 孚 & 茴 \\
\hline & 筒 & $|\infty|$ & $\begin{array}{lll}0 & 0 & 0 \\
\dot{0} & \dot{0} & \dot{0}\end{array}$ & $\vec{\sim} \vec{\sim} \vec{o}$ & $\left|\begin{array}{ccc}\tilde{m} & \tilde{ఢ} & \tilde{ఢ} \\
0 & 0 & 0\end{array}\right|$ & $|\stackrel{\infty}{\infty}|$ & 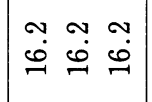 & $\left|\begin{array}{lll}\infty & \infty & \infty \\
\sim & \sim & \sim \\
& & \end{array}\right|$ & 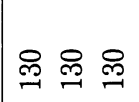 & 항 \\
\hline & 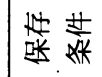 & 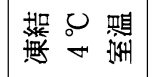 & 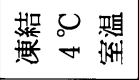 & 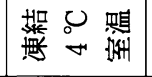 & 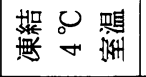 & 拱 品 & 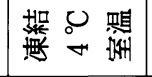 & 墱 。 & 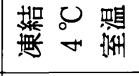 & 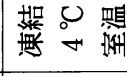 \\
\hline & 四团 & 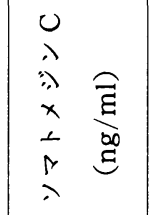 & 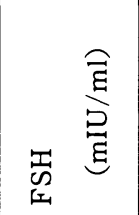 & 莺 & 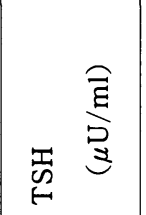 & 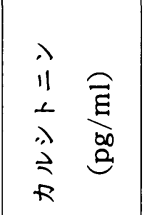 & 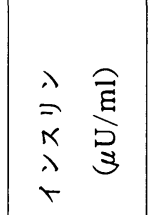 & 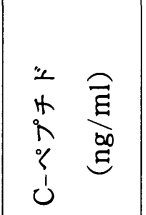 & $\begin{array}{ll}\hat{r} & \widehat{\vec{g}} \\
\hat{R} & 0 \\
\stackrel{0}{2} & \end{array}$ & 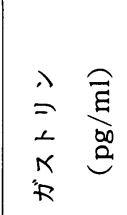 \\
\hline
\end{tabular}




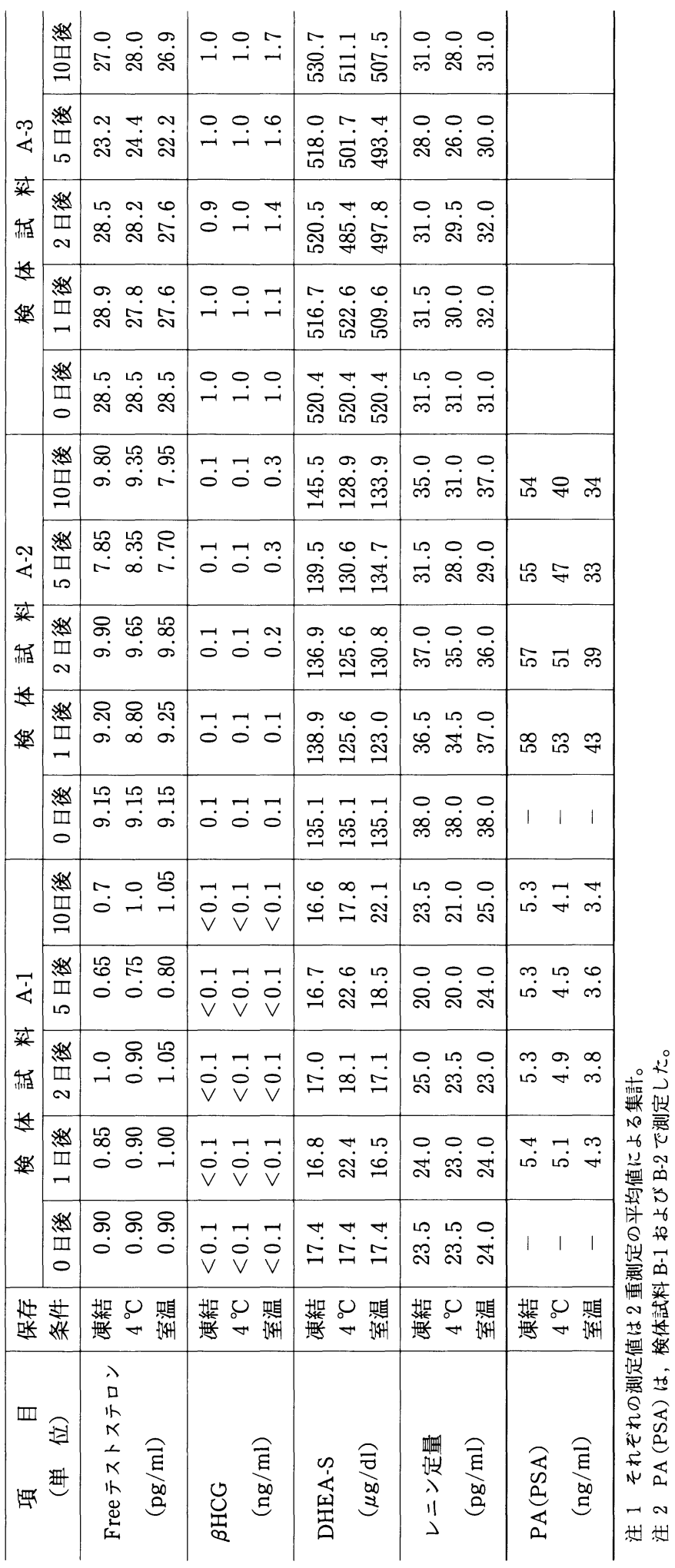




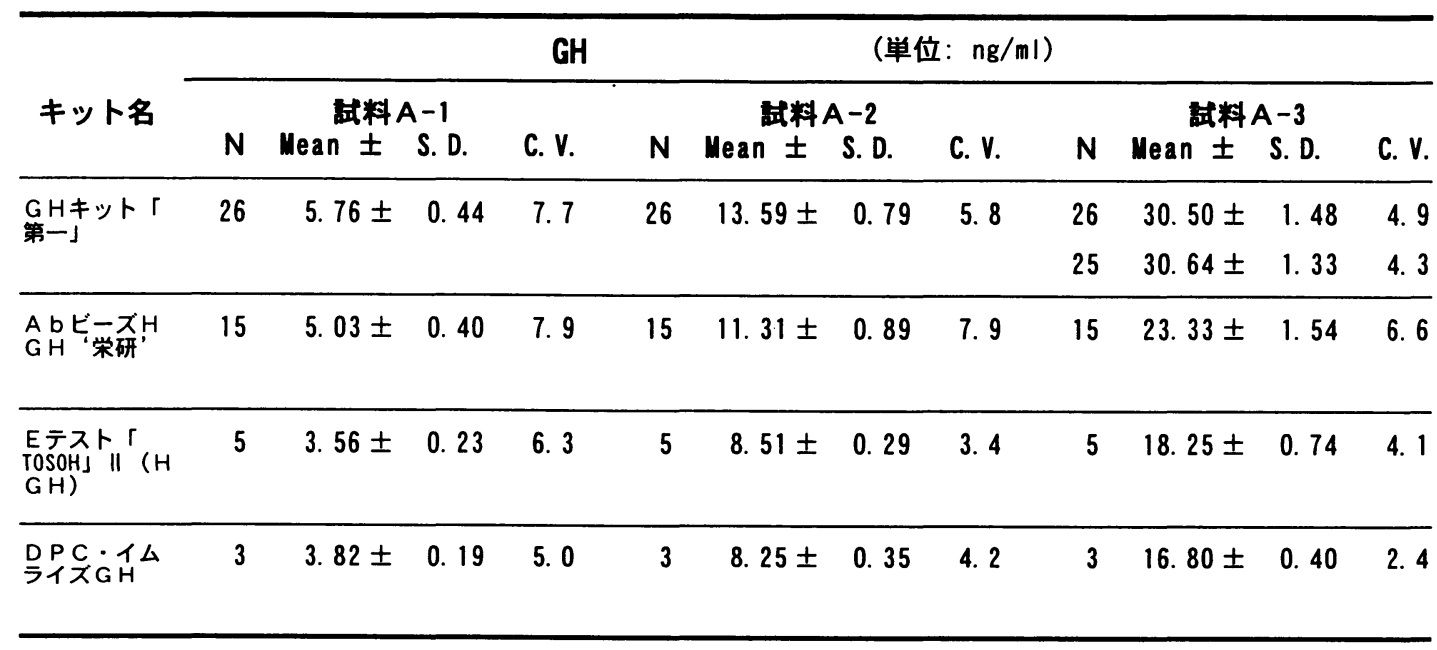

\begin{tabular}{|c|c|c|c|c|c|c|c|c|c|c|c|c|}
\hline \multirow{3}{*}{ キット名 } & \multicolumn{12}{|c|}{ ソマトメジン C1 } \\
\hline & \multicolumn{4}{|c|}{ 鼓料 $A-1$} & \multicolumn{4}{|c|}{ 試料 A-2 } & \multicolumn{4}{|c|}{ 式料A-3 } \\
\hline & $\mathbf{N}$ & Mean \pm & S. D. & C. V. & $\mathbf{N}$ & Mean \pm & S. D. & C. V. & $\mathbf{N}$ & Mean \pm & S. D. & C. V. \\
\hline \multirow{2}{*}{ 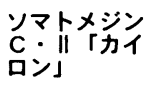 } & 12 & 68. $97 \pm$ & 3. 89 & 5. 6 & \multirow[t]{2}{*}{12} & \multirow[t]{2}{*}{$92.65 \pm$} & \multirow[t]{2}{*}{ 5. 60} & \multirow[t]{2}{*}{ 6. 0} & 12 & 74. $16 \pm$ & 3. 92 & 5. 3 \\
\hline & 11 & $68.15 \pm$ & 2. 78 & 4. 1 & & & & & 11 & 73. $45 \pm$ & 3. 19 & 4. 3 \\
\hline $\begin{array}{l}\text { ソマトメ泣” } \\
\text { II ‘栄研” }\end{array}$ & 3 & 99. $12 \pm$ & 22. 00 & 22. 2 & 3 & $141.91 \pm$ & 24. 54 & 17. 3 & 3 & 140. $90 \pm$ & 18. 35 & 13. 0 \\
\hline 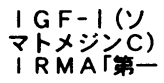 & 3 & $81.07 \pm$ & 3. 68 & 4. 5 & 3 & 109. $81 \pm$ & 7. 15 & 6.5 & 3 & 88. $29 \pm$ & 6.65 & 7. 5 \\
\hline
\end{tabular}




\begin{tabular}{|c|c|c|c|c|c|c|c|c|c|c|c|c|}
\hline \multirow{3}{*}{ キット名 } & \multicolumn{6}{|c|}{ FSH1-78/549 } & \multicolumn{3}{|c|}{ （単位：mIU/mI） } & \multirow{3}{*}{\multicolumn{2}{|c|}{ 試料 $\mathrm{A}-3$}} & \multirow[b]{3}{*}{ C. $\mathbf{V}$} \\
\hline & \multicolumn{4}{|c|}{ 試料 A-1 } & \multicolumn{4}{|c|}{ 試料 A-2 } & \multirow[b]{2}{*}{$\mathbf{N}$} & & & \\
\hline & $\mathbf{N}$ & Mean \pm & S. D. & C. V. & $\mathbf{N}$ & Mean \pm & S. D. & C. V. & & & & \\
\hline $\begin{array}{l}\text { 주ックク-S } \\
\text { FSHキッ }\end{array}$ & 29 & 9. $88 \pm$ & 0.75 & 7. 6 & 29 & $18.77 \pm$ & 1. 62 & 8. 6 & 29 & $50.81 \pm$ & 3. 27 & 6. 4 \\
\hline & 27 & $9.84 \pm$ & 0.42 & 4. 3 & 28 & 18. $49 \pm$ & 0.66 & 3. 6 & 28 & $50.40 \pm$ & 2. 45 & 4. 9 \\
\hline アキシム台 & 14 & 7. $78 \pm$ & 0.59 & 7. 6 & 14 & $15.00 \pm$ & 0.93 & 6. 2 & 14 & 42. $10 \pm$ & 2. 59 & 6. 2 \\
\hline パック & 13 & 7. $67 \pm$ & 0.44 & 5. 8 & 13 & 14. $84 \pm$ & 0.76 & 5. 1 & 13 & $41.62 \pm$ & 1. 96 & 4. 7 \\
\hline $\begin{array}{l}\text { DPC・イム } \\
\text { ライズ } \mathrm{SH}\end{array}$ & 5 & 9. $42 \pm$ & 1. 37 & 14. 6 & 5 & 19. $24 \pm$ & 1. 88 & 9. 8 & 5 & 52. $77 \pm$ & 6.01 & 11.4 \\
\hline $\begin{array}{l}\text { アレグロF S } \\
\text { Hキット }\end{array}$ & 4 & $6.06 \pm$ & 0.67 & 11.0 & 4 & $11.07 \pm$ & 0.79 & 7. 1 & 4 & $25.00 \pm$ & 1. 40 & 5. 6 \\
\hline $\operatorname{IMx}_{\text {タイナナバック }} \mathrm{FH}$ & 3 & 8. $05 \pm$ & 0.61 & 7. 6 & 3 & $15.84 \pm$ & 0.65 & 4. 1 & 3 & 44. $30 \pm$ & 2. 41 & 5. 5 \\
\hline $\begin{array}{l}\text { リアグノスト } \\
\text { FSH }\end{array}$ & 2 & $7.05 \pm$ & 0.92 & 13. 0 & 2 & 13. $30 \pm$ & 1. 13 & 8. 5 & 2 & 32. $40 \pm$ & 0.57 & 1. 7 \\
\hline $\begin{array}{l}\text { Eテスト' } \\
\text { TOSOH」 } \\
\text { SH) }\end{array}$ & 2 & $10.65 \pm$ & 0.35 & 3. 3 & 2 & 18. $15 \pm$ & 0.78 & 4. 3 & 2 & $47.60 \pm$ & 1. 56 & 3. 3 \\
\hline $\begin{array}{l}\text { テクニコンイ } \\
\text { 幺人゙ト F S H } \\
\text { テスト }\end{array}$ & 2 & 8. $30 \pm$ & 0.14 & 1. 7 & 2 & 16. $10 \pm$ & 0.14 & 0.9 & 2 & 43. $00 \pm$ & 0.28 & 0.7 \\
\hline ビトロスF S & 2 & 5. $44 \pm$ & 0.06 & 1. 0 & 2 & $11.85 \pm$ & 0.07 & 0.6 & 2 & 34. $30 \pm$ & 0.28 & 0.8 \\
\hline $\begin{array}{l}\text { デルフィアF } \\
\text { S H }\end{array}$ & 2 & $6.95 \pm$ & 0.36 & 5. 2 & 2 & 13. $15 \pm$ & 0.77 & 5. 9 & 2 & 34. $67 \pm$ & 0.80 & 2. 3 \\
\hline $\begin{array}{l}\text { エクルーシス } \\
\text { III F S }\end{array}$ & 2 & 8. $71 \pm$ & 0.01 & 0.2 & 2 & $17.29 \pm$ & 0.58 & 3. 4 & 2 & 43. $90 \pm$ & 0.35 & 0.8 \\
\hline 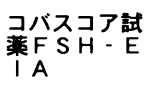 & 1 & 10. 10 & 0.00 & 0.0 & 1 & 22. 60 & 0.00 & 0.0 & 1 & 57. 50 & 0.00 & 0.0 \\
\hline $\begin{array}{l}\text { IMx } \mathrm{x} \text {-SELECT F } \\
\text { SH・タイナ } \\
\text { バック }\end{array}$ & 1 & 7. 87 & 0.00 & 0.0 & 1 & 15. 30 & 0.00 & 0.0 & 1 & 41.09 & 0.00 & 0.0 \\
\hline ルミノマスタ & 1 & 6.69 & 0.00 & 0.0 & 1 & 13.64 & 0.00 & 0.0 & 1 & 36.65 & 0.00 & 0.0 \\
\hline $\begin{array}{l}\text { アマライトF } \\
\text { SH }\end{array}$ & 1 & 5. 92 & 0.00 & 0.0 & 1 & 13. 20 & 0.00 & 0.0 & 1 & 31. 30 & 0.00 & 0.0 \\
\hline
\end{tabular}


FSH2-94/632

(単位: $m|U / m|$ )

\begin{tabular}{|c|c|c|c|c|c|c|c|c|c|c|c|c|}
\hline \multirow[t]{2}{*}{ キット名 } & \multicolumn{4}{|c|}{ 試料 A-1 } & \multicolumn{4}{|c|}{ 試料 A-2 } & \multicolumn{4}{|c|}{ 試料 A-3 } \\
\hline & $\mathbf{N}$ & Mean \pm & S. D. & C. v. & $\mathbf{N}$ & Mean \pm & S. D. & C. v. & $\mathrm{N}$ & Mean \pm & S. D. & C. v. \\
\hline \multirow{2}{*}{$\begin{array}{l}\text { ケミルミAC } \\
S-F S H\end{array}$} & 15 & 7. $72 \pm$ & 0.25 & 3. 3 & 15 & 18. $38 \pm$ & 1. 38 & 7. 5 & 15 & 58. $99 \pm$ & 3. 47 & 5. 9 \\
\hline & & & & & 13 & 18. $42 \pm$ & 0.67 & 3. 6 & 14 & 58. $28 \pm$ & 2. 21 & 3. 8 \\
\hline $\begin{array}{l}\text { ケミルミAC } \\
S-F S H(\text { F } \\
\text { シタウルス) }\end{array}$ & 3 & 7. $54 \pm$ & 0.65 & 8. 6 & 3 & 18. $16 \pm$ & 0.26 & 1.4 & 3 & 58. $38 \pm$ & 0.87 & 1. 5 \\
\hline
\end{tabular}

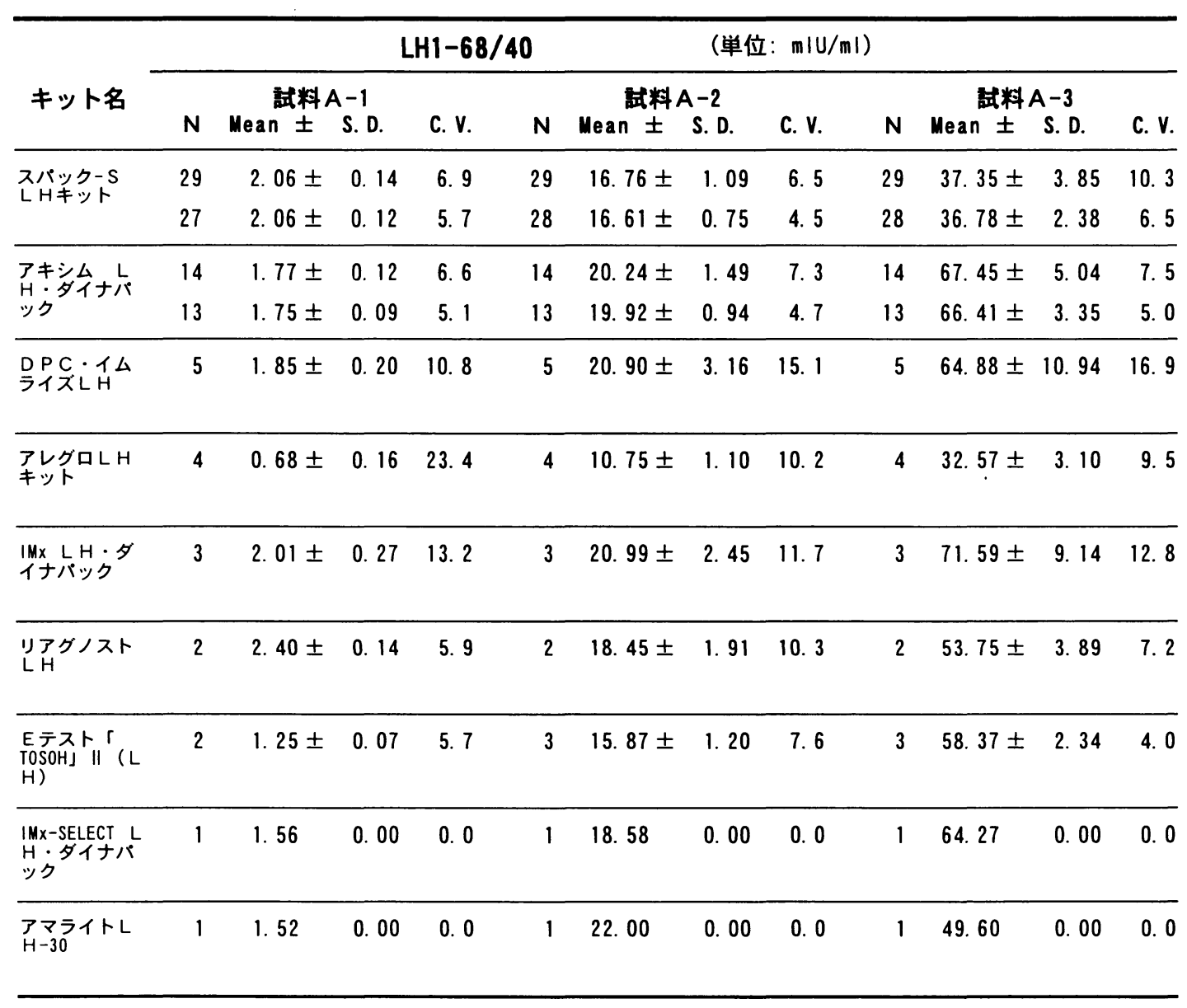




\begin{tabular}{|c|c|c|c|c|c|c|c|c|c|c|c|c|}
\hline \multirow{3}{*}{ キット名 } & \multicolumn{6}{|c|}{ LH3-80/552 } & \multicolumn{3}{|c|}{ （単位：m|U/mI） } & & & \\
\hline & \multicolumn{4}{|c|}{ 試料 A-1 } & \multicolumn{4}{|c|}{ 試料 A-2 } & \multicolumn{4}{|c|}{ 試料 A-3 } \\
\hline & $\mathbf{N}$ & Mean \pm & S. D. & C. V. & $\mathbf{N}$ & Mean \pm & S. D. & C. V. & $\mathbf{N}$ & Mean \pm & S. D. & C. $v$. \\
\hline \multirow{2}{*}{$\begin{array}{l}\text { ケミルミAC } \\
S-L H \|\end{array}$} & 15 & 1. $70 \pm$ & 0.21 & 12. 4 & 15 & 21. $72 \pm$ & 2. 08 & 9. 6 & 15 & 72. $19 \pm$ & 5. 62 & 7. 8 \\
\hline & 14 & 1. $73 \pm$ & 0.16 & 9.5 & 14 & 22. $13 \pm$ & 1. 39 & 6.3 & 14 & 71. $35 \pm$ & 4. 77 & 6. 7 \\
\hline $\begin{array}{l}\text { ケミルミAC } \\
\mathrm{S}-\mathrm{L} H \| \mathrm{H}(\text { ( } \\
\text { シタウルス) }\end{array}$ & 3 & 1. $71 \pm$ & 0.01 & 0.3 & 3 & 23. $49 \pm$ & 1. 17 & 5. 0 & 3 & 74. $65 \pm$ & 1.06 & 1. 4 \\
\hline $\begin{array}{l}\text { テクニコンイ } \\
\text { ムノト LHテ } \\
\text { スト }\end{array}$ & 2 & 1. $30 \pm$ & 0.14 & 10. 9 & 2 & 22. $15 \pm$ & 1. 77 & 8. 0 & 2 & 70. $80 \pm$ & 3. 54 & 5. 0 \\
\hline ビトロスし H & 2 & 1. $47 \pm$ & 0.19 & 13.0 & 2 & 20. $75 \pm$ & 0.78 & 3.7 & 2 & $65.45 \pm$ & 0.21 & 0.3 \\
\hline デルフィアL & 2 & 1. $65 \pm$ & 0.07 & 4. 3 & 2 & 18. $08 \pm$ & 1. 52 & 8. 4 & 2 & 58. $65 \pm$ & 3. 32 & 5. 7 \\
\hline $\begin{array}{l}\text { ルミノマスタ } \\
\text { ー「しH」 }\end{array}$ & 1 & 1. 80 & 0.00 & 0.0 & 1 & 18.02 & 0.00 & 0.0 & 1 & 60.87 & 0.00 & 0.0 \\
\hline $\begin{array}{l}コ ハ ゙ ス コ ア L ~ \\
H \|-E \text { । A }\end{array}$ & 1 & 0.90 & 0.00 & 0.0 & 1 & 8. 00 & 0.00 & 0.0 & 1 & 17. 10 & 0.00 & 0.0 \\
\hline $\begin{array}{l}\text { エクルーシス } \\
\text { LH }\end{array}$ & 1 & 1. 66 & 0.00 & 0.0 & 1 & 21. 16 & 0.00 & 0.0 & 1 & 66.79 & 0.00 & 0.0 \\
\hline
\end{tabular}




\begin{tabular}{|c|c|c|c|c|c|c|c|c|c|c|c|c|}
\hline \multirow{3}{*}{ キット名 } & \multicolumn{12}{|c|}{ プロラクチン1-NIH4 } \\
\hline & \multicolumn{4}{|c|}{ 試料 $A-1$} & \multicolumn{4}{|c|}{ 試料 A-2 } & \multicolumn{4}{|c|}{ 試料 A-3 } \\
\hline & $\mathbf{N}$ & Mean \pm & S. D. & C. V. & $\mathbf{N}$ & Mean \pm & S. D. & C. V. & $\mathbf{N}$ & Mean \pm & S. D. & C. V. \\
\hline $\begin{array}{l}\text { プロラクチン } \\
\text { ॥リアビース }\end{array}$ & 4 & 13. $89 \pm$ & 0.43 & 3. 1 & 4 & 42. $23 \pm$ & 1. 83 & 4. 3 & 4 & $94.22 \pm$ & 2. 47 & 2. 6 \\
\hline
\end{tabular}

\begin{tabular}{|c|c|c|c|c|c|c|c|c|c|c|c|c|}
\hline \multirow{3}{*}{ キット名 } & \multicolumn{6}{|c|}{ プロラクチン2-75/504 } & \multicolumn{3}{|c|}{ （単位：ng/ml） } & & & \\
\hline & \multicolumn{4}{|c|}{ 尌料 $A-1$} & \multicolumn{4}{|c|}{ 尌料A-2 } & \multicolumn{4}{|c|}{ 試料 A-3 } \\
\hline & $\mathbf{N}$ & Mean \pm & S. D. & C. V. & $\mathbf{N}$ & Mean \pm & S. D. & C. V. & $N$ & Mean \pm & S. D. & C. V. \\
\hline \multirow{2}{*}{$\begin{array}{l}\text { スバッククS } \\
\text { ンキットク手 }\end{array}$} & 26 & 5. $71 \pm$ & 0.57 & 10. 0 & 26 & 17. $52 \pm$ & 1. 62 & 9. 2 & 26 & 39. $33 \pm$ & 3. 16 & 8. 0 \\
\hline & 24 & 5. $73 \pm$ & 0.37 & 6. 5 & 25 & 17. $70 \pm$ & 1. 39 & 7. 8 & 24 & 39. $32 \pm$ & 2. 55 & 6. 5 \\
\hline 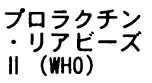 & 1 & 6. 30 & 0.00 & 0.0 & 1 & 20. 70 & 0.00 & 0.0 & 1 & 52. 40 & 0.00 & 0.0 \\
\hline
\end{tabular}

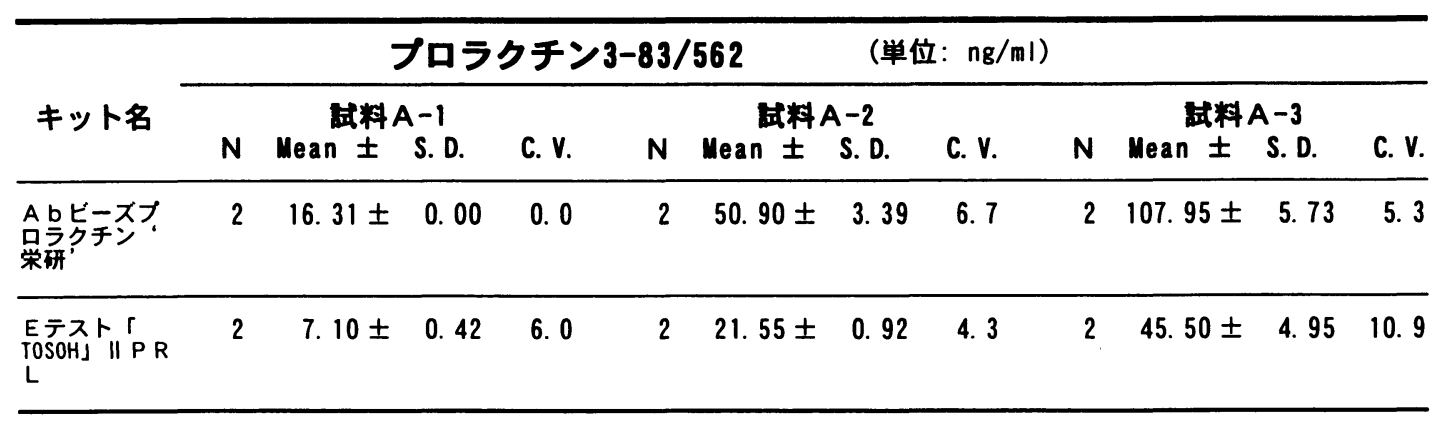




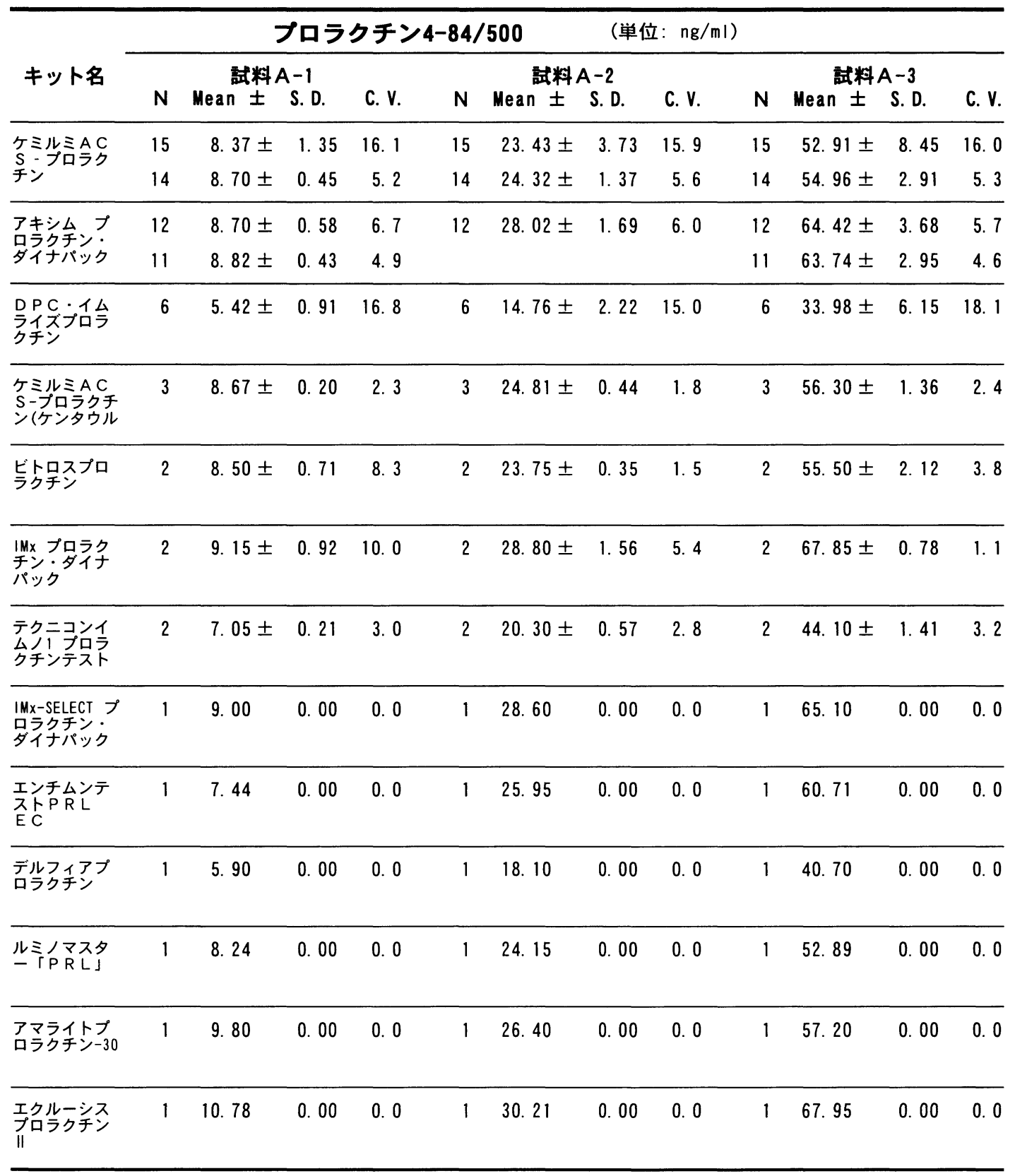




\section{キット名試料A-1 鼓A-2 料A-3}

$\mathbf{N}$ Mean \pm S. D. $\quad$ C. V. $\mathbf{N}$ Mean \pm S. D. C. V. $\mathbf{N}$ Mean \pm S. D. C. V.

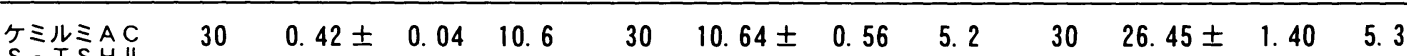

S-TSHII $28 \quad 0.41+0.02 \quad 5.5 \quad 29-10.57 \pm 0.39-3.7 \quad 29 \quad 26.26 \pm 0.97$

\begin{tabular}{|c|c|c|c|c|c|c|c|c|c|c|c|c|}
\hline & & & & & & & & & $2 J$ & & & \\
\hline \multirow{2}{*}{$\begin{array}{l}\text { TSH.リア } \\
\text { ビーズ\| }\end{array}$} & 17 & 0. $38 \pm$ & 0.05 & 12. 3 & 17 & 8. $53 \pm$ & 0.46 & 5. 4 & 17 & 22. $91 \pm$ & 1. 74 & 7. 6 \\
\hline & 16 & $0.37 \pm$ & 0.03 & 9. 0 & 16 & 8. $46 \pm$ & 0.35 & 4. 1 & 16 & 22. $58 \pm$ & 1. 16 & 5. 1 \\
\hline $\begin{array}{l}\text { アキシム } \\
\text { SH・ダナ } \\
\text { パック }\end{array}$ & 12 & $0.37 \pm$ & 0.02 & 5. 6 & 12 & 8. $21 \pm$ & 0.39 & 4. 8 & 12 & 25. $59 \pm$ & 1. 32 & 5. 2 \\
\hline
\end{tabular}

\begin{tabular}{|c|c|c|c|c|c|c|c|c|c|c|c|c|}
\hline \multirow{2}{*}{$\begin{array}{l}\text { スパックーS } \\
\text { TSHキット }\end{array}$} & 11 & $0.42 \pm$ & 0.02 & 5. 4 & 11 & 9. $70 \pm$ & 0.70 & 7. 2 & 11 & $25.61 \pm$ & 1. 52 & 6. 0 \\
\hline & 10 & $0.41 \pm$ & 0.02 & 3. 8 & 10 & 9. $53 \pm$ & 0.42 & 4. 4 & 10 & 25. $25 \pm$ & 1. 02 & 4. 0 \\
\hline \multirow{2}{*}{$\begin{array}{l}\text { リアグノスト } \\
\mathrm{t} T \mathrm{~T} \text { S }\end{array}$} & 7 & $0.44 \pm$ & 0.12 & 27.4 & 7 & 10. $35 \pm$ & 0.55 & 5. 3 & 7 & $25.06 \pm$ & 1. 10 & 4. 4 \\
\hline & 6 & $0.49 \pm$ & 0.06 & 12. 8 & & & & & & & & \\
\hline $\begin{array}{l}\text { アレグロHS } \\
\text { ト TSHキッ }\end{array}$ & 7 & $0.38 \pm$ & 0.04 & 11.0 & 7 & 8. $53 \pm$ & 1. 32 & 15.4 & 7 & $20.72 \pm$ & 2. 48 & 11.9 \\
\hline $\begin{array}{l}\text { DPC・イム } \\
\text { ライズHS } \\
\text { TSH }\end{array}$ & 5 & 0. $37 \pm$ & 0.02 & 5. 6 & 5 & 9. $49 \pm$ & 0.41 & 4. 3 & 5 & $25.61 \pm$ & 1. 43 & 5. 6 \\
\hline
\end{tabular}

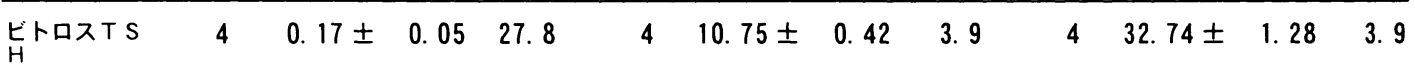

\begin{tabular}{|c|c|c|c|c|c|c|c|c|c|c|c|}
\hline $\begin{array}{l}\text { ケミルミAC } \\
S-T S H \|( \\
\text { ケンタウルス) }\end{array}$ & 4 & $0.44 \pm$ & 0.01 & 2. 9 & 4 & $11.73 \pm$ & 0.28 & 2. 4 & 4 & 27. $11 \pm$ & 0.61 \\
\hline $\begin{array}{l}\text { エクルーシス } \\
\text { TS H }\end{array}$ & 4 & 0. $39 \pm$ & 0.02 & 5. 3 & 4 & 8. $65 \pm$ & 0.67 & 7. 8 & 4 & 23. $98 \pm$ & 2. 49 \\
\hline
\end{tabular}

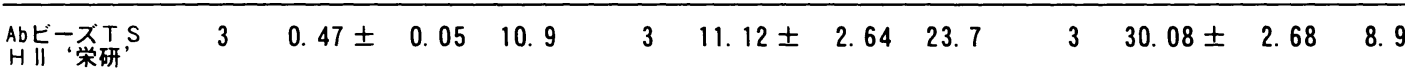

\begin{tabular}{|c|c|c|c|c|c|c|c|c|c|c|c|c|}
\hline 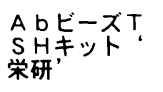 & 3 & $0.39 \pm$ & 0.13 & 32. 7 & 3 & 8. $04 \pm$ & 2. 26 & 28. 1 & 3 & 22. $64 \pm$ & 5. 39 & 23. 8 \\
\hline $\begin{array}{l}\text { Eテスト }{ }^{\top}{ }^{\text {TOSOHJ }} \\
S \mathrm{H})\end{array}$ & 3 & $0.54 \pm$ & 0.00 & 0.7 & 3 & $10.69 \pm$ & 0.20 & 1. 8 & 3 & 29. $66 \pm$ & 1. 81 & 6. 1 \\
\hline $\begin{array}{l}\text { ルミパルス } \mathrm{T} \\
\mathrm{S} H\end{array}$ & 3 & $0.41 \pm$ & 0.01 & 2. 0 & 3 & 8. $05 \pm$ & 0.07 & 0.8 & 3 & $23.86 \pm$ & 0.59 & 2. 5 \\
\hline $\begin{array}{l}\text { アマライトT } \\
\text { SH-30 }\end{array}$ & 3 & $0.22 \pm$ & 0.03 & 11.7 & 3 & $11.67 \pm$ & 0.21 & 1. 8 & 3 & 30. $27 \pm$ & 0.38 & 1. 3 \\
\hline $\begin{array}{l}\operatorname{IMx} T \mathrm{~T} H \\
\text { タイナパック } \\
\text { (NEW) }\end{array}$ & 2 & $0.43 \pm$ & 0.06 & 15. 0 & 2 & 8. $90 \pm$ & 1. 15 & 13.0 & 2 & 28. $90 \pm$ & 5. 15 & 17.8 \\
\hline
\end{tabular}


（続き）

\section{T3}

(単位: $\mathrm{ng} / \mathrm{ml}$ )

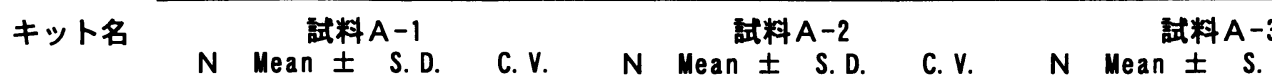

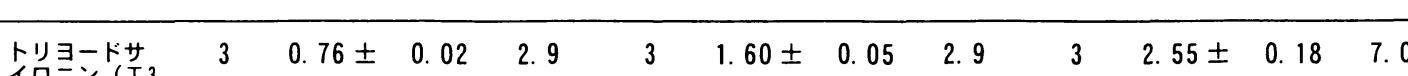

イロ学研, ( T

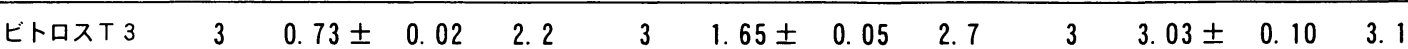

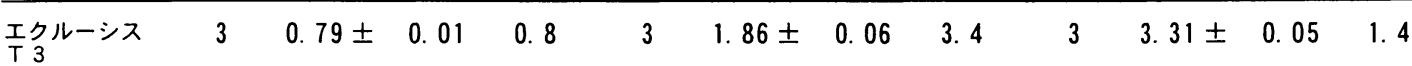

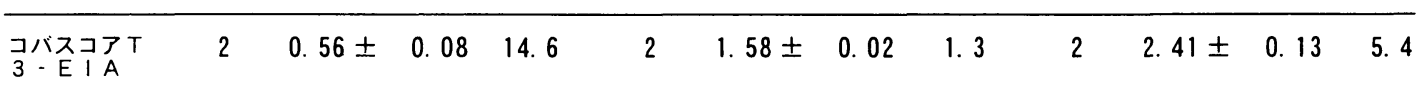

\begin{tabular}{|c|c|c|c|c|c|c|c|c|c|c|}
\hline マライトT & 2 & $0.78 \pm$ & 0.08 & 9. 9 & 2 & 1. $59 \pm$ & 0.13 & 8. 0 & 2 & 2. $82 \pm 0.13$ \\
\hline
\end{tabular}

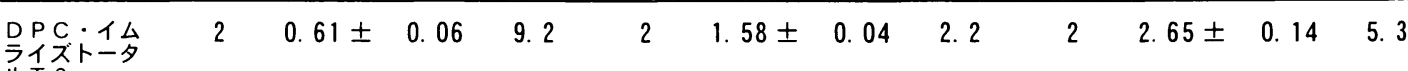
ルイ

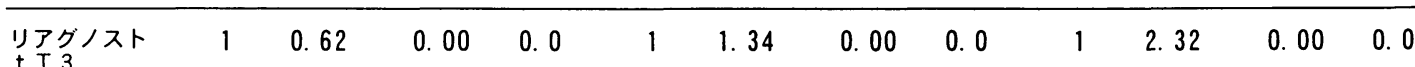

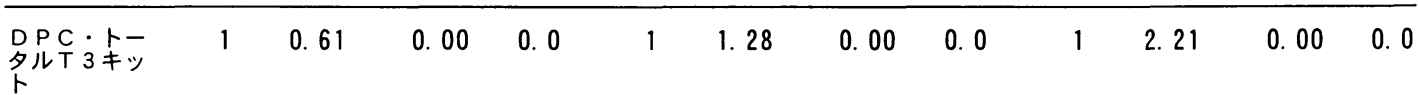

$\begin{array}{lllllllllllll}\text { テクニコンイ } & 1 & 0.57 & 0.00 & 0.0 & 1 & 1.22 & 0.00 & 0.0 & 1 & 2.15 & 0.00 & 0.0\end{array}$
スト

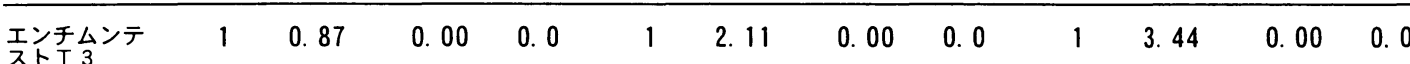

\begin{tabular}{|c|c|c|c|c|c|c|c|c|c|c|c|}
\hline $\begin{array}{l}\text { IMx T-3・ダ } \\
\text { イナパック }\end{array}$ & 1 & 0.48 & 0.00 & 0.0 & 1 & 1. 22 & 0.00 & 0.0 & 1 & 2. 24 & 0.00 \\
\hline
\end{tabular}

\begin{tabular}{|c|c|c|c|c|c|c|c|c|c|c|c|c|}
\hline $\begin{array}{c}\text { グラオザイム } \\
{[\text { New }] \text { T } 3}\end{array}$ & 1 & 0.90 & 0.00 & 0.0 & 1 & 1. 75 & 0.00 & 0.0 & 1 & 3. 10 & 0.00 & 0.0 \\
\hline
\end{tabular}




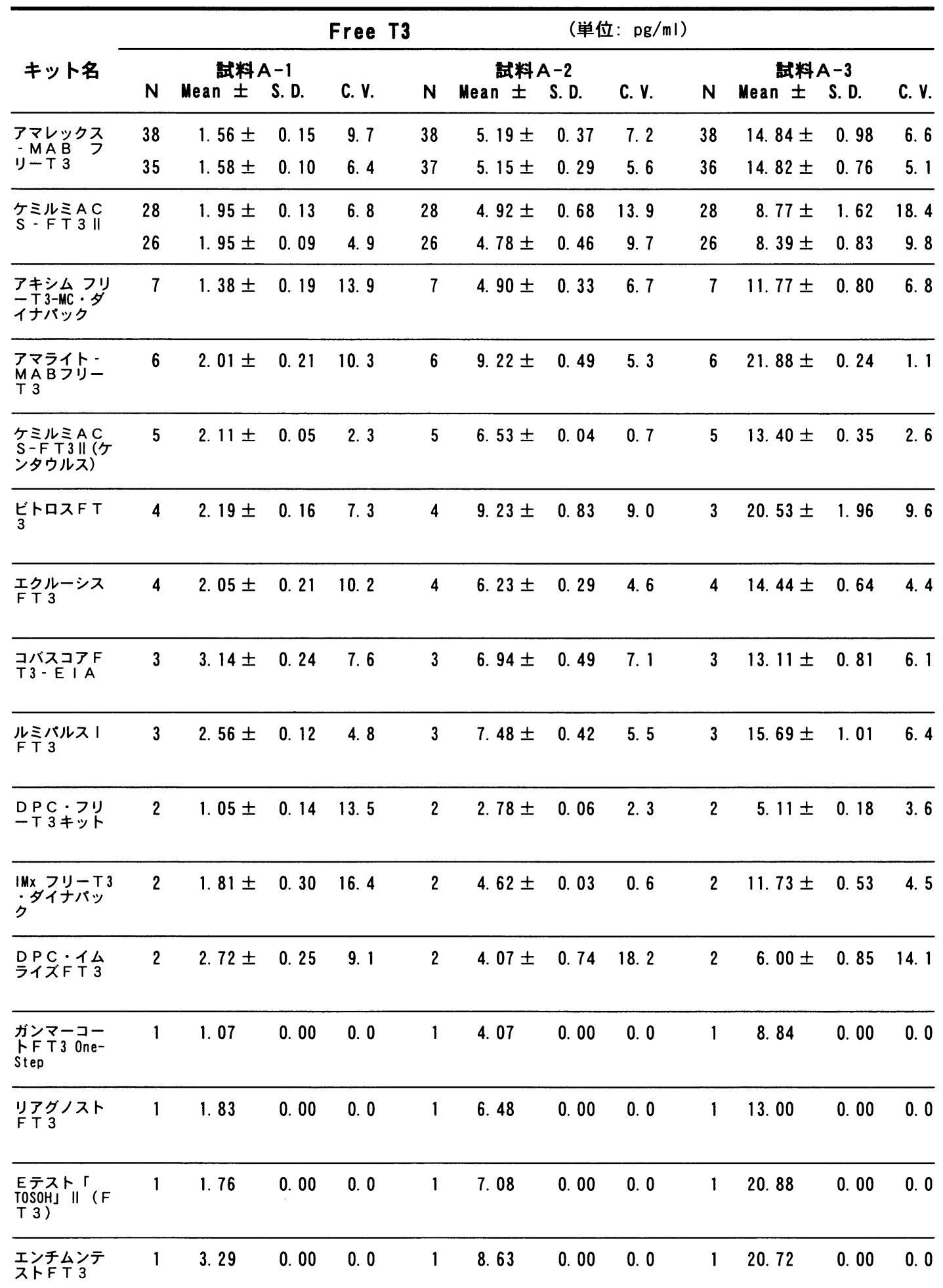


Free T3

(単位: $p g / m I)$

キット名

式料 $A-1$

式料 A-3

$N$ Mean \pm S.D. C.V. $N$ Mean \pm S.D. C.V. $N$ Mean \pm S. D. C. $v$.

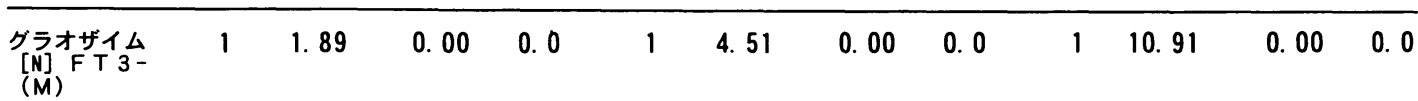

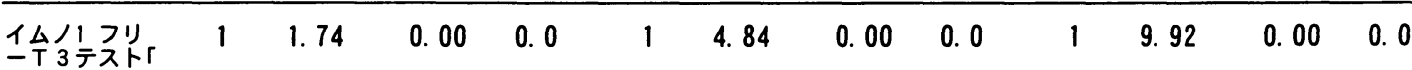
パイエル」

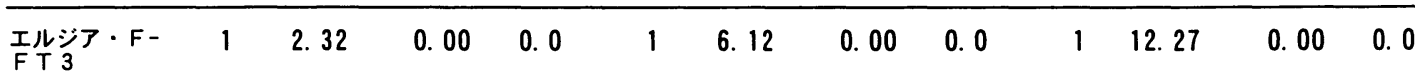

$\begin{array}{lllllllllllll}\text { ケミルミAC } & 1 & 1.94 & 0.00 & 0.0 & 1 & 4.85 & 0.00 & 0.0 & 1 & 8.96 & 0.00 & 0.0\end{array}$

T4

(単位: $\mu \mathrm{g} / \mathrm{d} \mathrm{l}$ )

\section{キット名 式料A-1 料A-2 㑘料A-3}

\begin{tabular}{|c|c|c|c|c|c|c|c|c|c|c|c|c|}
\hline & $\mathbf{N}$ & Mean \pm & S. D. & C. v. & $\mathbf{N}$ & Mean \pm & S. D. & C. V. & $\mathbf{N}$ & Mean \pm & S. D. & C. V. \\
\hline \multirow{2}{*}{ ケミルミAC } & 28 & 2. $74 \pm$ & 0.32 & 11.8 & 28 & 7. $85 \pm$ & 0.47 & 6.0 & 28 & 14. $42 \pm$ & 0.73 & 5. 1 \\
\hline & 26 & 2. $74 \pm$ & 0.25 & 9. 0 & 26 & 7. $94 \pm$ & 0.35 & 4. 4 & 27 & 14. $50 \pm$ & 0.60 & 4. 1 \\
\hline \multirow{2}{*}{$\begin{array}{l}\text { スパックT4 } \\
\text { R|Aキット }\end{array}$} & 18 & 3. $17 \pm$ & 0.33 & 10. 5 & 18 & 8. $29 \pm$ & 0.74 & 9. 0 & 18 & 16. $03 \pm$ & 1. 50 & 9. 4 \\
\hline & 17 & 3. $13 \pm$ & 0.27 & 8. 7 & 17 & 8. $40 \pm$ & 0.60 & 7. 2 & 16 & 16. $04 \pm$ & 0.77 & 4. 8 \\
\hline $\begin{array}{l}\text { アキジム } \\
4\end{array}$ 多イナパ & 8 & 3. $82 \pm$ & 0.29 & 7. 6 & 8 & 8. $70 \pm$ & 0.31 & 3. 6 & 8 & 17. $22 \pm$ & 0.33 & 1. 9 \\
\hline
\end{tabular}

\begin{tabular}{|c|c|c|c|c|c|c|c|c|c|c|c|c|}
\hline \multirow{2}{*}{ アマレックス } & \multirow[t]{2}{*}{7} & \multirow[t]{2}{*}{ 3. $21 \pm$} & \multirow[t]{2}{*}{0.21} & \multirow[t]{2}{*}{6.6} & \multirow{2}{*}{$\begin{array}{l}7 \\
6\end{array}$} & \multirow{2}{*}{$\begin{array}{l}7.41 \pm \\
7.54 \pm\end{array}$} & \multirow{2}{*}{$\begin{array}{l}0.39 \\
0.16\end{array}$} & \multirow{2}{*}{$\begin{array}{l}5.2 \\
2.2\end{array}$} & \multirow[t]{2}{*}{7} & \multirow[t]{2}{*}{ 13. $76 \pm$} & \multirow[t]{2}{*}{0.37} & \multirow[t]{2}{*}{ 2. 7} \\
\hline & & & & & & & & & & & & \\
\hline $\begin{array}{l}T-4 \\
\text { ビース }\end{array}$ & 6 & 3. $35 \pm$ & 0.28 & 8. 4 & 6 & 7. $35 \pm$ & 0.29 & 4. 0 & 6 & 14. $81 \pm$ & 1.09 & 7. 3 \\
\hline
\end{tabular}

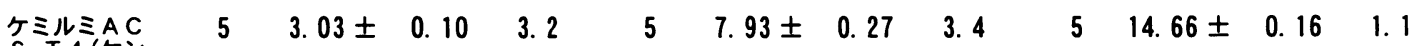
$\mathrm{S}-\mathrm{T} 4$ (ケン タウルス)

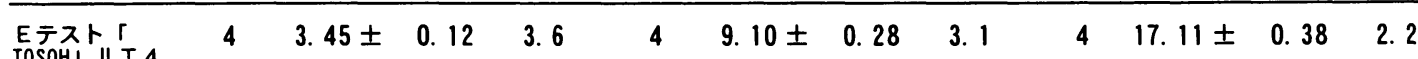

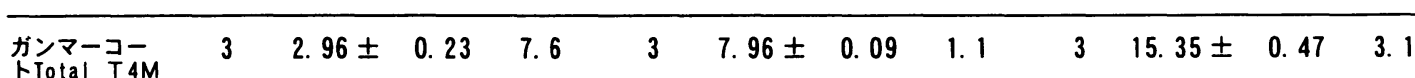

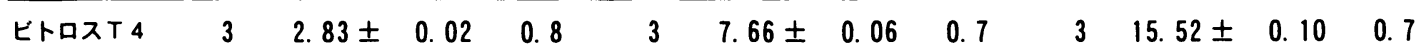


T4

キット名 試料A-1 試料A-2

(単位: $\mu \mathrm{g} / \mathrm{d} \mathrm{I}$ )

試料 A-3

$\mathrm{N}$ Mean \pm S. D. C.V. $\mathrm{N}$ Mean \pm S.D. C.V. $\mathrm{N}$ Mean \pm S.D. C.V.

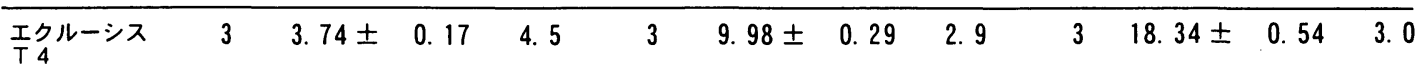

\begin{tabular}{|c|c|c|c|c|c|c|c|c|c|c|c|c|}
\hline $\begin{array}{l}\text { コバスコア試 } \\
\text { 笙T4 } \\
\text { A }\end{array}$ & 2 & 2. $95 \pm$ & 0.07 & 2. 4 & 2 & 8. $10 \pm$ & 0.14 & 1. 7 & 2 & 16. $13 \pm$ & 0. 32 & 2. 0 \\
\hline
\end{tabular}

\begin{tabular}{|c|c|c|c|c|c|c|c|c|c|c|c|}
\hline $\begin{array}{l}\text { TDX T-4・吕 } \\
\text { イナバック }\end{array}$ & 2 & 3. $97 \pm$ & 0.61 & 15. 3 & 2 & 8. $32 \pm$ & 0.26 & 3. 1 & 2 & $17.05 \pm$ & 0.20 \\
\hline
\end{tabular}

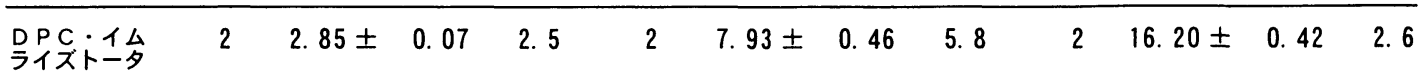
ル十 4

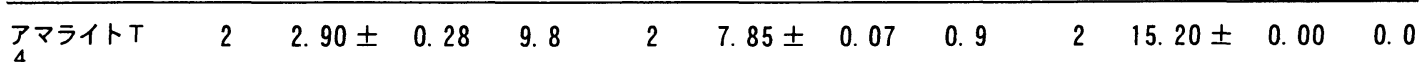

\begin{tabular}{lllllllllllll}
\hline リアグノスト & 1 & 3.33 & 0.00 & 0.0 & 1 & 8.67 & 0.00 & 0.0 & 1 & 18.10 & 0.00 & 0.0
\end{tabular}

\begin{tabular}{|c|c|c|c|c|c|c|c|c|c|c|c|c|}
\hline $\begin{array}{l}\text { D P C P ト トー } \\
\text { 多ルT } 4 \text { キッ } \\
\text { ト }\end{array}$ & 1 & 3. 20 & 0.00 & 0.0 & 1 & 7. 88 & 0.00 & 0.0 & 1 & 14. 05 & 0.00 & 0.0 \\
\hline
\end{tabular}

\begin{tabular}{|c|c|c|c|c|c|c|c|c|c|c|c|}
\hline ロキシン & 1 & 2. 86 & 0.00 & 0.0 & 1 & 7. 38 & 0.00 & 0.0 & 1 & 16. 02 & 0.00 \\
\hline
\end{tabular}

\begin{tabular}{|c|c|c|c|c|c|c|c|c|c|c|c|}
\hline $\begin{array}{l}\text { グラオザイム } \\
{\left[\begin{array}{l}\text { New }] \text { T 4- } \\
\text { (M) }\end{array}\right.}\end{array}$ & 1 & 3. 27 & 0.00 & 0.0 & 1 & 9. 27 & 0.00 & 0.0 & 1 & 17. 33 & 0.00 \\
\hline
\end{tabular}
(M)

\begin{tabular}{lllllllllllll}
\hline エンチムンテ & 1 & 2.87 & 0.00 & 0.0 & 1 & 7.63 & 0.00 & 0.0 & 1 & 15.22 & 0.00 & 0.0
\end{tabular}

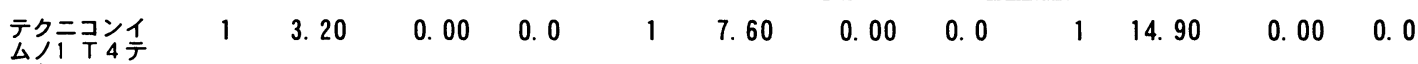
スト 


\begin{tabular}{|c|c|c|c|c|c|c|c|c|c|c|c|c|}
\hline \multirow{3}{*}{ キット名 } & \multicolumn{5}{|c|}{ Free T4 } & \multicolumn{4}{|c|}{ （単位：ng/dl) } & & & \\
\hline & \multicolumn{4}{|c|}{ 試料 A-1 } & \multicolumn{4}{|c|}{ 試料 A-2 } & \multicolumn{4}{|c|}{ 試料 $A-3$} \\
\hline & $\mathbf{N}$ & Mean \pm & S. D. & C. V. & $\mathbf{N}$ & Mean \pm & S. D. & C. V. & $\mathbf{N}$ & Mean \pm & S. D. & C. V. \\
\hline $\begin{array}{l}\text { モデルF T4キ } \\
\text { ット }\end{array}$ & 1 & 0. 38 & 0.00 & 0.0 & 1 & 3. 60 & 0.00 & 0.0 & 0 & 0.00 & 0.00 & 0.0 \\
\hline $\begin{array}{l}\text { エンチムンテ } \\
\text { ストF T } 4\end{array}$ & 1 & 0.53 & 0.00 & 0.0 & 1 & 1. 86 & 0.00 & 0.0 & 1 & 5. 01 & 0.00 & 0.0 \\
\hline $\begin{array}{l}\text { グラオザイム } \\
{[\mathrm{N}] \mathrm{F} T 4-} \\
(\mathrm{M})\end{array}$ & 1 & 0.43 & 0.00 & 0.0 & 1 & 1. 67 & 0.00 & 0.0 & 1 & 6. 28 & 0.00 & 0.0 \\
\hline $\begin{array}{l}\text { テクニコンイ } \\
\text { 厶ノフリー } \\
\text { T4 テスト }\end{array}$ & 1 & 0.47 & 0.00 & 0.0 & 1 & 1. 69 & 0.00 & 0.0 & 1 & 3. 90 & 0.00 & 0.0 \\
\hline エルジア・F- & 1 & 0.47 & 0.00 & 0.0 & 1 & 1. 04 & 0.00 & 0.0 & 1 & 4. 20 & 0.00 & 0.0 \\
\hline
\end{tabular}




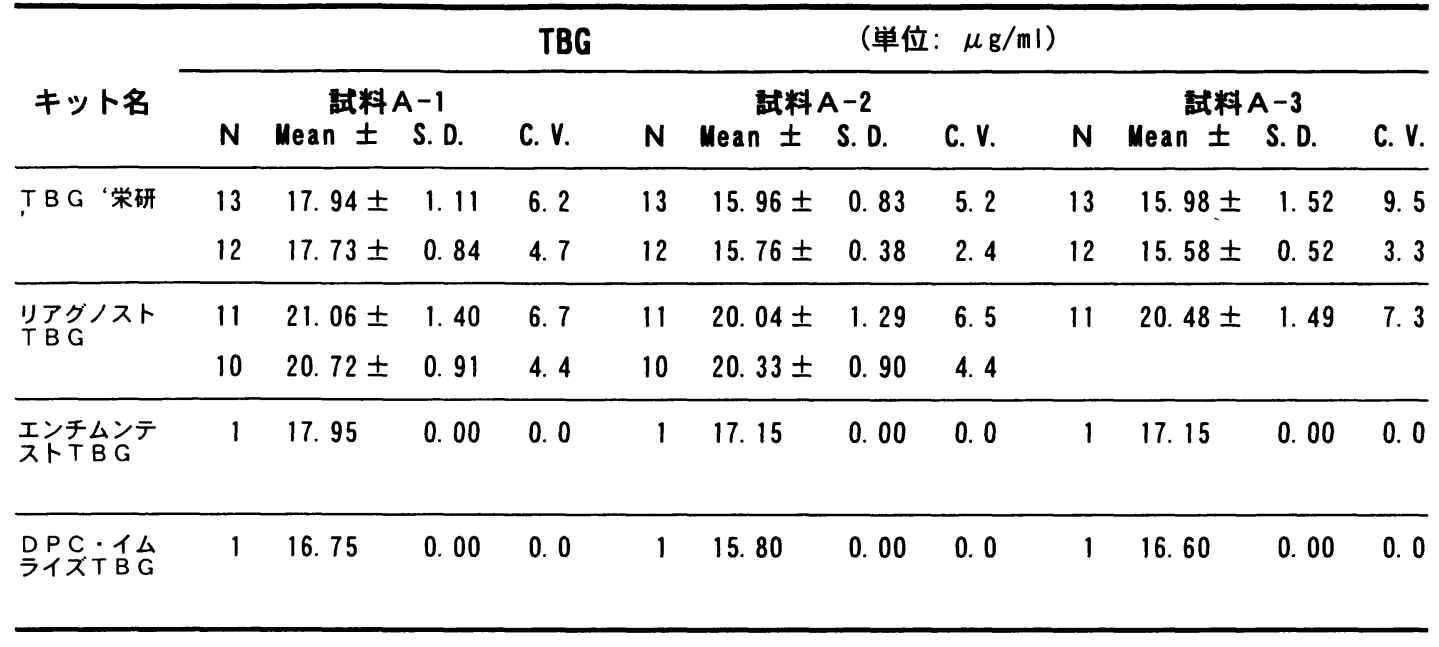

\begin{tabular}{|c|c|c|c|c|c|c|c|c|c|c|c|}
\hline \multirow{3}{*}{ キット名 } & \multicolumn{5}{|c|}{ カルシトニン } & \multicolumn{4}{|c|}{ （単位：pg/ml) } & & \multirow[b]{3}{*}{ C. V. } \\
\hline & \multicolumn{4}{|c|}{ 試料 A-1 } & \multicolumn{4}{|c|}{ 試料 A-2 } & \multirow[b]{2}{*}{$\mathbf{N}$} & & \\
\hline & $\mathbf{N}$ & Mean \pm & S. D. & C. V. & $\mathbf{N}$ & Mean \pm & S. D. & C. V. & & \begin{tabular}{cc}
\multicolumn{2}{c}{ 試料 A-3 } \\
Mean \pm & S.D.
\end{tabular} & \\
\hline \multirow{2}{*}{$\begin{array}{l}\text { カルシトミン } \\
\text { RIA } \text { 「ミミ } \\
\text { ビシ」 }\end{array}$} & \multirow[t]{2}{*}{12} & \multirow[t]{2}{*}{$70.24 \pm$} & \multirow[t]{2}{*}{ 6. 61} & \multirow[t]{2}{*}{ 9. 4} & 12 & $461.62 \pm$ & 29.84 & 6. 5 & 12 & $1032.66 \pm 115.21$ & 11. 2 \\
\hline & & & & & 11 & $467.85 \pm$ & 21.59 & 4. 6 & 11 & 1008. $26 \pm 82.12$ & 8. 1 \\
\hline $\begin{array}{l}\text { カルシトニン } \\
\text { キット「第一 } \\
\text { 」 }\end{array}$ & 5 & $147.42 \pm$ & 46. 90 & 31.8 & 5 & $381.44 \pm$ & 89. 14 & 23.4 & 5 & $713.08 \pm 161.59$ & 22. 7 \\
\hline $\begin{array}{l}\text { イムノカルシ } \\
\text { トニン }\end{array}$ & 4 & 78. $28 \pm$ & 15. 24 & 19. 5 & 4 & 286. $98 \pm$ & 45.57 & 15. 9 & 4 & $641.13 \pm 98.89$ & 15. 4 \\
\hline $\begin{array}{l}\text { カルシトニン } \\
\text { キット栄研 }\end{array}$ & 2 & $107.50 \pm$ & 12. 02 & 11. 2 & 2 & 454. $75 \pm$ & 44.19 & 9.7 & 2 & $820.20 \pm 6.79$ & 0.8 \\
\hline
\end{tabular}




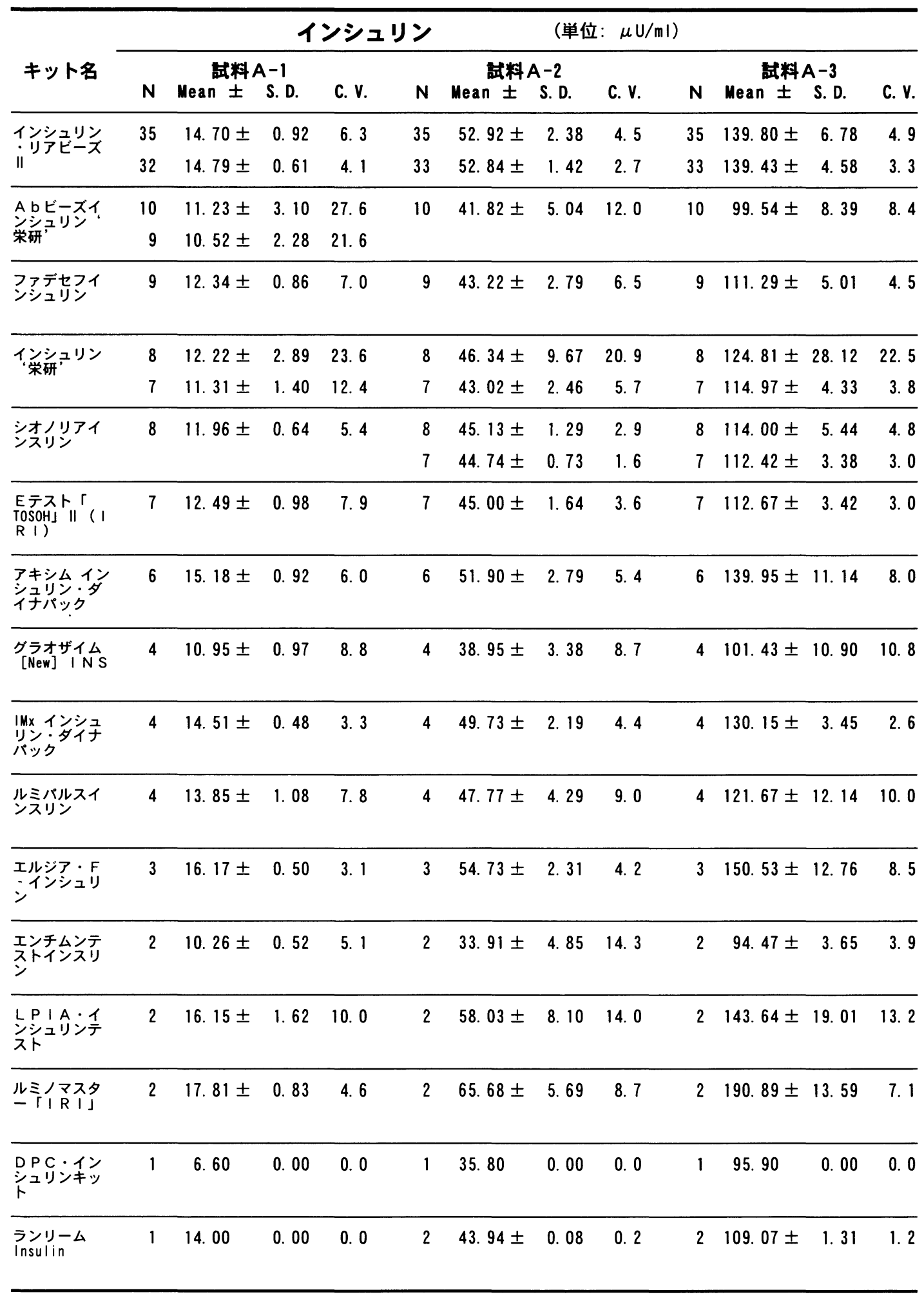




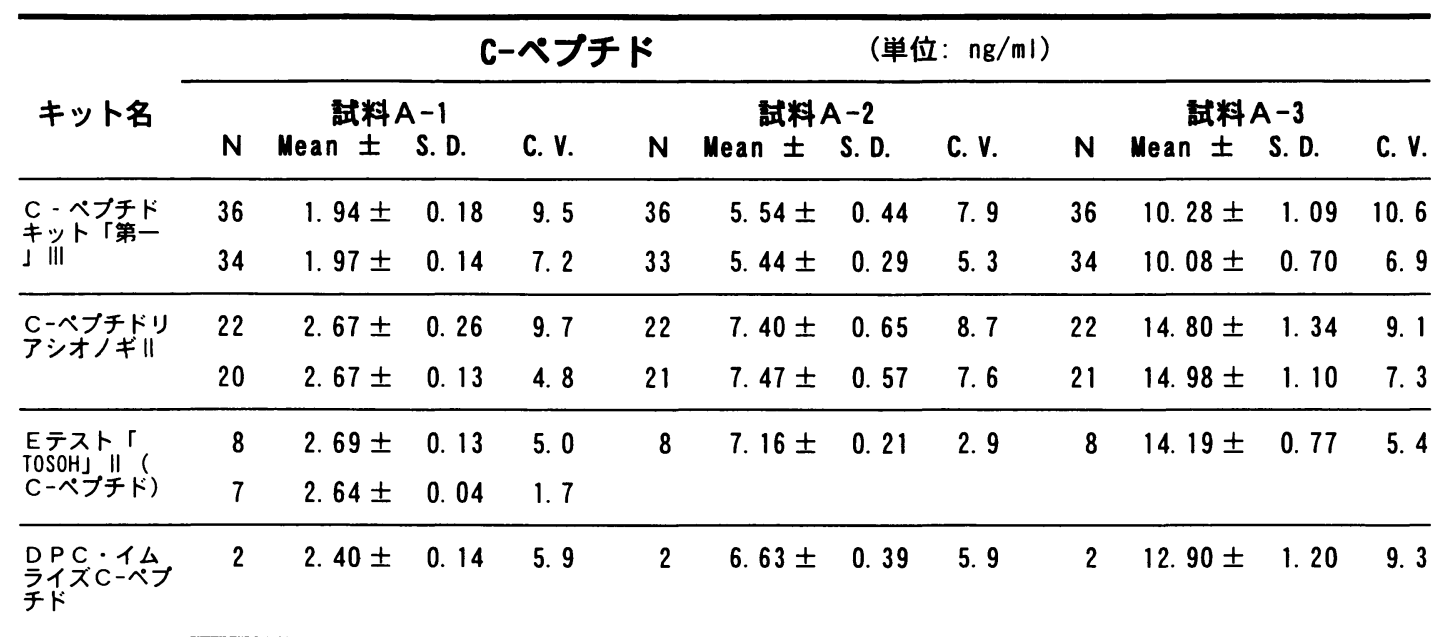

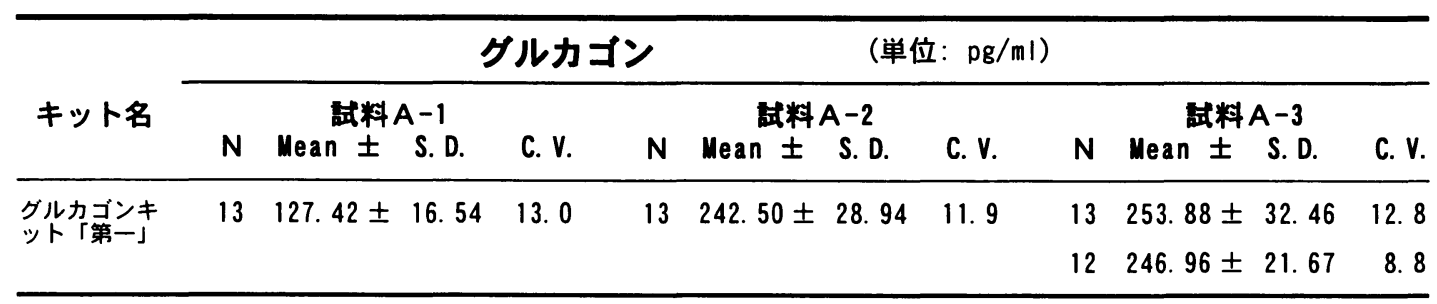

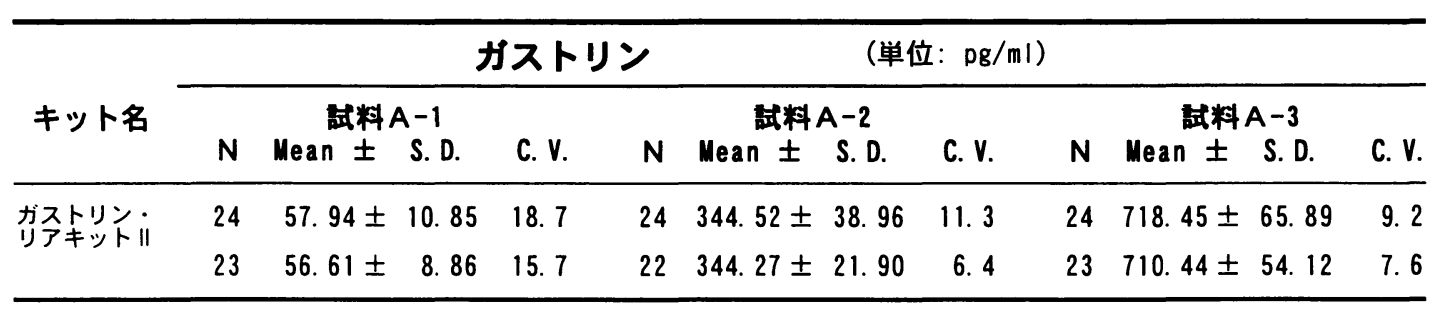




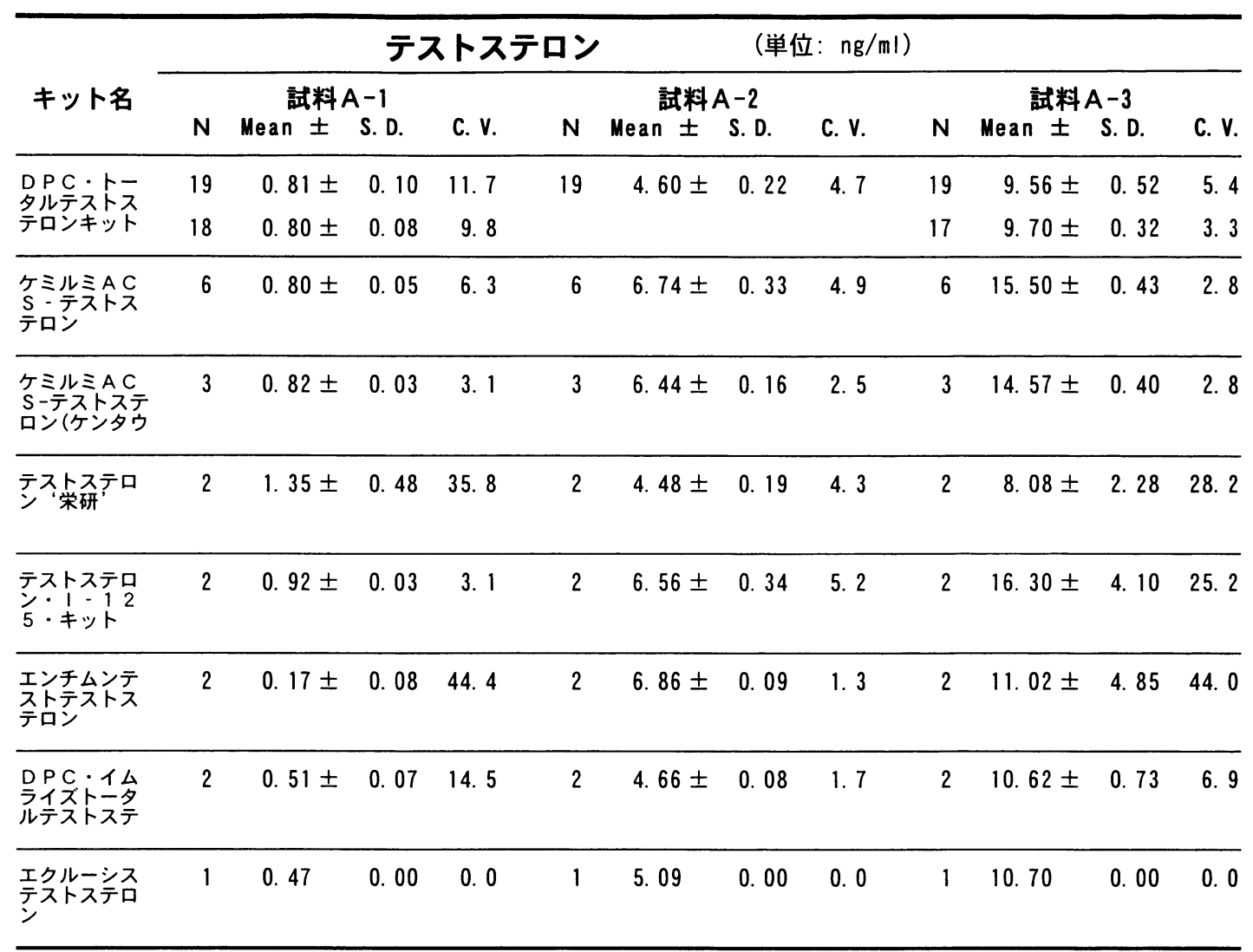

\begin{tabular}{|c|c|c|c|c|c|c|c|c|c|c|c|c|}
\hline \multirow{3}{*}{ キット名 } & \multicolumn{12}{|c|}{ Freeテストステロン } \\
\hline & \multicolumn{4}{|c|}{ 試料 $A-1$} & \multicolumn{4}{|c|}{ 試料 A-2 } & \multicolumn{4}{|c|}{ 試料 A-3 } \\
\hline & $\mathrm{N}$ & Mean \pm & S. D. & C. V. & $\mathrm{N}$ & Mean \pm & S. D. & C. V. & $\mathrm{N}$ & Mean \pm & S. D. & C. V. \\
\hline \multirow{2}{*}{ 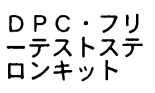 } & \multirow[t]{2}{*}{9} & \multirow[t]{2}{*}{ 1. $03 \pm$} & \multirow[t]{2}{*}{0.17} & \multirow[t]{2}{*}{ 16. 8} & \multirow[t]{2}{*}{9} & \multirow[t]{2}{*}{$10.28 \pm$} & \multirow[t]{2}{*}{0.81} & \multirow[t]{2}{*}{7.8} & 9 & 31. $39 \pm$ & 1. 76 & 5. 6 \\
\hline & & & & & & & & & 8 & $30.91 \pm$ & 1. 09 & 3. 5 \\
\hline
\end{tabular}




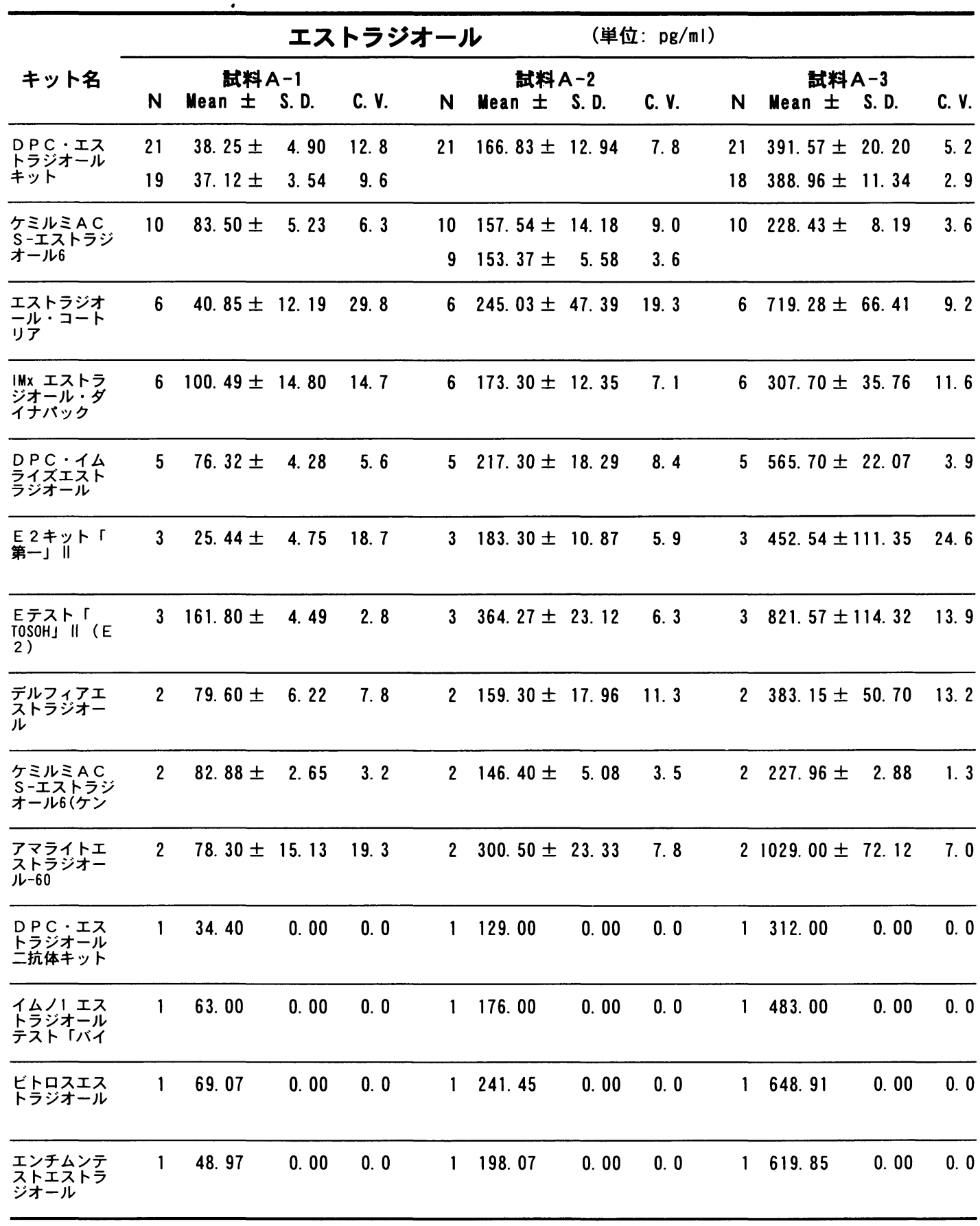




\section{プロゲステロン (単位: $n g / m 1)$}

キット名 試料A-1 試料A-2

試料 A-3

$N$ Mean \pm S. D. $\quad$ C. v. $N$ Mean \pm S.D. C. V. $N$ Mean \pm S. D. C. V.

\begin{tabular}{|c|c|c|c|c|c|c|c|c|c|c|c|c|}
\hline \multirow{2}{*}{$\begin{array}{l}\text { DPC・プロ } \\
\text { D゙ストテロシキ } \\
\text { ット }\end{array}$} & 26 & $0.80 \pm$ & 0.06 & 7. 3 & 26 & 6. $98 \pm$ & 0.45 & 6.4 & 26 & 18. $08 \pm$ & 1.61 & 8. 9 \\
\hline & 25 & $0.80 \pm$ & 0.05 & 6. 6 & 24 & 6. $96 \pm$ & 0.34 & 4. 9 & 25 & 17. $86 \pm$ & 1. 20 & 6.7 \\
\hline \multirow{2}{*}{$\begin{array}{l}\text { ケミルミAC } \\
\text { S ニ㐋ゲス } \\
\text { テロシ }\end{array}$} & 11 & 1. $00 \pm$ & 0.10 & 9. 5 & \multirow[t]{2}{*}{11} & \multirow[t]{2}{*}{$6.56 \pm$} & \multirow[t]{2}{*}{0.78} & \multirow[t]{2}{*}{11.8} & \multirow[t]{2}{*}{11} & \multirow[t]{2}{*}{ 15. $69 \pm$} & \multirow[t]{2}{*}{0.93} & \multirow[t]{2}{*}{ 5. 9} \\
\hline & 10 & $0.98 \pm$ & 0.05 & 5. 4 & & & & & & & & \\
\hline
\end{tabular}

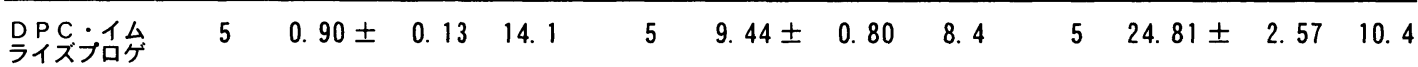

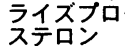

\begin{tabular}{|c|c|c|c|c|c|c|c|c|c|c|c|c|}
\hline $\begin{array}{l}\text { Eテスト「 } \\
\text { TOSOHJ II (プ } \\
\text { ロゲステロシ }\end{array}$ & 3 & 0. $50 \pm$ & 0.09 & 18. 3 & 3 & 7. $50 \pm$ & 1. 49 & 19. 9 & 3 & 24. $34 \pm$ & 2. 63 & 10. 8 \\
\hline $\begin{array}{l}\text { ケミルミAC } \\
\text { Sラプロゲステテ } \\
\text { ロン(ケンタウ }\end{array}$ & 3 & 1. $06 \pm$ & 0.05 & 5. 0 & 3 & 7. $27 \pm$ & 0.51 & 7. 1 & 3 & 16. $29 \pm$ & 0.62 & 3. 8 \\
\hline $\begin{array}{l}\text { プロゲステロ } \\
\text { ア゙・コートリ }\end{array}$ & 2 & $0.31 \pm$ & 0.01 & 2. 3 & 2 & 8. $43 \pm$ & 0.24 & 2. 9 & 2 & 26. $70 \pm$ & 0.85 & 3. 2 \\
\hline $\begin{array}{l}\text { アマライトプ } \\
\text { ロゲステロン }\end{array}$ & 2 & $0.47 \pm$ & 0.13 & 28.9 & 2 & 5. $69 \pm$ & 1. 25 & 22.0 & 2 & 18. $85 \pm$ & 1. 06 & 5. 6 \\
\hline $\begin{array}{l}\text { プロゲステロ } \\
\text { シキット「第 } \\
\text {-」॥ }\end{array}$ & 1 & 0.67 & 0.00 & 0.0 & 1 & 2. 55 & 0.00 & 0.0 & 1 & 4. 95 & 0.00 & 0.0 \\
\hline
\end{tabular}

\begin{tabular}{|c|c|c|c|c|c|c|c|c|c|c|c|c|}
\hline $\begin{array}{l}\text { エンチムンテ } \\
\text { ストプロゲス } \\
\text { テロン }\end{array}$ & 1 & 0.90 & 0.00 & 0.0 & 1 & 7.85 & 0.00 & 0.0 & 1 & 20. 92 & 0.00 & 0.0 \\
\hline
\end{tabular}

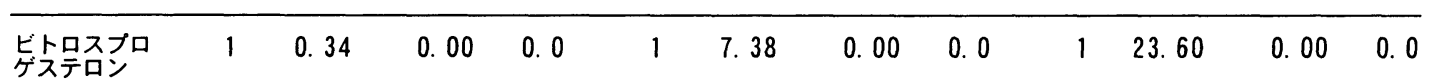

\begin{tabular}{|c|c|c|c|c|c|c|c|c|c|c|c|c|}
\hline $\begin{array}{l}\text { イムノ1 プロ } \\
\text { ゲステロンテ } \\
\text { スト「バイエ }\end{array}$ & 1 & 0.48 & 0.00 & 0.0 & 1 & 6.67 & 0.00 & 0.0 & 1 & 18. 69 & 0.00 & 0.0 \\
\hline $\begin{array}{l}\text { アキシシム プロ } \\
\text { ゲステロン゙ } \\
\text { ダイナバック }\end{array}$ & 1 & 1. 16 & 0.00 & 0.0 & 1 & 10. 25 & 0.00 & 0.0 & 1 & 28. 06 & 0.00 & 0.0 \\
\hline
\end{tabular}

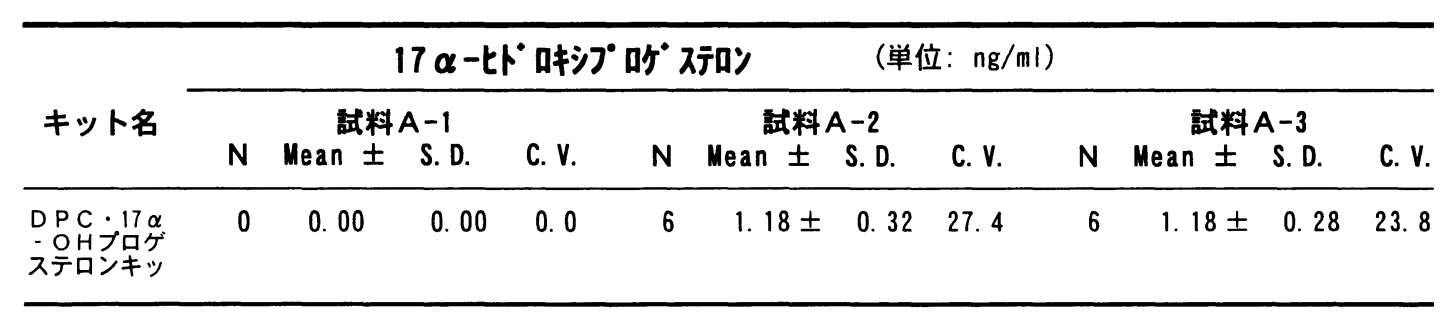




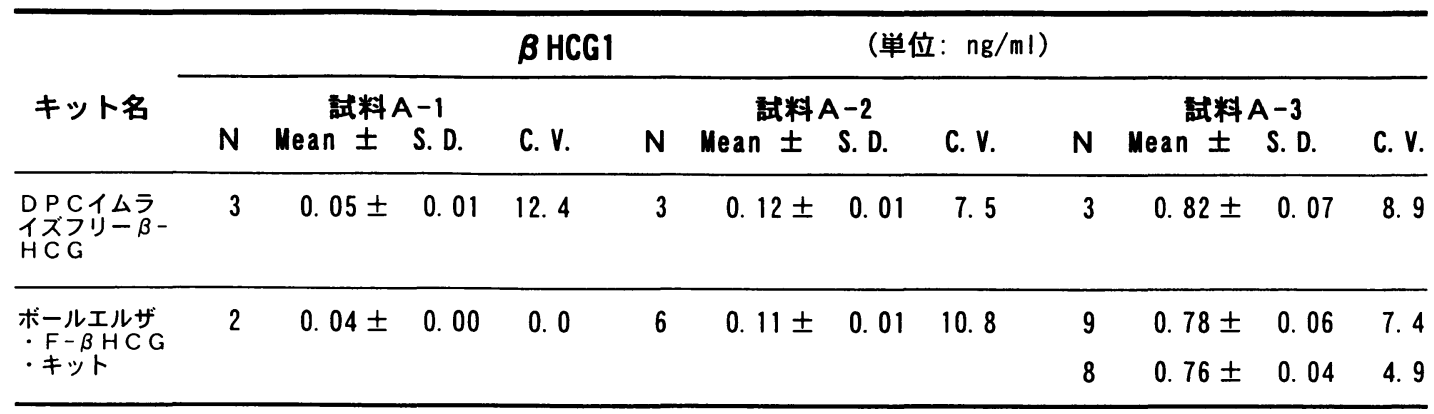

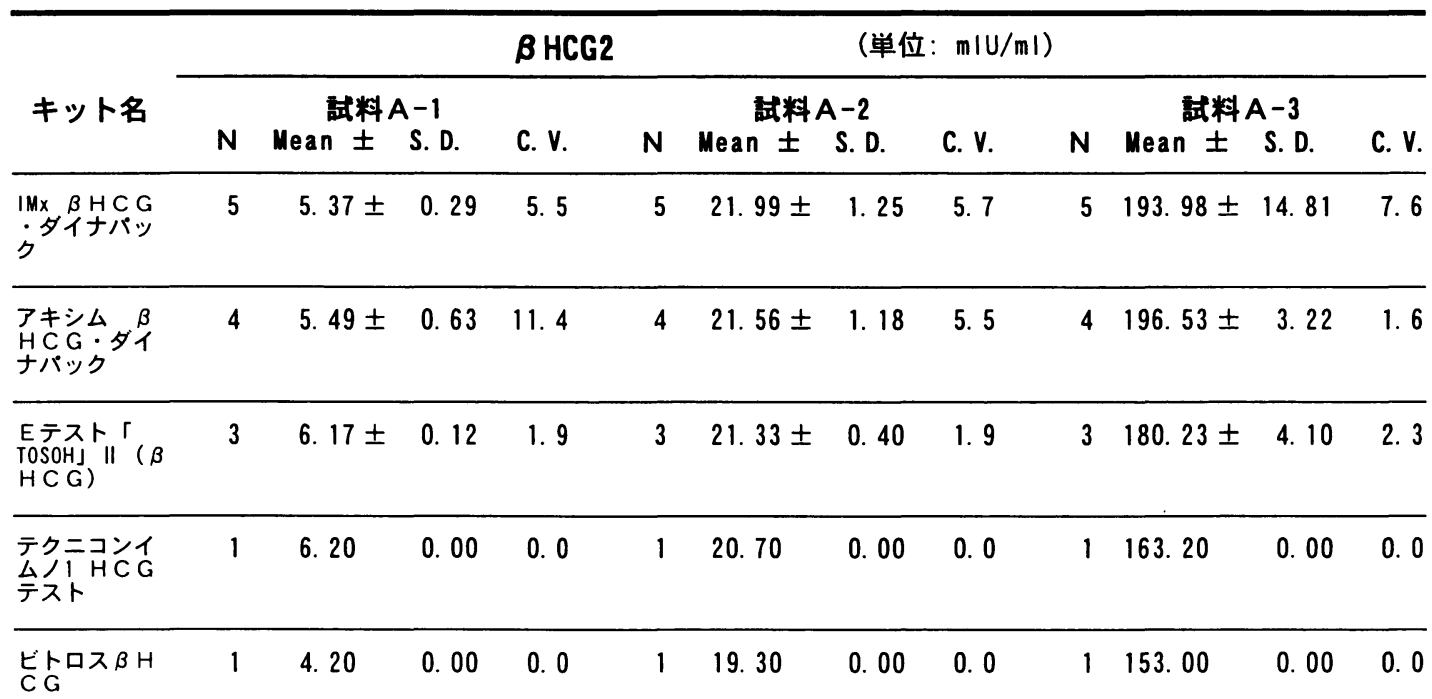

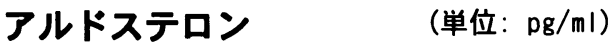

キット名尌料 $A-1 \quad$ 試料 $A-2$ 試料 $A-3$

\begin{tabular}{|c|c|c|c|c|c|c|c|c|c|c|c|}
\hline & $N$ & Mean \pm & S. D. & C. V. & $\mathbf{N}$ & Mean \pm & S. D. & C. V. & $\mathbf{N}$ & Mean \pm S. D. & C. V. \\
\hline \multirow{2}{*}{$\begin{array}{l}\text { スパッグン } \\
\text { ロジキッステ }\end{array}$} & 32 & 77. $24 \pm$ & 14. 59 & 18. 9 & 32 & 213. $83 \pm$ & 38. 64 & 18. 1 & 32 & 527. $45 \pm 108.17$ & 20.5 \\
\hline & 31 & 79. $47 \pm$ & 7. 47 & 9. 4 & 31 & $220.03 \pm$ & 16. 59 & 7. 5 & 30 & $552.40 \pm 38.75$ & 7. 0 \\
\hline \multirow{2}{*}{ 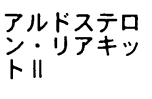 } & 17 & 117. $10 \pm$ & 16. 24 & 13. 9 & 17 & $237.81 \pm$ & 28. 41 & 11.9 & 17 & $516.38 \pm 65.75$ & 12. 7 \\
\hline & 16 & $119.60 \pm$ & 12. 94 & 10.8 & & & & & 16 & $505.78 \pm 50.73$ & 10. 0 \\
\hline 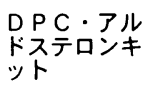 & 2 & $66.50 \pm$ & 14.85 & 22. 3 & 2 & $301.50 \pm$ & 4. 95 & 1.6 & 2 & $711.00 \pm 72.12$ & 10.1 \\
\hline
\end{tabular}




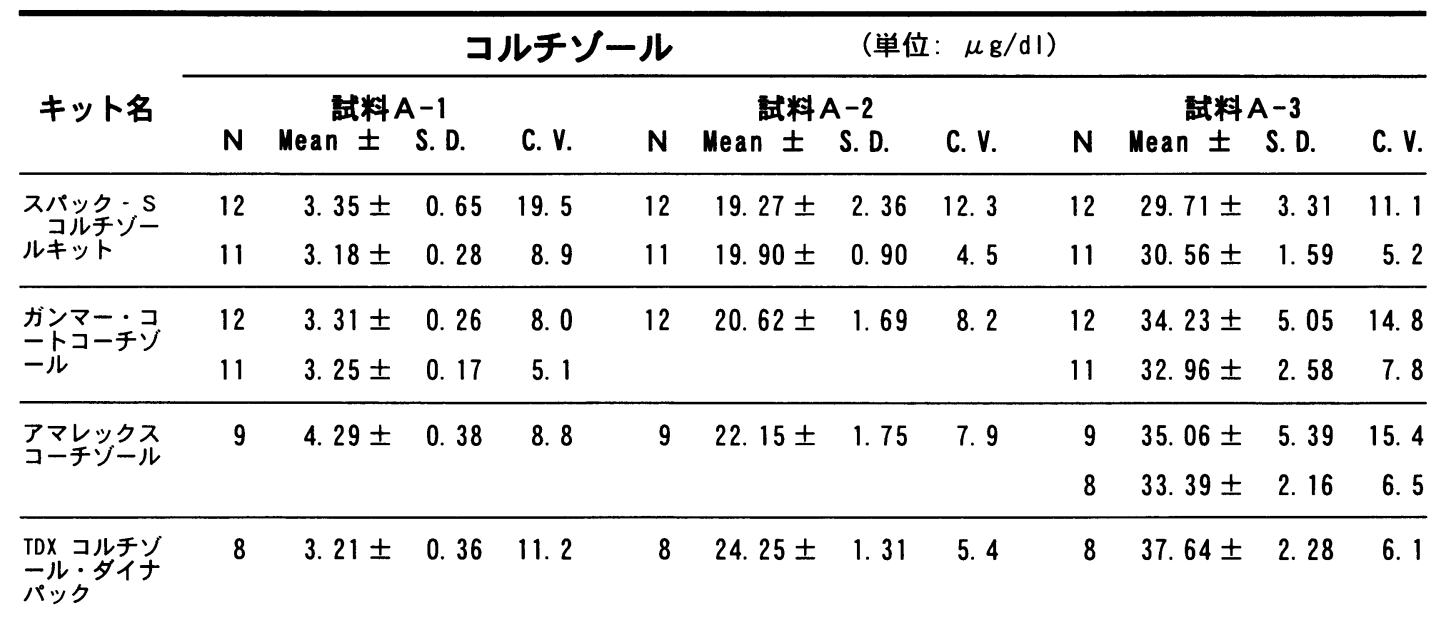

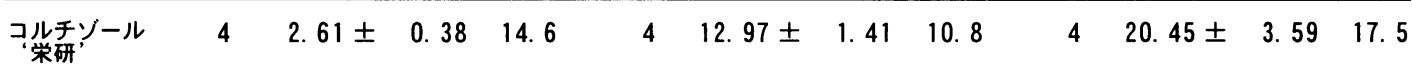

\begin{tabular}{|c|c|c|c|c|c|c|c|c|c|c|c|c|}
\hline $\begin{array}{l}\text { Eテスト「 } \\
\text { TOSOH」 }{ }^{\prime} \text { (コ } \\
\text { ルチソル) }\end{array}$ & 4 & 3. $01 \pm$ & 0.24 & 8. 0 & 4 & 19. $10 \pm$ & 0.96 & 5. 0 & 4 & 29. $54 \pm$ & 1. 41 & 4. 8 \\
\hline
\end{tabular}

\begin{tabular}{|c|c|c|c|c|c|c|c|c|c|c|c|c|}
\hline $\begin{array}{l}\text { エンチムンテ } \\
\text { ストコルチソ } \\
\text { ール }\end{array}$ & 3 & 2. $66 \pm$ & 0.21 & 8. 0 & 3 & 18. $24 \pm$ & 1. 21 & 6.6 & 3 & 29. $20 \pm$ & 1. 82 & 6. 2 \\
\hline
\end{tabular}

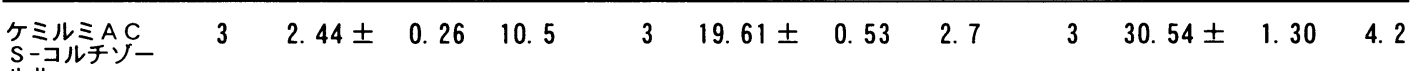
ル॥

\begin{tabular}{|c|c|c|c|c|c|c|c|c|c|c|c|c|}
\hline $\begin{array}{l}\text { DPC・コル } \\
\text { チソールキッ } \\
\text { ト }\end{array}$ & 2 & 2. $74 \pm$ & 0.13 & 4. 6 & 2 & 23. $35 \pm$ & 2. 90 & 12. 4 & 2 & 39. $05 \pm$ & 7. 42 & 19. 0 \\
\hline $\begin{array}{l}\text { E I Aテスト } \\
\text { コルチソール } \\
\text { 「ВMY」 }\end{array}$ & 2 & 3. $30 \pm$ & 0.57 & 17. 1 & 2 & 20. $15 \pm$ & 0.78 & 3. 9 & 2 & 31. $15 \pm$ & 0.21 & 0.7 \\
\hline
\end{tabular}

\begin{tabular}{|c|c|c|c|c|c|c|c|c|c|c|c|c|}
\hline $\begin{array}{l}\text { DPC・イ台 } \\
\text { ライススコル手 } \\
\text { ゾール }\end{array}$ & 2 & 3. $00 \pm$ & 0.14 & 4. 7 & 2 & $20.67 \pm$ & 0.81 & 3. 9 & 2 & 33. $95 \pm$ & 3. 75 & 11.0 \\
\hline
\end{tabular}

\begin{tabular}{|c|c|c|c|c|c|c|c|c|c|c|c|c|}
\hline $\begin{array}{l}\text { ケミルミAC } \\
\text { S-コルチゾー } \\
\text { ル॥（ケシタウ }\end{array}$ & 2 & 2. $82 \pm$ & 0.04 & 1. 3 & 2 & $20.88 \pm$ & 0.83 & 4. 0 & 2 & $34.08 \pm$ & 0.17 & 0.5 \\
\hline $\begin{array}{l}\text { テクニコンイ } \\
\text { ム゙ノ゙ルヂ } \\
\text { ゾールネト }\end{array}$ & 1 & 2. 90 & 0.00 & 0.0 & 1 & 19. 30 & 0.00 & 0.0 & 1 & 30.80 & 0.00 & 0.0 \\
\hline $\begin{array}{l}\text { セディアーコル } \\
\text { チゾール }\end{array}$ & 1 & 5. 60 & 0.00 & 0.0 & 1 & 22. 50 & 0.00 & 0.0 & 1 & 32. 00 & 0.00 & 0.0 \\
\hline $\begin{array}{l}\text { アクセスコル } \\
\text { チソール }\end{array}$ & 1 & 3. 20 & 0.00 & 0.0 & 1 & 24. 20 & 0.00 & 0.0 & 1 & 37.10 & 0.00 & 0.0 \\
\hline
\end{tabular}




\begin{tabular}{|c|c|c|c|c|c|c|c|c|c|c|c|}
\hline \multirow{3}{*}{ キット名 } & \multicolumn{5}{|c|}{ DHEA-S } & \multicolumn{4}{|c|}{ (単位: $\mu \mathrm{g} / \mathrm{dl}$ ) } & \multirow{3}{*}{ 式料 $A-3$} & \multirow[b]{3}{*}{ C. V. } \\
\hline & & 試料 & $A-1$ & & & 試料 & $A-2$ & & & & \\
\hline & $\mathbf{N}$ & Mean \pm & S. D. & C. V. & $\mathbf{N}$ & Mean \pm & S. D. & C. V. & $\mathbf{N}$ & & \\
\hline \multirow{2}{*}{$\begin{array}{l}D P C \cdot D H \\
E A-S \neq ッ \\
F\end{array}$} & \multirow[t]{2}{*}{10} & \multirow[t]{2}{*}{$20.02 \pm$} & \multirow[t]{2}{*}{ 2. 41} & \multirow[t]{2}{*}{12.1} & 10 & 146. $46 \pm$ & 11.79 & 8. 0 & 10 & $530.63 \pm 29.41$ & 5. 5 \\
\hline & & & & & 9 & $143.78 \pm$ & 8. 68 & 6.0 & 9 & $522.92 \pm 17.46$ & 3. 3 \\
\hline 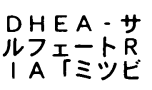 & 2 & 26. $51 \pm$ & 0.27 & 1. 0 & 2 & 228. $14 \pm$ & 9. 32 & 4. 1 & 2 & $634.24 \pm 33.92$ & 5. 3 \\
\hline
\end{tabular}

\begin{tabular}{|c|c|c|c|c|c|c|c|c|c|c|c|c|}
\hline \multirow{3}{*}{ キット名 } & \multicolumn{5}{|c|}{ レニン } & \multicolumn{4}{|c|}{ （単位： $\mathrm{pg} / \mathrm{ml}$ ) } & \multirow{3}{*}{\multicolumn{2}{|c|}{ 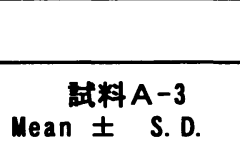 }} & \multirow[b]{3}{*}{ C. $v$} \\
\hline & \multirow[b]{2}{*}{$\mathbf{N}$} & \multicolumn{2}{|c|}{ 試料 A-1 } & \multirow[b]{2}{*}{ C. $\mathbf{v}$. } & \multirow{2}{*}{\multicolumn{3}{|c|}{\begin{tabular}{ccc} 
& \multicolumn{2}{c}{ 试料A-2 } \\
$N$ Mean \pm & S. D.
\end{tabular}}} & \multirow[b]{2}{*}{ c. v. } & \multirow[b]{2}{*}{$\mathbf{N}$} & & & \\
\hline & & Mean \pm & S. D. & & & & & & & & & \\
\hline レニン IRM & 18 & 23. $89 \pm$ & 1. 86 & 7. 8 & 18 & 36. $14 \pm$ & 2. 65 & 7. 3 & 18 & $31.00 \pm$ & 3. 34 & 10.8 \\
\hline & 17 & 24. $21 \pm$ & 1. 30 & 5. 4 & 17 & 36. $49 \pm$ & 2. 26 & 6. 2 & 17 & 31. $54 \pm$ & 2. 47 & 7. 8 \\
\hline
\end{tabular}




\begin{tabular}{|c|c|c|c|c|c|c|c|c|c|c|c|}
\hline \multirow{3}{*}{ キット名 } & \multirow{2}{*}{\multicolumn{3}{|c|}{ 試料 A-1 }} & \multicolumn{8}{|c|}{ （単位： $|\mathrm{U} / \mathrm{m}|$ ) } \\
\hline & & & & \multirow[b]{2}{*}{$\mathbf{N}$} & \multirow{2}{*}{\multicolumn{2}{|c|}{ 試料 A-2 }} & \multirow[b]{2}{*}{ C. V. } & \multirow[b]{2}{*}{$\mathbf{N}$} & \multirow{2}{*}{\multicolumn{2}{|c|}{$\begin{array}{c}\text { 試料 A-3 } \\
\text { Mean 士 S. D. }\end{array}$}} & \multirow[b]{2}{*}{ C. $\mathbf{v}$} \\
\hline & $\mathbf{N}$ & Mean 士 S.D. & C. V. & & & & & & & & \\
\hline \multirow{2}{*}{$\begin{array}{lll}\text { キャップ। } & g \\
E & F E \text { I A }\end{array}$} & 13 & $338.55 \pm 30.81$ & 9.1 & 13 & $112.07 \pm$ & 7.81 & 7. 0 & 13 & $117.37 \pm$ & 9.97 & 8. 5 \\
\hline & 12 & $343.75 \pm 25.55$ & 7. 4 & & & & & & & & \\
\hline \multirow{2}{*}{$\begin{array}{l}\text { ファルマシア } \\
\text { lgEリア }\end{array}$} & 8 & $334.00 \pm 24.24$ & 7. 3 & 8 & 108. $13 \pm$ & 5. 17 & 4. 8 & 8 & $110.88 \pm$ & 6.85 & 6. 2 \\
\hline & 7 & $326.00 \pm 9.40$ & 2. 9 & & & & & & & & \\
\hline \multirow{2}{*}{$\begin{array}{l}\text { シオノリア } \\
\text { g E }\end{array}$} & 8 & $308.44 \pm 20.87$ & 6.8 & 8 & $99.85 \pm$ & 14. 20 & 14. 2 & 8 & $96.43 \pm$ & 16. 10 & 16. 7 \\
\hline & & & & 7 & 104. $09 \pm$ & 8. 23 & 7. 9 & 7 & $101.29 \pm$ & 9. 05 & 8. 9 \\
\hline \multirow{2}{*}{$\begin{array}{l}\text { A b ビーズ I } \\
\text { g Eキッド } \\
\text { 栄研” }\end{array}$} & 8 & $322.77 \pm 13.03$ & 4. 0 & 8 & $105.63 \pm$ & 4. 47 & 4. 2 & 8 & 106. $07 \pm$ & 5. 09 & 4. 8 \\
\hline & 7 & $318.88 \pm 7.54$ & 2. 4 & & & & & 7 & 104. $51 \pm$ & 2.73 & 2. 6 \\
\hline $\begin{array}{l}\text { ケミルミAC } \\
\mathrm{S}=1 \mathrm{gE}\end{array}$ & 7 & $374.57 \pm 7.60$ & 2. 0 & 7 & 109. $87 \pm$ & 2. 72 & 2. 5 & 7 & 109. $23 \pm$ & 3. 94 & 3. 6 \\
\hline $\begin{array}{l}\text { ルミワード( } \\
\text { ( g E E) }\end{array}$ & 6 & 383. $50 \pm 42.20$ & 11.0 & 6 & $120.00 \pm$ & 5. 37 & 4. 5 & 6 & $120.00 \pm$ & 10. 70 & 8. 9 \\
\hline $\begin{array}{l}\text { キャップ। } \mathrm{g} \\
\mathrm{E}\end{array}$ & 4 & $338.67 \pm 29.14$ & 8. 6 & 4 & 128. $30 \pm$ & 5. 80 & 4. 5 & 4 & 128. $70 \pm$ & 7. 26 & 5. 6 \\
\hline 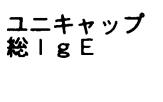 & 4 & $363.63 \pm 10.03$ & 2. 8 & 4 & $112.88 \pm$ & 3. 12 & 2. 8 & 4 & $117.75 \pm$ & 4. 50 & 3. 8 \\
\hline $\begin{array}{l}\text { Eテスト } \\
\text { TOSOH」 } \\
\mathrm{g} \text { E })^{r}\end{array}$ & 3 & $321.90 \pm 52.18$ & 16. 2 & 3 & $117.37 \pm$ & 11. 49 & 9.8 & 3 & $117.60 \pm$ & 11.88 & 10. 1 \\
\hline $\begin{array}{l}\text { グラオザイム } \\
{[\text { New] I g E }}\end{array}$ & 3 & $273.60 \pm 19.77$ & 7. 2 & 3 & $86.27 \pm$ & 6.52 & 7. 6 & 3 & 87. $33 \pm$ & 7. 91 & 9. 1 \\
\hline 「茅二」 & 2 & $276.15 \pm \quad 8.70$ & 3. 1 & 2 & 89. $35 \pm$ & 1. 20 & 1. 3 & 2 & $97.85 \pm$ & 1.06 & 1. 1 \\
\hline $\begin{array}{l}\text { A b ビーズ I } \\
\text { g E ‘栄研’ }\end{array}$ & 2 & $367.45 \pm 24.25$ & 6.6 & 2 & $112.65 \pm$ & 7. 14 & 6. 3 & 2 & 105. $15 \pm$ & 18. 60 & 17. 7 \\
\hline $\begin{array}{l}\text { Ig E・リア } \\
\text { ビーズ }\end{array}$ & 2 & 309. $35 \pm 17.47$ & 5. 6 & 2 & 89. $55 \pm$ & 2. 19 & 2. 4 & 2 & 88. $45 \pm$ & 7. 14 & 8. 1 \\
\hline $\operatorname{lMx}_{\text {タイナバック }} \underset{\mathrm{g}}{\mathrm{g} \mathrm{E}}$ & 2 & $327.55 \pm 1.77$ & 0.5 & 2 & 106. $51 \pm$ & 2. 95 & 2. 8 & 2 & 103. $22 \pm$ & 7. 47 & 7. 2 \\
\hline $\begin{array}{l}\text { ランリーム I } \\
\text { g E }\end{array}$ & 2 & $333.03 \pm 17.87$ & 5. 4 & 2 & $117.08 \pm$ & 1. 24 & 1. 1 & 2 & $120.24 \pm$ & 2. 31 & 1. 9 \\
\hline 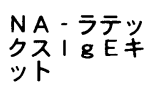 & 2 & $319.25 \pm 19.45$ & 6. 1 & 2 & $104.75 \pm$ & 2. 47 & 2. 4 & 2 & 103. $75 \pm$ & 1.06 & 1. 0 \\
\hline
\end{tabular}


（続き）

\begin{tabular}{|c|c|c|c|c|c|c|c|c|c|c|c|c|}
\hline \multirow{3}{*}{ キット名 } & \multirow{2}{*}{\multicolumn{4}{|c|}{$\operatorname{lgE}$}} & \multicolumn{5}{|c|}{ (単位: $\mid \mathrm{U} / \mathrm{m} \mathrm{l}$ ) } & \multirow{2}{*}{\multicolumn{3}{|c|}{ 試料 A-3 }} \\
\hline & & & & & & 試料 & $A-2$ & & & & & \\
\hline & $\mathbf{N}$ & Mean \pm & S. D. & C. V. & $\mathbf{N}$ & Mean 土 & S. D. & C. V. & $\mathbf{N}$ & Mean \pm & S. D. & C. $V$. \\
\hline $\begin{array}{l}\text { ケミルミAC } \\
S-1 \mathrm{gE} \text { (ケ } \\
\text { シタウルス) }\end{array}$ & 2 & $386.80 \pm$ & 20.08 & 5. 2 & 2 & 109. $50 \pm$ & 2. 12 & 1. 9 & 2 & $111.55 \pm$ & 2. 19 & 2. 0 \\
\hline $\begin{array}{l}\text { ルミパルス } \\
\mathrm{g} \text { E }\end{array}$ & 2 & $331.13 \pm$ & 11. 49 & 3. 5 & 2 & 101. $10 \pm$ & 5. 81 & 5. 7 & 2 & 100. $82 \pm$ & 6. 82 & 6. 8 \\
\hline $\begin{array}{l}\text { エンチムンテ } \\
\text { スト|gE }\end{array}$ & 1 & 317.98 & 0.00 & 0.0 & 1 & 111.06 & 0.00 & 0.0 & 1 & 107. 14 & 0.00 & 0.0 \\
\hline $\begin{array}{l}\text { イムノティク } \\
\text { ルスオート } \\
\text { gES }\end{array}$ & 1 & 340.00 & 0.00 & 0.0 & 1 & 103. 00 & 0.00 & 0.0 & 1 & 99.00 & 0.00 & 0.0 \\
\hline 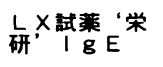 & 1 & 296. 00 & 0.00 & 0.0 & 1 & 91.00 & 0.00 & 0.0 & 1 & 88.00 & 0.00 & 0.0 \\
\hline 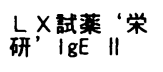 & 1 & 292. 00 & 0.00 & 0.0 & 1 & 93.00 & 0.00 & 0.0 & 1 & 80.00 & 0.00 & 0.0 \\
\hline 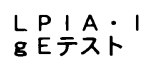 & 1 & 362.61 & 0.00 & 0.0 & 1 & 111.55 & 0.00 & 0.0 & 1 & 110.86 & 0.00 & 0.0 \\
\hline$N$-Latex I gE & 1 & 278.00 & 0.00 & 0.0 & 1 & 77.00 & 0.00 & 0.0 & 1 & 72. 80 & 0.00 & 0.0 \\
\hline
\end{tabular}




\begin{tabular}{|c|c|c|c|c|c|c|c|c|c|c|c|c|}
\hline \multirow{3}{*}{ キット名 } & \multicolumn{5}{|c|}{ シコキシン } & \multicolumn{4}{|c|}{ （単位： ng/ml) } & \multirow{3}{*}{\multicolumn{2}{|c|}{ 試料 A-3 }} & \multirow[b]{3}{*}{ C. V. } \\
\hline & \multicolumn{4}{|c|}{ 试料 A-1 } & \multicolumn{4}{|c|}{ 試料 A-2 } & \multirow[b]{2}{*}{$\mathbf{N}$} & & & \\
\hline & $\mathbf{N}$ & Mean \pm & S. D. & C. V. & $\mathbf{N}$ & Mean \pm & S. D. & C. V. & & Mean \pm & & \\
\hline アキシム ジゴ & 12 & $0.61 \pm$ & 0.08 & 14. 0 & 12 & 2. $05 \pm$ & 0.08 & 3. 9 & 12 & 3. $01 \pm$ & 0.12 & 3. 9 \\
\hline ナパック・NPT & 11 & $0.59 \pm$ & 0.06 & 10.5 & & & & & & & & \\
\hline $\begin{array}{l}\text { ケミルミAC } \\
\text { Sージコキシ }\end{array}$ & 12 & $0.62 \pm$ & 0.09 & 14. 1 & 12 & 2. $12 \pm$ & 0.11 & 5. 4 & 12 & 3. $17 \pm$ & 0.15 & 4. 6 \\
\hline シIㄴ & 11 & $0.64 \pm$ & 0.06 & 8. 8 & & & & & & & & \\
\hline $\begin{array}{l}\text { TDX-ジゴキシ } \\
\text { 」「アボット } \\
\text { 」ア }\end{array}$ & 6 & $0.59 \pm$ & 0.03 & 4. 5 & 6 & 2. $03 \pm$ & 0.12 & 5. 8 & 6 & 3. $18 \pm$ & 0.21 & 6.8 \\
\hline $\begin{array}{l}\text { エミット2000 } \\
\text { ジゴキシシア } \\
\text { ッセイ }\end{array}$ & 4 & $0.54 \pm$ & 0.07 & 12. 7 & 4 & 2. $09 \pm$ & 0.07 & 3. 6 & 4 & 3. $35 \pm$ & 0.11 & 3. 2 \\
\hline $\begin{array}{l}\text { アマレックスス } \\
\text { ジゴキシジ }\end{array}$ & 2 & $0.54 \pm$ & 0.03 & 5. 2 & 2 & 2. $07 \pm$ & 0.10 & 4. 8 & 2 & 3. $44 \pm$ & 0.04 & 1. 2 \\
\hline $\begin{array}{l}\text { セディアージゴ } \\
\text { キシシMAB }\end{array}$ & 2 & $0.85 \pm$ & 0.14 & 16. 6 & 2 & 2. $61 \pm$ & 0.06 & 2. 3 & 2 & 3. $94 \pm$ & 0.08 & 2. 2 \\
\hline $\begin{array}{l}\text { テクニコンイ } \\
\text { ジンジコキ } \\
\text { シンテト }\end{array}$ & 1 & 0.57 & 0.00 & . 0.0 & 1 & 2. 04 & 0.00 & 0.0 & 1 & 3. 23 & 0.00 & 0.0 \\
\hline $\begin{array}{l}\text { シンククロンシ } \\
\text { ステ䨿莯 } \\
\text { ジキ }\end{array}$ & 1 & 1. 00 & 0.00 & 0.0 & 1 & 2. 70 & 0.00 & 0.0 & 1 & 4. 10 & 0.00 & 0.0 \\
\hline $\begin{array}{l}\text { acaパックジゴ } \\
\text { キシン }\end{array}$ & 1 & 0.64 & 0.00 & 0.0 & 1 & 2. 11 & 0.00 & 0.0 & 1 & 3. 47 & 0.00 & 0.0 \\
\hline $\begin{array}{l}\text { IMx ジゴキシ } \\
\text { ッ゙多イナバ } \\
\text { ック・NPT }\end{array}$ & 1 & 0.52 & 0.00 & 0.0 & 1 & 2. 12 & 0.00 & 0.0 & 1 & 3. 12 & 0.00 & 0.0 \\
\hline $\begin{array}{l}\text { LP IA A ジ } \\
\text { ゴキシンテス } \\
\text { ト }\end{array}$ & 1 & 0.56 & 0.00 & 0.0 & 1 & 2. 10 & 0.00 & 0.0 & 1 & 3. 41 & 0.00 & 0.0 \\
\hline $\begin{array}{l}\text { ケミルミAC } \\
\text { S-ジゴキジン } \\
\text { 川 (ケシタウル }\end{array}$ & 1 & 0.65 & 0.00 & 0.0 & 1 & 2. 32 & 0.00 & 0.0 & 1 & 3. 51 & 0.00 & 0.0 \\
\hline
\end{tabular}




\section{AFP \\ (単位: $\mathrm{ng} / \mathrm{ml}$ )}

キット名

试料 A-1

$\mathbf{N}$ Mean \pm S. D. $\quad$ C. V. $\mathbf{N}$ Mean \pm S. D. C. V. $\mathbf{N}$ Mean \pm S. D. C. V.

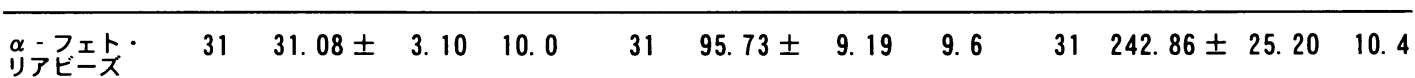

\begin{tabular}{lllllllllll}
29 & $30.51 \pm$ & 2.18 & 7.2 & 29 & $94.15 \pm$ & 7.08 & 7.5 & 29 & $238.97 \pm 20.86$ & 8.7 \\
\hline
\end{tabular}

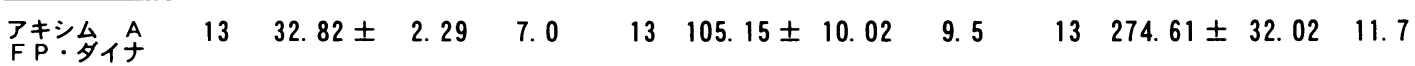

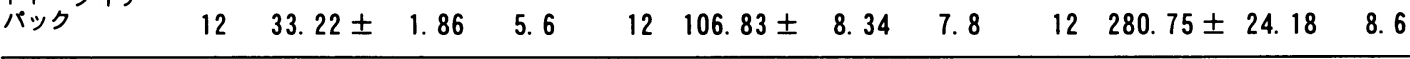

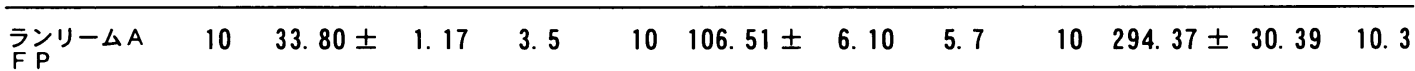

$9 \quad 33.53 \pm \quad 0.85 \quad 2.5$

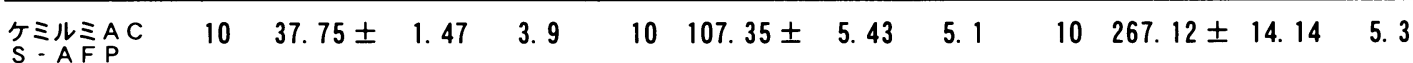

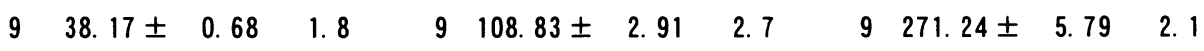

\begin{tabular}{lllllllllll}
\hline ルミバルスA & 8 & $33.78 \pm$ & 3.08 & 9.1 & 8 & $108.36 \pm 11.51$ & 10.6 & 8 & $292.08 \pm 29.73$ & 10.2
\end{tabular}

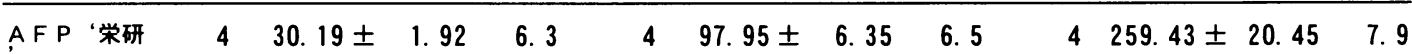

\begin{tabular}{|c|c|c|c|c|c|c|c|c|c|c|}
\hline $\begin{array}{l}\text { A b ビー爻 } A \\
F \text { P “研” }\end{array}$ & 4 & $27.89 \pm$ & 4. 33 & 15.5 & 4 & $85.43 \pm$ & 6.71 & 7. 9 & 4 & $254.80 \pm 32.46$ \\
\hline エルピアエー & 4 & $37.69 \pm$ & 2. 89 & 7. 7 & 4 & $111.92 \pm$ & 7. 85 & 7. 0 & 4 & $290.18 \pm 11.89$ \\
\hline
\end{tabular}

\begin{tabular}{|c|c|c|c|c|c|c|c|c|c|c|c|c|}
\hline $\begin{array}{l}\text { エンチムンテ } \\
\text { ストAFP } \\
C\end{array}$ & 3 & 29. $36 \pm$ & 3. 07 & 10. 5 & 3 & 86. $65 \pm$ & 6.27 & 7. 2 & 3 & 234. $28 \pm$ & 28. 39 & 12. 1 \\
\hline
\end{tabular}

\begin{tabular}{|c|c|c|c|c|c|c|c|c|c|c|c|c|}
\hline $\begin{array}{l}\text { グラオザイム } \\
\text { [New }] \text { AF P }\end{array}$ & 3 & 30. $52 \pm$ & 1. 97 & 6. 5 & 3 & $91.18 \pm$ & 8. 00 & 8. 8 & 3 & 244. $13 \pm$ & 26. 18 & 10.7 \\
\hline $\begin{array}{l}\text { スパック-S } \\
\alpha-フ ェ ト \\
\text { キット }\end{array}$ & 2 & 38. $82 \pm$ & 2. 43 & 6. 3 & 2 & $108.08 \pm$ & 1. 30 & 1. 2 & 2 & 259. $36 \pm$ & 24. 55 & 9. 5 \\
\hline $\begin{array}{l}\alpha \text {-フェトキ } \\
\text { 光ト「第一」 }\end{array}$ & 2 & 35. $70 \pm$ & 0.99 & 2. 8 & 2 & 98. $15 \pm$ & 0.63 & 0.6 & 2 & $261.33 \pm$ & 18. 85 & 7. 2 \\
\hline $\begin{array}{l}\text { リアグノスト } \\
\text { CAF P }\end{array}$ & 2 & 26. $35 \pm$ & 0.92 & 3. 5 & 2 & $66.65 \pm$ & 2. 33 & 3. 5 & 2 & 183. $50 \pm$ & 30.41 & 16. 6 \\
\hline $\begin{array}{l}\text { グラオザイム } \\
\text { [N] AF P ( } \\
\text { P) }\end{array}$ & 2 & 30. $50 \pm$ & 0.71 & 2. 3 & 2 & 99. $45 \pm$ & 4. 31 & 4. 3 & 2 & $256.80 \pm$ & 6.65 & 2. 6 \\
\hline
\end{tabular}

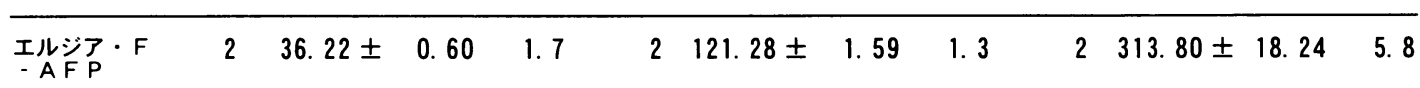




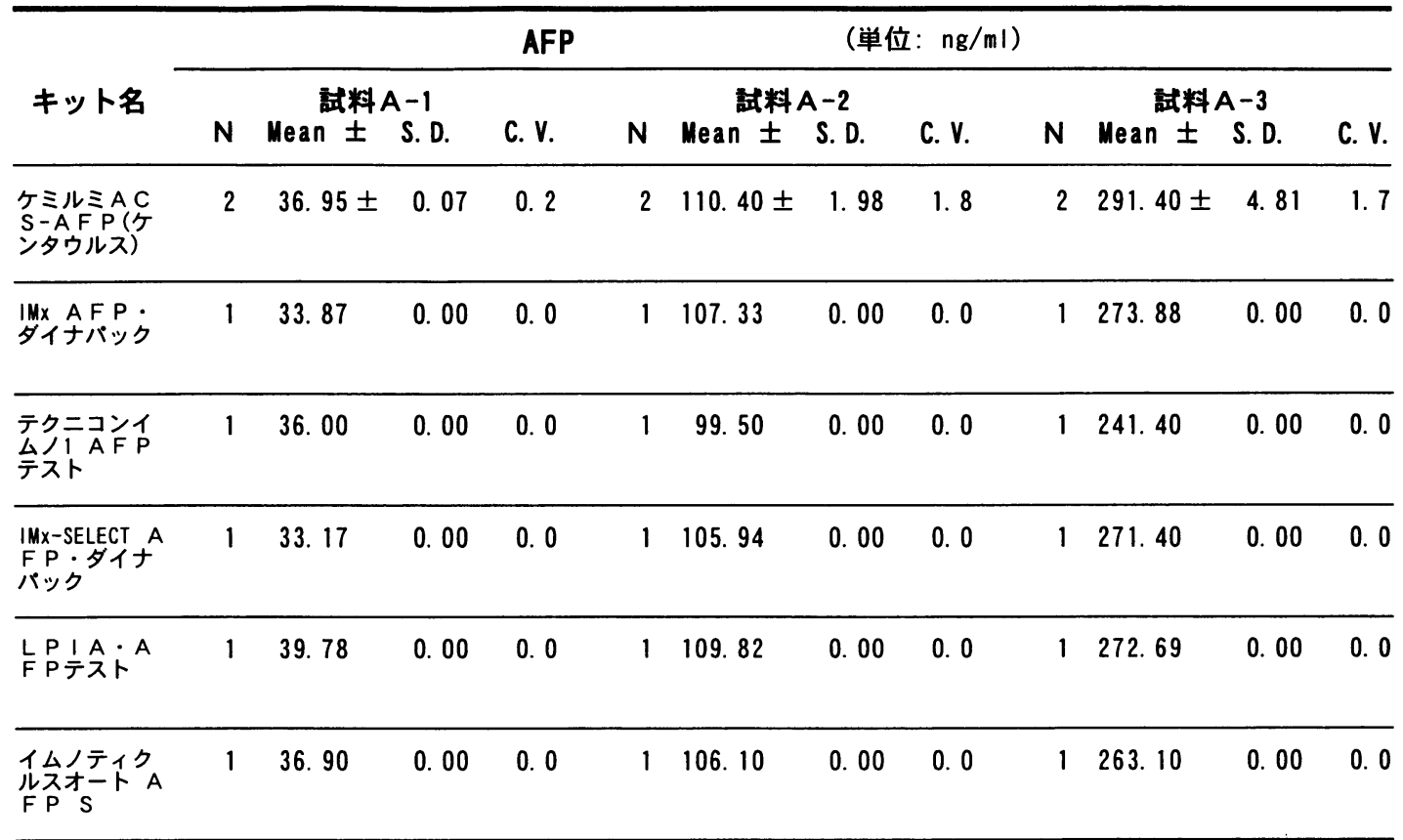




\begin{tabular}{|c|c|c|c|c|c|c|c|c|}
\hline \multirow{3}{*}{ キット名 } & \multicolumn{5}{|c|}{ CEA } & \multicolumn{3}{|c|}{ (単位： $\mathrm{ng} / \mathrm{ml}$ ) } \\
\hline & & 試料 & $3-1$ & & & 侙料 $\mathrm{E}$ & $B-2$ & \\
\hline & $\mathbf{N}$ & Mean \pm & S. D. & C. V. & $\mathbf{N}$ & Mean \pm & S. D. & C. V. \\
\hline \multirow{2}{*}{$\begin{array}{l}\text { CEA・リア } \\
\text { ビース }\end{array}$} & 29 & $0.75 \pm$ & 0.14 & 19. 0 & 33 & 4. $85 \pm$ & 0.58 & 12. 0 \\
\hline & 28 & $0.73 \pm$ & 0.13 & 17. 2 & 30 & 4. $79 \pm$ & 0.37 & 7. 7 \\
\hline \multirow{2}{*}{ C_E } & 12 & $1.61 \pm$ & 0.19 & 11.7 & 12 & 14. $47 \pm$ & 1. 22 & 8. 4 \\
\hline & 11 & 1. $57 \pm$ & 0.15 & 9.4 & 11 & 14. $24 \pm$ & 0.97 & 6. 8 \\
\hline $\begin{array}{l}\text { アキシム C } \\
\text { EA・ダィナ } \\
\text { パック }\end{array}$ & 12 & 3. $48 \pm$ & 0.26 & 7. 5 & 12 & $33.04 \pm$ & 1. 76 & 5. 3 \\
\hline \multirow{2}{*}{$\begin{array}{l}\text { ケミルミAC } \\
S \text { - CEA }\end{array}$} & 10 & 2. $27 \pm$ & 0.20 & 8. 7 & 10 & 19. $82 \pm$ & 1. 49 & 7. 5 \\
\hline & 9 & 2. $32 \pm$ & 0.12 & 5. 0 & & & & \\
\hline \multirow{2}{*}{ ランンリームC } & 9 & 4. $81 \pm$ & 1. 41 & 29. 4 & 9 & 46. $46 \pm$ & 13. 63 & 29. 3 \\
\hline & 8 & 5. $24 \pm$ & 0.64 & 12. 3 & 8 & $50.61 \pm$ & 5. 98 & 11.8 \\
\hline $\begin{array}{l}\text { ルミパルスC } \\
\mathrm{E} \text { A-N }\end{array}$ & 7 & 3. $26 \pm$ & 0.10 & 3. 0 & 7 & 32. $64 \pm$ & 1. 18 & 3. 6 \\
\hline $\begin{array}{l}\text { Eテスト「 } \\
\text { TOSOH」 \|C E } \\
\text { A }\end{array}$ & 4 & 8. $20 \pm$ & 0.49 & 6.0 & 4 & 83. $55 \pm$ & 3. 02 & 3. 6 \\
\hline 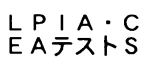 & 4 & 4. $00 \pm$ & 0.41 & 10. 4 & 4 & 22. $42 \pm$ & 1. 19 & 5. 3 \\
\hline $\begin{array}{l}\text { グラオザイム } \\
\text { [New] CE A }\end{array}$ & 3 & 2. $05 \pm$ & 0.22 & 10. 6 & 3 & 18. $15 \pm$ & 0.79 & 4. 3 \\
\hline $\begin{array}{l}\text { ケミルミAC } \\
\text { S-CEA (ケ } \\
\text { シタウルス) }\end{array}$ & 3 & 2. $19 \pm$ & 0.19 & 8. 5 & 3 & $20.91 \pm$ & 0.69 & 3. 3 \\
\hline C E A “栄研 & 2 & 1. $09 \pm$ & 0.06 & 5. 2 & 2 & 7. $73 \pm$ & 2. 57 & 33. 3 \\
\hline 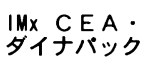 & 2 & 3. $57 \pm$ & 0.32 & 8. 9 & 2 & 33. $30 \pm$ & 0.14 & 0.4 \\
\hline エンチムンテテ & 2 & 4. $79 \pm$ & 0.27 & 5. 6 & 2 & 46. $14 \pm$ & 2. 46 & 5. 3 \\
\hline $\begin{array}{l}\text { テクニコンイ } \\
\text { ムノ人 CE A } \\
\text { テスト }\end{array}$ & 2 & 2. $00 \pm$ & 0.14 & 7. 1 & 2 & $20.25 \pm$ & 0.49 & 2. 4 \\
\hline $\begin{array}{l}\text { ボールエルザ } \\
\text { ツСEA・キ } \\
\text { ツト }\end{array}$ & 1 & 3. 21 & 0.00 & 0.0 & 1 & 24. 30 & 0.00 & 0.0 \\
\hline $\begin{array}{l}\text { IMx-SELECT C } \\
\text { EA A タイナ } \\
\text { パック }\end{array}$ & 1 & 3. 60 & 0.00 & 0.0 & 1 & 33. 10 & 0.00 & 0.0 \\
\hline
\end{tabular}




\begin{tabular}{|c|c|c|c|c|c|c|c|c|}
\hline \multirow{3}{*}{ キット名 } & \multicolumn{5}{|c|}{ CEA } & \multicolumn{3}{|c|}{ (単位：ng/ml) } \\
\hline & \multicolumn{4}{|c|}{ 試料 B -1 } & \multicolumn{4}{|c|}{ 試料 B -2 } \\
\hline & $\mathbf{N}$ & Mean \pm & S. D. & C. V. & $\mathbf{N}$ & Mean \pm & S. D. & C. $V$. \\
\hline $\begin{array}{l}\text { コバスコアC } \\
E A \| E \text { I }\end{array}$ & 1 & 4. 00 & 0.00 & 0.0 & 1 & 36.60 & 0.00 & 0.0 \\
\hline $\begin{array}{l}\text { エンチムンテ } \\
\text { ストCEA II }\end{array}$ & 1 & 4. 96 & 0.00 & 0.0 & 1 & 45.41 & 0.00 & 0.0 \\
\hline $\begin{array}{l}\text { エルジア・F } \\
\text { - CEA }\end{array}$ & 1 & 1. 40 & 0.00 & 0.0 & 1 & 12. 50 & 0.00 & 0.0 \\
\hline $\begin{array}{l}\text { ルミノマスタ } \\
\text {-「CEA」 }\end{array}$ & 1 & 3. 20 & 0.00 & 0.0 & 1 & 26. 30 & 0.00 & 0.0 \\
\hline
\end{tabular}

\begin{tabular}{|c|c|c|c|c|c|c|c|c|}
\hline \multirow{3}{*}{ キット名 } & \multicolumn{5}{|c|}{ TPA } & \multicolumn{3}{|c|}{ (単位：U/I) } \\
\hline & \multicolumn{4}{|c|}{ 試料 B-1 } & \multicolumn{4}{|c|}{ 試料 B - 2} \\
\hline & $\mathbf{N}$ & Mean \pm & S. D. & C. V. & $\mathbf{N}$ & Mean \pm & S. D. & C. V. \\
\hline \multirow{2}{*}{$\begin{array}{l}\text { プロリフィゲ. } \\
\text { シัTPA-M“" } \\
\text { 第一” }\end{array}$} & 34 & $61.02 \pm$ & 10. 36 & 17.0 & \multirow[t]{2}{*}{34} & \multirow[t]{2}{*}{$0.00 \pm$} & \multirow[t]{2}{*}{0.00} & \multirow[t]{2}{*}{0.0} \\
\hline & 32 & $62.71 \pm$ & 7. 94 & 12. 7 & & & & \\
\hline $\begin{array}{l}\text { TPSA I } \\
\text { RMA M } \\
\text { PXジ』 }\end{array}$ & 5 & $98.74 \pm$ & 11.73 & 11.9 & 5 & $0.00 \pm$ & 0.00 & 0.0 \\
\hline $\begin{array}{l}\text { TPSAEL } \\
\text { ISAキット } \\
\text { TXシ』 }\end{array}$ & 1 & 107.90 & 0.00 & 0.0 & 1 & 0.00 & 0.00 & 0.0 \\
\hline
\end{tabular}




\begin{tabular}{|c|c|c|c|c|c|c|c|c|}
\hline \multirow{3}{*}{ キット名 } & \multicolumn{5}{|c|}{ CA125 } & \multicolumn{3}{|c|}{ （単位：U/mI） } \\
\hline & & 调料 & & & & 試料 E & $3-2$ & \\
\hline & $\mathbf{N}$ & Mean \pm & S. D. & C. V. & $\mathbf{N}$ & Mean \pm & S. D. & C. V. \\
\hline \multirow{2}{*}{$\begin{array}{l}\text { セントコアC } \\
\text { A } 125 \text { 出 I } \\
\text { RMAキット }\end{array}$} & 37 & 34. $40 \pm$ & 1. 74 & 5. 1 & 37 & 112. $60 \pm$ & 5. 37 & 4. 8 \\
\hline & 36 & 34. $52 \pm$ & 1.61 & 4. 7 & 35 & 112. $60 \pm$ & 4. 63 & 4. 1 \\
\hline \multirow{2}{*}{$\begin{array}{l}\text { アキシム } \mathrm{C} \\
\mathrm{A} 125.8 \\
\text { イナパック }\end{array}$} & 12 & 38. $40 \pm$ & 3. 92 & 10. 2 & 12 & $135.87 \pm$ & 8. 76 & 6. 4 \\
\hline & 11 & 37. $55 \pm$ & 2. 70 & 7. 2 & 11 & 134. $22 \pm$ & 6. 96 & 5. 2 \\
\hline $\begin{array}{l}\text { ボールエルザ } \\
\dot{0} \mathrm{CA} 125 \\
\text { I・キット }\end{array}$ & 10 & 42. $26 \pm$ & 3. 27 & 7. 7 & 10 & $137.25 \pm$ & 9. 43 & 6. 9 \\
\hline $\begin{array}{l}\text { ルミバルスC } \\
\mathrm{A} 125 \|\end{array}$ & 10 & 26. $41 \pm$ & 1. 81 & 6. 9 & 10 & $92.58 \pm$ & 6.85 & 7. 4 \\
\hline $\begin{array}{l}\text { エンチムンテ } \\
\text { スト } \\
5 \text { II }\end{array}$ & 3 & $30.60 \pm$ & 0.72 & 2. 3 & 3 & $105.86 \pm$ & 4. 07 & 3. 8 \\
\hline 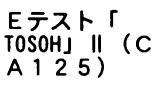 & 3 & 41. $60 \pm$ & 2. 50 & 6. 0 & 3 & 145. $30 \pm$ & 4. 95 & 3. 4 \\
\hline $\begin{array}{l}\text { コバスコア式 } \\
\text { 菲CA } 1255 \\
\text { II-E | A }\end{array}$ & 3 & 52. $77 \pm$ & 4. 52 & 8. 6 & 3 & 192. $30 \pm$ & 5. 48 & 2. 9 \\
\hline 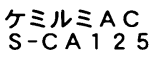 & 3 & 45. $67 \pm$ & 2. 31 & 5. 1 & 3 & 176. $43 \pm$ & 14. 03 & 8. 0 \\
\hline $\begin{array}{l}\text { エルザ・CA } \\
125 \| \text { ・ } \\
\text { ット }\end{array}$ & 2 & $30.55 \pm$ & 2. 33 & 7. 6 & 2 & $107.80 \pm$ & 1. 13 & 1. 0 \\
\hline $\begin{array}{l}14 / 1 \text { cA } \\
125 \| テ ス \\
\text { ト「バイエル」 }\end{array}$ & 2 & 28. $45 \pm$ & 0.78 & 2. 7 & 2 & 102. $40 \pm$ & 0. 56 & 0.6 \\
\hline ランリームC & 2 & 33. $50 \pm$ & 0.71 & 2. 1 & 2 & 117. $40 \pm$ & 11.88 & 10. 1 \\
\hline $\begin{array}{l}\text { ケミルミAC } \\
\text { S-CA } 1225 \\
\text { (ケンタウルス }\end{array}$ & 2 & 52. $10 \pm$ & 2. 97 & 5. 7 & 2 & $207.25 \pm$ & 5. 30 & 2. 6 \\
\hline $\begin{array}{l}\text { グラオザイム } \\
\text { [N]CA } 1225\end{array}$ & 1 & 27.00 & 0.00 & 0.0 & 1 & 101.00 & 0.00 & 0.0 \\
\hline $\begin{array}{l}\text { IMx CA } 12 \\
5 \text { タタイナハ } \\
\text { ック }\end{array}$ & 1 & 38. 14 & 0.00 & 0.0 & 1 & 142. 21 & 0.00 & 0.0 \\
\hline
\end{tabular}




\begin{tabular}{|c|c|c|c|c|c|c|c|c|}
\hline \multirow{3}{*}{ キット名 } & \multicolumn{5}{|c|}{ CA19-9 } & \multicolumn{3}{|c|}{ （単位：U/mI） } \\
\hline & & 試料 & $3-1$ & & & 試料 & $3-2$ & \\
\hline & $\mathbf{N}$ & Mean \pm & S. D. & C. V. & $\mathbf{N}$ & Mean \pm & S. D. & C. V. \\
\hline \multirow{2}{*}{$\begin{array}{l}\text { セントコアC } \\
\text { A } 19-9 R \\
1 \text { Aキット }\end{array}$} & 41 & $11.60 \pm$ & 2. 11 & 18. 2 & 41 & $51.70 \pm$ & 7. 23 & 14. 0 \\
\hline & 39 & $11.29 \pm$ & 1. 63 & 14. 4 & 39 & $50.58 \pm$ & 5. 32 & 10. 5 \\
\hline \multirow{2}{*}{$\begin{array}{l}\text { アキシム C } \\
\text { A199-9 } \\
\text { タイナバック }\end{array}$} & 10 & 9. $81 \pm$ & 1. 55 & 15. 8 & 10 & 52. $24 \pm$ & 3. 61 & 6. 9 \\
\hline & 9 & 9. $45 \pm$ & 1. 13 & 12. 0 & & & & \\
\hline $\begin{array}{l}\text { ケミルミA C } \\
\text { S-CA } 19- \\
9\end{array}$ & 10 & 14. $22 \pm$ & 1. 52 & 10.7 & 10 & 52. $51 \pm$ & 1. 83 & 3. 5 \\
\hline 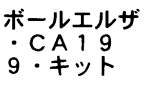 & 6 & 14. $33 \pm$ & 0.58 & 4. 1 & 6 & 64. $96 \pm$ & 3. 27 & 5. 0 \\
\hline $\begin{array}{l}\text { ルミパルスC } \\
\text { A } 19-9\end{array}$ & 6 & 12. $02 \pm$ & 1. 07 & 8. 9 & 6 & 54. $08 \pm$ & 4. 03 & 7. 5 \\
\hline $\begin{array}{l}\text { ルミパルスC } \\
\mathrm{A} 19-9 \mathrm{~N}\end{array}$ & 5 & 11. $48 \pm$ & 0.62 & 5. 4 & 5 & 50. $93 \pm$ & 1. 94 & 3. 8 \\
\hline $\begin{array}{l}\text { ランリーム C } \\
\text { A } 199-9\end{array}$ & 4 & 11. $45 \pm$ & 1. 39 & 12. 1 & 4 & 45. $28 \pm$ & 3. 56 & 7. 9 \\
\hline $\begin{array}{l}\text { エルザ・CA } \\
19-9 ・ \neq \\
\text { ット }\end{array}$ & 3 & 9. $63 \pm$ & 0.95 & 9. 9 & 3 & $40.20 \pm$ & 1. 65 & 4. 1 \\
\hline $\begin{array}{l}\text { Eテ자 } \\
\text { TOSOHJ " } \\
\text { A } 190-9)\end{array}$ & 3 & 10. $30 \pm$ & 0.89 & 8. 6 & 3 & 37. $40 \pm$ & 1. 15 & 3. 1 \\
\hline $\begin{array}{l}\text { エンチムンテ } \\
\text { ストCA } 199 \\
-9 \text { E C }\end{array}$ & 3 & 8. $02 \pm$ & 0.88 & 10. 9 & 3 & $57.17 \pm$ & 2. 47 & 4. 3 \\
\hline $\begin{array}{l}\text { ケミルミAC } \\
\text { S-CA } 19- \\
9 \text { (ケンタウル }\end{array}$ & 3 & 15. $53 \pm$ & 1. 29 & 8. 3 & 3 & 57. $19 \pm$ & 3. 54 & 6. 2 \\
\hline $\begin{array}{l}\text { IMx CA } 19- \\
9 \text { タイナパ } \\
\text { ック }\end{array}$ & 2 & 9. $86 \pm$ & 0.33 & 3. 4 & 2 & $55.22 \pm$ & 2. 50 & 4. 5 \\
\hline $\begin{array}{l}\text { グラオザイム } \\
\text { [New] CA } 1 \\
9-9\end{array}$ & 2 & $6.65 \pm$ & 0.49 & 7. 4 & 2 & $28.65 \pm$ & 2. 05 & 7. 2 \\
\hline $\begin{array}{l}\text { イムノCA } \\
19-9 \text { テスト } \\
\text { 「パイエル」 }\end{array}$ & 2 & 10. $40 \pm$ & 0.57 & 5. 4 & 2 & $69.30 \pm$ & 3. 25 & 4. 7 \\
\hline $\begin{array}{l}L P \mid A \cdot C \\
A 19-9 \text { \% } \\
\text { スト }\end{array}$ & 2 & 22. $78 \pm$ & 0.21 & 0.9 & 2 & 43. $97 \pm$ & 1. 44 & 3. 3 \\
\hline $\begin{array}{l}\text { グラオザイム } \\
\text { [N] CA } 1 \\
9-9(P)\end{array}$ & 1 & 9. 00 & 0.00 & 0.0 & 1 & 35.50 & 0.00 & 0.0 \\
\hline
\end{tabular}


（続き）

\begin{tabular}{|c|c|c|c|c|c|c|c|c|}
\hline \multirow{3}{*}{ キット名 } & \multicolumn{5}{|c|}{ CA19-9 } & \multicolumn{3}{|c|}{ (単位: $U / m \mid$ ) } \\
\hline & & 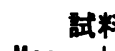 & $B-1$ & & & 試䊀 & $B-2$ & \\
\hline & $\mathbf{N}$ & Mean \pm & S. D. & C. V. & $\mathbf{N}$ & Mean \pm & S. D. & C. $v$. \\
\hline $\begin{array}{l}\text { IMX-SELECT C } \\
\text { A19 } 99.9 \\
\text { タイナバック }\end{array}$ & 1 & 9. 84 & 0.00 & 0.0 & 1 & 56.83 & 0.00 & 0.0 \\
\hline
\end{tabular}

\begin{tabular}{|c|c|c|c|c|c|c|c|c|}
\hline \multirow{3}{*}{ キット名 } & \multicolumn{5}{|c|}{ CA15-3 } & \multicolumn{3}{|c|}{ （単位：U/mI） } \\
\hline & & 試料 & $3-1$ & & & 試料 & $3-2$ & \\
\hline & $\mathbf{N}$ & Mean 士 & S. D. & C. V. & $\mathbf{N}$ & Mean 土 & S. D. & C. V. \\
\hline \multirow{2}{*}{$\begin{array}{l}\text { セントコアC } \\
\text { A } 15-3 R \\
\text { IAキット }\end{array}$} & \multirow[t]{2}{*}{26} & \multirow[t]{2}{*}{ 13. $31 \pm$} & \multirow[t]{2}{*}{ 1. 35} & \multirow[t]{2}{*}{ 10. 2} & 26 & 34. $99 \pm$ & 2. 91 & 8. 3 \\
\hline & & & & & 24 & 34. $89 \pm$ & 2. 15 & 6. 2 \\
\hline $\begin{array}{l}\text { ボールエルザ } \\
\text { 3손 } \\
3 \text { ・キット }\end{array}$ & 6 & 14. $73 \pm$ & 1. 33 & 9. 0 & 6 & $37.63 \pm$ & 5. 99 & 15. 9 \\
\hline $\begin{array}{l}\text { アキシム C } \\
\text { A } 15-3 . \text { 多 } \\
\text { イナパック }\end{array}$ & 4 & 12. $92 \pm$ & 0.54 & 4. 2 & 4 & 41. $47 \pm$ & 3. 25 & 7. 8 \\
\hline $\begin{array}{l}\text { エンチムンテ } \\
\text { ストCA } 115 \\
-3 \text { E C }\end{array}$ & 4 & 11. $56 \pm$ & 0.50 & 4. 4 & 4 & 37. $55 \pm$ & 0.30 & 0.8 \\
\hline $\begin{array}{l}\text { ルミパルスC } \\
\text { A } 15-3\end{array}$ & 4 & 15. $48 \pm$ & 2. 74 & 17.7 & 4 & 47. $25 \pm$ & 5. 93 & 12. 6 \\
\hline $\begin{array}{l}\text { ケミルミA C } \\
S=C A 15- \\
3\end{array}$ & 4 & 10. $63 \pm$ & 2. 29 & 21.6 & 4 & 39. $05 \pm$ & 2. 41 & 6. 2 \\
\hline $\begin{array}{l}\text { エルザ・CA } \\
15-3 ・ キ ~ \\
\text { ット\| }\end{array}$ & 2 & 12. $11 \pm$ & 0.27 & 2. 2 & 2 & 32. $94 \pm$ & 3. 62 & 11.0 \\
\hline $\begin{array}{l}\text { イム1CA } \\
15-3 テ ス ト \\
\text { 「パイエ」 }\end{array}$ & 2 & 12. $10 \pm$ & 0.85 & 7. 0 & 2 & $37.25 \pm$ & 2. 05 & 5. 5 \\
\hline 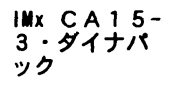 & 1 & 12. 50 & 0.00 & 0.0 & 1 & 42. 40 & 0.00 & 0.0 \\
\hline $\begin{array}{l}コ ハ ゚ ス コ ア C \\
A 15-3-E \\
\text { IA }\end{array}$ & 1 & 16.00 & 0.00 & 0.0 & 1 & 43. 00 & 0.00 & 0.0 \\
\hline
\end{tabular}




\begin{tabular}{|c|c|c|c|c|c|c|c|c|}
\hline \multirow{3}{*}{ キット名 } & \multicolumn{5}{|c|}{ PAP } & \multicolumn{3}{|c|}{ （単位：ng/ml) } \\
\hline & & 武料 & $3-1$ & & & 試料 B & $3-2$ & \\
\hline & $\mathbf{N}$ & Mean \pm & S. D. & C. V. & $\mathbf{N}$ & Mean \pm & S. D. & C. V. \\
\hline \multirow[t]{2}{*}{ P A P “栄研 } & 11 & 22. $47 \pm$ & 1. 55 & 6. 9 & 10 & $217.22 \pm$ & 20.06 & 9. 2 \\
\hline & 10 & 22. $15 \pm$ & 1. 18 & 5. 3 & 9 & $221.87 \pm$ & 14. 48 & 6. 5 \\
\hline \multirow{2}{*}{$\begin{array}{l}\text { ボールエルザ } \\
\text { ツト } \\
\text { ツト・キ }\end{array}$} & \multirow[t]{2}{*}{8} & \multirow[t]{2}{*}{ 33. $94 \pm$} & \multirow[t]{2}{*}{ 1. 31} & \multirow[t]{2}{*}{ 3. 9} & 8 & \multicolumn{2}{|c|}{ 328. $54 \pm 104.29$} & 31.7 \\
\hline & & & & & 7 & $360.76 \pm$ & 54. 78 & 15. 2 \\
\hline 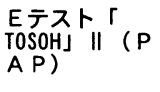 & 5 & 24. $52 \pm$ & 1. 16 & 4. 7 & 5 & 263. $78 \pm$ & 14. 52 & 5. 5 \\
\hline $\begin{array}{l}\text { ガンマーダフ } \\
\text { PAP }\end{array}$ & 3 & 19. $55 \pm$ & 1. 48 & 7. 5 & 2 & $173.70 \pm$ & 25.03 & 14. 4 \\
\hline 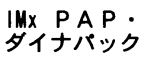 & 3 & 26. $97 \pm$ & 0.48 & 1. 8 & 3 & 205. $43 \pm$ & 58.87 & 28. 7 \\
\hline 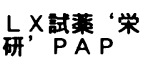 & 2 & $15.02 \pm$ & 0.04 & 0.2 & 1 & 189.00 & 0.00 & 0.0 \\
\hline $\begin{array}{l}\text { デルフィアP } \\
A P\end{array}$ & 2 & $16.88 \pm$ & 0.25 & 1. 5 & 2 & $200.25 \pm$ & 0.35 & 0.2 \\
\hline DPC・イム & 2 & 12. $75 \pm$ & 2. 19 & 17. 2 & 2 & 116. $50 \pm$ & 1. 41 & 1. 2 \\
\hline $\begin{array}{l}D P C \cdot P A \\
P \text { IRMA }\end{array}$ & 1 & 31.00 & 0.00 & 0.0 & 0 & 0.00 & 0.00 & 0.0 \\
\hline $\begin{array}{l}\text { コスメディ. } \\
\text { F PAP }\end{array}$ & 1 & 28. 40 & 0.00 & 0.0 & 1 & 313. 20 & 0.00 & 0.0 \\
\hline
\end{tabular}




\begin{tabular}{|c|c|c|c|c|c|c|c|c|}
\hline \multirow{3}{*}{ キット名 } & \multicolumn{5}{|c|}{ PA (PSA) } & \multicolumn{3}{|c|}{ (単位: ng/mI) } \\
\hline & \multicolumn{4}{|c|}{ 試料 B-1 } & \multicolumn{4}{|c|}{ 試料 B-2 } \\
\hline & $\mathbf{N}$ & Mean \pm & S. D. & C. v. & $\mathbf{N}$ & Mean \pm & S. D. & C. V. \\
\hline \multirow{2}{*}{ タンデムPS } & \multirow[t]{2}{*}{13} & \multirow[t]{2}{*}{ 5. $53 \pm$} & \multirow[t]{2}{*}{0.31} & \multirow[t]{2}{*}{ 5. 6} & 13 & 58. $56 \pm$ & 2. 28 & 3. 9 \\
\hline & & & & & 12 & 58. $95 \pm$ & 1. 88 & 3. 2 \\
\hline \multirow{2}{*}{$\begin{array}{l}\text { アキシシムPS } \\
\text { ^:タイナバ } \\
\text { ック }\end{array}$} & 10 & 4. $46 \pm$ & 0.39 & 8.7 & 10 & $50.62 \pm$ & 6. 36 & 12. 6 \\
\hline & 9 & 4. $56 \pm$ & 0.26 & 5. 6 & 9 & 52. $06 \pm$ & 4. 72 & 9. 1 \\
\hline \multirow{2}{*}{ 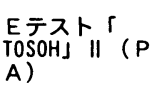 } & \multirow[t]{2}{*}{9} & \multirow{2}{*}{ 5. $38 \pm$} & \multirow[t]{2}{*}{0.20} & \multirow[t]{2}{*}{ 3. 7} & 9 & 58. $61 \pm$ & 3. 34 & 5. 7 \\
\hline & & & & & 8 & $57.74 \pm$ & 2. 21 & 3. 8 \\
\hline $\begin{array}{l}\text { A b ビー栥研? } \\
\text { S A }\end{array}$ & 6 & 4. $99 \pm$ & 0.31 & 6.2 & 6 & $69.72 \pm$ & 6. 28 & 9. 0 \\
\hline $\begin{array}{l}\text { ケミルミAC } \\
\text { S:P SAA }\end{array}$ & 5 & 12. $78 \pm$ & 0.72 & 5. 6 & 5 & 148. $78 \pm$ & 20.69 & 13. 9 \\
\hline $\begin{array}{l}\text { ケミルミAC } \\
S \text { PSA2 }\end{array}$ & 4 & 13. $08 \pm$ & 1.11 & 8.5 & 4 & 142. $60 \pm$ & 15.68 & 11.0 \\
\hline $\begin{array}{l}\text { アキシムム P } \\
\text { A:タイイパ } \\
\text { ック }\end{array}$ & 3 & 7. $56 \pm$ & 2. 28 & 30.1 & 3 & 86. $27 \pm$ & 25.09 & 29. 1 \\
\hline $\begin{array}{l}\text { デルフィアP } \\
\text { SA }\end{array}$ & 3 & 7. $15 \pm$ & 0.57 & 7. 9 & 3 & $80.52 \pm$ & 8. 41 & 10.5 \\
\hline $\begin{array}{l}\text { ルミパルスP } \\
\text { SA }\end{array}$ & 3 & 7. $92 \pm$ & 0.69 & 8.7 & 3 & 94. $27 \pm$ & 9. 00 & 9. 5 \\
\hline $\begin{array}{l}\text { ケミルミAC } \\
\text { S-PSA(ケ } \\
\text { シタウルス }\end{array}$ & 3 & $11.73 \pm$ & 0.66 & 5.6 & 3 & 144. $88 \pm$ & 7. 93 & 5. 5 \\
\hline $\begin{array}{l}\text { DPC・イA } \\
\text { ライスPSA }\end{array}$ & 3 & 6. $10 \pm$ & 0.40 & 6.6 & 3 & 77. $60 \pm$ & 3. 04 & 3. 9 \\
\hline $\begin{array}{l}\text { DPC・イム } \\
\text { ライスXHS } \\
\text { PSA }\end{array}$ & 3 & 5. $45 \pm$ & 0.72 & 13.3 & 3 & 75. $60 \pm$ & 3. 21 & 4. 2 \\
\hline リアコート・ & 2 & 4. $74 \pm$ & 2. 45 & 51.6 & 2 & $67.64 \pm$ & 4. 16 & 6. 1 \\
\hline $\begin{array}{l}\text { クラオザイム } \\
\text { [N] PAA }\end{array}$ & 2 & 8. $10 \pm$ & 1.41 & 17.5 & 2 & $89.40 \pm$ & 15. 98 & 17. 9 \\
\hline $\begin{array}{l}\operatorname{lmx} P S A \& ~ \\
\text { イナパック }\end{array}$ & 2 & 4. $99 \pm$ & 0.00 & 0.0 & 2 & 57. $45 \pm$ & 0.78 & 1. 4 \\
\hline $\begin{array}{l}\text { イムハPS } \\
\text { A糸トトバィ } \\
\text { エル」 }\end{array}$ & 2 & 5. $10 \pm$ & 0.00 & 0.0 & 2 & $60.15 \pm$ & 0.21 & 0.4 \\
\hline
\end{tabular}


(続き)

\begin{tabular}{|c|c|c|c|c|c|c|c|c|}
\hline \multirow{3}{*}{ キット名 } & \multicolumn{5}{|c|}{ PA (PSA) } & \multicolumn{3}{|c|}{ (単位： $\mathrm{ng} / \mathrm{ml}$ ) } \\
\hline & \multicolumn{4}{|c|}{ 試料 B-1 } & \multicolumn{4}{|c|}{ 試料 B -2 } \\
\hline & $\mathbf{N}$ & Mean \pm & S. D. & C. $v$. & $\mathbf{N}$ & Mean \pm & S. D. & C. $v$. \\
\hline $\begin{array}{l}\text { 亏ัンリームP } \\
\text { S A }\end{array}$ & 2 & 10. $81 \pm$ & 0.12 & 1. 1 & 2 & 123. $18 \pm$ & 0.74 & 0.6 \\
\hline 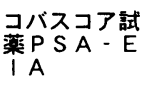 & 1 & 16.00 & 0.00 & 0.0 & 1 & 178. 50 & 0.00 & 0.0 \\
\hline$\underset{\mathrm{PA}}{\text { PーキットM }}$ & 1 & 0.00 & 0.00 & 0.0 & 1 & 20. 00 & 0.00 & 0.0 \\
\hline 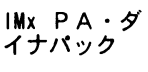 & 1 & 9. 39 & 0.00 & 0.0 & 1 & 97.00 & 0.00 & 0.0 \\
\hline $\begin{array}{l}\text { タンデム-M } \\
\text { P PSA E } \\
\text { L ISAキッ }\end{array}$ & 1 & 4. 40 & 0.00 & 0.0 & 1 & 37. 80 & 0.00 & 0.0 \\
\hline $\begin{array}{l}\text { コスメディ・ } \\
\text { F-PSA }\end{array}$ & 1 & 5. 00 & 0.00 & 0.0 & 1 & 60.70 & 0.00 & 0.0 \\
\hline $\begin{array}{l}\text { エルピアエー } \\
\text { スPSA }\end{array}$ & 1 & 9. 05 & 0.00 & 0.0 & 1 & 97.07 & 0.00 & 0.0 \\
\hline
\end{tabular}




\begin{tabular}{|c|c|c|c|c|c|c|c|c|}
\hline \multirow{3}{*}{ キット名 } & \multicolumn{5}{|c|}{ B 2-マ1タם } & \multicolumn{3}{|c|}{ （単位： $\mu \mathrm{g} / \mathrm{ml}$ ) } \\
\hline & & 試料 $\mathrm{E}$ & $3-1$ & & & 侙料 & $B-2$ & \\
\hline & $N$ & & S. D. & C. V. & $\mathbf{N}$ & Mean \pm & S. D. & C. V. \\
\hline \multirow{2}{*}{$\begin{array}{l}\beta 2-M G \text { 2 M } \\
\text { シオノギ }\end{array}$} & 18 & 1. $44 \pm$ & 0.10 & 7. 2 & 18 & 4. $56 \pm$ & 0.25 & 5. 5 \\
\hline & 17 & 1. $43 \pm$ & 0.09 & 6. 0 & 17 & 4. $59 \pm$ & 0.21 & 4. 5 \\
\hline 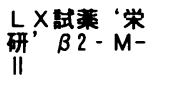 & 13 & $1.62 \pm$ & 0.29 & 17. 7 & 13 & 4. $93 \pm$ & 0.32 & 6.4 \\
\hline $\begin{array}{l}\text { B2-マイクロ } \\
\text { ・リアビース }\end{array}$ & 7 & 1. $38 \pm$ & 0.14 & 10.4 & 7 & 4. $43 \pm$ & 0.30 & 6. 9 \\
\hline 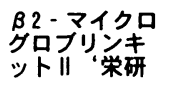 & 7 & 1. $47 \pm$ & 0.11 & 7. 4 & 7 & 5. $11 \pm$ & 0.14 & 2. 8 \\
\hline $\begin{array}{l}\text { エルピアエー } \\
\text { ス } 2 \mathrm{~m}(\mathrm{~S})\end{array}$ & 4 & 1. $50 \pm$ & 0.14 & 9. 0 & 4 & 4. $84 \pm$ & 0.05 & 1. 0 \\
\hline$\underset{2-M}{\mu ミ ハ ゚ ル ス ~}$ & 4 & 1. $20 \pm$ & 0.09 & 7.2 & 4 & 3. $96 \pm$ & 0.24 & 6. 2 \\
\hline $\begin{array}{l}\text { スパックーS } \\
\beta 2-マ イ タ \\
\text { ロキット }\end{array}$ & 3 & 1. $58 \pm$ & 0.02 & 1.3 & 3 & 4. $88 \pm$ & 0.15 & 3. 2 \\
\hline 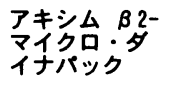 & 3 & 1. $23 \pm$ & 0.11 & 9.2 & 3 & 3. $82 \pm$ & 0.30 & 7. 9 \\
\hline 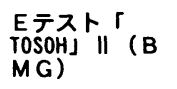 & 3 & 1. $43 \pm$ & 0.07 & 4. 8 & 3 & 4. $65 \pm$ & 0.47 & 10. 2 \\
\hline $\begin{array}{l}\text { エルビアエー } \\
\text { ス }\end{array}$ & 3 & 1. $64 \pm$ & 0.13 & 8. 0 & 3 & 5. $13 \pm$ & 0.32 & 6. 3 \\
\hline $\begin{array}{l}\text { スベリオルB } \\
\text { ETA-\| }\end{array}$ & 3 & 1. $27 \pm$ & 0.12 & 9.1 & 3 & 4. $17 \pm$ & 0.55 & 13. 2 \\
\hline $\begin{array}{l}\beta 2-マ イ ク ロ \\
\neq ッ ト \text { 第一 } \\
\text { J }\end{array}$ & 2 & $1.83 \pm$ & 0.10 & 5.4 & 2 & 5. $50 \pm$ & 0.71 & 12. 9 \\
\hline 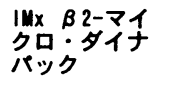 & 2 & 1. $18 \pm$ & 0.04 & 3. 4 & 2 & 3. $71 \pm$ & 0.09 & 2. 6 \\
\hline $\begin{array}{l}\text { クラオサイA } \\
{\left[\begin{array}{l}{[N] \text { B }} \\
(B)\end{array}\right.}\end{array}$ & 2 & 1. $42 \pm$ & 0.00 & 0.0 & 2 & 4. $99 \pm$ & 0.42 & 8. 4 \\
\hline $\begin{array}{l}\text { イムノティク } \\
\text { ルスオード } \\
2-\mathrm{m}\end{array}$ & 2 & $1.60 \pm$ & 0.00 & 0.0 & 2 & 5. $10 \pm$ & 0.00 & 0.0 \\
\hline ランリリームB $^{2}$ & 2 & 1. $27 \pm$ & 0.04 & 3. 3 & 2 & 4. $19 \pm$ & 0.13 & 3. 2 \\
\hline
\end{tabular}




\begin{tabular}{|c|c|c|c|c|c|c|c|c|}
\hline \multirow{3}{*}{ キット名 } & \multicolumn{5}{|c|}{ B 2-マ1タロダ ロプリン } & \multicolumn{3}{|c|}{ (単位： $\mu \mathrm{g} / \mathrm{ml}$ ) } \\
\hline & \multicolumn{4}{|c|}{ 試料 B -1 } & \multicolumn{4}{|c|}{ 試料 B -2 } \\
\hline & $\mathbf{N}$ & Mean \pm & S. D. & C. V. & $\mathbf{N}$ & Mean \pm & S. D. & C. V. \\
\hline $\begin{array}{l}\text { BMG - ¿ラテ } \\
\text { ツクス (II) } \\
\text { 「生研」 }\end{array}$ & 2 & 1. $20 \pm$ & 0.14 & 11. 8 & 2 & 4. $35 \pm$ & 0.07 & 1. 6 \\
\hline $\begin{array}{l}\text { ケミルミAC } \\
S-\beta 2 \mathrm{MG}\end{array}$ & 2 & 1. $49 \pm$ & 0.18 & 11.9 & 2 & 5. $14 \pm$ & 0.45 & 8. 8 \\
\hline $\begin{array}{l}\text { ファルマシア } \\
\beta 2 \text { 2 -マイクロ } \\
\text { リア }\end{array}$ & 1 & 1. 25 & 0.00 & 0.0 & 1 & 4. 36 & 0.00 & 0.0 \\
\hline 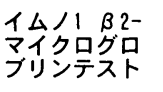 & 1 & 1. 28 & 0.00 & 0.0 & 1 & 3. 70 & 0.00 & 0.0 \\
\hline $\begin{array}{l}\text { acaパックß2- } \\
\text { マイクロログロ } \\
\text { フリリン }\end{array}$ & 1 & 1. 80 & 0.00 & 0.0 & 1 & 5. 40 & 0.00 & 0.0 \\
\hline$N$ Latex $\beta 2$ & 1 & 1. 07 & 0.00 & 0.0 & 1 & 3. 38 & 0.00 & 0.0 \\
\hline
\end{tabular}




\begin{tabular}{|c|c|c|c|c|c|c|c|c|}
\hline \multirow{3}{*}{ キット名 } & \multicolumn{5}{|c|}{ フェリチン } & \multicolumn{3}{|c|}{ （単位：ng/ml) } \\
\hline & & 試料 & $3-1$ & & & 試料 & $B-2$ & \\
\hline & $\mathbf{N}$ & Mean \pm & S. D. & C. V. & $\mathbf{N}$ & Mean \pm & S. D. & C. V. \\
\hline \multirow{2}{*}{$\begin{array}{l}\text { ケミルミAC } \\
\text { Sーフェリチ } \\
\text { シ }\end{array}$} & \multirow[t]{2}{*}{15} & \multirow[t]{2}{*}{$39.25 \pm$} & \multirow[t]{2}{*}{ 4. 60} & \multirow[t]{2}{*}{11.7} & 15 & 294. $25 \pm$ & 14. 33 & 4. 9 \\
\hline & & & & & 14 & $291.59 \pm$ & 10. 36 & 3. 6 \\
\hline $\begin{array}{l}\text { フェリチンキ } \\
\text { ット「第一」 }\end{array}$ & 11 & 33. $96 \pm$ & 3. 18 & 9. 4 & 11 & 205. $38 \pm$ & 12. 61 & 6. 1 \\
\hline $\begin{array}{l}\text { ルミパルスフ } \\
\text { ェリチン }\end{array}$ & 7 & 24. $73 \pm$ & 2. 18 & 8. 8 & 7 & $214.66 \pm$ & 8. 55 & 4. 0 \\
\hline フェリチン・ & 6 & 29. $21 \pm$ & 0.50 & 1. 7 & 6 & 174. $18 \pm$ & 7. 36 & 4. 2 \\
\hline ランリームF & 6 & $40.66 \pm$ & 8. 83 & 21.7 & 6 & 276. $97 \pm$ & 32.84 & 11.9 \\
\hline $\begin{array}{l}\text { スパック-S } \\
\text { フェッリチン } \\
\text { キット }\end{array}$ & 5 & 29. $13 \pm$ & 2. 16 & 7. 4 & 5 & 229. $77 \pm$ & 18. 25 & 7. 9 \\
\hline $\begin{array}{l}\text { アキシムム フ } \\
\text { エリチン・タ } \\
\text { イチバック }\end{array}$ & 5 & 36. $40 \pm$ & 3. 01 & 8. 3 & 5 & $319.44 \pm$ & 31.89 & 10. 0 \\
\hline $\begin{array}{l}\text { エルピアェー } \\
\text { スフェリチン }\end{array}$ & 5 & 45. $32 \pm$ & 2. 90 & 6.4 & 5 & 286. $40 \pm$ & 17. 29 & 6. 0 \\
\hline 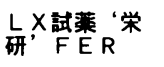 & 5 & 39. $70 \pm$ & 7. 73 & 19. 5 & 5 & $311.60 \pm$ & 23. 94 & 7. 7 \\
\hline $\begin{array}{l}\text { ケミルミAC } \\
\text { Sーフェリチチン } \\
\text { (ケンタウルス }\end{array}$ & 4 & 38. $53 \pm$ & 5. 98 & 15.5 & 4 & 295. $25 \pm$ & 6.50 & 2. 2 \\
\hline ガンマー・多 & 3 & $30.03 \pm$ & 7. 45 & 24. 8 & 3 & 259. $91 \pm$ & 65.55 & 25. 2 \\
\hline フェリチン・ & 2 & 29. $78 \pm$ & 20. 39 & 68.5 & 2 & $310.67 \pm$ & 21.67 & 7. 0 \\
\hline $\begin{array}{l}\text { ビトロスフェ } \\
\text { リチン }\end{array}$ & 2 & 28. $80 \pm$ & 0.57 & 2. 0 & 2 & 202. $00 \pm$ & 1. 41 & 0.7 \\
\hline $\begin{array}{l}\text { Eテスト「 } \\
\text { TOSOH」 } \\
\text { エリチン) }\end{array}$ & 2 & 45. $85 \pm$ & 6. 29 & 13. 7 & 2 & $257.00 \pm$ & 8. 49 & 3. 3 \\
\hline $\begin{array}{l}\text { グラオザイム } \\
\text { [New] FER }\end{array}$ & 2 & 32. $30 \pm$ & 2. 97 & 9. 2 & 2 & $267.35 \pm$ & 10.54 & 3. 9 \\
\hline $\begin{array}{l}\text { IMx ファェリチ } \\
\text { ック } \\
\text { ックチバ }\end{array}$ & 2 & 33. $14 \pm$ & 1. 03 & 3. 1 & 2 & $299.83 \pm$ & 2. 02 & 0.7 \\
\hline
\end{tabular}


（続き）

\begin{tabular}{|c|c|c|c|c|c|c|c|c|}
\hline \multirow{3}{*}{ キット名 } & \multicolumn{5}{|c|}{ フェリチン } & \multicolumn{3}{|c|}{ （単位： $\mathrm{ng} / \mathrm{m} \mathrm{l}$ ) } \\
\hline & \multicolumn{4}{|c|}{ 試料 B -1 } & \multicolumn{4}{|c|}{ 試料 B -2 } \\
\hline & $\mathrm{N}$ & Mean \pm & S. D. & C. V. & $\mathbf{N}$ & Mean 士 & S. D. & C. V. \\
\hline 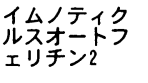 & 2 & 34. $67 \pm$ & 0.11 & 0.3 & 2 & 270. $20 \pm$ & 0.25 & 0.1 \\
\hline $\begin{array}{l}\text { エクルーシス } \\
\text { フェッシ }\end{array}$ & 2 & 40. $87 \pm$ & 1. 61 & 3. 9 & 2 & $291.67 \pm$ & 14. 90 & 5. 1 \\
\hline 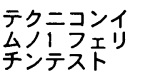 & 1 & 39. 70 & 0.00 & 0.0 & 1 & 282. 20 & 0.00 & 0.0 \\
\hline 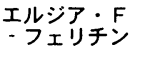 & 1 & 30. 40 & 0.00 & 0.0 & 1 & 259. 70 & 0.00 & 0.0 \\
\hline $\begin{array}{l}\text { FE R-ラテッ } \\
\text { クス「生研」 }\end{array}$ & 1 & 41. 00 & 0.00 & 0.0 & 1 & 304. 00 & 0.00 & 0.0 \\
\hline $\begin{array}{l}\text { イアトロメイ } \\
\text { トラリチシ }\end{array}$ & 1 & 52. 50 & 0.00 & 0.0 & 1 & 298. 50 & 0.00 & 0.0 \\
\hline ルミノマスタ & 1 & 40.81 & 0.00 & 0.0 & 1 & 353. 12 & 0.00 & 0.0 \\
\hline $\begin{array}{l}\text { ルミ亲研゙ット } \\
\text { リチン }\end{array}$ & 1 & 35. 30 & 0.00 & 0.0 & 1 & 368. 00 & 0.00 & 0.0 \\
\hline
\end{tabular}

\begin{tabular}{|c|c|c|c|c|c|c|c|c|}
\hline \multirow[b]{2}{*}{ キット名 } & \multicolumn{5}{|c|}{ NSE } & \multicolumn{3}{|c|}{ （単位：ng/mI） } \\
\hline & $\mathbf{N}$ & $\begin{array}{c}\text { 試料 } \\
\operatorname{Mean}^{-1} \pm\end{array}$ & $\begin{array}{l}3-1 \\
\text { S. D. }\end{array}$ & C. V. & $\mathbf{N}$ & \multicolumn{2}{|c|}{ 試料 B -2 } & C. V. \\
\hline $\begin{array}{l}\text { プロリフィゲ } \\
\text { YNS SNEキッ } \\
\text { ト「第一」 }\end{array}$ & 10 & 7. $14 \pm$ & 0.39 & 5. 5 & 10 & $37.66 \pm$ & 1. 26 & 3. 4 \\
\hline NSE “栄研 & 9 & 5. $62 \pm$ & 1. 35 & 24. 1 & 9 & 35. $24 \pm$ & 4. 67 & 13. 2 \\
\hline \multirow{2}{*}{$\begin{array}{l}\text { ファルママシア } \\
\text { NSEリア }\end{array}$} & 8 & 7. $35 \pm$ & 0.61 & 8. 3 & 8 & 34. $65 \pm$ & 3. 25 & 9. 4 \\
\hline & 7 & 7. $54 \pm$ & 0.33 & 4. 3 & & & & \\
\hline $\begin{array}{l}\text { エルザN S E } \\
\text { キット }\end{array}$ & 6 & $6.66 \pm$ & 0.73 & 10. 9 & 6 & 38. $95 \pm$ & 1. 02 & 2. 6 \\
\hline 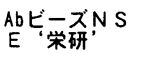 & 5 & 7. $29 \pm$ & 0.33 & 4. 5 & 5 & 43. $04 \pm$ & 3. 57 & 8. 3 \\
\hline $\begin{array}{l}\text { コバスコアN } \\
S E \| \text { IIA }\end{array}$ & 2 & 4. $15 \pm$ & 0.21 & 5. 1 & 2 & 35. $50 \pm$ & 1. 98 & 5. 6 \\
\hline $\begin{array}{l}E \text { IA NS } \\
\text { E } \\
P\end{array}$ & 1 & 3. 50 & 0.00 & 0.0 & 1 & 28. 30 & 0.00 & 0.0 \\
\hline
\end{tabular}

注 各欄下段の数字は、 $\mathrm{M} \pm 2 \mathrm{SD}$ 以内のデータによる再計算值。 
表 8.1 キット内・キット間における变動（isotopic法による系）

\begin{tabular}{|c|c|c|c|c|c|c|c|c|}
\hline \multirow{2}{*}{ 項 } & \multicolumn{3}{|c|}{ Within kit Variation $[\mathrm{CV}(\%)]$} & \multicolumn{4}{|c|}{ Between kit Variation [CV(\%)] } & \multirow{2}{*}{$\begin{array}{l}\text { 試 } \\
\text { 料 }\end{array}$} \\
\hline & 試料 1 & 試料 2 & 試料 3 & 試料 1 & 試料 2 & 試料 & 3 & \\
\hline GH & 7. $8(41)$ & $6.5(41)$ & $5.0(40)$ & $9.1(2)$ & $12.5(2)$ & 18.5 & & $\mathrm{~A}$ \\
\hline ソマトメジンC & $11.5(17)$ & $10.1 \quad(18)$ & 8. $9(17)$ & $20.8(3)$ & 24.3 (3) & 39.4 & (3) & A \\
\hline F S H I*1 & 5. 2 (33) & 4. $0(34)$ & $5.0(34)$ & $26.0(3)$ & 27.0 & 34.6 & (3) & A \\
\hline $\mathrm{LH} \quad \mathrm{I}^{* 2}$ & 6. $4(33)$ & 5. $3(34)$ & $6.8(34)$ & $43.6(3)$ & $22.2(3)$ & 20. 9 & (3) & $\mathrm{A}$ \\
\hline プロラクチン I *3 & 3. $1 \quad(4)$ & 4. $3 \quad(4)$ & $2.6 \quad(4)$ & - & - & - & & $\mathrm{A}$ \\
\hline プロラクチン II *4 & $6.5(24)$ & 7. 8 (25) & 6. $4(24)$ & $5.2(2)$ & $10.5(2)$ & 22. 7 & (2) & $\mathrm{A}$ \\
\hline プロラクチン III*5 & - & $6.7 \quad(2)$ & 5. $3 \quad(2)$ & - & - & - & & A \\
\hline T S H & $11.6(45)$ & $10.9(46)$ & 8. $0(46)$ & $10.9(6)$ & $10.4(6)$ & 10.6 & (6) & A \\
\hline $\mathrm{T}_{3}$ & $8.9(35)$ & 4. $5(35)$ & 5. $2(35)$ & $9.1(7)$ & 9. $9(7)$ & 11. 2 & $(7)$ & A \\
\hline Free $\mathrm{T}_{3}$ & 6. $7(37)$ & 5. $6(39)$ & 5. $3(38)$ & $21.3(4)$ & $26.6(4)$ & 37. 3 & $(4)$ & A \\
\hline $\mathrm{T}_{4}$ & 8. $2(33)$ & $6.0(32)$ & 5. 0 (32) & $1.9(7)$ & $6.2(7)$ & 7. 6 & (7) & A \\
\hline Free $T_{4}$ & 7. $6(40)$ & 7. $2(42)$ & $10.6(41)$ & $36.9(6)$ & $43.8(6)$ & 47. 0 & (6) & A \\
\hline T B G & 4. $6(22)$ & 3. 7 (22) & 6. 1 (23) & $11.0(2)$ & 18.1 (2) & 19. 2 & (2) & A \\
\hline カルシトニン & 25.2 & $12.0 \quad(22)$ & $12.3(22)$ & $40.8(4)$ & $19.8(4)$ & 21. 9 & (4) & A \\
\hline インス & 8. $5(65)$ & 5. $3(66)$ & 4. $3(66)$ & 16. $9(6)$ & $12.7(6)$ & 15.7 & (6) & A \\
\hline Cーペプチド & $6.2(54)$ & $6.7(54)$ & 7. $3(55)$ & $22.5(2)$ & 23.1 (2) & 28. 9 & (2) & A \\
\hline グルカゴン & 13. 0 (13) & 11.9 (13) & 8. 8 (12) & - & - & - & & A \\
\hline ストリン & 15. 7 (23) & 6. $4 \quad(22)$ & 7. 6 (23) & - & - & - & & A \\
\hline テストステロン & $15.5(22)$ & 4. 7 (23) & $11.3(21)$ & $31.5 \quad(3)$ & 21.1 (3) & 34.6 & (3) & A \\
\hline ee テストステロン & 16. $8 \quad(9)$ & 7. $8 \quad(9)$ & $3.5 \quad(8)$ & - & - & - & & A \\
\hline ストラジオール & 17. 4 (28) & $12.8(30)$ & 9. 7 (27) & 13.6(4) & 24. 2 (4) & 40. 0 & (4) & A \\
\hline プロゲステロン & $6.8(27)$ & 4. 9 (26) & $6.6(27)$ & 37.8 (3) & 30.0 & 42. 3 & (3) & A \\
\hline$\beta \mathrm{HC} \mathrm{G} \mathrm{I} \quad \mathrm{I}^{* 6}$ & - & $10.8 \quad(6)$ & 4. $9 \quad(8)$ & - & - & - & & A \\
\hline $17 \alpha$-ヒド ロ抽プロ吹 ステロン & - & $27.4 \quad(6)$ & $23.8 \quad(6)$ & - & - & - & & A \\
\hline アルドステロン & 10. $6(49)$ & 9. $3(50)$ & 8. 1 (48) & 29. 8 (3) & 10.1 & 10. 5 & (3) & A \\
\hline ルチゾール & 8. 5 (37) & 7. 7 (38) & 8. $5(36)$ & 18. 5 (5) & 14. 9 (5) & 15.5 & (5) & A \\
\hline $\mathrm{IEA}-\mathrm{S}$ & 10.9 (12) & 5. 5 (11) & 3. 7 (11) & 20. 9 (2) & 37.4 (2) & 14. 3 & (2) & A \\
\hline レニン定量 & 5. 4 (17) & 6. $2(17)$ & 7. $8(17)$ & - & - & - & & A \\
\hline I g E & 5. $4(32)$ & 5. $5(33)$ & 7. $0(32)$ & $6.0(7)$ & 9. $9(7)$ & 9. 7 & (7) & A \\
\hline ジゴキシ & 5. 2 (2) & 4. 8 (2) & $1.2 \quad(2)$ & - & - & - & & A \\
\hline$\alpha$-フェトプロテイン & 7. 7 (43) & 7. $2(43)$ & 9. 2 (43) & 10. $3(6)$ & $10.2(6)$ & 7. 7 & $(6)$ & A \\
\hline C E A & $12.7(41)$ & 9. 1 (43) & - & $69.5(4)$ & 89. 9 (4) & - & & B \\
\hline T P A & $12.5(37)$ & - & - & 37. 5（2） & - & - & & B \\
\hline C A 125 & $5.8(48)$ & $5.0(47)$ & - & 14. $6(3)$ & 13.7 (3) & - & & B \\
\hline C A $19-9$ & 13. 2 (48) & $9.7(48)$ & - & 16. 4(3) & $18.8(3)$ & - & & B \\
\hline C A $15-3$ & 9. 9 (34) & 9. 1 (32) & - & $6.7(3)$ & 4. 1 (3) & - & & B \\
\hline P A P & 4. 8 (21) & 13. 6 (18) & - & 28. 3 (4) & 34.9 (3) & - & & B \\
\hline P A (P S A) & 12. 3 (21) & 6. $1(20)$ & - & $5.8(3)$ & $10.6(3)$ & - & & B \\
\hline$\beta_{2}{ }_{2}$-マイクログロ & 7. $0(36)$ & 5. $3(36)$ & - & 8. $1(6)$ & 7. $2(6)$ & - & & B \\
\hline フェリチン & 17. 4 (27) & 10.9 (27) & - & 3. 2 (5) & 19. 2 (5) & - & & B \\
\hline NSE & 11. $6(37)$ & 8. 3 (38) & - & 11. 1 (5) & 7. 5 (5) & - & & B \\
\hline
\end{tabular}

注 各項の（）は測定系数。

注*1 スタンダードが、WHO 2nd IRP 78/549 に準拠している系。

注*2 スタンダードが、WHO 1st IRP 68/40 に準拠している系。

注*3 スタンダードが、N I H VLS \#4 に準拠している系。

注*4 スタンダードが、WHO 1st IRP 75/504 に準拠している系。

注*5 スタンダードが、WHO 2nd IRP 83/562 に準拠している系。

注*6 単位が、ng/mlの系。 
表 8.2 キット内・キット間における変動（non-i soopic法による系）

\begin{tabular}{|c|c|c|c|c|c|c|c|}
\hline & \multicolumn{3}{|c|}{ Within kit Variation $[\mathrm{CV}(\%)]$} & \multicolumn{3}{|c|}{ Between kit Variation $[\mathrm{CV}(\%)]$} & \multirow{2}{*}{$\begin{array}{l}\text { 試 } \\
\text { 料 }\end{array}$} \\
\hline & 試料 1 & 試料 2 & 試料 3 & 試料 1 & 試料 2 & 試料 3 & \\
\hline GH & $5.9(8)$ & $3.7(8)$ & $3.7(8)$ & $4.0(2)$ & 1.1 (2) & $5.5(2)$ & $\mathrm{A}$ \\
\hline F S H I ${ }^{* 1}$ & 8. $6(31)$ & 6. $4(31)$ & 6. $9(31)$ & 16. $0(12)$ & 15. $8(12)$ & 14. $6(12)$ & $\mathrm{A}$ \\
\hline $\mathrm{F} \mathrm{SH} \mathrm{II} * 2$ & 4. $3(18)$ & 3. $4(16)$ & 3. $6(17)$ & - & - & - & $\mathrm{A}$ \\
\hline $\mathrm{LH} \quad \mathrm{I} * 3$ & 8. $3(23)$ & $9.1(24)$ & 9. $7(24)$ & $12.1(6)$ & $8.2(6)$ & $6.6(6)$ & $\mathrm{A}$ \\
\hline L H III *4 & 9. $3(23)$ & $6.5(23)$ & 6. $2(23)$ & $13.3(8)$ & $16.8(8)$ & $19.4(8)$ & $\mathrm{A}$ \\
\hline プロラクチン III ${ }^{* 5}$ & 6. 0 (2) & 4. 3 (2) & $10.9(2)$ & - & - & - & $\mathrm{A}$ \\
\hline プロラクチン IN*6 & 6. $7(40)$ & 6. $5(41)$ & 6. $3(40)$ & 16. $8(13)$ & 19. $5(13)$ & 19. $8(13)$ & A \\
\hline T S H & 6. $4(70)$ & 4. $2(71)$ & 5. $2(71)$ & $21.4(15)$ & $15.5(15)$ & 11. 2(15) & A \\
\hline $\mathrm{T}_{3}$ & 7. $7(54)$ & 4. $3(54)$ & 2. $5(55)$ & 10. $8(13)$ & 12. $7(13)$ & $11.6(13)$ & A \\
\hline Free $\mathrm{T}_{3}$ & 7. $3(62)$ & 7. $7(62)$ & 6. $7(61)$ & $21.1(16)$ & $30.5(16)$ & $42.0(16)$ & $\mathrm{A}$ \\
\hline $\mathrm{T}_{4}$ & 7. $8(57)$ & 3. $9(57)$ & 3. $1(58)$ & $15.4(13)$ & 7. $7(13)$ & 9. $2(13)$ & $\mathrm{A}$ \\
\hline Free $\mathrm{T}_{4}$ & 8. $4(67)$ & 6. $2(69)$ & 7. $6(64)$ & 25. $3(15)$ & 59. 6(15) & $34.6(15)$ & A \\
\hline T B G & - & - & - & 4.9 (2) & 5.8 (2) & 2. 3 (2) & $\mathrm{A}$ \\
\hline インスリン & 6. 6(34) & 6. $9(36)$ & 7. $6(36)$ & $15.1(10)$ & 15. $5(10)$ & 18. $5(10)$ & A \\
\hline C-ペプチド & 2. 6 (9). & 3. $4(10)$ & 6. $0(10)$ & 6.4 (2) & 5.0 (2) & 5. 6 (2) & A \\
\hline テストステロン & 8. $2(13)$ & 4. $2(13)$ & $12.3(13)$ & $41.3(5)$ & $14.5 \quad(5)$ & $16.8 \quad(5)$ & $\mathrm{A}$ \\
\hline エストラジオール & 9. $6(30)$ & 7. $0(30)$ & 9. $9(30)$ & 30. $2(10)$ & $35.5(10)$ & $60.4(10)$ & A \\
\hline プロゲステロン & 10. $1(23)$ & $12.1(24)$ & 8. $4(24)$ & 30.5 (9) & $17.6(9)$ & $23.8 \quad(9)$ & $\mathrm{A}$ \\
\hline$\beta \mathrm{HC} \mathrm{G} \mathrm{I} \mathrm{I}^{* 7}$ & 12.4 (3) & $7.5 \quad(3)$ & 8. 9 (3) & - & - & - & $\mathrm{A}$ \\
\hline$\beta \mathrm{HC} \mathrm{G} \mathrm{II*8}$ & 7. $5(12)$ & $5.1(12)$ & 5. $5(12)$ & $9.5 \quad(5)$ & $2.0 \quad(5)$ & 7. $6(5)$ & $\mathrm{A}$ \\
\hline コルチゾール & 10. 1(24) & 5. $1(24)$ & 6. $0(24)$ & $18.9(10)$ & $11.3(10)$ & 10. $5(10)$ & $\mathrm{A}$ \\
\hline$I$ g E & 7. $7(45)$ & 5. $7(46)$ & 7. $6(46)$ & 8. $5(17)$ & 8. $6(17)$ & 10. $0(17)$ & $\mathrm{A}$ \\
\hline ジゴキシン & 9. $8(34)$ & 4. $6(36)$ & 4. $5(36)$ & 14. $9(11)$ & 7. $5(11)$ & 8. $3(11)$ & A \\
\hline$\alpha$-フェトプロテイン & 5. $7(59)$ & 6. $9(60)$ & 8. $2(60)$ & 7. $2(16)$ & $5.4(16)$ & 5. $4(16)$ & A \\
\hline C E A & 9. $3(56)$ & 8. $1(57)$ & - & 44. $4(16)$ & $51.4(16)$ & - & $B$ \\
\hline C A 125 & 6. $7(39)$ & 5. $6(39)$ & - & $25.5(11)$ & $28.9(11)$ & - & $\mathrm{B}$ \\
\hline C A $19-9$ & 9. $8(51)$ & 5. $8(52)$ & - & 27. $7(14)$ & 15. 5(14) & - & $B$ \\
\hline C A $15-3$ & 13. $9(18)$ & 8. $5(18)$ & - & $13.1(7)$ & 8.1 (7) & - & $B$ \\
\hline P A P & 5. $1(14)$ & 14. $2(12)$ & - & $29.0 \quad(6)$ & $26.7(6)$ & - & $B$ \\
\hline PA $(P S A)$ & 10. $1(53)$ & $12.6(52)$ & - & $45.4(20)$ & 44. $2(20)$ & - & $B$ \\
\hline$\beta_{2}{ }_{2}$-マイクログロブリン & 13. $6(45)$ & 6. $9(45)$ & - & $11.1(16)$ & 11. $3(16)$ & - & $\mathrm{B}$ \\
\hline フェリチン & 13. $5(59)$ & 6. $5(58)$ & - & 15. $0(19)$ & 12. $2(19)$ & - & $B$ \\
\hline NSE & $5.4(2)$ & $6.0 \quad(2)$ & - & 10. $7(2)$ & 14.5 (2) & - & B \\
\hline
\end{tabular}

注各項の（）は測定系数。

注*1 スタンダードが、WHO 2nd IRP 78/549 に準拠している系。

注*2 スタンダードが、WHO 2nd IRP 94/632 に準拠している系。

注*3 スタンダードが、WHO 1st IRP 68/40 に準拠している系。

注*4 スタンダードが、WHO 2nd IRP 80/552 に準拠している系。

注*5 スタンダードが、WHO 2nd IRP 83/562 に準拠している系。

注*6 スタンダードが、WHO 3rd IRP 84/500 に準拠している系。

注 $* 7$ 単位が、 $\mathrm{ng} / \mathrm{m} /$ の系。

注*8 単位が、mIU/mlの系。 
表 8.3 キット内・キット間における変動（i sotopic法及びnon-i sotopic法による系）

\begin{tabular}{|c|c|c|c|c|c|c|c|}
\hline \multirow{2}{*}{ 項 } & \multicolumn{3}{|c|}{ Within kit Variation $[\mathrm{CV}(\%)]$} & \multicolumn{3}{|c|}{ Between kit Variation $[\mathrm{CV}(\%)]$} & \multirow{2}{*}{$\begin{array}{l}\text { 試 } \\
\text { 料 }\end{array}$} \\
\hline & 試料 1 & 試料 2 & 試料 3 & 試料 1 & 試料 2 & 試料 3 & \\
\hline GH & 7. 8 (49) & $6.5(49)$ & $5.1(48)$ & $18.4(4)$ & $20.0(4)$ & 24. $2(4)$ & A \\
\hline ソマトメジンC & $11.5(17)$ & $10.1(18)$ & 8. 9 (17) & 20.8 (3) & $24.3(3)$ & 39.4 (3) & A \\
\hline $\mathrm{F} \mathrm{SH} \mathrm{I}^{* 1}$ & 6. $7 \quad(64)$ & $5.1 \quad(65)$ & $5.9 \quad(65)$ & 18. 1(15) & 17. $3(15)$ & 19. $2(15)$ & A \\
\hline $\mathrm{F} \mathrm{S} \mathrm{H} \mathrm{II} * 2$ & 4. $3(18)$ & $3.4(16)$ & 3. 6 (17) & - & - & - & A \\
\hline $\mathrm{LH} \mathrm{I*3}$ & 7. $2(56)$ & 7. $4(58)$ & $8.9(58)$ & 24. $3(9)$ & $17.1(9)$ & $34.4(9)$ & A \\
\hline L H III ${ }^{* 4}$ & 9. 3 (23) & $6.5(23)$ & $6.2(23)$ & $13.3(8)$ & $16.8(8)$ & 19. 4 (8) & A \\
\hline プロラクチン I ${ }^{* 5}$ & 3.1 (4) & 4. $3 \quad(4)$ & $2.6 \quad(4)$ & - & - & - & A \\
\hline プロラクチン II *6 & $6.5(24)$ & 7. 8 (25) & $6.4(24)$ & 5. $2(2)$ & 10.5 (2) & 22.7 (2) & A \\
\hline プロラクチンIII* & 2. $6 \quad(4)$ & $6.9 \quad(4)$ & $7.0 \quad(4)$ & $55.6 \quad(2)$ & 57.1 (2) & 57. 3 (2) & A \\
\hline プロラクチンIN*8 & $6.7 \quad(40)$ & $6.5 \quad(41)$ & $6.3 \quad(40)$ & 16. $8(13)$ & 19. $5(13)$ & 19. $8(13)$ & A \\
\hline T S H & 9. $1(115)$ & 7. $4(117)$ & 6. 4(117) & 17. $2(21)$ & $13.4(21)$ & 11. $5(21)$ & A \\
\hline $\mathrm{T}_{3}$ & 8. 2 (89) & 4. 4 (89) & 3. $6(90)$ & 9. $4(20)$ & 14. $5(20)$ & 14. $2(20)$ & A \\
\hline Free $\mathrm{T}_{3}$ & 7. 1 (99) & 7. 1(101) & $6.1 \quad(99)$ & 24. $0(20)$ & 27. $9(20)$ & $34.5(20)$ & A \\
\hline $\mathrm{T}_{4}$ & 8. $0 \quad(90)$ & 4. 7 (89) & $3.9(90)$ & $11.5(20)$ & 6. $9(20)$ & 8. $1(20)$ & A \\
\hline Free $\mathrm{T}_{4}$ & 8. $1(107)$ & 6. $6(111)$ & 9. $3(105)$ & 24. $3(21)$ & $50.1(21)$ & $32.9(20)$ & A \\
\hline T B G & 4. 6 (22) & $3.8 \quad(22)$ & 6.1 (23) & 10.4 (4) & 16.5 (4) & 17. $3(4)$ & A \\
\hline カルシトニン & 25.2 (23) & $12.0(22)$ & 12. 3 (22) & 40.8 (4) & 19.8 (4) & 21.9 (4) & A \\
\hline インスリン & 7. 9 (99) & 5. $9(102)$ & 5. $5(102)$ & 15. $6(16)$ & 13. $2(16)$ & 16. 1(16) & A \\
\hline Cーペプチド & 5.8 (63) & $6.3(64)$ & 7. $1(65)$ & 19.4 (4) & 19.3 (4) & 24.2 (4) & A \\
\hline グルカゴン & $13.0 \quad(13)$ & $11.9(13)$ & 8. 8 (12) & - & - & - & A \\
\hline ガストリン & 15.7 (23) & 6.4 (22) & 7. 6 (23) & - & - & - & A \\
\hline テストステロン & 14.6 (35) & 4. $4(36)$ & $11.7(34)$ & 32.1 (8) & 22.1 (8) & 26.8 (8) & A \\
\hline Free テストステロン & $16.8 \quad(9)$ & 7. $8 \quad(9)$ & $3.5 \quad(9)$ & - & - & - & $\mathrm{A}$ \\
\hline エストラジオール & $11.6(58)$ & $10.3(59)$ & 9.8 (57) & $54.0(14)$ & 29. $6(14)$ & 48. $2(14)$ & A \\
\hline プロゲステロン & $8.4(50)$ & $9.0(50)$ & 7. $4 \quad(51)$ & 27. $6(12)$ & 17. $6(12)$ & 23. 7 (12) & A \\
\hline$\beta \mathrm{HCG} \quad I^{* 9}$ & $10.7 \quad(5)$ & $9.9 \quad(9)$ & $6.1(11)$ & 8. 2(2) & - & 3.8 (2) & A \\
\hline$\beta \mathrm{HC} \mathrm{G} \Pi^{* 10}$ & 7. 5 (12) & $5.1(12)$ & 5. 5 (12) & 9. 5 (5) & $2.0 \quad(5)$ & 7. $6(5)$ & A \\
\hline $17 \alpha$-ヒド ロ㧍プロ吹 ステロロ & - & $27.4 \quad(6)$ & $23.8 \quad(6)$ & - & - & - & A \\
\hline アルドステロン & $10.6(49)$ & 9. $3(50)$ & 8. 1 (48) & $29.8(3)$ & 10.1 (3) & 10.5 (3) & A \\
\hline コルチソール & 9. 1 (61) & $6.8(62)$ & 7. $6(60)$ & 18. $3(15)$ & 12. $8(15)$ & 12. $8(15)$ & A \\
\hline D HEA-S & $10.9(12)$ & 5.5 (11) & 3.7 (11) & $20.9(2)$ & 37.4 (2) & $14.3(2)$ & A \\
\hline レニン定量 & 5.4 (17) & $6.2(17)$ & $7.8(17)$ & - & - & - & A \\
\hline$I \mathrm{~g} \mathrm{E}$ & $6.9(77)$ & 5. $6(79)$ & 7. $4(78)$ & 8. $4(24)$ & 8. $7(24)$ & 9. $6(24)$ & A \\
\hline ジゴキシン & $9.7(36)$ & 4. $6(38)$ & 4. $4(38)$ & 14. $8(12)$ & 7. $3(12)$ & 8. $1(12)$ & A \\
\hline$\alpha$-フェトプロテイン & 6. $5(102)$ & 7. $0(103)$ & 8. $6(103)$ & 9. $6(22)$ & 9. $1(22)$ & 9. $0(22)$ & $\mathrm{A}$ \\
\hline C E A & $10.3(98)$ & 9. $0(100)$ & - & 73. $9(20)$ & 85. $2(20)$ & - & B \\
\hline T P A & 12. $3(37)$ & - & - & 38.0 (3) & - & - & B \\
\hline C A 125 & 6.2 (87) & $5.3(86)$ & - & $19.4(14)$ & 23. $2(14)$ & - & B \\
\hline C A $19-9$ & $11.7(99)$ & 8. $1(100)$ & - & $22.1(17)$ & 14. $0(17)$ & - & B \\
\hline C A $15-3$ & $11.1(52)$ & 8. $8(50)$ & - & 9. $8(10)$ & 10. $6(10)$ & - & B \\
\hline P A P & $5.0 \quad(35)$ & $14.1(30)$ & - & 28. $2(10)$ & 30.4 (9) & - & $B$ \\
\hline$P A(P S A)$ & $10.5(74)$ & $11.6(72)$ & - & 44. $9(23)$ & 43. $4(23)$ & - & B \\
\hline$\beta_{2}$-マイクログロ & $10.8(81)$ & 6. 2 (81) & - & 9. $9(22)$ & 9. $5(22)$ & - & $\mathrm{B}$ \\
\hline フェリチン & $14.5(86)$ & 7. 7 (85) & - & 15. $4(24)$ & 17. $7(24)$ & - & B \\
\hline NSE & $11.8(39)$ & 8. $3(40)$ & - & 16. 5 (7) & 8.1 (7) & - & B \\
\hline
\end{tabular}


注 各項の（）は測定系数。

注*1 スタンダードが、WHO 2nd IRP 78/549 に準拠している系。 注*2 スタンダードが、WHO 2nd IRP 94/632 に準拠している系。

注*3 スタンダードが、WHO 1st IRP 68/40 に準拠している系。 注*4 スタンダードが、WHO 2nd IRP 80/552 に準拠している系。 注*5 スタンダードが、N I H VLS \#4 に準拠している系。

注*6 スタンダードが、WHO 1st IRP 75/504 に準拠している系。 注*7 スタンダードが、WHO 2nd IRP 83/562 に準拠している系。 注*8 スタンダードが、WHO 3rd IRP 84/500 に準拠している系。 注 $* 9$ 単位が、ng/mlの系。

注*10 単位が、mIU/mlの系。 
表 9.1 キット内変動俰数（Within kit Variation CV (\%)) の推移 （i sotopic法による系）

\begin{tabular}{|c|c|c|c|c|c|c|c|}
\hline 項 & 目 & 第15回 & 第16回 & 第17回 & 第18回 & 第19回 & 第20回 \\
\hline \multirow{3}{*}{ GH } & 試料 1 & 8.1 & 7. 6 & 9.8 & 8. 0 & 6.4 & 7.8 \\
\hline & 試料 2 & 7. 0 & 5. 5 & 8.7 & 7. 8 & 6.3 & 6.5 \\
\hline & 試料 3 & 7. 0 & 5.8 & 6. 6 & 6.5 & 5.8 & 5.1 \\
\hline \multirow{3}{*}{ ソマトメジンC } & 試料 1 & 10. 9 & 20.8 & 8.8 & 10.5 & 8.7 & 11.5 \\
\hline & 試料 2 & 8.8 & 13.7 & 7. 3 & 8.0 & 15.6 & 10.1 \\
\hline & 試料 3 & 9. 4 & 19. 4 & 8.1 & 10.7 & 9. 0 & 8.9 \\
\hline \multirow{3}{*}{ F S H } & 試料 1 & 8. 0 & 6.3 & 5.7 & 11.4 & 3.9 & 5. 2 \\
\hline & 試料 2 & 8. 2 & 5.7 & 5.6 & 7. 1 & 3. 9 & 4. 0 \\
\hline & 試料 3 & 6.4 & 5.1 & 4. 2 & 4. 4 & 4. 6 & 5.0 \\
\hline \multirow{3}{*}{$\mathrm{LH}$} & 試料 1 & 9. 1 & 8. 3 & 7. 5 & 10.5 & 10.5 & 6.4 \\
\hline & 試料 2 & 6.7 & 5.8 & 6.4 & 5.1 & 5. 5 & 5. 3 \\
\hline & 試料 3 & 8. 0 & 6.4 & 5.7 & 7. 9 & 3. 4 & 6.8 \\
\hline \multirow{3}{*}{ プロラクチン } & 試料 1 & 9.8 & 15. 2 & 12.1 & 8. 4 & 18. 9 & 5. 0 \\
\hline & 試料 2 & 7. 4 & 12.8 & 13.9 & 8.6 & I 16.3 & 6.8 \\
\hline & 試料 3 & 6.6 & 12. 3 & 10.6 & 6.2 & I 14.3 & 5. 3 \\
\hline \multirow{3}{*}{ T S H } & 試料 1 & 8.6 & 9. 9 & 12. 3 & 16.4 & 12. 0 & 11.6 \\
\hline & 試料 2 & 7. 0 & 8.2 & 8.6 & 8.6 & 9. 0 & 10.9 \\
\hline & 試料 3 & 6.8 & 10. 2 & 7. 9 & 8.4 & 11.9 & 8. 0 \\
\hline \multirow{3}{*}{$\mathrm{T}_{3}$} & 試料 1 & 9. 0 & 9. 7 & 7. 9 & 9.0 & 9. 2 & 8. 9 \\
\hline & 試料 2 & 5. 6 & 6.3 & 6. 3 & 6.8 & 7. 2 & 4. 5 \\
\hline & 試料 3 & 6.5 & 7. 1 & 5.8 & 6.1 & 7. 1 & 5. 2 \\
\hline \multirow{3}{*}{ Free $\mathrm{T}_{3}$} & 試料 1 & 9.7 & 14.0 & 11.3 & 14. 7 & 10.5 & 6.7 \\
\hline & 試料 2 & 6.7 & 6.2 & 7. 0 & 6.6 & 4. 9 & 5.6 \\
\hline & 試料 3 & 7. 7 & 7. 4 & 8. 3 & 7. 5 & 6.1 & 5.3 \\
\hline \multirow{3}{*}{$\mathrm{T}_{1}$} & 試料 1 & 10.8 & 13. 1 & 11.1 & 8.7 & 8. 7 & 8.2 \\
\hline & 試料 2 & 5.8 & 7. 5 & 8. 2 & 8. 6 & 5.1 & 6.0 \\
\hline & 試料 3 & 6.7 & 7. 1 & 5.4 & 9.1 & 6.7 & 5. 0 \\
\hline \multirow{3}{*}{ Free $\mathrm{T}_{1}$} & 試料 1 & 12.9 & 17. 9 & 12.8 & 8.8 & 11.3 & 7. 6 \\
\hline & 試料 2 & 8. 1 & 9. 4 & 7. 4 & 7. 7 & 3. 5 & 7. 2 \\
\hline & 試料 3 & 7. 9 & 12. 0 & 6.0 & 9. 9 & 6. 3 & 10. 6 \\
\hline \multirow{3}{*}{ T B G } & 試料 1 & 5. 9 & 5.8 & 4. 9 & 6. 3 & 6. 5 & 4. 6 \\
\hline & 試料 2 & 5.4 & 4. 9 & 6.1 & 7. 3 & 6.6 & 3. 7 \\
\hline & 試料 3 & 7. 2 & 7. 2 & 5.5 & 8. 0 & 4. 7 & 6.1 \\
\hline \multirow{3}{*}{ |カルシトニン } & 試料 1 & 25.5 & 34.4 & 25.2 & 18.1 & 16. 0 & 25.2 \\
\hline & 試料 2 & 22.1 & 19. 3 & 11.4 & 13.5 & 10.6 & 12.0 \\
\hline & 試料 3 & 26.6 & 17. 5 & 11.5 & 14.5 & 11.6 & 12.3 \\
\hline \multirow{3}{*}{ インスリン } & 試料 1 & 8.5 & 7. 2 & 8.7 & 7. 4 & 5.5 & 8.5 \\
\hline & 試料 2 & 6.3 & 6. 5 & 6.5 & 6.0 & 3. 8 & 5.3 \\
\hline & 試料 3 & 6.5 & 6.5 & 5.9 & 6.7 & 4. 6 & 4. 3 \\
\hline
\end{tabular}


（続き）

\begin{tabular}{|c|c|c|c|c|c|c|c|}
\hline 項 & & 第15回 & 第16回 & 第17回 & 第18回 & 第19回 & 第20回 \\
\hline \multirow{3}{*}{ C-ペプチド } & 試料 1 & 12.8 & 12.5 & 12.7 & 13.2 & 8.8 & 6.2 \\
\hline & 試料 2 & 8.9 & 11.6 & 10.1 & 7. 1 & 5.9 & 6.7 \\
\hline & 試料 3 & 13.8 & 10. 6 & 9.2 & 14.3 & 7.8 & 7. 3 \\
\hline \multirow{3}{*}{ グルカゴン } & 試料 1 & 12. 2 & 20.3 & 7.7 & 19. 4 & 12.8 & 13. 0 \\
\hline & 試料 2 & 9.9 & 21.5 & 7. 9 & 20.3 & 11.4 & 11.9 \\
\hline & 試料 3 & 10.1 & 9. 4 & 9.5 & 21.8 & 10.4 & 8.8 \\
\hline \multirow{3}{*}{ ガストリン } & 試料 1 & 15.8 & 10.6 & 12. 2 & 11.3 & 14.0 & 15.7 \\
\hline & 試料 2 & 11.7 & 9.3 & 7. 0 & 7. 2 & 7.9 & 6.4 \\
\hline & 試料 3 & 11.8 & 6.6 & 7. 1 & 10. 2 & 5.8 & 7. 6 \\
\hline \multirow{3}{*}{ テストステロン } & 試料 1 & 14.1 & 15.9 & 13.1 & 20.1 & 10.5 & 15.5 \\
\hline & 試料 2 & 13.5 & 12. 3 & 5.2 & 17. 6 & 16.6 & 4.7 \\
\hline & 試料 3 & 17. 9 & 8. 9 & 14.0 & 17.5 & 7. 3 & 11.3 \\
\hline \multirow{3}{*}{$\begin{array}{l}\text { Free } \\
\text { テストステロン }\end{array}$} & 試料 1 & 11.8 & 8. 6 & 34.7 & 15. 0 & 17.1 & 16.8 \\
\hline & 試料 2 & 6.3 & 10.1 & 7. 1 & 5.4 & 6.7 & 7.8 \\
\hline & 試料 3 & 9.1 & 5.8 & 5.5 & 8.0 & 6.5 & 3. 5 \\
\hline \multirow{3}{*}{ エストラジオール } & 試料 1 & 19. 2 & 15.6 & 19. 9 & 13. 9 & 29.5 & 17. 4 \\
\hline & 試料 2 & 15.4 & 10. 4 & 7. 6 & 10.6 & 9.7 & 12.8 \\
\hline & 試料 3 & 9. 6 & 8.0 & 7. 2 & 7. 4 & 13. 0 & 9.7 \\
\hline \multirow{3}{*}{ プロゲステロン } & 試料 1 & 12. 3 & 9.9 & 11.4 & 9.0 & 11.7 & 6.8 \\
\hline & 試料 2 & 6.5 & 6.4 & 9.5 & 7.5 & 6.0 & 4. 9 \\
\hline & 試料 3 & 8.3 & 6.3 & 7. 3 & 8.1 & 6.0 & 6.6 \\
\hline \multirow{3}{*}{$\beta \mathrm{HC} \mathrm{G} \mathrm{I}$} & 試料 1 & - & - & - & - & & - \\
\hline & 試料 2 & - & - & 25.1 & 19. 6 & 23.3 & 10.8 \\
\hline & 試料 3 & - & - & 11.5 & 9. 4 & 4. 4 & 4. 9 \\
\hline \multirow{3}{*}{ 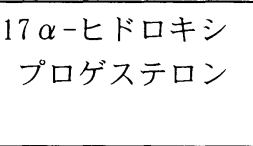 } & 試料 1 & 18. 0 & 4. 9 & 16. 0 & 13.5 & 71.9 & - \\
\hline & 試料 2 & 14.6 & 8. 0 & 5.8 & 10. 2 & 2. 3 & 27. 4 \\
\hline & 試料 3 & 9. 3 & 8. 2 & 8. 3 & 8.9 & 10.1 & 23.8 \\
\hline \multirow{3}{*}{ アルドステロン } & 試料 1 & 14.9 & 12.0 & 9.9 & 11.2 & 10.2 & 10.6 \\
\hline & 試料 2 & 9.6 & 9.9 & 9.4 & 10.7 & 7. 7 & 9.3 \\
\hline & 試料 3 & 10. 5 & 8.1 & 9.1 & 10.9 & 7. 9 & 8.1 \\
\hline \multirow{3}{*}{ コルチゾール } & 試料 1 & 12.1 & 11.5 & 12.6 & 12.6 & 10.1 & 8.5 \\
\hline & 試料 2 & 8.2 & 7.8 & 10. 2 & 11.9 & 5. 0 & 7.7 \\
\hline & 試料 3 & 7. 2 & 8.7 & 14.1 & 13.2 & 6.3 & 8.5 \\
\hline \multirow{3}{*}{ D HE A-S } & 試料 1 & 16.4 & 9.7 & 14.5 & 11.6 & 10.7 & 10.9 \\
\hline & 試料 2 & 6.5 & 10.2 & 8.1 & 8. 0 & 9.8 & 5.5 \\
\hline & 試料 3 & 5.8 & 16.1 & 23.0 & 9. 0 & 4. 0 & 3. 7 \\
\hline \multirow{3}{*}{ レニン定量 } & 試料 1 & 4.0 & 7. 4 & 6.6 & 7.1 & 4.6 & 5.4 \\
\hline & 試料 2 & 6.5 & 6.9 & 6.9 & 3.7 & 5.2 & 6. 2 \\
\hline & 試料 3 & 20.4 & 8. 9 & 6.5 & 4. 4 & 3.1 & 7. 8 \\
\hline
\end{tabular}


(続き)

\begin{tabular}{|c|c|c|c|c|c|c|c|}
\hline 項 & 目 & 第15回 & 第16回 & 第17回 & 第18回 & 第19回 & 第20回 \\
\hline \multirow{3}{*}{ I g E } & 試料 1 & 9.3 & 12.1 & 9.6 & 5.7 & 7. 5 & 5.4 \\
\hline & 試料 2 & 10.3 & 14.0 & 9.8 & 7.0 & 8.1 & 5.5 \\
\hline & 試料 3 & 11.9 & 13.5 & 8. 0 & 10.5 & 6.9 & 7. 0 \\
\hline \multirow{3}{*}{ ジゴキシン } & 試料 1 & 11.2 & 11.6 & 18. 2 & 2. 8 & 8. 0 & 5.2 \\
\hline & 試料 2 & 3. 9 & 9.5 & 10.1 & 5.7 & - & 4.8 \\
\hline & 試料 3 & 3. 2 & 16. 0 & 10. 3 & 1.2 & 1.1 & 1. 2 \\
\hline \multirow{3}{*}{$\begin{array}{l}\alpha-\text {-フト } \\
\text { プロテイン }\end{array}$} & 試料 1 & - & 9.5 & 10.7 & 8.5 & 6.7 & 7.7 \\
\hline & 試料 2 & - & 8.9 & 10.1 & 7. 1 & 6.7 & 7. 2 \\
\hline & 試料 3 & - & 10.7 & 11.1 & 7. 9 & 8.7 & 9.2 \\
\hline \multirow[t]{2}{*}{ CEA } & 試料 1 & 11.5 & 21.0 & 13.7 & 9.9 & 9.8 & 12.7 \\
\hline & 試料 2 & 6.9 & 11.6 & 6.4 & 7. 2 & 5.5 & 9.1 \\
\hline \multirow[t]{2}{*}{ TPA } & 試料 1 & 15.8 & 12.9 & 12. 2 & 13. 6 & 7. 1 & 12.5 \\
\hline & 試料 2 & - & - & - & - & - & - \\
\hline \multirow[t]{2}{*}{ CA 125} & 試料 1 & 81 & 7. 9 & 6.7 & 9.1 & 7. 6 & 5.8 \\
\hline & 試料 2 & 7. 1 & 7. 0 & 6.6 & 6.6 & 6.8 & 5.8 \\
\hline \multirow[t]{2}{*}{ CA $19-9$} & 試料 1 & 18.0 & 14.3 & 18.2 & 16.6 & 11.4 & 13.2 \\
\hline & 試料 2 & 13.4 & 15.0 & 12.3 & 11.0 & 9.1 & 9.7 \\
\hline \multirow[t]{2}{*}{ CA $15-3$} & 試料 1 & 12.4 & 14.2 & 15.0 & 10.6 & 12.5 & 9.9 \\
\hline & 試料 2 & 8.4 & 10.1 & 10.8 & 10.8 & 9.4 & 9.1 \\
\hline \multirow[t]{2}{*}{ PAP } & 試料 1 & 9.9 & 15.8 & 8.4 & 8.8 & 4.8 & 4.8 \\
\hline & 試料 2 & 16.6 & 23.0 & 13.6 & 13.7 & 21.6 & 13. 6 \\
\hline \multirow[t]{2}{*}{$P A(P S A)$} & 試料 1 & 11.5 & 8.1 & 9.6 & 9.5 & 9.9 & 12.3 \\
\hline & 試料 2 & 14.7 & 21.0 & 4. 1 & 8. 3 & 7. 2 & 6.1 \\
\hline \multirow{2}{*}{ 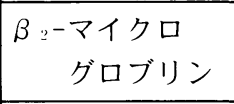 } & 試料 1 & 6.9 & 20.4 & 7. 4 & 11.8 & 9.0 & 7. 0 \\
\hline & 試料 2 & 7. 2 & 10. 6 & 5.9 & 7. 0 & 6.2 & 5.3 \\
\hline \multirow[t]{2}{*}{ フェリチン } & 試料 1 & 25.5 & 26.1 & 21.9 & 10.4 & 5.6 & 17.4 \\
\hline & 試料 2 & 13. 9 & 13. 3 & 9.6 & 13. 5 & 6.5 & 10. 9 \\
\hline \multirow[t]{2}{*}{ NSE } & 試料 1 & - & - & - & - & - & 11.6 \\
\hline & 試料 2 & - & - & - & - & - & 8.3 \\
\hline
\end{tabular}


表 9.2 キット内変動係数（Within kit Variation CV (\%)) の推移 (non-i sotopic法による系)

\begin{tabular}{|c|c|c|c|c|c|c|c|}
\hline 項 & 目 & 第15回 & 第16回 & 第17回 & 第18回 & 第19回 & 第20回 \\
\hline \multirow{3}{*}{ GH } & 試料 1 & 3. 3 & 4. 1 & 8. 1 & - & 2. 0 & 5. 9 \\
\hline & 試料 2 & 3. 7 & 5.8 & 5. 2 & 3. 8 & 6.8 & 3. 7 \\
\hline & 試料 3 & 4.6 & 1. 3 & 0.9 & 0.7 & 8.1 & 3. 7 \\
\hline \multirow{3}{*}{ F S H } & 試料 1 & 7.8 & 8.5 & 5. 2 & 7. 4 & 6.9 & 7. 2 \\
\hline & 試料 2 & 6.2 & 6.5 & 4. 1 & 7. 2 & 6.4 & 5. 3 \\
\hline & 試料 3 & 6.0 & 7. 8 & 5. 0 & 5. 6 & 7. 4 & 5.5 \\
\hline \multirow{3}{*}{$\mathrm{L} \mathrm{H}$} & 試料 1 & 8. 3 & 8.5 & 5.0 & 8. 3 & 53.4 & 8.8 \\
\hline & 試料 2 & 5.5 & 6.6 & 11.0 & 6.8 & 10.0 & 7. 9 \\
\hline & 試料 3 & 6.5 & 7. 4 & 8.8 & 8.7 & 10.6 & 8.2 \\
\hline \multirow{3}{*}{ プロラクチン } & 試料 1 & 8. 9 & 21.2 & 15. 9 & 5. 7 & 10.1 & 6.7 \\
\hline & 試料 2 & 7. 8 & 16. 0 & 15.6 & 5. 7 & 7. 7 & 6.4 \\
\hline & 試料 3 & 7. 9 & 14.6 & 14.8 & 6.5 & 7. 7 & 6.5 \\
\hline \multirow{3}{*}{ T S H } & 試料 1 & 10. 0 & 7. 6 & 6.1 & 11.7 & 5.5 & 6.4 \\
\hline & 試料 2 & 6.8 & 6.4 & 8. 9 & 6. 3 & 4. 6 & 4. 2 \\
\hline & 試料 3 & 7. 5 & 6.2 & 7. 6 & 7.8 & 4. 6 & 5.2 \\
\hline \multirow{3}{*}{$\mathrm{T}_{3}$} & 試料 1 & 11.9 & 13.2 & 11.2 & 9. 6 & 8. 5 & 7. 7 \\
\hline & 試料 2 & 8.1 & 6.3 & 6.7 & 6. 3 & 7. 6 & 4. 3 \\
\hline & 試料 3 & 7. 6 & 7. 0 & 5.5 & 4. 8 & 5.4 & 2. 5 \\
\hline \multirow{3}{*}{ Free $\mathrm{T}_{3}$} & 試料 1 & 11.5 & 12.7 & 9.4 & 7. 4 & 11.3 & 7. 3 \\
\hline & 試料 2 & 6.8 & 4. 9 & 7. 7 & 4. 0 & 3. 3 & 7. 7 \\
\hline & 試料 3 & 7. 1 & 5.1 & 5. 9 & 4. 5 & 3. 6 & 6.7 \\
\hline \multirow{3}{*}{$\mathrm{T}_{4}$} & 試料 1 & 9.8 & 19.7 & 8.7 & 9. 6 & 7. 7 & 7.8 \\
\hline & 試料 2 & 8. 2 & 4. 4 & 4. 4 & 5.5 & 4. 8 & 3.9 \\
\hline & 試料 3 & 7. 9 & 4. 0 & 4.7 & 5.1 & 3. 9 & 3.1 \\
\hline \multirow{3}{*}{ Free $T_{1}$} & 試料 1 & 26.3 & 12.7 & 12.7 & 13.7 & 11.1 & 8.4 \\
\hline & 試料 2 & 8.6 & 5. 3 & 7. 4 & 10.9 & 6.8 & 6.2 \\
\hline & 試料 3 & 12.4 & 7.9 & 8.8 & 10.2 & 5.6 & 7.6 \\
\hline \multirow{3}{*}{ インスリン } & 試料 1 & 10.4 & 9. 2 & 15.1 & 9.8 & 7. 9 & 6.6 \\
\hline & 試料 2 & 7. 7 & 7. 3 & 11.2 & 7. 5 & 5.4 & 6.9 \\
\hline & 試料 3 & 7. 0 & 4. 6 & 9.4 & 9.7 & 5.1 & 7.6 \\
\hline \multirow{3}{*}{ C-ペプチド } & 試料 1 & - & - & 4. 0 & 4. 0 & 9.6 & 2.6 \\
\hline & 試料 2 & - & - & 3. 3 & 3. 9 & 4. 4 & 3. 4 \\
\hline & 試料 3 & - & - & 3. 0 & 3.5 & 4. 9 & 6.0 \\
\hline \multirow{3}{*}{ テストステロン } & 試料 1 & - & - & 21.8 & 19. 3 & 9.1 & 8.2 \\
\hline & 試料 2 & - & - & 4. 3 & 3.7 & 6.2 & 4.2 \\
\hline & 試料 3 & - & - & 8.6 & 5.8 & 5.3 & 12.3 \\
\hline \multirow{3}{*}{ エストラジオール } & 試料 1 & 5. 7 & 10. 4 & 13. 3 & 13.8 & 13. 6 & 9. 6 \\
\hline & 試料 2 & 2. 0 & 4. 0 & 6.9 & 9.8 & 8.2 & 7. 0 \\
\hline & 試料 3 & 6.1 & 9.3 & 11.3 & 12.1 & 9. 6 & 9.9 \\
\hline
\end{tabular}


（続き）

\begin{tabular}{|c|c|c|c|c|c|c|c|}
\hline \multicolumn{2}{|c|}{ 目 } & 第15回 & 第16回 & 第17回 & 第18回 & 第19回 & 第20回 \\
\hline \multirow{3}{*}{ プロゲステロン } & 試料 1 & - & 9. 3 & 27.1 & 13. 2 & 12. 7 & 10. 1 \\
\hline & 試料 2 & - & 2. 8 & 11. 5 & 10.5 & 12.8 & 12. 1 \\
\hline & 試料 3 & - & 3.9 & 10.9 & 13. 4 & 12.6 & 8.4 \\
\hline \multirow{6}{*}{$\beta \mathrm{HCG}$} & 試料 1 & - & - & I - & I - & I - & I 12.4 \\
\hline & & - & - & II 6.8 & II 6.4 & II 3.0 & II 7.5 \\
\hline & 試料 2 & - & - & I - & I - & & $\mathrm{I} \quad 7.5$ \\
\hline & & - & - & II 6.0 & II 5.7 & II 6.8 & II 5.1 \\
\hline & 試料 3 & - & - & $\bar{I}-$ & $\bar{I}-$ & $\bar{I}-$ & $\mathrm{I} \quad 8.9$ \\
\hline & & - & - & II $\quad 4.3$ & II 5.9 & II 8.8 & II 5.5 \\
\hline \multirow{3}{*}{ コルチゾール } & 試料 1 & 15.5 & 16.6 & 16.6 & 17. 1 & 17.7 & 10.1 \\
\hline & 試料 2 & 10.4 & 6.4 & 6.4 & 10. 7 & 4. 9 & 5.1 \\
\hline & 試料 3 & 8. 3 & 5.8 & 5.8 & 9.0 & 6.6 & 6.0 \\
\hline \multirow{3}{*}{ I g E } & 試料 1 & 9.2 & 5.9 & 10. 3 & 6. 2 & 6.4 & 7. 7 \\
\hline & 試料 2 & 9.8 & 6.1 & 8. 9 & 5.8 & 4. 2 & 5. 7 \\
\hline & 試料 3 & 9.5 & 7. 6 & 8.5 & 9.0 & 5. 2 & 7. 6 \\
\hline \multirow{3}{*}{ ジゴキシン } & 試料 1 & 14. 4 & 12.7 & 18.7 & 16. 3 & 14.7 & 9.8 \\
\hline & 試料 2 & 6.1 & 5.7 & 6.9 & 5.3 & 6.5 & 4. 6 \\
\hline & 試料 3 & 3. 3 & 4. 1 & 5.8 & 5.1 & 4. 2 & 4. 5 \\
\hline \multirow{3}{*}{$\begin{array}{l}\alpha-\text { フ } \\
\text { プロテイン }\end{array}$} & 試料 1 & - & 8. 0 & 8.1 & 10. 8 & 5.9 & 5.7 \\
\hline & 試料 2 & - & 7. 3 & 7. 3 & 11.5 & 6.7 & 6.9 \\
\hline & 試料 3 & - & 7. 3 & 8. 2 & 11.6 & 8.6 & 8. 2 \\
\hline \multirow[t]{2}{*}{$C E A$} & 試料 1 & 11.7 & 12.4 & 9.0 & 14.9 & 7. 3 & 9. 3 \\
\hline & 試料 2 & 10.0 & 10.7 & 5.8 & 12.7 & 5.7 & 8.1 \\
\hline \multirow[t]{2}{*}{ C A 125} & 試料 1 & 123 & 9.7 & 10.3 & 8.6 & 7.0 & 6.7 \\
\hline & 試料 2 & 8. 9 & 9.7 & 9.5 & 8. 3 & 6.3 & 5.6 \\
\hline \multirow[t]{2}{*}{ C A $19-9$} & 試料 1 & 8.4 & 15.1 & 16.4 & 9.3 & 11.3 & 9.8 \\
\hline & 試料 2 & 6.7 & 12.3 & 14. 2 & 6. 9 & 7. 2 & 5.8 \\
\hline \multirow[t]{2}{*}{$C A 15-3$} & 試料 1 & 11.1 & 8.2 & 12.3 & 14.6 & 8.7 & 13.9 \\
\hline & 試料 2 & 4. 2 & 6.6 & 10. 6 & 12. 9 & 7. 1 & 8.5 \\
\hline \multirow[t]{2}{*}{ PAP } & 試料 1 & 8. 1 & 10.4 & 5. 0 & 5. 9 & 4. 4 & 5. 1 \\
\hline & 試料 2 & 11. 4 & 11.0 & 8.8 & 14. 6 & 11.5 & 14.2 \\
\hline \multirow[t]{2}{*}{$P A(P S A)$} & 試料 1 & 10.3 & 7. 5 & 9.8 & 11.3 & 8.0 & 10.1 \\
\hline & 試料 2 & 10.6 & 6.4 & 9.4 & 6.6 & 11.1 & 12.6 \\
\hline \multirow{2}{*}{$\begin{array}{r}\beta \ldots \text {-マイクロ } \\
\text { グロブリン }\end{array}$} & 試料 1 & 11.3 & 9. 4 & 16.9 & 12.0 & 8.6 & 13.6 \\
\hline & 試料 2 & 12. 3 & 9.5 & 16.5 & 10.8 & 7.5 & 6.9 \\
\hline \multirow[t]{2}{*}{ フェリチン } & 試料 1 & 41.9 & 23.6 & 18.8 & 11.7 & 7. 0 & 13.5 \\
\hline & 試料 2 & 13.9 & 9.0 & 8.4 & 9.9 & 6.4 & 6.5 \\
\hline \multirow[t]{2}{*}{ NSE } & 試料 1 & - & - & - & - & - & 5.4 \\
\hline & 試料 2 & - & - & - & - & - & 6.0 \\
\hline
\end{tabular}

注 $\beta \mathrm{HCG} \quad \mathrm{I}$ ：濃度単位が、 $\mathrm{ng} / \mathrm{ml}$ の系。

II : 濃度単位が、mIU/ml の系。 
表 9.3 キット内変動係数（Within kit Variation $\mathrm{CV}(\%)$ ) の推移 （i sotopic法およびnon-i sot opic法による系）

\begin{tabular}{|c|c|c|c|c|c|c|c|}
\hline 項 & 目 & 第15回 & 第16回 & 第17回 & 第18回 & 第19回 & 第20回 \\
\hline \multirow{3}{*}{ GH } & 試料 1 & 8. 0 & 7. 5 & 9.8 & 7. 9 & 6.4 & 7. 8 \\
\hline & 試料 2 & 7. 0 & 5.6 & 8.7 & 7.8 & 6.4 & 6.5 \\
\hline & 試料 3 & 7. 0 & 5.8 & 6.6 & 6.4 & 5.9 & 5.1 \\
\hline \multirow{3}{*}{ ソマトメジンC } & 試料 1 & 10.1 & 20.8 & 8.8 & 10.5 & 8.7 & 11.5 \\
\hline & 試料 2 & 8.8 & 13.7 & 7. 3 & 8.0 & 5.6 & 10.1 \\
\hline & 試料 3 & 9.4 & 19. 4 & 8.1 & 10.7 & 9.0 & 8.9 \\
\hline \multirow{3}{*}{$\mathrm{F} \mathrm{S} \mathrm{H}$} & 試料 1 & 7. 9 & 7.1 & 5.6 & 10. 0 & 5.7 & 6.3 \\
\hline & 試料 2 & 7. 8 & 6.0 & 5.0 & 7. 2 & 5.5 & 4. 8 \\
\hline & 試料 3 & 6.3 & 6.3 & 4. 6 & 5.0 & 6.6 & 5.3 \\
\hline \multirow{3}{*}{ L H } & 試料 1 & 9.0 & 8. 4 & 9.0 & 9.9 & 37.3 & 7. 7 \\
\hline & 試料 2 & 6.5 & 6.1 & 7.6 & 6.0 & 8.5 & 7. 1 \\
\hline & 試料 3 & 7. 7 & 6.7 & 8.5 & 8.3 & 8.6 & 7. 9 \\
\hline \multirow{3}{*}{ プロラクチン } & 試料 1 & 9.5 & 15. 2 & 13. 5 & 7. 4 & 14.9 & 6.1 \\
\hline & 試料 2 & 7.5 & 12.8 & 14.5 & 7. 6 & 12.6 & 6.6 \\
\hline & 試料 3 & 6.9 & 12.3 & 12. 2 & 6.3 & 11. 3 & 6.0 \\
\hline \multirow{3}{*}{$\mathrm{T} \mathrm{S} \mathrm{H}$} & 試料 1 & 9. 0( & 9.1 & 11.0 & 14.1 & 9.2 & 9.1 \\
\hline & 試料 2 & 7. 0( & 7.5 & 9.4 & 6.4 & 7. 0 & 7. 4 \\
\hline & 試料 3 & 7. 0( & 8. 9 & 9.4 & 7.5 & 8. 9 & 6.4 \\
\hline \multirow{3}{*}{$\mathrm{T}_{3}$} & 試料 1 & 9.6 & 11.1 & 9.3 & 9.3 & 8.9 & 8.2 \\
\hline & 試料 2 & 6.4 & 6.3 & 6.5 & 6.1 & 5.5 & 4. 4 \\
\hline & 試料 3 & 6.9 & 7. 4 & 5.7 & 5.4 & 6.2 & 3. 6 \\
\hline \multirow{3}{*}{ Free $\mathrm{T}_{3}$} & 試料 1 & 10.1 & 13.5 & 10.5 & 11.3 & 11.0 & 7. 1 \\
\hline & 試料 2 & 6.7 & 5. 7 & 7. 3 & 5.3 & 4. 0 & 7. 1 \\
\hline & 試料 3 & 7. 6 & 6.6 & 7. 5 & 6.2 & 5.0 & 6.1 \\
\hline \multirow{3}{*}{$\mathrm{T}_{1}$} & 試料 1 & 10.5 & 12. 3 & 10. 2 & 9.2 & 8.2 & 8.0 \\
\hline & 試料 2 & 6.5 & 6.5 & 6.9 & 7. 1 & 4. 6 & 4. 7 \\
\hline & 試料 3 & 7. 1 & 6.1 & 5. 2 & 7. 2 & 5.2 & 3.9 \\
\hline \multirow{3}{*}{ Free $\mathrm{T}$} & 試料 1 & 16. 9 & 15.9 & 12.8 & 11.7 & 11. 2 & 8.1 \\
\hline & 試料 2 & 8. 2 & 8. 1 & 7. 4 & 9.6 & 5.5 & 6.6 \\
\hline & 試料 3 & 9.2 & 10.5 & 7. 4 & 8.8 & 6.0 & 9.3 \\
\hline \multirow{3}{*}{ T B G } & 試料 1 & 6.3 & 5.8 & 5.1 & 6.6 & 6.5 & 4. 6 \\
\hline & 試料 2 & 5.5 & 5.0 & 6.3 & 7. 9 & 6.6 & 3.8 \\
\hline & 試料 3 & 7.1 & 7. 1 & 6.3 & 7.8 & 4.8 & 6.1 \\
\hline \multirow{3}{*}{ カルシトニン } & 試料 1 & 25.5 & 34.4 & 25.2 & 18.1 & 16.0 & 25.2 \\
\hline & 試料 2 & 22.1 & 19. 3 & 11. 4 & 13.5 & 10.6 & 12.0 \\
\hline & 試料 3 & 26.6 & 17.5 & 11.5 & 14.5 & 11.6 & 12.3 \\
\hline \multirow{3}{*}{ インスリン } & 試料 1 & 8.8 & 7.5 & 10.0 & 8.0 & 6.2 & 7.9 \\
\hline & 試料 2 & 6.5 & 6.6 & 7. 4 & 6.4 & 4.3 & 5.9 \\
\hline & 試料 3 & 6.5 & 6.8 & 6.6 & 7. 4 & 4. 7 & 5.5 \\
\hline
\end{tabular}


（続き）

\begin{tabular}{|c|c|c|c|c|c|c|c|}
\hline 項 & & 第15回 & 第16回 & 第17回 & 第18回 & 第19回 & 第20回 \\
\hline \multirow{3}{*}{ Cーペプチド } & 試料 1 & 12.8 & 12.5 & 12.4 & 12.6 & 8. 9 & 5.8 \\
\hline & 試料 2 & 8. 9 & 11.6 & 9. 8 & 6.9 & 5.7 & 6.3 \\
\hline & 試料 3 & 13. 8 & 10.6 & 9.0 & 13. 8 & 7. 5 & 7.1 \\
\hline \multirow{3}{*}{ グルカゴン } & 試料 1 & 12. 2 & 20.3 & 7. 7 & 19. 4 & 12.8 & 13. 0 \\
\hline & 試料 2 & 9. 9 & 21.5 & 7. 9 & 20.3 & 11.4 & 11.9 \\
\hline & 試料 3 & 10. 1 & 9.4 & 9. 5 & 21.8 & 10.4 & 8.8 \\
\hline \multirow{3}{*}{ ガストリン } & 試料 1 & 15.8 & 10.6 & 12.2 & 11.3 & 14.0 & 15.7 \\
\hline & 試料 2 & 11.7 & 9. 3 & 7. 0 & 7.2 & 7. 9 & 6.4 \\
\hline & 試料 3 & 11.8 & 6.6 & 7. 1 & 9.5 & 5.8 & 7. 6 \\
\hline \multirow{3}{*}{ テストステロン } & 試料 1 & 14.1 & 15.9 & 13. 6 & 20.3 & 10.3 & 14.6 \\
\hline & 試料 2 & 13. 5 & 12. 3 & 5.1 & 15. 1 & 14. 3 & 4. 4 \\
\hline & 試料 3 & 17. 9 & 8. 9 & 13. 6 & 15.4 & 6.8 & 11.7 \\
\hline \multirow{3}{*}{$\begin{array}{l}\text { Free } \\
\text { テストステロン }\end{array}$} & 試料 1 & 11.8 & 8.6 & 34.7 & 15.0 & 17.1 & 16.8 \\
\hline & 試料 2 & 6.3 & 10.1 & 7. 1 & 5.4 & 6.7 & 7. 8 \\
\hline & 試料 3 & 9.1 & 5.8 & 5.5 & 8. 0 & 6.5 & 3.5 \\
\hline \multirow{3}{*}{ エストラジオール } & 試料 1 & 16.1 & 13.1 & 16.4 & 13.9 & 19. 7 & 11.6 \\
\hline & 試料 2 & 14. 0 & 8. 5 & 7. 4 & 11.6 & 9.1 & 10.3 \\
\hline & 試料 3 & 9. 5 & 8. 2 & 8. 2 & 13. 0 & 12.0 & 9.8 \\
\hline \multirow{3}{*}{ プロゲステロン } & 試料 1 & 12. 4 & 9.7 & 16. 9 & 11.1 & 12.1 & 8.4 \\
\hline & 試料 2 & 6.5 & 6.2 & 9. 9 & 8. 6 & 9. 3 & 9.0 \\
\hline & 試料 3 & 8. 3 & 6.1 & 8. 1 & 10. 0 & 9.1 & 7. 4 \\
\hline \multirow{6}{*}{$\beta \mathrm{HC} \mathrm{G}$} & 試料 1 & - & - & I - & I - & I - & I 10.7 \\
\hline & & & & II 6.8 & II 6.4 & II 3.0 & II 7.5 \\
\hline & 試料 2 & - & - & I 25.1 & I 11.2 & I 23.3 & I 9.9 \\
\hline & & & & II 6.0 & II 5.7 & II 6.8 & II 5.1 \\
\hline & 試料 3 & - & - & I 11.5 & I 9.4 & I 4.4 & I 6.1 \\
\hline & & & & II 4.3 & II 5.8 & II 8.8 & II 5.5 \\
\hline \multirow{3}{*}{$\begin{array}{c}17 \alpha \text {-ヒドロキシ } \\
\text { プロゲステロン }\end{array}$} & 試料 1 & 13.7 & 3.5 & 16.0 & 13.5 & 52.1 & - \\
\hline & 試料 2 & 14.4 & 8. 2 & 5.9 & 10. 7 & 2. 6 & 27.4 \\
\hline & 試料 3 & 9.6 & 8.5 & 8. 5 & 9.5 & 10.8 & 23.8 \\
\hline \multirow{3}{*}{ アルドステロン } & 試料 1 & 14. 9 & 12.0 & 9. 9 & 11.2 & 10. 2 & 10. 6 \\
\hline & 試料 2 & 9. 6 & 9.9 & 9.4 & 10.7 & 7.7 & 9.3 \\
\hline & 試料 3 & 10.5 & 8.1 & 9.1 & 10.9 & 7. 9 & 8.1 \\
\hline \multirow{3}{*}{ コルチゾール } & 試料 1 & 12.7 & 12.5 & 13. 9 & 13. 3 & 12.2 & 9.1 \\
\hline & 試料 2 & 8.7 & 7. 4 & 10.3 & 12. 7 & 5.0 & 6.8 \\
\hline & 試料 3 & 7. 4 & 8. 1 & 12.8 & 13.2 & 6.4 & 7. 6 \\
\hline \multirow{3}{*}{ D HE A-S } & 試料 1 & 16. 4 & 9.7 & 14.5 & 11.6 & 10.8 & 10.9 \\
\hline & 試料 2 & 6.5 & 10. 2 & 8.1 & 8. 1 & 9.8 & 5.5 \\
\hline & 試料 3 & 5.8 & 16.1 & 23.0 & 9.0 & 4. 0 & 3.7 \\
\hline
\end{tabular}


(続き)

\begin{tabular}{|c|c|c|c|c|c|c|c|}
\hline 項 & 目 & 第15回 & 第16回 & 第17回 & 第18回 & 第19回 & 第20回 \\
\hline \multirow{3}{*}{ レニン定量 } & 試料 1 & 4. 0 & 7. 4 & 6.6 & 7. 1 & 4. 6 & 5.4 \\
\hline & 試料 2 & 6.5 & 6.9 & 6.9 & 3.7 & 5.2 & 6.2 \\
\hline & 試料 3 & 20.4 & 8. 9 & 6.5 & 4. 4 & 3.1 & 7. 8 \\
\hline \multirow{3}{*}{ I g E } & 試料 1 & 9. 3 & 10.5 & 10.1 & 6.0 & 6.9 & 6.9 \\
\hline & 試料 2 & 10.1 & 11.9 & 9. 5 & 6.4 & 6.3 & 5.6 \\
\hline & 試料 3 & 11.2 & 11.7 & 8.2 & 9.7 & 6.1 & 7. 4 \\
\hline \multirow{3}{*}{ ジゴキシン } & 試料 1 & 14. 2 & 12.7 & 18. 7 & 16.1 & 14.6 & 9.7 \\
\hline & 試料 2 & 5.8 & 6.2 & 7. 0 & 5. 3 & 6.4 & 4. 6 \\
\hline & 試料 3 & 3.3 & 6.5 & 6.0 & 5. 0 & 4. 1 & 4. 4 \\
\hline \multirow{3}{*}{$\begin{array}{l}\alpha-\text { フェト } \\
\text { プロテイン }\end{array}$} & 試料 1 & - & 9.0 & 9.7 & 9.7 & 6.3 & 6.5 \\
\hline & 試料 2 & - & 8. 3 & 8.9 & 9.6 & 6.7 & 7. 0 \\
\hline & 試料 3 & - & 9.3 & 9. 8 & 10.0 & 8.6 & 8.6 \\
\hline \multirow[t]{2}{*}{ C E A } & 試料 1 & 12.0 & 16.1 & 10.8 & 14.8 & 8.0 & 10.3 \\
\hline & 試料 2 & 9.3 & 11.2 & 6.4 & 12. 4 & 10.2 & 9. 0 \\
\hline \multirow[t]{2}{*}{ TPA } & 試料 1 & 15.8 & 12.9 & 12. 2 & 13. 6 & 7. 2 & 12.3 \\
\hline & 試料 2 & - & - & - & - & - & - \\
\hline \multirow[t]{2}{*}{ C A 125} & 試料 1 & 8.6 & 8.2 & 7.5 & 9.0 & 7.5 & 6.2 \\
\hline & 試料 2 & 7. 4 & 7. 6 & 7. 3 & 7.1 & 6.7 & 5.3 \\
\hline \multirow[t]{2}{*}{ C A $19-9$} & 試料 1 & 14.8 & 14.6 & 17.7 & 14.1 & 11.3 & 11.7 \\
\hline & 試料 2 & 11.5 & 14.0 & 12.7 & 9. 4 & 8. 0 & 8.1 \\
\hline \multirow[t]{2}{*}{ C A $15-3$} & 試料 1 & 12. 2 & 13.8 & 14.6 & 11.7 & 11.6 & 11.1 \\
\hline & 試料 2 & 8.2 & 9.9 & 10.9 & 11.4 & 8.5 & 8.8 \\
\hline \multirow[t]{2}{*}{ P A P } & 試料 1 & 9.8 & 15. 4 & 8. 0 & 8.1 & 4.8 & 5.0 \\
\hline & 試料 2 & 15.9 & 21.9 & 13. 1 & 19.9 & 19. 2 & 14.1 \\
\hline \multirow[t]{2}{*}{$\mathrm{PA}(\mathrm{PSA})$} & 試料 1 & 10.7 & 7. 8 & 10. 1 & 11.2 & 8.5 & 10.5 \\
\hline & 試料 2 & 12.2 & 10.6 & 9.2 & 7.1 & 10.5 & 11.6 \\
\hline \multirow{2}{*}{$\begin{array}{c}\text { B } 2 \text {-マイクロ } \\
\text { グロブリン }\end{array}$} & 試料 1 & 8.1 & 18. 2 & 11.1 & 11.9 & 8.8 & 10.8 \\
\hline & 試料 2 & 8. 5 & 10.4 & 10. 1 & 8.6 & 6.8 & 6.2 \\
\hline \multirow[t]{2}{*}{ フェリチン } & 試料 1 & 33.4 & 24.6 & 20.1 & 11.2 & 6.6 & 14.5 \\
\hline & 試料 2 & 13. 8 & 11.3 & 9.0 & 11.4 & 6.4 & 7. 7 \\
\hline \multirow[t]{2}{*}{ NSE } & 試料 1 & - & - & - & - & - & 11.8 \\
\hline & 試料 2 & - & - & - & - & - & 8.3 \\
\hline
\end{tabular}

注 $\beta \mathrm{HCG} \quad \mathrm{I}$ ：濃度単位が、 $\mathrm{ng} / \mathrm{ml}$ の系。

II：濃度単位が、 $\mathrm{mIU} / \mathrm{ml}$ の系。 
表10. 1 キット間変動係数（Between kit Variation CV (\%)) の推移 （isotopic法による系）

\begin{tabular}{|c|c|c|c|c|c|c|c|}
\hline 項 & 目 & 第15回 & 第16回 & 第17回 & 第18回 & 第19回 & 第20回 \\
\hline \multirow{3}{*}{ GH } & 試料 1 & $12.9(5)$ & $13.7 \quad(5)$ & $25.3(5)$ & $16.2(5)$ & 20.5 (3) & 9. 1 (2) \\
\hline & 試料 2 & $13.5 \quad(5)$ & 14.0 (5) & $28.9(5)$ & $18.0(5)$ & 22.0 (3) & $12.5 \quad(2)$ \\
\hline & 試料 3 & $12.4 \quad(5)$ & 11.2（5） & 19.8 (5) & 19.8 (5) & $22.6 \quad(3)$ & 18. 5（2） \\
\hline \multirow{3}{*}{ ソマトメジンC } & 試料 1 & - & 36.3 (2) & 49.0 (2) & 45.1 (3) & 34.9 (3) & 20.8 (3) \\
\hline & 試料 2 & - & 40. 4（2) & 57.0 (2) & 57.8 (3) & $52.6(3)$ & 24.3 (3) \\
\hline & 試料 3 & - & $52.2(2)$ & 69.2 (2) & 89.8 (3) & 77.0 (3) & $39.4 \quad(3)$ \\
\hline \multirow{3}{*}{ F S H } & 試料 1 & $17.5 \quad(7)$ & $17.8(6)$ & 15.0 (4) & $12.8(4)$ & 15.2 (3) & 26.0 (3) \\
\hline & 試料 2 & 16.1 (7) & 17. $2(6)$ & 16.6 (4) & $17.2(4)$ & $21.7(3)$ & 27.0 (3) \\
\hline & 試料 3 & 19.5 (7) & $22.2(6)$ & 23.8 (4) & 22.7 (4) & 29.3 (3) & $34.6 \quad(3)$ \\
\hline \multirow{3}{*}{$\mathrm{L} H$} & 試料 1 & $25.2(7)$ & $27.6(6)$ & $27.3(4)$ & 31.5 (4) & $35.1 \quad(3)$ & $43.6 \quad(3)$ \\
\hline & 試料 2 & 17. 0 (7) & $20.4 \quad(6)$ & 20.8 (4) & 24.3 (4) & 23.5 (3) & 22.2 (3) \\
\hline & 試料 3 & $18.1 \quad(7)$ & $24.5(6)$ & 21.1 (4) & $23.6 \quad(4)$ & $28.6 \quad(3)$ & 20.9 (3) \\
\hline \multirow{3}{*}{ プロラクチン } & 試料 1 & 56.6 (8) & $52.2(7)$ & $60.9(6)$ & $58.5(6)$ & $62.8 \quad(5)$ & $77.5(4)$ \\
\hline & 試料 2 & 55.2 (8) & $52.4(7)$ & $55.2(6)$ & $46.7 \quad(6)$ & 48. 2(5) & $77.6 \quad(4)$ \\
\hline & 試料 3 & $55.3(8)$ & $52.7(7)$ & $55.3(6)$ & $41.6 \quad(6)$ & 45.7 (5) & 74.7 (4) \\
\hline \multirow{3}{*}{ T S H } & 試料 1 & 14.0 (9) & 12. $8(9)$ & $11.1(7)$ & $16.4(6)$ & $11.8 \quad(5)$ & $10.9(6)$ \\
\hline & 試料 2 & 7. 1 (9) & 8. 7 (9) & $10.5(7)$ & $10.5(6)$ & 10.7 (5) & $10.4 （ 6)$ \\
\hline & 試料 3 & 7. $4 \quad(9)$ & 9. 2 (9) & 11.8 (7) & $10.3 \quad(6)$ & $10.5(5)$ & $10.6(6)$ \\
\hline \multirow{3}{*}{$\mathrm{T}_{3}$} & 試料 1 & 10. $9(11)$ & 8. $9(10)$ & 9. 9 (9) & 9. 0 (9) & $11.5(7)$ & 9. 1 (7) \\
\hline & 試料 2 & 6. 4(11) & 6. $7(10)$ & 9. 7 (9) & $11.9(9)$ & $14.0 \quad(7)$ & 9. 9 (7) \\
\hline & 試料 3 & 8. $5(11)$ & 7. $6(10)$ & $10.6(9)$ & $11.0(9)$ & $12.7(7)$ & $11.2(7)$ \\
\hline \multirow{3}{*}{ Free $\mathrm{T}_{3}$} & 試料 1 & $23.0 \quad(6)$ & $20.1 \quad(5)$ & $17.0 \quad(5)$ & 17.4 (4) & 8.3 (3) & $21.3(4)$ \\
\hline & 試料 2 & $21.1 \quad(6)$ & 19. $3(5)$ & 25.1 (5) & 28.9 (4) & $35.0 \quad(3)$ & $26.6 \quad(4)$ \\
\hline & 試料 3 & 24.2 (6) & $33.6 \quad(5)$ & 37.7 (5) & 39.0 (4) & 43.3 (3) & 37.3 (4) \\
\hline \multirow{3}{*}{$\mathrm{T}_{4}$} & 4 & 5. 7(10) & 10. $8 \quad(9)$ & 7. $3(10)$ & 3. $5(10)$ & 4. 6 (8) & $1.9(7)$ \\
\hline & 試料 2 & 3. 1(10) & 4. 0 (9) & 4. $1(10)$ & 5. $0(10)$ & 5. 7 (8) & 6. 2 (7) \\
\hline & 試料 3 & 5. $0(10)$ & 5. 9 (9) & 6. $0(10)$ & 6. $0(10)$ & $5.8 \quad(8)$ & 7. $6(7)$ \\
\hline \multirow{3}{*}{ Free $\mathrm{T}_{4}$} & 試料 1 & 33.9 (9) & $38.5 \quad(8)$ & $19.9(8)$ & $22.1(7)$ & $37.7(6)$ & $36.9(6)$ \\
\hline & 試料 2 & 23.4 (9) & $24.9(8)$ & $32.0(8)$ & 43.3 (7) & $50.0(6)$ & $43.8 \quad(6)$ \\
\hline & 試料 3 & $40.8 \quad(9)$ & 54.1 (8) & $68.8(8)$ & $41.2(6)$ & $50.0 \quad(6)$ & $47.0 \quad(5)$ \\
\hline \multirow{3}{*}{ T B G } & 試料 1 & 5.7 (3) & 3. 4 (3) & 7. 6 (3) & 6. 1 (2) & 11.0 (2) & $11.0 \quad(2)$ \\
\hline & 試料 2 & 7. 6 (3) & 6. 7 (3) & 9. 8 (3) & 8. 4 (2) & 11.8 (2) & 18. 1（2) \\
\hline & 試料 3 & 9. 5 (3) & $12.0 \quad(3)$ & $13.7(3)$ & 9. $6 \quad(2)$ & 15.6 (2) & 19. 2（2） \\
\hline \multirow{3}{*}{ カルシトニン } & 試料 1 & 49. 2 (4) & 51.5 (4) & 42.8 (4) & $46.6 \quad(4)$ & 40.9 (4) & $40.8 \quad(4)$ \\
\hline & 試料 2 & - & 8. 6 (4) & $5.7(4)$ & 16. 6 (4) & 16.5 (4) & 19.8 (4) \\
\hline & 試料 3 & - & 6.1 (4) & 14.6 (4) & 25.2 (4) & 23.9 (4) & $21.9 \quad(4)$ \\
\hline
\end{tabular}


(続き)

\begin{tabular}{|c|c|c|c|c|c|c|c|}
\hline 項 & 目 & 第15回 & 第16回 & 第17回 & 第18回 & 第19回 & 第20回 \\
\hline \multirow{3}{*}{ インスリン } & 試料 1 & $14.1(6)$ & $11.5(6)$ & $15.7(6)$ & $17.3(6)$ & 17. $2(6)$ & $16.9(6)$ \\
\hline & 試料 2 & $9.8(6)$ & 8. 1 (6) & $12.5(6)$ & $10.8(6)$ & $11.0(6)$ & $12.7(6)$ \\
\hline & 試料 3 & $10.2(6)$ & 9. $5(6)$ & $13.8(6)$ & $10.7(6)$ & $11.5(6)$ & $15.7(6)$ \\
\hline \multirow{3}{*}{ Cーペプチド } & 試料 1 & 5. 4(2) & $1.5(2)$ & - & 27.3 (2) & 20.7 (3) & $22.5 \quad(2)$ \\
\hline & 試料 2 & 18.2 (2) & 18.1 (2) & $27.9(2)$ & 32.4 (2) & $20.0 \quad(3)$ & 23.1 (2) \\
\hline & 試料 3 & $41.5 \quad(2)$ & $39.1 \quad(2)$ & $44.0 \quad(2)$ & $41.6 \quad(2)$ & 26. 2（3) & 28.9 (2) \\
\hline \multirow{3}{*}{ テストステロン } & 試料 1 & 30.8 (3) & $37.0 \quad(3)$ & 47.1 (3) & 33.4 (3) & 23.9 (3) & $31.5 \quad(3)$ \\
\hline & 試料 2 & 27.7 (3) & 20.5 (3) & 44.2 (3) & 35.8 (3) & 31.8 (3) & 21.1 (3) \\
\hline & 試料 3 & 47. 3 (3) & $37.4 \quad(3)$ & $68.3 \quad(3)$ & $50.5 \quad(3)$ & $23.6 \quad(3)$ & $34.6 \quad(3)$ \\
\hline \multirow{3}{*}{ エストラジオー) } & 試料 1 & 18.2 (4) & $14.3(4)$ & 4. 9 (4) & 39.2 (3) & $43.0 \quad(4)$ & $13.6 \quad(4)$ \\
\hline & ル試料 2 & $12.3(4)$ & 9.1 (4) & 41.1 (4) & 27.7 (3) & 29.0 (4) & 24.2 (4) \\
\hline & 試料 3 & 22.2 (4) & 32.8 (4) & $43.6 \quad(4)$ & 40.2 (3) & 35.8 (4) & 40.0 (4) \\
\hline \multirow{3}{*}{ プロゲステロン } & 試料 1 & $31.9(3)$ & $25.0 \quad(3)$ & 40.5 (3) & 45.8 (3) & 13.8 (3) & 37.8 (3) \\
\hline & 試料 2 & 26.5 (3) & $21.1 \quad(3)$ & 24.0 (3) & 30.3 (3) & 40.4 (3) & $30.0 \quad(3)$ \\
\hline & 試料 3 & 39. 2 (3) & $35.5 \quad(3)$ & $34.6 \quad(3)$ & $37.6 \quad(3)$ & 51.9 (3) & 42. 3 (3) \\
\hline \multirow{3}{*}{ アルドステロン } & 試料 1 & $25.6 \quad(4)$ & 23.7 (4) & $14.6(4)$ & $20.6 \quad(4)$ & $27.3(4)$ & $29.8 \quad(3)$ \\
\hline & 試料 2 & 12.2 (4) & 10.3 (4) & 10.4 (4) & 21.5 (4) & 17.6 (4) & 10.1 (3) \\
\hline & 試料 3 & $15.9(4)$ & $14.7(4)$ & $18.7(4)$ & $29.4 \quad(4)$ & 25.3 (4) & $10.5 \quad(3)$ \\
\hline \multirow{3}{*}{ コルチゾール } & 試料 1 & 5. 1 (5) & 3. 3 (5) & - & 14.3 (5) & 9. 4 (5) & $18.5 \quad(5)$ \\
\hline & 試料 2 & 4. 2 (5) & 5.1 (5) & $11.6 \quad(5)$ & $10.6(5)$ & $10.6 \quad(5)$ & $14.9(5)$ \\
\hline & 試料 3 & 4. $6(5)$ & 3. $5 \quad(5)$ & $11.5(5)$ & $16.8 \quad(5)$ & $12.8 \quad(5)$ & 15. 5（5) \\
\hline \multirow{3}{*}{ DHEA-S } & 試料 1 & - & - & - & $10.8(2)$ & - & 20.9 (2) \\
\hline & 試料 2 & 38.1 (2) & 42.1 (2) & 23.9 (2) & 23.7 (2) & 10.9 (2) & 37.4 (2) \\
\hline & 試料 3 & - & - & - & - & - & 14. 3（2） \\
\hline \multirow{3}{*}{ I g E } & 試料 1 & 4. $2(8)$ & $6.2(8)$ & 4. $2(8)$ & 8. $3(8)$ & $5.0(8)$ & $6.0(7)$ \\
\hline & 試料 2 & $5.6(8)$ & 9. 3 (8) & 8. 6 (8) & 5.9 (8) & $11.1(8)$ & 9. 9 (7) \\
\hline & 試料 3 & $5.4(8)$ & $10.0(8)$ & $13.5(8)$ & 8. $5(8)$ & $14.8(8)$ & 9. 7 (7) \\
\hline \multirow{3}{*}{$\begin{array}{l}\alpha \text {-フェト } \\
\text { プロテイン }\end{array}$} & 試料 1 & - & $21.5(8)$ & $10.6(7)$ & $12.4(6)$ & $12.2(6)$ & 10. $3(6)$ \\
\hline & 試料 2 & - & $26.6 \quad(8)$ & $18.1 （ 7)$ & $12.5(6)$ & 9. 7 (6) & 10.2（6) \\
\hline & 試料 3 & - & $31.1 \quad(8)$ & $23.4 \quad(7)$ & $13.8(6)$ & $10.3(6)$ & 7. $7(6)$ \\
\hline \multirow[t]{2}{*}{$\mathrm{CEA}$} & 試料 1 & $13.5(5)$ & $32.5 \quad(5)$ & $23.9(5)$ & $15.5(5)$ & $25.1 \quad(5)$ & 69.5 (4) \\
\hline & 試料 2 & 19. 7 (5) & $25.5 \quad(5)$ & $22.0(5)$ & $14.2(5)$ & $20.7 \quad(5)$ & 89.9 (4) \\
\hline \multirow[t]{2}{*}{ T P A } & 試料 1 & & 16.4 (2) & $48.6 \quad(3)$ & $43.9(3)$ & 50.4 (2) & 37.5 (2) \\
\hline & 試料 2 & - & - & - & - & _ & - \\
\hline \multirow[t]{2}{*}{ C A 125} & 試料 1 & $16.1 \quad(5)$ & 24.1 (4) & $11.9(4)$ & $10.2(4)$ & $13.6 \quad(3)$ & $14.6 \quad(3)$ \\
\hline & 試料 2 & $16.0(5)$ & 24.3 (4) & $11.6(4)$ & $11.7(4)$ & 10.3 (3) & 13.7 (3) \\
\hline \multirow[t]{2}{*}{ C A $19-9$} & 試料 1 & $27.2(5)$ & 35.7 (5) & $33.9 \quad(5)$ & $22.4 \quad(3)$ & $22.6 \quad(3)$ & $16.4 \quad(3)$ \\
\hline & 試料 2 & 36.2 (5) & 48. 5（5) & $40.9 \quad(5)$ & $34.0 \quad(3)$ & $30.0 \quad(3)$ & 18. 8 (3) \\
\hline
\end{tabular}


（続き）

\begin{tabular}{|c|c|c|c|c|c|c|c|}
\hline 項 & 目 & 第15回 & 第16回 & 第17回 & 第18回 & 第19回 & 第20回 \\
\hline \multirow[t]{2}{*}{ C A $15-3$} & 試料 1 & 7. 5 (4) & - & - & 8.0 (3) & 14.1 (3) & 6. 7 (3) \\
\hline & 試料 2 & 11.0 (4) & 7. 5 (4) & - & - & 7. $7(3$ & 4. 1 (3) \\
\hline \multirow[t]{2}{*}{ P A P } & 試料 1 & $14.8(5)$ & $23.5 \quad(5)$ & $20.4(5)$ & 29.4 (4) & $33.8 \quad(4$ & 28.3 (4) \\
\hline & 試料 2 & $13.2(4)$ & $19.6(5)$ & $15.7(4)$ & 26.4 (4) & $32.3(4)$ & 34.9 (3) \\
\hline \multirow[t]{2}{*}{$P A(P S A)$} & 試料 1 & 11.9 (3) & 8. 1 (4) & 21.8 (4) & 21.4 (4) & $11.5(4)$ & 5.8 (3) \\
\hline & 試料 2 & 16. 5 (3) & 12.8 (4) & $18.7(4)$ & 15.8 (4) & 5. 7 (4) & 10.6 (3) \\
\hline \multirow{2}{*}{$\begin{array}{c}\beta_{2} \text {-マイクロ } \\
\text { グロブリン }\end{array}$} & 試料 1 & 6. 2 (7) & - & $3.1 \quad 7)$ & 4. 7 (7) & 7. 9 (7) & 8. 1 (6) \\
\hline & 試料 2 & 4. 8 (7) & $6.8 \quad(7)$ & $5.2(7)$ & 7. 5 (7) & 8. $6(7)$ & 7. $2(6)$ \\
\hline \multirow[t]{2}{*}{ フェリチン } & 試料 1 & $29.4(11)$ & $13.8(8)$ & $14.1(7)$ & $14.8(7)$ & $14.3(7)$ & 3. $2(5)$ \\
\hline & 試料 2 & 29. $7(11)$ & $21.1 \quad(8)$ & $21.9(7)$ & $25.3 \quad(7)$ & $31.4 \quad(7)$ & 19. 2 (5) \\
\hline \multirow[t]{2}{*}{ NSE } & 試料 1 & - & - & - & - & - & 11.1 (5) \\
\hline & 試料 2 & - & - & - & - & - & 7. 5 (5) \\
\hline
\end{tabular}

注（）内は、測定系数。 
表10. 2 キット間変動係数（Between kit Variation $\mathrm{CV}(\%)$ ) の推移 （non-i s o t opic法による系）

\begin{tabular}{|c|c|c|c|c|c|c|c|}
\hline 項 & 目 & 第15回 & 第16回 & 第17回 & 第18回 & 第19回 & 第20回 \\
\hline $\mathrm{GH}$ & $\begin{array}{l}\text { 試料 } 1 \\
\text { 試料 } 2 \\
\text { 試料 } 3\end{array}$ & $\begin{array}{l}- \\
- \\
-\end{array}$ & $\begin{array}{l}- \\
- \\
-\end{array}$ & $\begin{array}{l}- \\
- \\
-\end{array}$ & $\begin{array}{l}- \\
- \\
-\end{array}$ & $\begin{array}{l}- \\
- \\
-\end{array}$ & $\begin{array}{ll}4.0 & (2) \\
1.1 & (2) \\
5.5 & (2)\end{array}$ \\
\hline F S H & $\begin{array}{l}\text { 試料 } 1 \\
\text { 試料 } 2 \\
\text { 試料 } 3\end{array}$ & $\begin{array}{ll}22.2 & (9) \\
22.5 & (9) \\
25.4 & (9)\end{array}$ & $\begin{array}{ll}13.2 & (9) \\
10.5 & (9) \\
14.3 & (9)\end{array}$ & $\begin{array}{l}16.7(12) \\
13.7(12) \\
20.6(12)\end{array}$ & $\begin{array}{l}15.1(14) \\
12.0(14) \\
15.8(14)\end{array}$ & $\begin{array}{l}10.6(14) \\
11.7(14) \\
18.7(14)\end{array}$ & $\begin{array}{l}13.4(14) \\
14.5(14) \\
19.3(14)\end{array}$ \\
\hline L H & $\begin{array}{l}\text { 試料 } 1 \\
\text { 試料 } 2 \\
\text { 試料 } 3\end{array}$ & $\begin{array}{ll}86.1 & (9) \\
40.4 & (9) \\
48.3 & (9)\end{array}$ & $\begin{array}{r}11.9(9) \\
5.4(9) \\
4.3(9)\end{array}$ & $\begin{array}{l}16.7(12) \\
12.8(12) \\
13.3(12)\end{array}$ & $\begin{array}{l}39.0(13) \\
16.5(13) \\
24.9(13)\end{array}$ & $\begin{array}{r}5.5(15) \\
21.3(15) \\
20.4(15)\end{array}$ & $\begin{array}{l}11.8(14) \\
12.5(14) \\
13.2(14)\end{array}$ \\
\hline プロラクチン & $\begin{array}{l}\text { 試料 } 1 \\
\text { 試料 } 2 \\
\text { 試料 } 3\end{array}$ & $\begin{array}{ll}27.5 & (9) \\
27.2 & (9) \\
23.6 & (9)\end{array}$ & $\begin{array}{ll}28.2 & (9) \\
29.9 & (9) \\
31.0 & (9)\end{array}$ & $\begin{array}{l}16.4(12) \\
20.6(12) \\
23.3(12)\end{array}$ & $\begin{array}{l}15.6(13) \\
18.7(13) \\
21.4(13)\end{array}$ & $\begin{array}{l}14.8(13) \\
22.1(13) \\
22.8(13)\end{array}$ & $\begin{array}{l}16.6(14) \\
19.1(14) \\
19.7(14)\end{array}$ \\
\hline T S H & $\begin{array}{l}\text { 試料 } 1 \\
\text { 試料 } 2 \\
\text { 試料 } 3\end{array}$ & $\begin{array}{l}21.7(13) \\
15.6(13) \\
15.9(13)\end{array}$ & $\begin{array}{l}13.7(14) \\
15.5(14) \\
16.9(14)\end{array}$ & $\begin{array}{l}13.7(12) \\
13.5(12) \\
11.7(12)\end{array}$ & $\begin{array}{l}23.1(12) \\
11.6(13) \\
12.3(13)\end{array}$ & $\begin{array}{r}20.5(15) \\
9.1(15) \\
10.5(15)\end{array}$ & $\begin{array}{l}21.4(15) \\
15.5(15) \\
11.2(15)\end{array}$ \\
\hline $\mathrm{T}_{3}$ & $\begin{array}{l}\text { 試料 } 1 \\
\text { 試料 } 2 \\
\text { 試料 } 3\end{array}$ & $\begin{array}{ll}4.4 & (9) \\
8.2 & (9) \\
9.5 & (9)\end{array}$ & $\begin{array}{ll}1.0 & (9) \\
3.9 & (9) \\
2.1 & (9)\end{array}$ & $\begin{array}{r}\text { 17. } 3(10) \\
\text { 7. } 8(10) \\
6.9(10)\end{array}$ & $\begin{array}{r}6.8(12) \\
8.7(12) \\
12.1(12)\end{array}$ & $\begin{array}{l}13.9(11) \\
16.7(11) \\
16.2(11)\end{array}$ & $\begin{array}{l}10.8(13) \\
12.7(13) \\
11.6(13)\end{array}$ \\
\hline Free $\mathrm{T}_{3}$ & $\begin{array}{l}\text { 試料 } 1 \\
\text { 試料 } 2 \\
\text { 試料 } 3\end{array}$ & $\begin{array}{rr}23.1 & (4) \\
6.5 & (4) \\
5.2 & (4)\end{array}$ & $\begin{array}{ll}25.3 & (8) \\
18.0 & (8) \\
21.1 & (8)\end{array}$ & $\begin{array}{ll}20.7 & (6) \\
13.5 \quad(6) \\
26.8 \quad(6)\end{array}$ & $\begin{array}{l}23.4(10) \\
23.4(10) \\
22.4 \quad(9)\end{array}$ & $\begin{array}{l}29.2(13) \\
27.1(13) \\
24.6(13)\end{array}$ & $\begin{array}{l}21.1(16) \\
30.5(16) \\
42.0(16)\end{array}$ \\
\hline $\mathrm{T}_{4}$ & $\begin{array}{l}\text { 試料 } 1 \\
\text { 試料 } 2 \\
\text { 試料 } 3\end{array}$ & $\begin{array}{l}\text { 7. } 9(13) \\
\text { 7. } 0(13) \\
\text { 8. } 2(13)\end{array}$ & $\begin{array}{r}10.4(12) \\
8.0(12) \\
10.1(12)\end{array}$ & $\begin{array}{l}9.1(12) \\
6.4(12) \\
9.5(12)\end{array}$ & $\begin{array}{r}11.8(13) \\
6.7(13) \\
8.1(13)\end{array}$ & $\begin{array}{r}12.5(14) \\
9.2(14) \\
10.8(14)\end{array}$ & $\begin{array}{r}\text { 15. } 4(13) \\
7.7(13) \\
9.2(13)\end{array}$ \\
\hline Free $\mathrm{T}_{4}$ & $\begin{array}{l}\text { 試料 } 1 \\
\text { 試料 } 2 \\
\text { 試料 } 3\end{array}$ & $\begin{array}{rr}8.9 & (7) \\
30.2 & (7) \\
25.0 & (5)\end{array}$ & $\begin{array}{r}6.2(10) \\
30.7(10) \\
25.7(10)\end{array}$ & $\begin{aligned} 8.1 & (9) \\
38.9 & (9) \\
17.4 & (9)\end{aligned}$ & $\begin{array}{l}16.0(10) \\
56.7(10) \\
23.2 \quad(8)\end{array}$ & $\begin{array}{l}23.2(14) \\
53.6(14) \\
31.7(14)\end{array}$ & $\begin{array}{l}25.3(15) \\
59.6(15) \\
34.6(15)\end{array}$ \\
\hline T B G & $\begin{array}{l}\text { 試料 } 1 \\
\text { 試料 } 2 \\
\text { 試料 } 3\end{array}$ & $\begin{array}{l}- \\
- \\
-\end{array}$ & $\begin{array}{l}- \\
- \\
-\end{array}$ & $\begin{array}{l}- \\
- \\
-\end{array}$ & $\begin{array}{l}- \\
- \\
-\end{array}$ & $\begin{array}{l}- \\
- \\
-\end{array}$ & $\begin{array}{ll}4.9 & (2) \\
5.8 & (2) \\
2.3 & (2)\end{array}$ \\
\hline インスリン & $\begin{array}{l}\text { 試料 } 1 \\
\text { 試料 } 2 \\
\text { 試料 } 3\end{array}$ & $\begin{array}{l}17.4(10) \\
19.8(10) \\
16.7(10)\end{array}$ & $\begin{array}{ll}14.5 & (9) \\
22.1 & (9) \\
17.9 & (9)\end{array}$ & $\begin{array}{ll}15.7 & (9) \\
16.1 & (9) \\
20.4 & (9)\end{array}$ & $\begin{array}{ll}37.4 & (9) \\
35.8 & (9) \\
41.1 & (9)\end{array}$ & $\begin{array}{l}24.2(10) \\
24.5(10) \\
29.0(10)\end{array}$ & $\begin{array}{l}15.1(10) \\
15.5(10) \\
18.5(10)\end{array}$ \\
\hline C-ペプチド & $\begin{array}{l}\text { 試料 } 1 \\
\text { 試料 } 2 \\
\text { 試料 } 3\end{array}$ & $\begin{array}{l}- \\
- \\
-\end{array}$ & $\begin{array}{l}- \\
- \\
-\end{array}$ & $\begin{array}{ll}4.6 & (2) \\
1.3 & (2) \\
1.5 & (2)\end{array}$ & $\begin{array}{l}- \\
- \\
-\end{array}$ & $\begin{array}{r}27.0(2) \\
8.3(2) \\
-\end{array}$ & $\begin{array}{ll}6.4 & (2) \\
5.0 & (2) \\
5.6 & (2)\end{array}$ \\
\hline テストステロン & $\begin{array}{l}\text { 試料 } 1 \\
\text { 試料 } 2 \\
\text { 試料 } 3\end{array}$ & $\begin{array}{l}- \\
- \\
-\end{array}$ & $\begin{array}{l}- \\
- \\
-\end{array}$ & $\begin{array}{l}- \\
- \\
-\end{array}$ & $\begin{array}{rr}39.0 & (3) \\
5.7 & (3) \\
9.7 & (3)\end{array}$ & $\begin{array}{ll}45.8 & (3) \\
10.7 & (3) \\
15.0 & (3)\end{array}$ & $\begin{array}{ll}41.3 & (5) \\
14.5 & (5) \\
16.8 & (5)\end{array}$ \\
\hline
\end{tabular}


（続き）

\begin{tabular}{|c|c|c|c|c|c|c|c|}
\hline 項 & 目 & 第15回 & 第16回 & 第17回 & 第18回 & 第19回 & 第20回 \\
\hline & 試料 1 & 64.7 (4) & $77.6(5)$ & $96.0(6)$ & $67.2(8)$ & 46. $6(10)$ & 30. $2(10)$ \\
\hline エストラジオー) & レ試料 2 & 82.8 (4) & 88.5 (5) & $53.2(6)$ & 46.7 (8) & 44. $9(10)$ & $35.5(10)$ \\
\hline & 試料 3 & $68.8(4)$ & 76.9 (5) & 57.1 (6) & $61.8(8)$ & $66.5(10)$ & $60.4(10)$ \\
\hline & 試料 1 & - & 29.2 (3) & $23.3(5)$ & $28.8(7)$ & $23.8(8)$ & 30.5 (9) \\
\hline プロゲステロン & 試料 2 & - & 14.4 (3) & $18.8(5)$ & $13.6(7)$ & $15.4(8)$ & 17. 6 (9) \\
\hline & 試料 3 & - & $15.3(3)$ & $24.2(5)$ & $30.6(7)$ & $27.9(8)$ & $23.8(9)$ \\
\hline & 試料 1 & - & - & II 4.8 (2) & III $6.6 \quad$ (6) & II 8.1 (6) & II 9.5 (5) \\
\hline$\beta \mathrm{HC} \mathrm{G}$ & 試料 2 & - & - & II 7.9 (2) & II $5.5 \quad(6)$ & - & II 2.0 (5) \\
\hline & 試料 3 & - & - & II 4.2 (2) & II $4.1 \quad(6)$ & II & II 7.6 (5) \\
\hline & 試料 1 & - & 0.7 (4) & $12.8(5)$ & - & - & 18. $9(10)$ \\
\hline コルチゾール & 試料 2 & $5.5(3)$ & 7. 4 (4) & 12.4 (5) & $12.5(7)$ & 9.1 (8) & 11. $3(10)$ \\
\hline & 試料 3 & $10.1 \quad(3)$ & $11.3(4)$ & $11.1(5)$ & $12.3(7)$ & $8.8(8)$ & 10. $5(10)$ \\
\hline & 試料 1 & 12. $0(15)$ & $11.5(14)$ & 14. $5(13)$ & 15. $4(14)$ & 9. $4(15)$ & 8. $5(17)$ \\
\hline$I \mathrm{~g} \mathrm{E}$ & 試料 2 & $11.8(15)$ & 19. $0(14)$ & 14. $3(13)$ & 13. $9(14)$ & 10.7(15) & 8. 6(17) \\
\hline & 試料 3 & 14. $7(15)$ & $20.0(14)$ & 14. 1(13) & 15. $9(14)$ & 11. $9(15)$ & 10. $0(17)$ \\
\hline & 試料 1 & $26.6(9)$ & 8. $6 \quad(7)$ & $17.6(8)$ & 10. $8(11)$ & 6. 3 (9) & 14. $9(11)$ \\
\hline ジゴキシン & 試料 2 & $10.1(9)$ & $6.9(7)$ & $10.9(8)$ & 5. $2(11)$ & $5.4(9)$ & 7. $5(11)$ \\
\hline & 試料 3 & 8. $8(9)$ & $8.4 \quad(7)$ & $7.5 \quad(8)$ & 3. $2(11)$ & 3. $6 \quad(9)$ & 8. $3(11)$ \\
\hline$\alpha$-フェト & 試料 1 & - & 9. $1(17)$ & $11.1(15)$ & 8. $8(17)$ & 6. 1(16) & 7. $2(16)$ \\
\hline プロテイン & 試料 2 & - & 7. $5(17)$ & 11. $6(15)$ & 8. $7(17)$ & 8. 6(16) & 5. $4(16)$ \\
\hline & 試料 3 & - & 8. $9(17)$ & $11.8(15)$ & 12. $0(17)$ & $10.9(16)$ & 5. $4(16)$ \\
\hline C E A & 試料 1 & 20. $2(16)$ & 20. $9(16)$ & 28. $3(16)$ & 23. $2(16)$ & 26. $9(15)$ & 44. $4(16)$ \\
\hline & 試料 2 & 17. $6(16)$ & 18. 8(16) & $34.6(16)$ & 27. 4(16) & 26. $6(15)$ & $51.4(16)$ \\
\hline C A 125 & 試料 1 & 28.1 (5) & $15.8 \quad(5)$ & $16.9(7)$ & $17.5(8)$ & $20.4(10)$ & $25.5(11)$ \\
\hline & 試料 2 & $23.5 \quad(5)$ & $11.6(5)$ & $11.9(7)$ & $15.9(8)$ & 19. $2(10)$ & 28. $9(11)$ \\
\hline C A $19-9$ & 試料 1 & 43. 1(10) & $28.4(11)$ & 28. 9 (14) & 18. $9(14)$ & 13. 1(12) & 27. 7(14) \\
\hline & 試料 2 & $35.4(10)$ & $30.6(11)$ & $29.7(14)$ & $32.8(14)$ & $32.5(12)$ & $15.5(14)$ \\
\hline C A $15-3$ & 試料 1 & 34.7 (2) & $9.9(2)$ & $18.8(5)$ & 18. $4(7)$ & $19.8(7)$ & $13.1(7)$ \\
\hline & 試料 2 & $19.0 \quad(2)$ & 4. 3（2） & $14.7(5)$ & 8. $9 \quad(7)$ & $15.0 \quad(7)$ & $8.1(7)$ \\
\hline$P A P$ & 試料 1 & 26.2 (3) & 19.1 (4) & 17. $3(6)$ & 13.5（3) & $18.9 \quad(6)$ & $29.0(6)$ \\
\hline & 試料 2 & 8.1 (2) & $3.9 \quad(4)$ & $19.1(6)$ & - & $17.5 \quad(6)$ & 26. $7(6)$ \\
\hline $\mathrm{PA}(\mathrm{PSA})$ & 試料 1 & $58.5 \quad(7)$ & $55.9(9)$ & $53.8(10)$ & $51.4(12)$ & $34.7(16)$ & $45.5(20)$ \\
\hline & 試料 2 & $60.7(7)$ & 54. $5 \quad(9)$ & 49. $7(10)$ & $52.8(11)$ & $41.9(16)$ & 44. $2(20)$ \\
\hline$\beta_{2}$-マイクロ & 試料 1 & 8. 5 (14) & 10. $6(14)$ & $15.9(14)$ & 5. $5(18)$ & $11.1(16)$ & $11.1(16)$ \\
\hline グロブリン & 試料 2 & 7. $4(14)$ & 11. $5(14)$ & $12.1(14)$ & 5. $0(18)$ & $10.4(16)$ & 11. $3(16)$ \\
\hline フェリチン & 試料 1 & $31.7(15)$ & 30. $7(16)$ & 28. $8(16)$ & 16. $4(16)$ & 17. $6(17)$ & 15. $0(19)$ \\
\hline & 試料 2 & $6.4(15)$ & $11.7(16)$ & $12.4(16)$ & 17. $5(16)$ & $11.5(17)$ & 12. $2(19)$ \\
\hline N S E & 試料 1 & - & - & - & - & - & $10.7(2)$ \\
\hline & 試料 2 & - & - & - & - & - & $14.5(2)$ \\
\hline
\end{tabular}

注（）内は、測定系数。 
表10. 3 キット間変動係数（Between kit Variation CV (\%)) の推移 （i sotopic法およびnon-i sotopic法による系）

\begin{tabular}{|c|c|c|c|c|c|c|c|}
\hline 項 & 目 & 第15回 & 第16回 & 第17回 & 第18回 & 第19回 & 第20回 \\
\hline \multirow{3}{*}{ G H } & 試料 1 & 13.2 (6) & $13.7(6)$ & $25.0 \quad(6)$ & $16.3(6)$ & 20.3 (4) & $18.4(4)$ \\
\hline & 試料 2 & $14.7(6)$ & $14.6(6)$ & 28.4 (6) & $17.9(6)$ & 21.3 (4) & 20.0 \\
\hline & 試料 3 & $13.9(6)$ & $12.5(6)$ & $19.6 \quad(6)$ & $19.5(6)$ & $22.0 \quad(4)$ & $24.2(4)$ \\
\hline \multirow{3}{*}{ ソマトメジンC } & 試料 1 & - & 36.3 (2) & $49.0 \quad(2)$ & $45.1 \quad(3)$ & 34.2 (3) & 20.8 (3) \\
\hline & 試料 2 & - & 40. 4 (2) & $57.0 \quad(2)$ & $57.8 \quad(3)$ & 53.9 (3) & 24.3 \\
\hline & 試料 3 & - & 52.2 (2) & 69.2 (2) & 72.2 (3) & 79.3 (3) & $39.4 \quad(3)$ \\
\hline \multirow{3}{*}{ F S H } & 試料 1 & 17. $7(16)$ & 15. $9(15)$ & 15. $8(16)$ & $15.1(17)$ & 15. $6(17)$ & 16. 7(17) \\
\hline & 試料 2 & 17. 1(16) & 13. $5(15)$ & 13. 4(16) & $12.8(17)$ & 14. $5(17)$ & 15. 5(17) \\
\hline & 試料 3 & $20.4(16)$ & 16. $3(15)$ & 19. 7(16) & 16. $3(17)$ & 18. $4(17)$ & $20.1(17)$ \\
\hline \multirow{3}{*}{ L H } & 試料 1 & 44. 8(16) & $22.9(15)$ & $20.3(16)$ & $31.8(17)$ & $20.8(18)$ & $21.1(17)$ \\
\hline & 試料 2 & $24.1(16)$ & 15. $2(15)$ & 14. $9(16)$ & 17. $2(17)$ & 19. $2(18)$ & 18. $2(17)$ \\
\hline & 試料 3 & $30.6(16)$ & 17. $3(15)$ & 15. 6(16) & $22.3(17)$ & 20. $9(18)$ & $31.5(17)$ \\
\hline \multirow{3}{*}{ プロラクチン } & 試料 1 & $45.5(17)$ & 41. 5(16) & $42.1(18)$ & 38. $0(19)$ & $34.1(18)$ & $33.9(18)$ \\
\hline & 試料 2 & $44.4(17)$ & 41. 8(16) & $39.1(18)$ & $32.0(19)$ & $29.8(18)$ & $34.9(18)$ \\
\hline & 試料 3 & 43. 8(i7) & 42. $2(16)$ & 39. 7(18) & 29. $9(19)$ & 29. 1(18) & 34. 2(18) \\
\hline \multirow{3}{*}{ T S H } & 試料 1 & $15.9(22)$ & 12. $4(23)$ & 11. $6(19)$ & 19. 4(18) & $15.9(20)$ & $17.2(21)$ \\
\hline & 試料 2 & 10. $4(22)$ & 12. $0(23)$ & $11.8(19)$ & 11. 1(19) & 9. $6(20)$ & 13. $4(21)$ \\
\hline & 試料 3 & 10. $5(22)$ & 12. $4(23)$ & $11.0(19)$ & 11. $2(19)$ & 9. $7(20)$ & $11.5(21)$ \\
\hline \multirow{3}{*}{$T_{3}$} & 試料 1 & 9. $5(20)$ & 6. $9(19)$ & 12. $5(19)$ & 7. $4(21)$ & 11. $4(18)$ & 9. $4(20)$ \\
\hline & 試料 2 & $12.1(20)$ & 12. $8(19)$ & 13. $0(19)$ & 13. $4(21)$ & 17. $4(18)$ & 14. $5(20)$ \\
\hline & 試料 3 & 14. $2(20)$ & 13. $8(19)$ & 13. $9(19)$ & 13. $8(21)$ & 16. $9(18)$ & 14. $2(20)$ \\
\hline \multirow{3}{*}{ Free $\mathrm{T}_{3}$} & 試料 1 & $24.0(10)$ & 27. 1(13) & $23.0(11)$ & 22. 8(14) & 28. 7(16) & $24.0(20)$ \\
\hline & 試料 2 & 25. $2(10)$ & 25. $2(13)$ & $20.1(11)$ & 24. 8(14) & 26. 3(16) & 27. $9(20)$ \\
\hline & 試料 3 & $34.4(10)$ & $29.4(13)$ & $26.1(11)$ & 23. $4(13)$ & $21.6(16)$ & $34.5(20)$ \\
\hline \multirow{3}{*}{$\mathrm{T}}$. & 試料 1 & 6.2(23) & 10.0(21) & 7. $7(22)$ & 8. 4(23) & 8. $7(22)$ & $11.5(20)$ \\
\hline & 試料 2 & 4. $8(23)$ & 5. $6(21)$ & 4. $8(22)$ & 6. $5(23)$ & 7. $4(22)$ & 6. $9(20)$ \\
\hline & 試料 3 & 6. $1(23)$ & 7. 7(21) & 7. $2(22)$ & 7. $5(23)$ & 8. $5(22)$ & $8.1(20)$ \\
\hline \multirow{3}{*}{ Free $T_{4}$} & 試料 1 & 27. $5(16)$ & $24.1(17)$ & $13.0(17)$ & 16. 4(17) & 22. $9(20)$ & 24. $3(21)$ \\
\hline & 試料 2 & 27. $8(16)$ & 26. $9(18)$ & 36. $3(17)$ & 46. $2(17)$ & 44. $9(20)$ & $50.1(21)$ \\
\hline & 試料 3 & $36.1(14)$ & 37. $7(18)$ & $40.0(17)$ & $102 \quad(14)$ & 32. 2(19) & $32.9(21)$ \\
\hline \multirow{3}{*}{ T B G } & 試料 1 & $8.7(6)$ & $5.5(6)$ & $8.7(7)$ & 6.1 (6) & 10.5 & $10.4 \quad(4)$ \\
\hline & 試料 2 & 7.5 (6) & $8.3(6)$ & 9.0 (7) & $8.8(6)$ & 11.1 & 16.5 \\
\hline & 試料 3 & $8.9(6)$ & $11.0(6)$ & 12.0 & 8. $2(6)$ & 14.8 & 17.3 \\
\hline \multirow{3}{*}{ カルシトニン } & 試料 1 & 49.2 (4) & $51.5(4)$ & $42.8 \quad(4)$ & $46.6 \quad(4)$ & 40.9 (4) & $40.8 \quad(4)$ \\
\hline & 試料 2 & - & 8.6 (4) & 5.7 (4) & 16.6 (4) & 16.5 (4) & $19.8 \quad(4)$ \\
\hline & 試料 3 & - & 6.1 (4) & $14.6 \quad(4)$ & 25.2 (4) & 23.9 (4) & $21.9(4)$ \\
\hline
\end{tabular}


（続き）

\begin{tabular}{|c|c|c|c|c|c|c|c|}
\hline 項 & 目 & 第15回 & 第16回 & 第17回 & 第18回 & 第19回 & 第20回 \\
\hline \multirow{3}{*}{ インスリン } & 1 & 16. 3(16) & $2(15)$ & 15. 6(15) & 23. $8(15)$ & 18. $9(16)$ & 15. 6(16) \\
\hline & 斗 2 & $7(16)$ & $1.5(15)$ & 13. $1(15)$ & $20.5(15)$ & 16. $2(16)$ & 13. $2(16)$ \\
\hline & 試料 3 & 1. $6(16)$ & 10. $9(15)$ & 15. $0(15)$ & $22.8(15)$ & 18. $5(16)$ & $16.1(16)$ \\
\hline \multirow{3}{*}{ Cーペプチド } & +1 & $4(2)$ & 1. $5(2)$ & 4. $9(4)$ & 25.0 (3) & $18.6 \quad(5)$ & 19.4 (4) \\
\hline & 斗 2 & 18.2 (2) & 18.1 (2) & 24.8 (4) & 28.9 (3) & 17. $3(5)$ & $19.3(4)$ \\
\hline & +3 & 41.5 (2) & 39.1 (2) & 38.9 (4) & 37.1 (3) & 22.4 (5) & 24.2 (4) \\
\hline \multirow{3}{*}{ テストステロン } & 斗 1 & 30.8 (3) & $37.0 \quad(3)$ & 56.0 (4) & 29.1 (6) & $27.1 \quad(6)$ & 32.1 (8) \\
\hline & 試料 2 & $27.7(3)$ & 20.5 (3) & 38.9 (4) & $32.1 \quad(6)$ & 29. 9 (6) & 22.1 (8) \\
\hline & 試料 3 & 47.3 (3) & 37.4 (3) & 56.9 (4) & $37.7(6)$ & 27.8 (6) & 26.8 (8) \\
\hline \multirow{3}{*}{ エストラジオー) } & 試料 1 & $71.3(8)$ & $94.7(9)$ & $114 \quad(10)$ & 77. 4(11) & $63.4(14)$ & $54.0(14)$ \\
\hline & ル試料 2 & $52.6 \quad(8)$ & $75.6 \quad(9)$ & $41.1(10)$ & $35.0(11)$ & $35.5(14)$ & 29. 6(14) \\
\hline & 試料 3 & 32.7 (8) & $52.2(9)$ & 43. $6(10)$ & 46. $6(11)$ & 49. $5(14)$ & 48. $2(14)$ \\
\hline \multirow{3}{*}{ プロゲステロン } & 1 & $31.0(4)$ & $28.0 \quad(6)$ & $31.4(8)$ & (10) & $19.5(11)$ & 27. $6(12)$ \\
\hline & 試料 2 & 25.5 (4) & $16.7(6)$ & 17. $7(8)$ & 17. $2(10)$ & 19. $4(11)$ & 17. $6(12)$ \\
\hline & 3 & 36.9 (4) & $26.6(6)$ & 24.5 (8) & 26. $2(10)$ & 28. $4(11)$ & 23. $7(12)$ \\
\hline \multirow{5}{*}{$\beta \mathrm{HC} \mathrm{G}$} & 头 1 & . & - & I - & I $-{ }^{\prime}{ }_{6}$ & $\begin{array}{lll}\mathrm{I} & - & \\
\mathrm{II} & 8 & (6)\end{array}$ & $\begin{array}{lll}\text { I } & 8.2 & \text { (2) } \\
\text { II } & 9 & 5\end{array}$ \\
\hline & 試料 2 & & & $\mathrm{I}-$ & I - & $\mathrm{I}-$ & I - \\
\hline & & - & - & II 7.9 (2) & II 5.5 (6) & II 0.0 (6) & II 2.0 (5) \\
\hline & 3 & & & I $\quad-$ & I & - & I 3.8 (2) \\
\hline & & - & - & II 4.2 (2) & II $4.1 \quad(6)$ & II 0.0 (6) & II 7.6 (5) \\
\hline \multirow{3}{*}{ アルドステロン } & 斗 1 & $25.6(4)$ & 23.7 (4) & 14. 6 (4) & 20.6 (3) & 27.3 (4) & 29.8 (3) \\
\hline & +2 & $12.2(4)$ & 10.3 (4) & 10.4 (4) & 21.5 (4) & $17.6(4)$ & 10.1 (3) \\
\hline & & $15.9(4)$ & $14.7(4)$ & 18. $7(4)$ & 29. 4（4） & 25.3 (4) & 10. 5 (3) \\
\hline \multirow{3}{*}{ コルチゾール } & 斗 1 & $3.8(8)$ & $5.8(9)$ & 5. $3(10)$ & 13. $9(12)$ & 11. $9(13)$ & 18. $3(15)$ \\
\hline & 試料 2 & 7. 4 (8) & 7. 2 (9) & 12. $4(10)$ & $11.4(12)$ & 9. $6(13)$ & 12. $8(15)$ \\
\hline & & 8. 0 (8) & 6. $6 \quad(9)$ & 10. $9(10)$ & 14. $6(12)$ & $10.9(13)$ & 12. $8(15)$ \\
\hline \multirow{3}{*}{ DHEA-S } & & - & - & - & $30.5(3)$ & $27.6(4)$ & $20.9(2)$ \\
\hline & 2 & - & 42.1 (2) & 23.9 (2) & $15.8(4)$ & $17.6(4)$ & 37.4 (2) \\
\hline & & - & - & - & - & 25.3 (4) & 14. 3（2） \\
\hline \multirow{3}{*}{ I g E } & & 0 & 2) & 9. 9 & 12. $3(22)$ & 7. $6(23)$ & 8. $4(24)$ \\
\hline & & 9. $3(23)$ & 13. $2(22)$ & $11.1(21)$ & 10. $9(22)$ & $10.5(23)$ & 8. $7(24)$ \\
\hline & 3 & 10. $4(23)$ & 14. $5(22)$ & 13. $3(21)$ & 12. $9(22)$ & 12. $7(23)$ & 9. $6(24)$ \\
\hline \multirow{3}{*}{ ジゴキシン } & & $26.3(11)$ & $13.8(9)$ & 17. $9(10)$ & $10.5(12)$ & 5. $8(10)$ & 14. 8(12) \\
\hline & & 9. $5(11)$ & 8. 5 (9) & 11. 5(10) & 4. $9(12)$ & 5. $1(10)$ & 7. $3(12)$ \\
\hline & & 7. 2(11) & 8. $5(9)$ & 9. $3(10)$ & 3. $1(12)$ & 3. $6(10)$ & 8. 1(12) \\
\hline \multirow{3}{*}{$\begin{array}{l}\alpha-\text { フェト } \\
\text { プロテイン }\end{array}$} & 試料 1 & - & 15. $3(25)$ & 10. $4(22)$ & $10.4(23)$ & 8. $2(22)$ & 9. $6(22)$ \\
\hline & & - & $18.1(25)$ & 15. $6(22)$ & 10. $4(23)$ & 9. $3(22)$ & 9. $1(22)$ \\
\hline & 試料 3 & - & $21.3(25)$ & 18. $7(22)$ & 13. $3(23)$ & $11.5(22)$ & 9. $0(22)$ \\
\hline
\end{tabular}


（続き）

\begin{tabular}{|c|c|c|c|c|c|c|c|}
\hline 項 & 目 & 第15回 & 第16回 & 第17回 & 第18回 & 第19回 & 第20回 \\
\hline \multirow[t]{2}{*}{ C E A } & 試料 1 & $50.0(21)$ & $45.6(21)$ & $57.3(21)$ & $51.0(21)$ & $51.5(20)$ & $73.9(20)$ \\
\hline & 試料 2 & 46. $3(21)$ & - & $65.5(21)$ & $52.0(21)$ & 48. $8(20)$ & 85. $2(20)$ \\
\hline \multirow[t]{2}{*}{ T P A } & 試料 1 & 4. 0 (1) & 16.4 (2) & 48. $6 \quad(3)$ & 44. 9 (3) & $51.4 \quad(3)$ & 38.0 (3) \\
\hline & 試料 2 & - & - & - & - & - & - \\
\hline \multirow[t]{2}{*}{ C A 125} & 試料 1 & $18.1(10)$ & $19.6(9)$ & 12. $7(11)$ & 12. $4(12)$ & $15.8(13)$ & $19.4(14)$ \\
\hline & 試料 2 & 16. $3(10)$ & $18.8(9)$ & $11.9(11)$ & 12. $4(12)$ & $14.1(13)$ & 23. $2(14)$ \\
\hline \multirow[t]{2}{*}{ C A $19-9$} & 試料 1 & 43.1 (15) & 46. $1(16)$ & 29. $5(19)$ & 17. $6(17)$ & 17. $7(15)$ & $22.1(17)$ \\
\hline & 試料 2 & $39.4(15)$ & 44. $3(16)$ & $33.8(19)$ & $32.4(17)$ & 33. $7(15)$ & 14. $0(17)$ \\
\hline \multirow[t]{2}{*}{ C A $15-3$} & 試料 1 & $13.3(6)$ & - & 8.0 (9) & 13. $2(10)$ & 15. $3(10)$ & 9. $8(10)$ \\
\hline & 試料 2 & $12.2(6)$ & $6.4(6)$ & 7. 8 (9) & $8.0(10)$ & $11.5(10)$ & 10. $6(10)$ \\
\hline \multirow[t]{2}{*}{ P A P } & 試料 1 & $15.2(8)$ & $21.6(9)$ & 19. 1(11) & $22.6(7)$ & 26. $6(10)$ & 28. $2(10)$ \\
\hline & 試料 2 & $11.4(6)$ & $15.9(9)$ & $16.1(10)$ & $22.8(7)$ & 23. $9(10)$ & 30.4 (9) \\
\hline \multirow[t]{2}{*}{$P A(P S A)$} & 試料 1 & $53.9(10)$ & $58.4(13)$ & $59.9(14)$ & 54. 7(16) & 37. 1(20) & 44. 9 (23) \\
\hline & 試料 2 & $52.4(10)$ & $56.9(13)$ & 55. 2(14) & $56.9(16)$ & 45. $0(20)$ & 43. 4 (23) \\
\hline \multirow{2}{*}{$\begin{array}{c}\beta_{2}-\text {-マイクロ } \\
\text { グロブリン }\end{array}$} & 試料 1 & 7. $6(21)$ & - & 10. $4(21)$ & 4. $8(25)$ & 9. $3(23)$ & 9. $9(22)$ \\
\hline & 試料 2 & 7. $4(21)$ & 8. $3(21)$ & 9. $2(21)$ & 6. $6(25)$ & 9. $2(23)$ & 9. $5(22)$ \\
\hline \multirow[t]{2}{*}{ フェリチン } & 試料 1 & $32.7(26)$ & $28.4(24)$ & $25.6(23)$ & 16. $7(23)$ & 17. $0(24)$ & $15.4(24)$ \\
\hline & 試料 2 & 22. 6(26) & 18. $2(24)$ & 18. $6(23)$ & $20.1(23)$ & 19. $6(24)$ & 17. $7(24)$ \\
\hline \multirow[t]{2}{*}{ NSE } & 試料 1 & - & - & - & - & - & $16.5 \quad(7)$ \\
\hline & 試料 2 & - & - & - & - & - & 8. 1 (7) \\
\hline
\end{tabular}

注（）内は、測定系数。 
表11 キットごとの変動係数（CV（\%)) の推移

\begin{tabular}{|c|c|c|c|c|c|c|}
\hline キット名 & 第15回 & 第16回 & 第17回 & 第18回 & 第19回 & 第20回 \\
\hline $\begin{aligned} \text { Hキット「第一」試料1 } & \text { 試料 } 2 \\
& \text { 試料 } 3\end{aligned}$ & $\begin{array}{ll}6.5 & (28) \\
6.2 & (28) \\
6.5 & (28)\end{array}$ & $\begin{array}{ll}5.1 & (25) \\
5.3 & (26) \\
6.1 & (27)\end{array}$ & $\begin{array}{ll}9.5 & (24) \\
9.1 & (25) \\
7.1 & (24)\end{array}$ & $\begin{array}{ll}7.1 & (25) \\
7.6 & (26) \\
6.2 & (26)\end{array}$ & $\begin{array}{ll}6.5 & (26) \\
7.0 & (26) \\
6.1 & (26)\end{array}$ & $\begin{array}{ll}7.7 & (26) \\
5.8 & (26) \\
4.3 & (25)\end{array}$ \\
\hline $\begin{array}{rll}\mathrm{Ab} \text { b゙ーズH GH } & \text { 試料1 } \\
\text { '栄研' } & \text { 試料2 } \\
& \text { 試料 } 3\end{array}$ & $\begin{array}{ll}7.8 & (21) \\
5.1 & (21) \\
5.1 & (21)\end{array}$ & $\begin{array}{ll}8.5 & (17) \\
4.3 & (16) \\
3.7 & (16)\end{array}$ & $\begin{array}{ll}7.9 & (17) \\
3.3 & (16) \\
3.3 & (17)\end{array}$ & $\begin{array}{ll}4.6 & (19) \\
3.9 & (20) \\
3.2 & (19)\end{array}$ & $\begin{array}{ll}5.8 & (19) \\
3.7 & (19) \\
4.2 & (19)\end{array}$ & $\begin{array}{ll}8.0 & (14) \\
8.0 & (14) \\
6.7 & (14)\end{array}$ \\
\hline $\begin{array}{cc}\text { ソマトメジンC・ } & \text { 試料1 } \\
\text { II「カイロン」 } & \text { 試料 } 2 \\
& \text { 試料 } 3\end{array}$ & $\begin{array}{l}- \\
- \\
-\end{array}$ & \begin{tabular}{rr|}
12.8 & $(11)$ \\
9.7 & $(11)$ \\
13.4 & $(11)$
\end{tabular} & $\begin{array}{rr}10.3 & (12) \\
8.3 & (12) \\
8.8 & (12)\end{array}$ & $\begin{array}{ll}4.7 & (12) \\
7.3 & (13) \\
5.1 & (13)\end{array}$ & $\begin{array}{ll}5.0 & (12) \\
5.2 & (12) \\
8.0 & (12)\end{array}$ & $\begin{array}{ll}4.1 & (11) \\
6.0 & (12) \\
4.3 & (11)\end{array}$ \\
\hline $\begin{array}{rr}\text { スパック-S } & \text { 試料1 } \\
\mathrm{F} \mathrm{SHキット} & \text { 試料2 } \\
& \text { 試料 } 3\end{array}$ & $\begin{array}{ll}6.9 & (44) \\
6.6 & (43) \\
3.9 & (41)\end{array}$ & $\begin{array}{ll}4.7 & (39) \\
5.0 & (39) \\
4.2 & (39)\end{array}$ & $\begin{array}{ll}4.4 & (35) \\
5.3 & (36) \\
3.3 & (35)\end{array}$ & $\begin{array}{ll}4.9 & (32) \\
4.1 & (31) \\
4.1 & (32)\end{array}$ & $\begin{array}{ll}3.8 & (30) \\
3.9 & (30) \\
4.2 & (30)\end{array}$ & $\begin{array}{ll}4.3 & (27) \\
3.6 & (28) \\
4.9 & (28)\end{array}$ \\
\hline $\begin{array}{rr}\text { アキシム F S H } & \text { 試料1 } \\
\text { ・ダイナパック } & \begin{array}{l}\text { 試料 } 2 \\
\text { 試料 } 3\end{array}\end{array}$ & $\begin{array}{l}- \\
- \\
-\end{array}$ & $\begin{array}{rr}7.8 & (5) \\
7.7 & (5) \\
11.5 & (5)\end{array}$ & $\begin{array}{ll}6.9 & (9) \\
3.8 & (8) \\
5.6 & (9)\end{array}$ & $\begin{array}{ll}5.1 & (12) \\
5.1 & (12) \\
4.5 & (12)\end{array}$ & $\begin{array}{ll}7.7 & (16) \\
6.4 & (15) \\
7.4 & (15)\end{array}$ & $\begin{array}{ll}5.8 & (13) \\
6.2 & (13) \\
4.7 & (13)\end{array}$ \\
\hline $\begin{array}{rr}\text { ケミルミA C S - } & \text { 試料1 } \\
\text { F S H } & \text { 試料 } 2 \\
& \text { 試料 } 3\end{array}$ & $\begin{array}{ll}6.7 & (8) \\
2.9 & (7) \\
4.8 & (8)\end{array}$ & $\begin{array}{ll}3.7 & (10) \\
2.5 & (10) \\
3.9 & (10)\end{array}$ & $\begin{array}{ll}4.1 & (11) \\
2.8 & (10) \\
3.4 & (10)\end{array}$ & $\begin{array}{ll}6.9 & (16) \\
5.3 & (16) \\
5.6 & (16)\end{array}$ & $\begin{array}{ll}3.1 & (14) \\
4.5 & (15) \\
3.4 & (14)\end{array}$ & $\begin{array}{ll}3.3 & (15) \\
3.6 & (13) \\
3.8 & (14)\end{array}$ \\
\hline $\begin{array}{r}\text { スパック-S L H 試料1 } \\
\text { キット 試料2 } \\
\text { 試料3 }\end{array}$ & $\begin{array}{ll}5.6 & (43) \\
4.6 & (44) \\
5.0 & (43)\end{array}$ & $\begin{array}{ll}4.3 & (39) \\
4.5 & (38) \\
5.2 & (38)\end{array}$ & $\begin{array}{ll}4.5 & (36) \\
5.2 & (35) \\
4.7 & (35)\end{array}$ & $\begin{array}{ll}6.9 & (32) \\
4.9 & (32) \\
5.6 & (30)\end{array}$ & $\begin{array}{ll}8.2 & (30) \\
5.2 & (30) \\
3.1 & (29)\end{array}$ & $\begin{array}{ll}5.7 & (27) \\
4.5 & (28) \\
6.5 & (28)\end{array}$ \\
\hline $\begin{array}{lr}\text { アキシム } \mathrm{L} \mathrm{H} & \text { 試料1 } \\
\text { ・ダイナパック } & \text { 試料 } 2 \\
& \text { 試料 } 3\end{array}$ & $\begin{array}{l}- \\
- \\
-\end{array}$ & $\begin{array}{ll}7.7 & (5) \\
5.1 & (5) \\
4.5 & (5)\end{array}$ & $\begin{array}{ll}10.8 & (8) \\
9.2 & (8) \\
10.1 & (8)\end{array}$ & $\begin{aligned} 10.2 & (13) \\
6.7 & (12) \\
8.7 & (12)\end{aligned}$ & $\begin{array}{rr}9.2 & (16) \\
9.0 & (16) \\
10.5 & (16)\end{array}$ & $\begin{array}{ll}5.1 & (13) \\
4.7 & (13) \\
5.0 & (13)\end{array}$ \\
\hline $\begin{array}{rr}\text { スパック-S } & \text { 試料 } 1 \\
\text { プロラクチン } & \text { 試料 } 2 \\
\text { キット } & \text { 試料 } 3\end{array}$ & $\begin{array}{ll}7.9 & (36) \\
6.3 & (36) \\
6.1 & (33)\end{array}$ & $\begin{array}{ll}6.3 & (34) \\
5.9 & (33) \\
5.7 & (33)\end{array}$ & $\begin{array}{ll}6.7 & (29) \\
6.1 & (29) \\
4.6 & (30)\end{array}$ & $\begin{array}{ll}4.0 & (26) \\
6.8 & (25) \\
6.3 & (27)\end{array}$ & $\begin{array}{ll}5.7 & (25) \\
6.3 & (25) \\
7.2 & (25)\end{array}$ & $\begin{array}{ll}6.5 & (24) \\
7.8 & (25) \\
6.5 & (24)\end{array}$ \\
\hline $\begin{array}{rr}\text { ケミルミAC S - } & \text { 試料 } 1 \\
\text { プロラクチン } & \text { 試料 } 2 \\
& \text { 試料 } 3\end{array}$ & $\begin{array}{ll}4.2 & (6) \\
4.4 & (6) \\
6.8 & (6)\end{array}$ & $\begin{array}{ll}6.3 & (7) \\
8.0 & (7) \\
5.1 & (7)\end{array}$ & $\begin{array}{ll}6.0 & (10) \\
6.3 & (10) \\
6.8 & (10)\end{array}$ & $\begin{array}{ll}3.9 & (16) \\
4.5 & (16) \\
5.2 & (17)\end{array}$ & $\begin{array}{ll}7.1 & (15) \\
7.4 & (15) \\
6.8 & (15)\end{array}$ & $\begin{array}{ll}9.5 & (14) \\
6.3 & (14) \\
6.7 & (14)\end{array}$ \\
\hline $\begin{array}{ll}\text { アキシム } & \text { 試料1 } \\
\text { プロラクチン } & \text { 試料 } 2 \\
\text { ・ダイナパック } & \text { 試料 } 3\end{array}$ & $\begin{array}{l}- \\
- \\
-\end{array}$ & $\begin{array}{rr}37.1 & (5) \\
13.5 & (5) \\
9.5 & (5)\end{array}$ & $\begin{array}{ll}28.1 & (8) \\
24.1 & (8) \\
21.8 & (8)\end{array}$ & $\begin{array}{lr}7.0 & (10) \\
3.2 & (9) \\
4.9 & (9)\end{array}$ & $\begin{array}{ll}7.9 & (12) \\
3.2 & (11) \\
4.8 & (11)\end{array}$ & $\begin{array}{ll}4.9 & (11) \\
6.0 & (12) \\
4.6 & (11)\end{array}$ \\
\hline 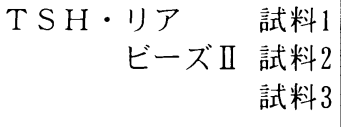 & $\begin{array}{ll}6.7 & (44) \\
5.6 & (43) \\
6.6 & (43)\end{array}$ & $\begin{array}{ll}8.7 & (26) \\
8.9 & (25) \\
7.0 & (25)\end{array}$ & $\begin{array}{ll}5.7 & (24) \\
4.4 & (23) \\
5.1 & (24)\end{array}$ & $\begin{aligned} 11.7 & (21) \\
5.2 & (20) \\
9.4 & (21)\end{aligned}$ & $\begin{array}{rr}11.2 & (21) \\
4.4 & (20) \\
4.6 & (21)\end{array}$ & $\begin{array}{ll}9.0 & (16) \\
4.1 & (16) \\
5.1 & (16)\end{array}$ \\
\hline $\begin{array}{rr}\text { スパック-S } & \text { 試料1 } \\
\mathrm{T} \text { S Hキット } & \text { 試料 } 2 \\
& \text { 試料 } 3\end{array}$ & $\begin{array}{ll}6.5 & (44) \\
6.1 & (43) \\
5.4 & (44)\end{array}$ & $\begin{array}{ll}7.8 & (36) \\
4.8 & (35) \\
5.6 & (36)\end{array}$ & $\begin{array}{ll}5.6 & (29) \\
5.2 & (30) \\
7.8 & (30)\end{array}$ & $\begin{array}{rr}14.2 & (20) \\
5.3 & (20) \\
4.0 & (19)\end{array}$ & $\begin{array}{ll}8.6 & (16) \\
5.1 & (16) \\
7.0 & (18)\end{array}$ & $\begin{array}{ll}3.8 & (10) \\
4.4 & (10) \\
4.0 & (10)\end{array}$ \\
\hline $\begin{array}{rr}\text { ケミルミA A S - } & \text { 試料 } 1 \\
\text { T S H II } & \text { 試料 } 2 \\
& \text { 試料 } 3\end{array}$ & $\begin{array}{l}- \\
- \\
-\end{array}$ & $\begin{array}{l}- \\
- \\
-\end{array}$ & $\begin{array}{ll}6.7 & (26) \\
7.0 & (26) \\
9.0 & (26)\end{array}$ & $\begin{array}{ll}6.2 & (32) \\
5.3 & (31) \\
6.6 & (32)\end{array}$ & $\begin{array}{ll}\text { 5. } 1 & (29) \\
\text { 4. } 6 & (30) \\
\text { 4. } 9 & (30)\end{array}$ & $\begin{array}{ll}5.5 & (28) \\
4.6 & (29) \\
3.7 & (29)\end{array}$ \\
\hline
\end{tabular}


（続き）

\begin{tabular}{|c|c|c|c|c|c|c|}
\hline キ & 第15回 & 16回 & 17回 & 18回 & 19回 & 20回 \\
\hline $\begin{array}{ll}\text { キシム T S H } & \text { 試料 } 1 \\
\text { ・ダイナパック } & \text { 試料 } 2 \\
& \text { 試料 } 3\end{array}$ & $\begin{array}{l}- \\
- \\
-\end{array}$ & $\begin{array}{ll}7.1 & (9) \\
4.8 & (8) \\
7.4 & (9)\end{array}$ & $\begin{array}{rr}9.0 & (8) \\
7.5 & (9) \\
12.1 & (9)\end{array}$ & \begin{tabular}{rr|}
12.4 & $(11)$ \\
9.0 & $(11)$ \\
12.1 & $(11)$
\end{tabular} & $\begin{array}{ll}5.1 & (11) \\
5.5 & (11) \\
4.5 & (11)\end{array}$ & $\begin{array}{ll}\text { 5. } 6 & (12) \\
4.8 & (12) \\
5.2 & (12)\end{array}$ \\
\hline $\begin{array}{rr}-3 \cdot \text { リア } & \text { 試料 } 1 \\
\text { ビーズ 試料 } 2 \\
\\
\text { 試料 } 3\end{array}$ & $\begin{array}{ll}6.8 & (41) \\
4.8 & (43) \\
4.2 & (42)\end{array}$ & $\begin{array}{ll}8.1 & (29) \\
4.8 & (28) \\
4.9 & (28)\end{array}$ & $\begin{array}{ll}7.9 & (30) \\
6.3 & (29) \\
6.4 & (30)\end{array}$ & $\begin{array}{ll}8.9 & (25) \\
5.0 & (24) \\
2.8 & (23)\end{array}$ & $\begin{array}{ll}8.8 & (26) \\
6.6 & (26) \\
5.8 & (26)\end{array}$ & $\begin{array}{ll}8.9 & (16) \\
3.1 & (16) \\
3.4 & (16)\end{array}$ \\
\hline $\begin{array}{rr}\text { ミルミA C S - } & \text { 試料 } 1 \\
\text { T } 3 & \text { 試料 } 2 \\
& \text { 試料 } 3\end{array}$ & $\begin{array}{ll}9.0 & (8) \\
5.3 & (8) \\
3.2 & (8)\end{array}$ & $\begin{array}{ll}1.0 & (15) \\
5.9 & (15) \\
6.7 & (15)\end{array}$ & $\begin{array}{ll}2.1 & (22) \\
5.0 & (21) \\
4.2 & (21)\end{array}$ & $\begin{array}{ll}8.3 & (28) \\
6.4 & (28) \\
4.6 & (27)\end{array}$ & $\begin{array}{ll}7.0 & (27) \\
6.5 & (28) \\
4.9 & (28)\end{array}$ & $\begin{array}{ll}8.2 & (25) \\
3.8 & (25) \\
2.2 & (26)\end{array}$ \\
\hline $\begin{array}{rr}\text { マレックス- } & \text { 試料 } 1 \\
\text { MAB フリー 試料 } 2 \\
\text { T } 3 \text { 試料 } 3\end{array}$ & $\begin{array}{ll}6.3 & (12) \\
3.1 & (14) \\
7.5 & (14)\end{array}$ & $\begin{array}{ll}9.2 & (69) \\
5.5 & (72) \\
5.9 & (69)\end{array}$ & $\begin{array}{ll}9.8 & (70) \\
5.8 & (70) \\
6.7 & (69)\end{array}$ & $\begin{array}{ll}1.4 & (55) \\
5.2 & (56) \\
6.1 & (56)\end{array}$ & $\begin{array}{ll}0.4 & (45) \\
4.9 & (46) \\
5.9 & (45)\end{array}$ & $\begin{array}{ll}6.4 & (35) \\
5.6 & (37) \\
5.1 & (36)\end{array}$ \\
\hline $\begin{array}{rlr}\text { ミルミA C S - } & \text { 試料 } 1 \\
\text { F T } 3 \text { II } & \text { 試料 } 2 \\
& \text { 試料 } 3\end{array}$ & $\begin{array}{l}- \\
- \\
-\end{array}$ & $\begin{array}{ll}9.1 & (15) \\
2.8 & (14) \\
2.6 & (15)\end{array}$ & $\begin{array}{ll}\text { 8. } 9 & (21) \\
\text { 4. } 0 & (21) \\
\text { 4. } 5 & (21)\end{array}$ & $\begin{array}{ll}\text { 8. } 3 & (30) \\
2.0 & (30) \\
\text { 3. } 6 & (30)\end{array}$ & $\begin{array}{ll}5.8 & (29) \\
1.9 & (30) \\
2.5 & (28)\end{array}$ & $\begin{array}{ll}\text { 4. } 9 & (26) \\
9.7 & (26) \\
9.8 & (26)\end{array}$ \\
\hline $\begin{array}{rr}\text { パック T } 4 & \text { 試料1 } \\
\text { R I Aキット 試料 } 2 \\
\\
& \text { 試料 } 3\end{array}$ & $\begin{array}{ll}7.4 & (36) \\
5.7 & (36) \\
6.0 & (37)\end{array}$ & $\begin{array}{ll}9.8 & (33) \\
5.4 & (33) \\
5.2 & (33)\end{array}$ & $\begin{array}{ll}9.2 & (31) \\
5.6 & (31) \\
3.6 & (31)\end{array}$ & $\begin{array}{ll}4.6 & (26) \\
4.3 & (24) \\
5.1 & (25)\end{array}$ & $\begin{array}{ll}10.3 & (23) \\
3.4 & (22) \\
3.9 & (22)\end{array}$ & $\begin{array}{ll}8.7 & (17) \\
7.2 & (17) \\
4.8 & (16)\end{array}$ \\
\hline $\begin{array}{rr}\text { ミルミAC S - 試料 } 1 \\
\mathrm{~T} 4 \text { 試料 } 2 \\
& \text { 試料 } 3\end{array}$ & $\begin{array}{rr}13.9 & (10) \\
6.3 & (9) \\
4.5 & (9)\end{array}$ & $\begin{array}{ll}9.7 & (17) \\
3.6 & (16) \\
3.7 & (16)\end{array}$ & $\begin{array}{ll}7.8 & (22) \\
4.1 & (22) \\
4.1 & (21)\end{array}$ & $\begin{array}{ll}0.2 & (28) \\
6.0 & (28) \\
5.5 & (28)\end{array}$ & $\begin{array}{ll}7.5 & (27) \\
4.3 & (27) \\
3.5 & (26)\end{array}$ & $\begin{array}{ll}9.0 & (26) \\
4.4 & (26) \\
4.1 & (27)\end{array}$ \\
\hline 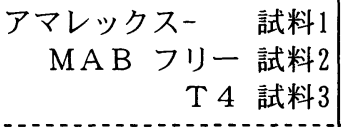 & $\begin{array}{ll}6.5 & (18) \\
7.8 & (20) \\
6.8 & (19)\end{array}$ & $\begin{array}{ll}9.4 & (72) \\
6.1 & (71) \\
6.0 & (70)\end{array}$ & 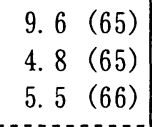 & $\begin{array}{ll}7.8 & (57) \\
6.7 & (55) \\
9.2 & (56)\end{array}$ & $\begin{array}{ll}6.8 & (47) \\
3.6 & (46) \\
6.0 & (47)\end{array}$ & $\begin{array}{ll}7.9 & (35) \\
7.0 & (37) \\
5.2 & (36)\end{array}$ \\
\hline $\begin{array}{rr}\text { ミルミA C S - } & \text { 試料 } 1 \\
\text { F T } 4 & \text { 試料 } 2 \\
& \text { 試料 } 3\end{array}$ & $\begin{aligned} 27.8 & (9) \\
8.3 & (8) \\
14.6 & (8)\end{aligned}$ & $\begin{aligned} 14.6 & (17) \\
7.1 & (17) \\
9.8 & (16)\end{aligned}$ & $\begin{array}{ll}\text { 13. } 3 & (24) \\
\text { 7. } 4 & (23) \\
\text { 8. } 2 & (23)\end{array}$ & $\begin{array}{ll}9.6 & (31) \\
4.2 & (30) \\
6.2 & (30)\end{array}$ & $\begin{array}{ll}11.7 & (31) \\
6.0 & (31) \\
6.5 & (31)\end{array}$ & $\begin{array}{ll}11.3 & (27) \\
6.7 & (28) \\
6.2 & (26)\end{array}$ \\
\hline $\begin{array}{ll}\text { キシム } & \text { 試料1 } \\
\text { フリーT } 4 & \text { 試料2 } \\
\text { ・ダイナパック } & \text { 試料 } 3\end{array}$ & $\begin{array}{l}- \\
- \\
-\end{array}$ & $\begin{aligned} 16.0 & (8) \\
6.9 & (8) \\
4.7 & (7)\end{aligned}$ & $\begin{aligned} 11.1 & (7) \\
5.4 & (7) \\
1.7 & (6)\end{aligned}$ & $\begin{array}{rr}22.6 & (10) \\
28.9 & (10) \\
24.5 & (9)\end{array}$ & $\begin{array}{ll}14.2 & (11) \\
7.3 & (10) \\
6.3 & (10)\end{array}$ & $\begin{array}{lr}5.7 & (9) \\
4.3 & (10) \\
6.7 & (10)\end{array}$ \\
\hline \begin{tabular}{l|} 
試料1 \\
試料2 \\
試料3
\end{tabular} & $\begin{array}{ll}4.5 & (14) \\
6.4 & (15) \\
7.4 & (14)\end{array}$ & $\begin{array}{ll}5.8 & (14) \\
4.0 & (13) \\
7.4 & (14)\end{array}$ & $\begin{array}{ll}3.6 & (13) \\
5.9 & (14) \\
6.0 & (15)\end{array}$ & $\begin{array}{ll}\text { 6. } 1 & (15 \\
\text { 8. } 5 & (15 \\
\text { 7. } 0 & (14\end{array}$ & $\begin{array}{ll}3.6 & (14) \\
4.4 & (13) \\
4.1 & (14)\end{array}$ & $\begin{array}{ll}4.7 & (12) \\
2.4 & (12) \\
3.3 & (12)\end{array}$ \\
\hline $\begin{array}{l}\text { 試料1 } \\
\text { 試料2 } \\
\text { 試料 } 3\end{array}$ & $\begin{array}{ll}4.9 & (29) \\
5.2 & (31) \\
6.0 & (30)\end{array}$ & $\begin{array}{ll}4.1 & (18) \\
3.6 & (19) \\
4.5 & (19)\end{array}$ & $\begin{array}{ll}\text { 4. } 3 & (21) \\
\text { 4. } 5 & (21) \\
\text { 4. } 7 & (21)\end{array}$ & $\begin{array}{ll}5.6 & (16) \\
4.2 & (16) \\
5.1 & (16)\end{array}$ & $\begin{array}{ll}8.1 & (13) \\
7.7 & (13) \\
5.1 & (12)\end{array}$ & $\begin{array}{ll}4.4 & (10) \\
4.4 & (10) \\
7.3 & (11)\end{array}$ \\
\hline $\begin{array}{lr}\text { カルシトニン } & \text { 試料 } 1 \\
\text { R I A「ミツビシ」 } & \text { 試料 } 2 \\
& \text { 試料 } 3\end{array}$ & $\begin{array}{l}- \\
- \\
-\end{array}$ & $\begin{array}{ll}5.1 & (9) \\
5.3 & (9) \\
4.8 & (9)\end{array}$ & $\begin{array}{ll}\text { 5. } 0 & (10) \\
2 . & 1(10) \\
2.8 & (10)\end{array}$ & $\begin{array}{rr}4.3 & (11) \\
5.4 & (11) \\
11.2 & (10)\end{array}$ & $\begin{array}{ll}11.7 & (11 \\
4.9 & (11 \\
6.0 & (10\end{array}$ & $\begin{array}{ll}9.4 & (12) \\
4.6 & (11) \\
8.1 & (11)\end{array}$ \\
\hline $\begin{array}{ll}\text { インシュリン } & \text { 試料 } 1 \\
\text { リア・ビーズ II } & \text { 試料 } 2 \\
& \text { 試料 } 3\end{array}$ & $\begin{array}{ll}4.9 & (61) \\
4.1 & (60) \\
4.1 & (62)\end{array}$ & $\begin{array}{ll}\text { 4. } 1 & (51 \\
4.7 & (51 \\
3.9 & (50\end{array}$ & $\begin{array}{ll}\text { 4. } 4 & (48 \\
\text { 3. } 2 & (48 \\
\text { 3. } 4 & (47\end{array}$ & $\begin{array}{ll}\text { 4. } 3 & (42 \\
\text { 3. } 8 & (40 \\
\text { 3. } 9 & (40\end{array}$ & $\begin{array}{ll}\text { 4. } 1 & (37 \\
3.4 & (38 \\
4.3 & (39\end{array}$ & $\begin{array}{ll}4.1 & (32) \\
2.7 & (33) \\
3.3 & (33)\end{array}$ \\
\hline
\end{tabular}


（続き）

\begin{tabular}{|c|c|c|c|c|c|c|c|}
\hline キ & & 第15回 & 第16回 & 第17回 & 第18回 & 第19回 & 第20回 \\
\hline $\begin{array}{l}\text { b ビーズ } \\
\text { インシュリン } \\
\text { “栄研” }\end{array}$ & $\begin{array}{l}\text { 試料1 } \\
\text { 試料 } 2 \\
\text { 試料 } 3\end{array}$ & $\begin{aligned} 12.1 & (14) \\
3.3 & (14) \\
6.3 & (14)\end{aligned}$ & $\begin{aligned} 15.5 & (13) \\
6.0 & (12) \\
10.2 & (13)\end{aligned}$ & $\begin{aligned} 11.9 & (15) \\
11.0 & (15) \\
6.1 & (14)\end{aligned}$ & $\begin{aligned} 10.2 & (11) \\
4.7 & (10) \\
5.2 & (10)\end{aligned}$ & $\begin{aligned} 10.9 & (11) \\
5.3 & (11) \\
2.8 & (11)\end{aligned}$ & $\begin{array}{rr}21.6 & (9) \\
12.0 & (10) \\
8.4 & (10)\end{array}$ \\
\hline $\begin{array}{l}\text { V-ペプチド } \\
\text { キット「第一」III }\end{array}$ & $\begin{array}{l}\text { 試料 } 1 \\
\text { 試料 } 2 \\
\text { 試料 } 3\end{array}$ & $\begin{aligned} 10.3 & (56) \\
9.9 & (54) \\
9.9 & (57)\end{aligned}$ & $\begin{aligned} 10.1 & (44) \\
8.5 & (43) \\
8.6 & (43)\end{aligned}$ & $\begin{array}{ll}9.3 & (45) \\
8.2 & (45) \\
6.9 & (44)\end{array}$ & $\begin{aligned} 13.2 & (45) \\
6.2 & (44) \\
6.4 & (43)\end{aligned}$ & $\begin{array}{ll}9.8 & (35) \\
5.0 & (37) \\
6.9 & (38)\end{array}$ & $\begin{array}{ll}7.2 & (34) \\
5.3 & (33) \\
6.9 & (34)\end{array}$ \\
\hline $\begin{array}{r}\text { ¿ーペプチドリア } \\
\text { シオノギ }\end{array}$ & $\begin{array}{l}\text { 試料1 } \\
\text { 試料 } 2 \\
\text { 試料 } 3\end{array}$ & $\begin{aligned} 14.0 & (45) \\
7.5 & (44) \\
9.6 & (42)\end{aligned}$ & $\begin{aligned} 13.1 & (40) \\
12.7 & (41) \\
9.0 & (40)\end{aligned}$ & $\begin{array}{ll}8.7 & (31) \\
6.1 & (31) \\
7.8 & (33)\end{array}$ & $\begin{aligned} 11.5 & (27) \\
7.3 & (27) \\
16.2 & (27)\end{aligned}$ & $\begin{array}{ll}7.3 & (19) \\
6.6 & (19) \\
7.7 & (19)\end{array}$ & $\begin{array}{ll}4.8 & (20) \\
7.6 & (21) \\
7.3 & (21)\end{array}$ \\
\hline $\begin{array}{r}\text { "ルカゴンキット } \\
\text { 「第一」」 }\end{array}$ & $\begin{array}{l}\text { 試料 } 1 \\
\text { 試料 } 2 \\
\text { 試料 } 3\end{array}$ & $\begin{array}{rr}5.8 & (11) \\
9.7 & (13) \\
10.1 & (13) \\
\end{array}$ & $\begin{array}{rr}11.3 & (12) \\
21.3 & (12) \\
9.4 & (12)\end{array}$ & $\begin{array}{ll}7.7 & (12) \\
7.9 & (12) \\
9.5 & (12)\end{array}$ & $\begin{array}{ll}11.7 & (12) \\
13.8 & (12) \\
18.4 & (12)\end{array}$ & $\begin{array}{ll}12.8 & (12) \\
11.4 & (12) \\
10.4 & (12)\end{array}$ & $\begin{array}{rr}13.0 & (13) \\
11.9 & (13) \\
8.8 & (12) \\
\end{array}$ \\
\hline $\begin{array}{r}\text { ストリン・リア } \\
\text { キットII }\end{array}$ & $\begin{array}{l}\text { 試料 } 1 \\
\text { 試料 } 2 \\
\text { 試料 } 3\end{array}$ & $\begin{aligned} 14.0 & (31) \\
8.4 & (30) \\
9.7 & (28)\end{aligned}$ & $\begin{aligned} 10.5 & (32) \\
7.6 & (31) \\
6.6 & (31)\end{aligned}$ & $\begin{array}{ll}8.9 & (26) \\
6.8 & (28) \\
6.9 & (28)\end{array}$ & $\begin{aligned} 11.2 & (25) \\
6.9 & (25) \\
9.8 & (22)\end{aligned}$ & $\begin{aligned} 14.0 & (23) \\
7.9 & (22) \\
5.8 & (23)\end{aligned}$ & $\begin{aligned} 15.7 & (23) \\
6.4 & (22) \\
7.6 & (23)\end{aligned}$ \\
\hline 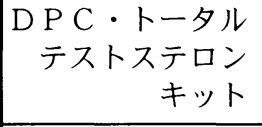 & $\begin{array}{l}\text { 試料1 } \\
\text { 試料 } 2 \\
\text { 試料 } 3\end{array}$ & $\begin{array}{ll}7.5 & (21) \\
6.3 & (20) \\
5.9 & (20) \\
\end{array}$ & $\begin{array}{rr}11.0 & (25) \\
5.9 & (24) \\
5.9 & (25) \\
\end{array}$ & $\begin{array}{rr}11.0 & (22) \\
5.2 & (23) \\
6.1 & (23) \\
\end{array}$ & $\begin{array}{ll}7.9 & (23) \\
3.7 & (24) \\
4.0 & (23)\end{array}$ & $\begin{array}{ll}9.5 & (19) \\
5.2 & (20) \\
7.2 & (21) \\
\end{array}$ & $\begin{array}{ll}9.8 & (18) \\
4.7 & (19) \\
5.4 & (17)\end{array}$ \\
\hline $\begin{array}{l}\text { D P C ・エストラ } \\
\text { ジオールキット }\end{array}$ & $\begin{array}{l}\text { 試料 } 1 \\
\text { 試料 } 2 \\
\text { 試料 } 3\end{array}$ & $\begin{aligned} 14.3 & (24) \\
14.1 & (24) \\
8.3 & (24)\end{aligned}$ & $\begin{aligned} 15.9 & (27) \\
9.0 & (27) \\
6.0 & (27)\end{aligned}$ & $\begin{aligned} 10.6 & (25) \\
6.6 & (25) \\
7.1 & (27)\end{aligned}$ & $\begin{aligned} 14.4 & (25) \\
9.4 & (27) \\
6.9 & (26)\end{aligned}$ & $\begin{array}{rr}12.5 & (23) \\
6.2 & (24) \\
4.9 & (24)\end{array}$ & $\begin{array}{ll}9.6 & (19) \\
7.8 & (21) \\
2.9 & (18)\end{array}$ \\
\hline $\begin{array}{c}\text { ケミルミAＣ S - } \\
\text { エストラジオ } \\
\text { ールキット6 }\end{array}$ & $\begin{array}{l}\text { 試料 } 1 \\
\text { 試料 } 2 \\
\text { 試料 } 3\end{array}$ & $\begin{array}{l}- \\
- \\
-\end{array}$ & - & - & $\begin{array}{l}- \\
- \\
-\end{array}$ & $\begin{array}{rr}13.0 & (6) \\
8.8 & (6) \\
3.6 & (6) \\
\end{array}$ & $\begin{array}{lr}6.3 & (10) \\
3.6 & (9) \\
3.6 & (10)\end{array}$ \\
\hline $\begin{array}{r}\mathrm{D} \text { P C・プロゲス } \\
\text { テロンキット }\end{array}$ & $\begin{array}{l}\text { 試料 } 1 \\
\text { 試料 } 2 \\
\text { 試料 } 3\end{array}$ & $\begin{array}{rr}11.0 & (25) \\
3.7 & (24) \\
6.6 & (25)\end{array}$ & $\begin{array}{ll}8.6 & (28) \\
5.2 & (27) \\
5.4 & (28)\end{array}$ & $\begin{array}{ll}9.1 & (26) \\
8.0 & (26) \\
7.2 & (26)\end{array}$ & $\begin{array}{ll}5.5 & (23) \\
5.1 & (23) \\
6.0 & (24)\end{array}$ & $\begin{array}{rr}10.8 & (27) \\
6.2 & (27) \\
5.2 & (27)\end{array}$ & $\begin{array}{ll}6.6 & (25) \\
4.9 & (24) \\
6.7 & (25)\end{array}$ \\
\hline $\begin{array}{l}\text { ケミルミ- A C S } \\
\text { プロゲステロン } \\
\text { キット }\end{array}$ & $\begin{array}{l}\text { 試料 } 1 \\
\text { 試料 } 2 \\
\text { 試料 } 3\end{array}$ & $\begin{array}{l}- \\
- \\
-\end{array}$ & $\begin{array}{ll}8.9 & (2) \\
2.3 & (2) \\
4.7 & (2)\end{array}$ & $\begin{array}{rr}14.4 & (5) \\
8.1 & (5) \\
12.0 & (5)\end{array}$ & $\begin{array}{lr}10.6 & (10) \\
11.2 & (10) \\
12.5 & (9)\end{array}$ & $\begin{array}{rr}6.4 & (8) \\
16.0 & (9) \\
8.1 & (8)\end{array}$ & $\begin{aligned} 5.4 & (10) \\
11.8 & (11) \\
5.9 & (11)\end{aligned}$ \\
\hline $\begin{array}{r}\text { スパック-S } \\
\text { アルドステロン } \\
\text { キット }\end{array}$ & $\begin{array}{l}\text { 試料 } 1 \\
\text { 試料 } 2 \\
\text { 試料 } 3\end{array}$ & $\begin{array}{ll}\text { 8. } 2 & (20) \\
7.0 & (20) \\
7.3 & (20)\end{array}$ & $\begin{array}{rr}11.6 & (23) \\
9.1 & (21) \\
9.3 & (22)\end{array}$ & $\begin{array}{ll}8.0 & (25) \\
8.2 & (25) \\
7.2 & (25)\end{array}$ & $\begin{array}{ll}7.2 & (27) \\
4.6 & (28) \\
5.9 & (27)\end{array}$ & $\begin{array}{ll}4.5 & (24) \\
4.7 & (25) \\
5.7 & (24)\end{array}$ & $\begin{array}{ll}9.4 & (31) \\
7.5 & (31) \\
7.9 & (30)\end{array}$ \\
\hline $\begin{array}{r}\text { アルドステロン } \\
\text { リアキッットII }\end{array}$ & $\begin{array}{l}\text { 試料 } 1 \\
\text { 試料 } 2 \\
\text { 試料 } 3\end{array}$ & $\begin{aligned} 14.8 & (24) \\
6.5 & (22) \\
7.0 & (24)\end{aligned}$ & $\begin{array}{rr}11.8 & (19) \\
6.2 & (19) \\
6.1 & (19)\end{array}$ & $\begin{array}{ll}9.8 & (20) \\
9.4 & (20) \\
9.3 & (20)\end{array}$ & $\begin{aligned} 13.8 & (17) \\
9.7 & (18) \\
8.4 & (17)\end{aligned}$ & $\begin{aligned} 12.1 & (17) \\
6.8 & (15) \\
4.2 & (16)\end{aligned}$ & $\begin{array}{ll}10.8 & (16) \\
11.9 & (17) \\
10.0 & (16)\end{array}$ \\
\hline $\begin{array}{r}\text { スパック-S } \\
\text { コルチゾール } \\
\text { キット }\end{array}$ & $\begin{array}{l}\text { 試料1 } \\
\text { 試料 } 2 \\
\text { 試料 } 3\end{array}$ & $\begin{aligned} 13.4 & (19) \\
8.2 & (19) \\
8.0 & (19)\end{aligned}$ & $\begin{aligned} 10.0 & (17) \\
5.2 & (17) \\
5.0 & (16)\end{aligned}$ & $\begin{aligned} 13.3 & (13) \\
7.0 & (13) \\
10.3 & (14)\end{aligned}$ & $\begin{aligned} 11.9 & (13) \\
9.3 & (13) \\
7.9 & (14)\end{aligned}$ & $\begin{array}{rr}12.7 & (13) \\
4.2 & (13) \\
4.6 & (13)\end{array}$ & $\begin{array}{ll}8.9 & (11) \\
4.5 & (11) \\
5.2 & (11)\end{array}$ \\
\hline $\begin{array}{r}\text { ガンマー・コート } \\
\text { コーチゾール }\end{array}$ & $\begin{array}{l}\text { 試料1 } \\
\text { 試料2 } \\
\text { 試料 } 3\end{array}$ & $\begin{array}{ll}9.3 & (16) \\
6.5 & (16) \\
4.2 & (16)\end{array}$ & $\begin{array}{ll}9.5 & (17) \\
5.7 & (17) \\
6.9 & (17)\end{array}$ & $\begin{array}{ll}8.9 & (15) \\
8.7 & (14) \\
7.8 & (14)\end{array}$ & $\begin{aligned} 9.8 & (13) \\
10.0 & (14) \\
8.3 & (13)\end{aligned}$ & $\begin{array}{ll}7.3 & (12) \\
6.2 & (13) \\
4.4 & (13)\end{array}$ & $\begin{array}{ll}5.1 & (11) \\
8.2 & (12) \\
7.8 & (11)\end{array}$ \\
\hline
\end{tabular}


（続き）

\begin{tabular}{|c|c|c|c|c|c|c|c|}
\hline 卜名 & & 第15回 & 第16回 & 第17回 & 第18回 & 第19回 & 第20回 \\
\hline $\begin{array}{l}\mathrm{P} \mathrm{C} \cdot \\
\text { D H E A-S } \\
\text { キット }\end{array}$ & $\begin{array}{l}\text { 試料1 } \\
\text { 試料2 } \\
\text { 試料 } 3\end{array}$ & $\begin{array}{l}- \\
- \\
-\end{array}$ & $\begin{array}{l}- \\
- \\
-\end{array}$ & $\begin{array}{rr}14.5 & (6) \\
8.5 & (6) \\
23.0 & (6)\end{array}$ & $\begin{array}{rr}11.9 & (7) \\
8.3 & (7) \\
9.0 & (7)\end{array}$ & $\begin{array}{rr}10.8 & (7) \\
10.0 & (7) \\
4.0 & (6)\end{array}$ & $\begin{array}{rr}12.1 & (10) \\
6.0 & (9) \\
3.3 & (9)\end{array}$ \\
\hline $\begin{array}{l}\text { ニン I R MA } \\
\text { 「第一」 }\end{array}$ & $\begin{array}{l}\text { 試料1 } \\
\text { 試料2 } \\
\text { 試料 } 3\end{array}$ & $\begin{array}{l}- \\
- \\
-\end{array}$ & $\begin{array}{rr}6.7 & (5) \\
4.2 & (5) \\
11.3 & (5)\end{array}$ & $\begin{array}{ll}6.1 & (28) \\
6.4 & (28) \\
6.6 & (28)\end{array}$ & $\begin{array}{ll}5.7 & (17) \\
3.7 & (17) \\
3.9 & (17)\end{array}$ & $\begin{array}{ll}4.6 & (16) \\
5.2 & (16) \\
3.1 & (16)\end{array}$ & $\begin{array}{ll}5.4 & (17) \\
6.2 & (17) \\
7.8 & (17)\end{array}$ \\
\hline $\begin{array}{l}\text { ヤップ I g E } \\
\text { F E I A }\end{array}$ & $\begin{array}{l}\text { 試料1 } \\
\text { 試料2 } \\
\text { 試料3 }\end{array}$ & $\begin{array}{rr}3.6 & (5) \\
8.5 & (5) \\
11.2 & (5)\end{array}$ & $\begin{array}{ll}4.3 & (7) \\
6.1 & (7) \\
8.7 & (7)\end{array}$ & $\begin{array}{ll}9.3 & (7) \\
9.0 & (8) \\
6.7 & (8)\end{array}$ & $\begin{array}{ll}3.5 & (12) \\
4.6 & (13) \\
8.2 & (12)\end{array}$ & $\begin{array}{ll}7.8 & (13) \\
5.1 & (13) \\
4.7 & (13)\end{array}$ & $\begin{array}{ll}7.4 & (12) \\
7.0 & (13) \\
8.5 & (13)\end{array}$ \\
\hline $\begin{aligned} \text { ミルミ } & \mathrm{ACS} \\
& -\mathrm{I} \mathrm{g} \mathrm{E}\end{aligned}$ & $\begin{array}{l}\text { 試料1 } \\
\text { 試料2 } \\
\text { 試料3 }\end{array}$ & $\left.\begin{array}{rr}3.6 & (5) \\
8.5 & (5) \\
11.2 & (5)\end{array}\right]$ & $\begin{array}{ll}4.3 & (7) \\
6.1 & (7) \\
8.7 & (7)\end{array}$ & $\begin{array}{ll}9.3 & (7) \\
9.0 & (8) \\
6.7 & (8)\end{array}$ & $\begin{array}{ll}3.5 & (12) \\
4.6 & (13) \\
8.2 & (12)\end{array}$ & $\left.\begin{array}{rr}5.1 & (10) \\
2.4 & (9) \\
2.9 & (9)\end{array}\right]$ & $\begin{array}{lr}5.1 & (10) \\
2.4 & (9) \\
2.9 & (9)\end{array}$ \\
\hline $\begin{array}{l}\text { ミルミAC C S- } \\
\text { ジゴキシン II }\end{array}$ & $\begin{array}{l}\text { 試料1 } \\
\text { 試料2 } \\
\text { 試料 } 3\end{array}$ & $\begin{array}{l}- \\
- \\
-\end{array}$ & $\begin{aligned} 10.2 & (9) \\
5.8 & (9) \\
2.3 & (8)\end{aligned}$ & $\begin{array}{ll}9.7 & (12) \\
4.2 & (12) \\
3.9 & (12)\end{array}$ & $\begin{aligned} 11.2 & (12) \\
4.1 & (11) \\
3.7 & (11)\end{aligned}$ & $\begin{array}{ll}8.4 & (12) \\
4.5 & (13) \\
4.0 & (12)\end{array}$ & $\begin{array}{ll}8.8 & (11) \\
5.4 & (12) \\
3.9 & (12)\end{array}$ \\
\hline $\begin{array}{l}\text { キシム } \\
\text { ジゴキシン } \\
\text { タイイバック・NPT }\end{array}$ & $\begin{array}{l}\text { 試料1 } \\
\text { 試料2 } \\
\text { 試料 } 3\end{array}$ & $\begin{array}{l}- \\
- \\
-\end{array}$ & $\begin{array}{l}- \\
- \\
-\end{array}$ & $\begin{array}{l}- \\
- \\
-\end{array}$ & $\begin{aligned} 21.7 & (7) \\
3.1 & (7) \\
3.4 & (7)\end{aligned}$ & $\left.\begin{array}{rr}12.0 & (10) \\
5.3 & (13) \\
2.3 & (13)\end{array}\right]$ & $\begin{aligned} 10.5 & (11) \\
3.9 & (12) \\
3.9 & (12)\end{aligned}$ \\
\hline $\begin{array}{r}\alpha \text {-フェト・リア } \\
\text { ビーズ }\end{array}$ & $\begin{array}{l}\text { 試料1 } \\
\text { 試料2 } \\
\text { 試料3 }\end{array}$ & $\begin{array}{l}- \\
- \\
-\end{array}$ & $\begin{array}{ll}7.9 & (47) \\
6.0 & (46) \\
9.4 & (48)\end{array}$ & $\begin{array}{ll}8.4 & (41) \\
6.6 & (40) \\
9.2 & (42)\end{array}$ & $\begin{array}{ll}6.3 & (36) \\
5.8 & (37) \\
5.4 & (35)\end{array}$ & $\begin{array}{ll}7.0 & (31) \\
7.1 & (32) \\
9.1 & (32)\end{array}$ & $\begin{array}{ll}7.2 & (29) \\
7.5 & (29) \\
8.7 & (29)\end{array}$ \\
\hline $\begin{array}{l}\text { キシム A } \\
\text { ・ダイナ }\end{array}$ & $\begin{array}{l}\text { 試料1 } \\
\text { 試料 } 2 \\
\text { 試料 } 3\end{array}$ & $\begin{array}{l}- \\
- \\
-\end{array}$ & $\begin{array}{ll}5.0 & (8) \\
5.6 & (8) \\
6.4 & (8)\end{array}$ & $\begin{array}{rr}9.1 & (9) \\
8.6 & (9) \\
12.7 & (9)\end{array}$ & $\begin{aligned} 8.0 & (10) \\
10.7 & (11) \\
12.0 & (11)\end{aligned}$ & $\begin{array}{ll}4.5 & (13) \\
6.8 & (13) \\
7.6 & (13)\end{array}$ & $\begin{array}{ll}5.6 & (12) \\
7.8 & (12) \\
8.6 & (12)\end{array}$ \\
\hline $\begin{array}{r}\text { ミルミA C S - } \\
\text { A F P }\end{array}$ & $\begin{array}{l}\text { 試料1 } \\
\text { 試料2 } \\
\text { 試料 } 3\end{array}$ & $\begin{array}{l}- \\
- \\
-\end{array}$ & $\begin{array}{ll}5.6 & (6) \\
3.1 & (6) \\
5.3 & (6)\end{array}$ & $\begin{array}{ll}6.8 & (7) \\
2.8 & (7) \\
2.3 & (7)\end{array}$ & $\begin{array}{lr}3.2 & (9) \\
3.9 & (10) \\
3.4 & (10)\end{array}$ & $\begin{array}{ll}4.0 & (10) \\
1.5 & (10) \\
\text { 7. } 0 & (11)\end{array}$ & $\begin{array}{ll}\text { 3. } 9 & (10) \\
5.1 & (10) \\
5.3 & (10)\end{array}$ \\
\hline 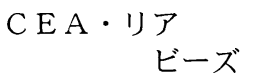 & $\begin{array}{l}\text { 試料1 } \\
\text { 試料 } 2\end{array}$ & $\begin{array}{ll}8.1 & (71) \\
5.5 & (68)\end{array}$ & $\begin{array}{ll}6.6 & (59) \\
6.4 & (60)\end{array}$ & $\begin{array}{rr}10.4 & (55) \\
6.2 & (55)\end{array}$ & $\begin{array}{ll}6.8 & (42) \\
5.8 & (44)\end{array}$ & $\begin{array}{ll}9.6 & (38) \\
5.8 & (38)\end{array}$ & $\begin{aligned} 17.2 & (28) \\
7.7 & (30)\end{aligned}$ \\
\hline 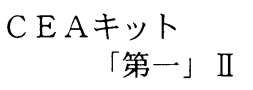 & $\begin{array}{l}\text { 試料1 } \\
\text { 試料 } 2\end{array}$ & $\begin{aligned} 10.1 & (28) \\
5.5 & (29)\end{aligned}$ & $\begin{array}{r}12.9(23) \\
7.5(24)\end{array}$ & $\begin{aligned} 13.1 & (20) \\
5.6 & (20)\end{aligned}$ & $\begin{array}{l}3.8(13) \\
5.0(13)\end{array}$ & $\begin{array}{rr}11.3 & (13) \\
3.8 & (11)\end{array}$ & $\begin{array}{l}9.4(11) \\
6.8(11)\end{array}$ \\
\hline $\begin{array}{l}\text { キシム C E A } \\
\text { •ダイナパック }\end{array}$ & $\begin{array}{l}\text { 試料1 } \\
\text { 試料 } 2\end{array}$ & - & $\begin{array}{rr}10.2 & (9) \\
6.6 & (9)\end{array}$ & $\begin{array}{l}7.3 \text { (13) } \\
5.4(13)\end{array}$ & $\begin{array}{r}10.5(15) \\
9.3(15)\end{array}$ & $\begin{array}{ll}4.9 & (15) \\
4.2 & (14)\end{array}$ & $\begin{array}{ll}\text { 7. } 5 & (12) \\
5.3(12)\end{array}$ \\
\hline $\begin{array}{r}\text { ミルミA C S } \\
- \text { C E A }\end{array}$ & $\begin{array}{l}\text { 試料1 } \\
\text { 試料2 }\end{array}$ & - & - & $\begin{array}{ll}9.4 & (3) \\
5.2 & (3)\end{array}$ & $\begin{array}{ll}4.5 & (7) \\
6.6 & (7)\end{array}$ & $\begin{array}{ll}\text { 4. } 5 & (10) \\
5.9 & (10)\end{array}$ & $\begin{array}{ll}5.0 & (9) \\
7.5 & (10)\end{array}$ \\
\hline $\begin{array}{l}\text { プロリフィゲン } \\
\text { T P A-M「第一」 }\end{array}$ & $\begin{array}{l}\text { 試料1 } \\
\text { 試料2 }\end{array}$ & $\begin{array}{l}- \\
-\end{array}$ & - & - & $\begin{array}{c}9.0(30) \\
-\end{array}$ & $\begin{array}{c}6.8(31) \\
-\end{array}$ & $\begin{array}{c}\text { 12. } 7(32) \\
-\end{array}$ \\
\hline $\begin{array}{l}\text { ントコア } \\
\text { CA } 125 \text { II }\end{array}$ & $\begin{array}{l}\text { 試料1 } \\
\text { 試料2 }\end{array}$ & $\begin{array}{ll}6.7 & (59) \\
6.0 & (58)\end{array}$ & $\begin{array}{ll}6.5 & (45) \\
4.7 & (45)\end{array}$ & $\begin{array}{ll}6.8 & (47) \\
5.2 & (46)\end{array}$ & $\begin{array}{ll}8.1 & (44) \\
4.5 & (42)\end{array}$ & $\begin{array}{ll}4.1 & (37) \\
3.8 & (40)\end{array}$ & $\begin{array}{ll}4.7 & (35) \\
4.2 & (34)\end{array}$ \\
\hline $\begin{array}{l}\text { ボールエルザ・ } \\
\text { C A } 125 \text { II ・キット }\end{array}$ & $\begin{array}{l}\text { 試料1 } \\
\text { 試料2 }\end{array}$ & $\begin{array}{ll}5.2 & (12) \\
7.0 & (13)\end{array}$ & $\begin{array}{lr}4.7 & (9) \\
9.4 & (10)\end{array}$ & $\begin{array}{ll}5.1 & (10) \\
7.5 & (10)\end{array}$ & $\begin{array}{ll}7.3 & (12) \\
3.8 & (11)\end{array}$ & $\begin{array}{ll}6.1 & (11) \\
8.1 & (11)\end{array}$ & $\begin{array}{ll}7.7 & (11) \\
8.6 & (11)\end{array}$ \\
\hline
\end{tabular}


（続き）

\begin{tabular}{|c|c|c|c|c|c|c|}
\hline キット名 & 15回 & 6回 & 7回 & 第18回 & 第19回 & 第20回 \\
\hline キシム C A 125 試料 1 & - & - & . & $4.8 \quad(8)$ & 7. 6 (11) & 7. $2(11)$ \\
\hline •ダイナパック 試料2 & - & - & 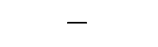 & 4. $4 \quad(7)$ & 7. $5(11)$ & 5. 2 (11) \\
\hline ントコア & $15.3(80)$ & $12.6(68)$ & $10.5(63)$ & 17. $1(60)$ & $12.3(46)$ & 14. 4(39) \\
\hline C A $19-9$ 試料 2 & $12.9(82)$ & $10.1 \quad(72)$ & 8. $0(63)$ & $10.5(60)$ & $8.5(45)$ & $10.5(39)$ \\
\hline キシム C A 19-9試料 1 & - & 27.5 (4) & 5. $7 \quad(6)$ & 6.4 (11) & $12.0(13)$ & $12.0 \quad(9)$ \\
\hline ・ダイナパック 試料2 & - & 19. $4 \quad(4)$ & 8. $2 \quad(7)$ & $3.3(12)$ & 7. 8 (13) & 6. $9(10)$ \\
\hline 「ミルミ & - & - & - & 8. 3 & 14.6 (11) & $10.7(10)$ \\
\hline C A $19-9$ & - & - & - & 4. $0 \quad(5)$ & $6.3(10)$ & $3.5(10)$ \\
\hline セントコア & $6.1(33)$ & $10.0 \quad(29)$ & 8. $3(27)$ & $11.1(26)$ & $12.7(26)$ & 10. $2(26)$ \\
\hline C A $15-3$ & 7. $0(34)$ & 8. $7(31)$ & $9.8(29)$ & 10.2(26) & 7. $1 \quad(25)$ & 6. $2(24)$ \\
\hline P A P “栄研” & 7. 9 (27) & 4. $8(22)$ & 5. $1(17)$ & $6.9(18)$ & $3.3(13)$ & 5. $3(10)$ \\
\hline+2 & $9.8(16)$ & $9.5(15)$ & 5. $3(14)$ & $6.8(15)$ & 8. $4(12)$ & $6.5 \quad(9)$ \\
\hline タンデム P S A & 7. $0 \quad(8)$ & $5.6 \quad(7)$ & $14.4 \quad(6)$ & 7. $4(10)$ & $11.2(14)$ & 5. 6 (13) \\
\hline 斗2 & $2.7 \quad(7)$ & 2. $7 \quad(6)$ & $3.6 \quad(6)$ & $6.4(11)$ & $5.3(13)$ & 3. $2(12)$ \\
\hline$\beta_{2}-\mathrm{MG}$ Gア & 7. $6(40)$ & $5.8(29)$ & $6.3(25)$ & $11.5(23)$ & 8. $0(21)$ & $6.0(17)$ \\
\hline ギ 試料2 & $4.5(37)$ & 4. $2(29)$ & $3.9(25)$ & 8. $8(23)$ & $5.4(21)$ & 4. $5(17)$ \\
\hline L X試薬 ‘栄研” 試料 1 & - & - & 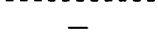 & 7.8 & 8.0 & $17.7(13)$ \\
\hline$\beta_{2}-\mathrm{M}-\mathrm{II}$ & - & - & 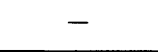 & $5.4 \quad(6)$ & 5.0 & 6. $4 \quad(13)$ \\
\hline フェリチンキット 試料1 & $23.8(20)$ & 18. $6(18)$ & 18. $4(19)$ & $5.3(15)$ & $5.1(10)$ & 9. 4 (11) \\
\hline 「第一」試料2 & $8.1(20)$ & $8.2(16)$ & 8. $7(18)$ & 4. $5(15)$ & 7. $2(11)$ & 6. $1(11)$ \\
\hline ケミルミAC S- 試料 1 & $23.5 \quad(7)$ & $30.6(10)$ & 15.8 (13) & $5.8(16)$ & $4.9(16)$ & $11.7(15)$ \\
\hline フェリチン 試料2 & $5.3 \quad(7)$ & 8. $2 \quad(9)$ & 4. $0(12)$ & $6.5(15)$ & $5.6(16)$ & 3. $6(14)$ \\
\hline プロリフィゲン＼cjkstart試料 1 & - & - & - & - & - & $5.5(10)$ \\
\hline N S Eキッ卜「第一」試料2 & - & - & - & - & - & 3. $4(10)$ \\
\hline
\end{tabular}

注 1 （）内は、統計処理対象キット数（N）。

注 2 今回のコントロールサーベイで使用されたキット数が10以上のもの。 
表12 キットの標準物質の違い

\begin{tabular}{|c|c|c|c|c|c|}
\hline 項 & 目 & 準拠するスタンダード & キ ッ & 備 & 考 \\
\hline \multirow[t]{2}{*}{ F S H } & & (1) WHO 2nd IRP $78 / 549$ & $\begin{array}{l}\text { スパック-S F S Hキット } \\
\text { アレグロ F S Hキット } \\
\text { リアグノスト F S H } \\
\text { アキシム F S H・ダイナパック } \\
\text { IMx F S H・ダイナパック } \\
\text { IMx-SELECT F S H ・ダイナパック } \\
\text { アマライト F S H } \\
\text { ビトロス F S H } \\
\text { オープス F S H } \\
\text { デルフィア F S H } \\
\text { コバスコア試薬 F S H-E I A } \\
\text { ルミノマスター F F S H」 } \\
\text { Eテスト 「T0SOH」 II. ～F S H) } \\
\text { エンチムンテスト F S H E C } \\
\text { D P C・イムライズ F S H } \\
\text { エクルーシス II F S H } \\
\text { セローノSR1 F S H } \\
\text { テクニコイムノ1 F S Hテスト }\end{array}$ & & \\
\hline & & (2) WHO 2nd IRP $94 / 632$ & ケミルミA C S - F S H & & \\
\hline \multirow[t]{2}{*}{$\mathrm{LH}$} & & (1) WHO 1st IRP $68 / 40$ & $\begin{array}{l}\text { スパック-S L Hキット } \\
\text { アレグロ L Hキット } \\
\text { リアグノスト L H } \\
\text { IMx LH・ダイナパック } \\
\text { IMx-SELECT L H・ダイナパック } \\
\text { アキシム L H ・ダイナパック } \\
\text { アマライトL H-30 } \\
\text { Eテスト 「TOSOH」 I （L H }) \\
\text { グラオザイム L H-(M) } \\
\text { D P C・イムライズ L H } \\
\text { セローノSR1 L H }\end{array}$ & & \\
\hline & & (2) WHO 2nd IRP $80 / 552$ & 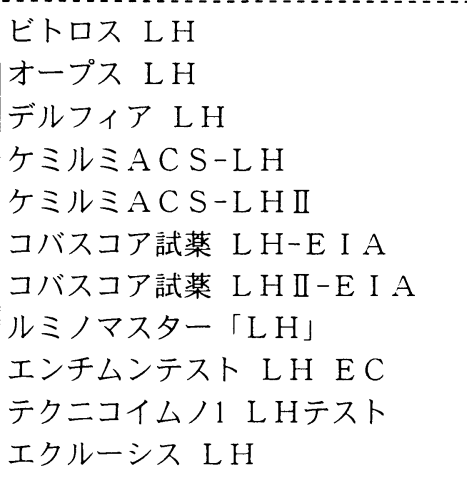 & & \\
\hline
\end{tabular}




\begin{tabular}{|c|c|c|c|}
\hline 項 & 準拠するスタンダード & キ ッ ト 名 & 備 \\
\hline \multirow[t]{4}{*}{ プロラクチン } & (1) $\mathrm{N}$ I H VLS \# 4 & プロラクチン・リアビーズ II & (2)でも読み取り可能 \\
\hline & (2) WHO 1 st IRP $75 / 504$ & $\begin{array}{l}\text { プロラクチンリアビーズ II (WH0) } \\
\text { スパック-S プロラクチンキット } \\
\text { アレグロProlactinキット } \\
\text { ガンマーダブプロラクチン }\end{array}$ & \\
\hline & (3) WHO 2nd IRP $83 / 562$ & $\begin{array}{l}\text { A b ビーズ プロラクチン ‘栄研’ } \\
\text { Eテスト「TOSOH」 I P R L } \\
\text { グラオザイム P R L-(M) } \\
\text { セローノSR1 P R L }\end{array}$ & (2)でも読み取り可能 \\
\hline & (4) WHO 3rd IRP $84 / 500$ & $\begin{array}{l}\text { D P C・プロラクチン-IRMAII キット } \\
\text { プロラクチン-I R M A テストコー } \\
\text { IMx プロラクチン・ダイナパック } \\
\text { IMx-SELECT プロラクチン・ダイナパック } \\
\text { アキシム プロラクチン・ダイナパック } \\
\text { アマライトプロラクチン-30 } \\
\text { デルフィアプロラクチン } \\
\text { ビトロスプロラクチン } \\
\text { コバスコア試薬Prolactin-E I A } \\
\text { ケミルミA C S-プロラクチン } \\
\text { ルミノマスター P R L 」 } \\
\text { エンチムンテスト P R L E C } \\
\text { D P C・イムライズ P R L } \\
\text { エクルーシスプロラクチン I } \\
\text { テクニコイムノ1 プロラクチンテスト }\end{array}$ & \\
\hline
\end{tabular}

